THE SEEDS OF DIVERGENCE: THE ECONOMY OF FRENCH NORTH AMERICA, 1688 TO 1760

by

Vincent Geloso

B.S (Economics and Politics - Université de Montréal) 2009

M.Sc (Economic History - London School of Economics and Political Science) 2010

A dissertation submitted in partial satisfaction of the

requirements for the degree of

Doctor of Philosophy

in

ECONOMIC HISTORY

in the

DEPARTMENT OF ECONOMIC HISTORY

of the

LONDON SCHOOL OF ECONOMICS AND POLITICAL SCIENCE

OCTOBER 2016 


\section{SEEDS OF DIVERGENCE: THE ECONOMY OF FRENCH NORTH AMERICA, 1688 TO 1760}

ABSTRACT: Generally, Canada has been ignored in the literature on the colonial origins of divergence with most of the attention going to the United States. Late nineteenth century estimates of income per capita show that Canada was relatively poorer than the United States and that within Canada, the French and Catholic population of Quebec was considerably poorer. Was this gap long standing? Some evidence has been advanced for earlier periods, but it is quite limited and not well-suited for comparison with other societies.

This thesis aims to contribute both to Canadian economic history and to comparative work on inequality across nations during the early modern period. With the use of novel prices and wages from Quebec — which was then the largest settlement in Canada and under French rule — a price index, a series of real wages and a measurement of Gross Domestic Product (GDP) are constructed. They are used to shed light both on the course of economic development until the French were defeated by the British in 1760 and on standards of living in that colony relative to the mother country, France, as well as the American colonies.

The work is divided into three components. The first component relates to the construction of a price index. The absence of such an index has been a thorn in the side of Canadian historians as it has limited the ability of historians to obtain real values of wages, output and living standards. This index shows that prices did not follow any trend and remained at a stable level. However, there were episodes of wide swings - mostly due to wars and the monetary experiment of playing card money. The creation of this index lays the foundation of the next component.

The second component constructs a standardized real wage series in the form of welfare ratios (a consumption basket divided by nominal wage rate multiplied by length of work year) to compare Canada with France, England and Colonial America. Two measures are derived. The first relies on a "bare bones" definition of consumption with a large share of land-intensive goods. This measure indicates that Canada was poorer than England and Colonial America and not appreciably richer than France. However, this measure overestimates the relative position of Canada to the Old World because of the strong presence of land-intensive goods. A second measure is created using a "respectable" definition of consumption in which the basket includes a larger share of manufactured goods and capital-intensive goods. This second basket better reflects differences in 
living standards since the abundance of land in Canada (and Colonial America) made it easy to achieve bare subsistence, but the scarcity of capital and skilled labor made the consumption of luxuries and manufactured goods (clothing, lighting, imported goods) highly expensive. With this measure, the advantage of New France over France evaporates and turns slightly negative. In comparison with Britain and Colonial America, the gap widens appreciably. This element is the most important for future research. By showing a reversal because of a shift to a different type of basket, it shows that Old World and New World comparisons are very sensitive to how we measure the cost of living. Furthermore, there are no sustained improvements in living standards over the period regardless of the measure used. Gaps in living standards observed later in the nineteenth century existed as far back as the seventeenth century. In a wider American perspective that includes the Spanish colonies, Canada fares better.

The third component computes a new series for Gross Domestic Product (GDP). This is to avoid problems associated with using real wages in the form of welfare ratios which assume a constant labor supply. This assumption is hard to defend in the case of Colonial Canada as there were many signs of increasing industriousness during the eighteenth and nineteenth centuries. The GDP series suggest no long-run trend in living standards (from 1688 to circa 1765). The long peace era of 1713 to 1740 was marked by modest economic growth which offset a steady decline that had started in 1688, but by 1760 (as a result of constant warfare) living standards had sunk below their 1688 levels. These developments are accompanied by observations that suggest that other indicators of living standard declined. The flat-lining of incomes is accompanied by substantial increases in the amount of time worked, rising mortality and rising infant mortality. In addition, comparisons of incomes with the American colonies confirm the results obtained with wagesCanada was considerably poorer.

At the end, a long conclusion is provides an exploratory discussion of why Canada would have diverged early on. In structural terms, it is argued that the French colony was plagued by the problem of a small population which prohibited the existence of scale effects. In combination with the fact that it was dispersed throughout the territory, the small population of New France limited the scope for specialization and economies of scale. However, this problem was in part created, and in part aggravated, by institutional factors like seigneurial tenure. The colonial origins of French America's divergence from the rest of North America are thus partly institutional.

NOTE 1: Four appendixes provide a full discussion of the data collected

NOTE 2: In this dissertation, I will use the words "Canada", "Quebec" and "New France" interchangeably to refer to the same area which is the basin of French settlements alongside the banks of the St-Lawrence River. 


\section{ACKNOWLEDGEMENTS}

In the redaction of this document, three fellow graduate students have constantly supported me in improving my own research. Vadim Kufenko of Hoheinheim University has helped me considerably with the wage data and has become a tremendously pleasant research partner and friend. Youcef Msaid has also been a great discussion partner past whom I could run my ideas. Julien Gagnon from the University of Cambridge has also provided important insights. At the London School of Economics, the helpful comments of Edward Kerby, Katja Fuder, Pinar Ceylan, Judy Stephenson and Gerardo Serra allowed me on many occasions to avoid continuing on wrong tracks.

Some professors require important acknowledgements. The first is my close friend, mentor and constant supporter Germain Belzile of HEC Montreal who has been a tremendous help in validating (and invalidating) some of my ideas and who provided numerous other ideas to extend and complete my work. The second is Gilles Paquet of the University of Ottawa. As the foremost economic historian on early Canada, Mr. Paquet pointed me in the right direction on many occasions and shared his works, allowing me to pick up where he left off. Moreover, he has allowed me to prepare a research agenda on Canadian economic history that may sustain me for many years. My two supervisors, Chris Minns and Stephen Broadberry have also been very helpful in the production of this work. Their respective expertise helped me avoid many pitfalls and wrong starts. Professors Jeffrey Williamson and Peter Lindert have provided very insightful comments in the late stages of my research. I kept this dissertation's aims modest in order to avoid tackling more than I could handle. However, both professors persuaded me to organize the data collected here in order to extend my research to the issues of price volatility, international trade, market integration, demography and its impact on labor force participation, and urban-rural relations. This, I hope, will occupy the next few years of my career. In addition, Michael Huberman of the University of Montreal, Catherine Desbarats of McGill University and Jari Eloranta of Appalachian State University have been very supportive in my endeavours. The comments of these individuals have allowed me to focus more precisely on what mattered and on how to build robust research. Professors Jeffrey Williamson and Peter Lindert provided considerably helpful comments during the late stages of my research to bring it up to form.

The organizers of the conferences of the Canadian Economic History Network, the Economic History Society, the Economic History Association and the Economic and Business History Society, the Centre Interuniversitaire de Recherche Économique du Québec, Institute of Applied Economics at HEC Montréal and the department of Economics at Université du Québec à Montréal are also to be thanked for allowing me to present my papers to fellow academics in order to receive feedback. The Journal de Montréal also warrants acknowledgement. Through Michel Dumais, the Journal de Montréal hired me as an economics columnist while I was writing my thesis. Through 
this job, I was able to fund my research without resorting to government grants - something from which I derive great pride.

Special acknowledgements go to Alexandra Foucher, my kinder and quite patient better half, who generously supported me throughout the process of this thesis. My parents, Antoine and Danielle, have also been tremendously encouraging. 
Contents

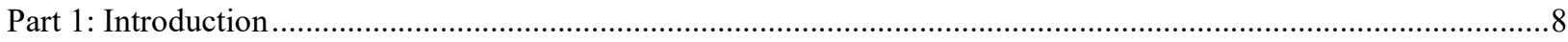

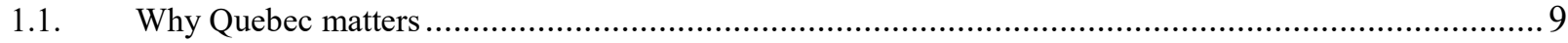

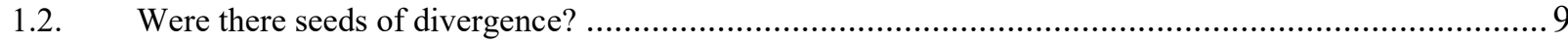

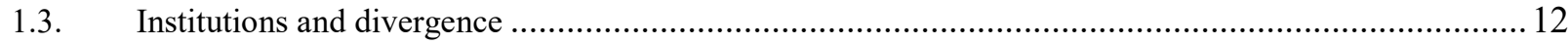

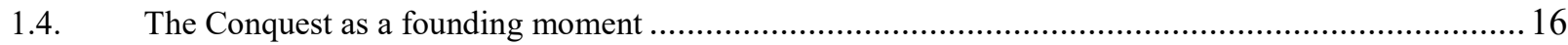

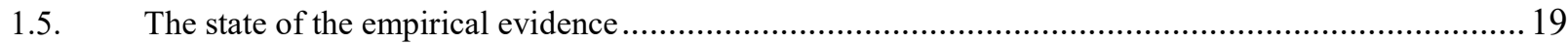

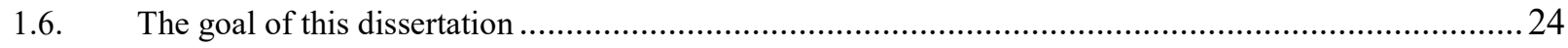

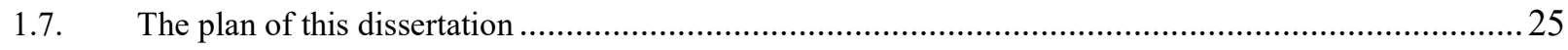

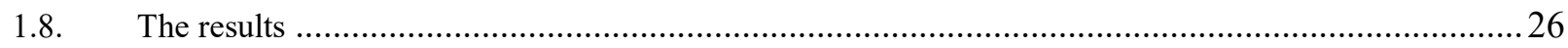

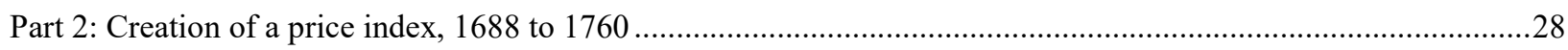

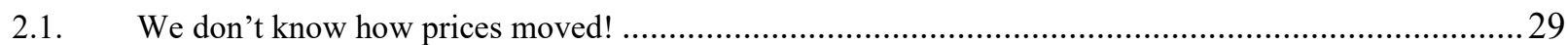

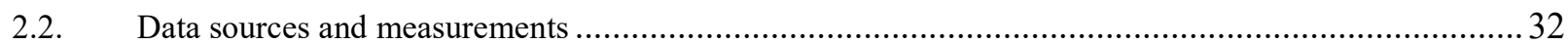

2.3. How do these prices compare with other prices collected? .................................................. 37

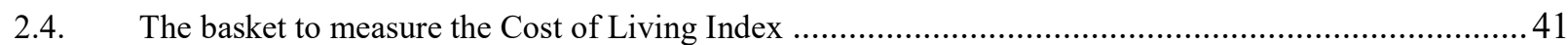

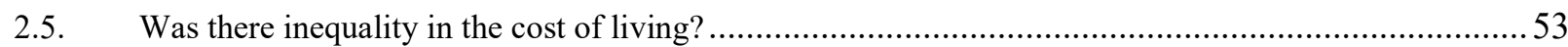

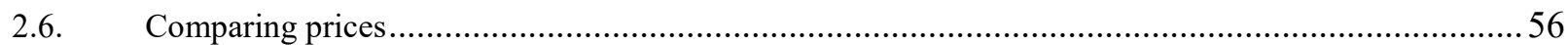

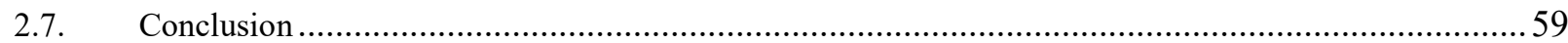

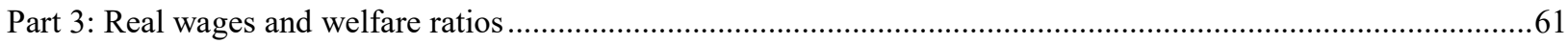

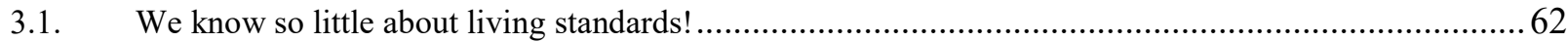

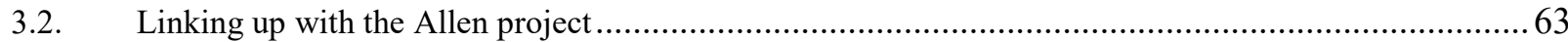

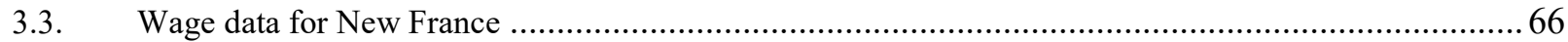

3.4. Constructing the basket of goods for the welfare ratios.................................................... 78

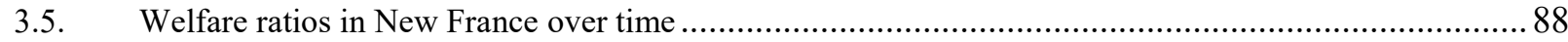

3.6. Welfare ratios comparison between France and New France............................................... 90

3.7. Welfare ratios comparison between the Colonial United States, England, Latin America and New France 100

3.8. Conclusion .................................................................................................. 110

Part 4: Real Gross Domestic Product and income per capita................................................................. 111

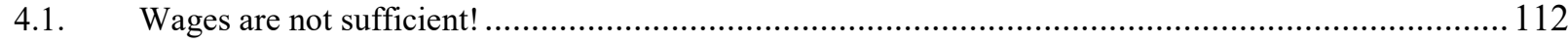

4.2. The limits of welfare ratios relevant to this work: weather, work year and family size ................... 112

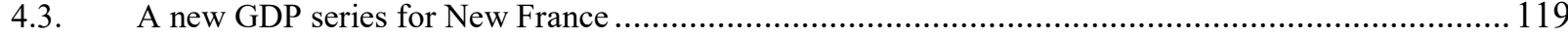

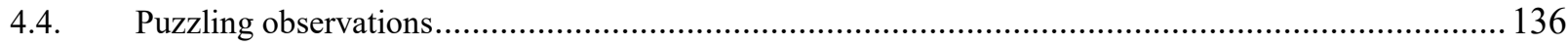

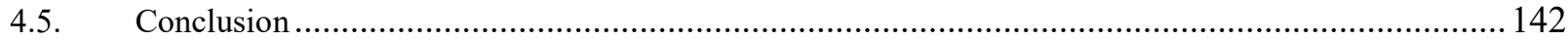




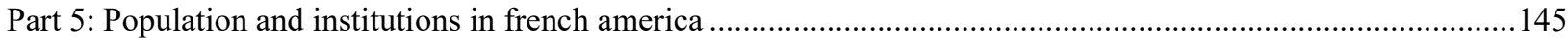

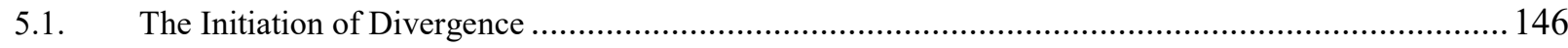

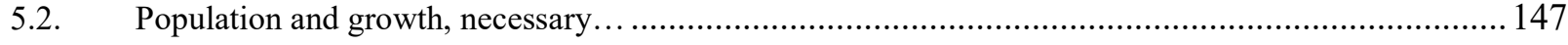

5.3. ...but insufficient without considering seigneurial tenure ....................................................... 155

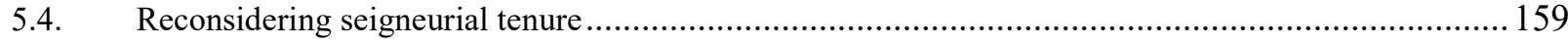

5.5. Evidence supporting the reconsideration of seigneurial tenure .................................................... 161

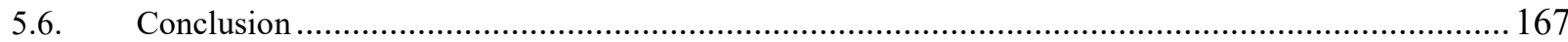

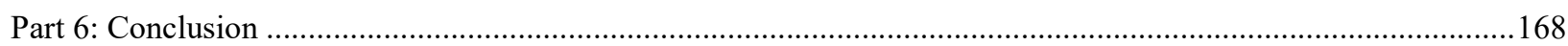

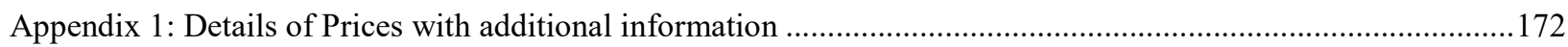

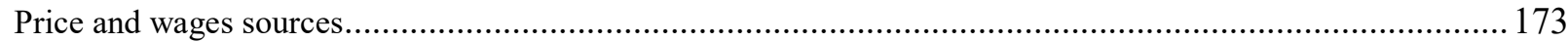

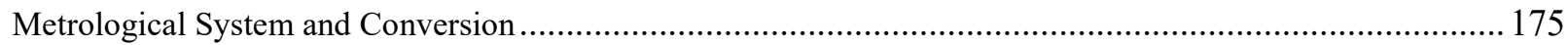

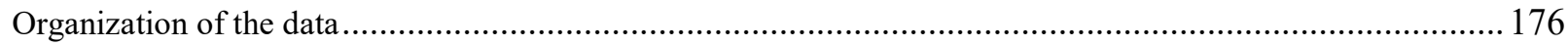

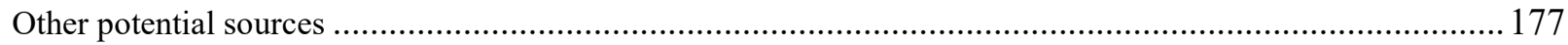

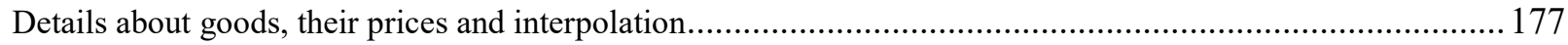

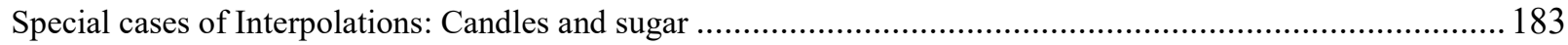

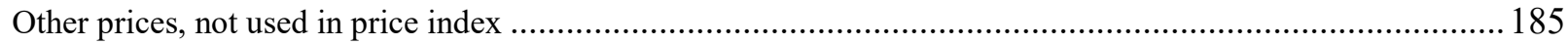

Appendix 2: Details of Wages with additional information ................................................................................198

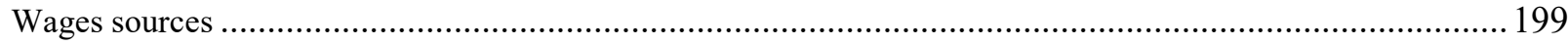

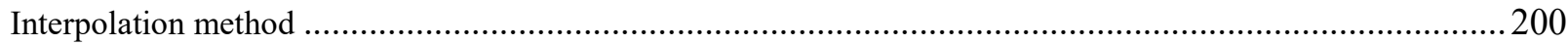

Appendix 3: Linking our prices to the paquet-wallot price index ........................................................................201

The Paquet-Wallot price index as a measure of the economy's movement..................................................202

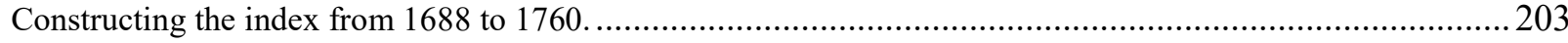

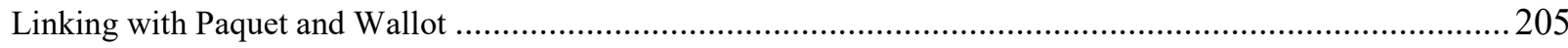

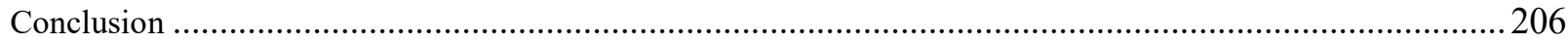

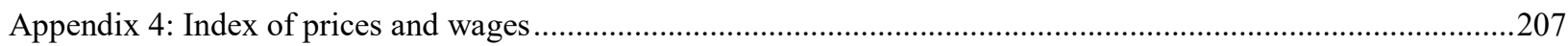

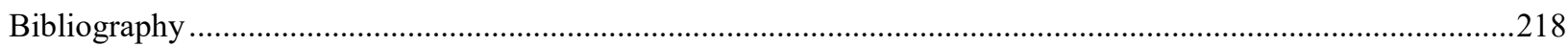




\section{PART 1: INTRODUCTION}




\subsection{Why Quebec matters}

What can Quebec's economic history tell us about modern economic history? The economic history of this French-speaking province in Canada with a predominantly catholic population is of crucial importance in order to better understand Canada's economic (and political) history in particular. Its relevance both to Canadian history and to Western economic history in general should not be underestimated.

The first reason is that its colonial roots are unique. As a French Catholic settlement colony in North America, it is indeed unique. Its institutions were markedly different from those found in colonial America. Yet, it also shared geographical similarities with places within New England in terms of the environmental constraints imposed on farming. Also like the American colonies, it was an economy with abundant lands relative to labour and capital. However, little is known about living standards prior to the nineteenth century and the limited evidence is not geared for comparison with other societies. Was it richer or poorer than the American colonies during the colonial era? Was it, like it is the case for the American colonies and the Spanish colonies, richer than its home country? ${ }^{1}$ Did it converge or diverge from experiences elsewhere? The answer is that we do not know. Yet, the peculiarities of its colonial origins are inviting.

The second reason is more straightforward: Quebec plays a major role in Canadian history. Although it was relatively poorer than the rest of $\mathrm{Canada}^{2}$, it was one of the initial four colonies that formed the Canadian confederation in 1867 and it formed the major bastion of the French presence in North America. A deep understanding of Quebec's economic history yields important implications for Canada's political and economic history.

\subsection{Were there seeds of divergence?}

The most interesting contribution of this research lies in the integration of Canada in the study of divergence, especially the colonial roots of this divergence. Thanks to a burst of empirical research since the 1960s, important datasets have emerged regarding the measurement of living standards across the Americas prior to the nineteenth century. The main pieces of evidence have

\footnotetext{
${ }^{1}$ Peter Lindert and Jeffrey Williamson. 2016. Unequal Gains: American Growth and Inequality since 1700. Princeton, NJ: Princeton University Press; Robert Allen, Tommy Murphy and Eric Schneider. 2012. "The Colonial Origins of the Divergence in the Americas: A Labor Market Approach", Journal of Economic History, Vol. 72, No. 4, pp.86394.

${ }^{2}$ I worked on the topic of Quebec's economic convergence within Canada between 1900 and 2010, see here: Vincent Geloso. 2013. Du Grand Rattrapage au Déclin Tranquille: Une Histoire Économique du Québec de 1900 à nos jours. Montréal: Éditions Accent Grave.
} 
relied on either anthropometric data through the heights of soldiers or convicts ${ }^{3}$, on controlled conjectures of Gross Domestic Product, ${ }^{4}$ or on real wages presented as welfare ratios. The welfare ratios approach is probably the most popular. Based on the World Bank's approach to measuring poverty, this tool has been imported into the economic history literature by Robert Allen in order to circumvent issues related to exchange rates. ${ }^{5}$ Given the limited variety of goods traded across regions (or across nations) prior to the nineteenth century, price levels might differ substantially across countries. ${ }^{6}$ Converting incomes, wages or prices into a common currency unit creates a false impression of differences in living standards. However, welfare ratios circumvent that issue by dividing incomes by the local costs of baskets of goods that resemble a poverty line estimate. They thus create a standardized measure of living standards that controls for purchasing power parities. ${ }^{7}$

This has led to a burgeoning literature in which there seems to be some agreement. Colonists tended to be better off than the inhabitants of the countries they had left. The American colonists were richer than the British according to both Robert Allen et al. ${ }^{8}$ who relied on welfare ratios based on wages, and the Lindert-Williamson duo who relied on welfare ratios based on incomes derived from a social tables approach. ${ }^{9}$ The inhabitants of Latin America also seemed to be faring relatively well when compared with Northwestern Europe according to Arroyo Abad et al. ${ }^{10}$ Overall, the New World seemed relatively well off compared with the Old World although the comparisons seem to be sensitive to the design of the basket of goods used for welfare ratios. Lindert and Williamson found that, when one switched to a respectable basket that included more

\footnotetext{
${ }^{3}$ Rafael Dobado-Gonzalez and Héctor García-Montero 2014. "Neither So Low Nor So Short: Wages and Heights in Bourbon Spanish America from an International Comparative Perspective," Journal of Latin American Studies, Vol.46, no.2, pp.291-321; Nancy Tatarek. 2006. "Geographical height variation among Ohio Caucasian male convicts born 1780-1849," Economics \& Human Biology, Vol.4, no.2, pp.222-236.

${ }^{4}$ Angus Maddison. 2003. The World Economy: Historical Statistics. Paris: Organisation for Economic Cooperation and Development; Paul David. 1967. "New light on a statistical dark age: US real product growth before 1840", American Economic Review, Vol. 57, no.2, pp.294-306; Peter Mancall and Thomas Weiss. 1999. "Was Economic Growth Likely in Colonial British North America" Journal of Economic History, Vol.59, no.1 p.17-40.

${ }^{5}$ Robert C.Allen. 2001. "The great divergence in European wages and prices from the Middle Ages to the First World War" Explorations in economic history, Vol.38, No.4, pp.411-447.

${ }^{6}$ Bela Balassa. 1964. "The Purchasing-Power Parity Doctrine: A Reappraisal”, Journal of Political Economy, Vol. 72 , no.6, pp.584-596.

${ }^{7}$ It is worth pointing out that there are attempts predate those of Allen. Citing the work of Fernand Braudel and Jan Luiten van Zanden, Kenneth Pommeranz relied extensively on grain-wages to calculate differences in living standards (i.e. wages measured as the quantity of grains acquired in a day's work): Kenneth Pomeranz. 2000. The Great Divergence: China, Europe, and the Making of the Modern World Economy. Princeton, NJ: Princeton University Press.

${ }^{8}$ Robert Allen, Tommy Murphy and Eric Schneider. 2012. "The Colonial Origins of the Divergence in the Americas: A Labor Market Approach", Journal of Economic History, Vol. 72, No. 4, pp.863-94.

${ }^{9}$ Peter Lindert and Jeffrey Williamson. 2016. Unequal Gains: American Growth and Inequality since 1700. Princeton, NJ: Princeton University Press

${ }^{10}$ Leticia Arroyo Abad, Elwyn Davies and Jan Luiten van Zanden. 2012. "Between conquest and independence: real wages and demographic change in Spanish America, 1530-1820”, Explorations in Economic History, Vol.49, no.2, pp.149-166.
} 
manufactured and imported goods, a part of the advantage of the British colonies over Britain melted away. ${ }^{11}$ Within the Americas, there were wide differences-even within colonial groupings. Arroyo Abad et al. and Allen et al. found that while all the Spanish colonies fared worse than the British colonies, some of them were doing better than others. For example, between 1725 and 1774, Peru had a welfare ratio reaching only 1.18 (meaning that the wages for 250 days bought only 1.18 times the basket of goods for a typical family) while Bolivia and Mexico had ratios of 2.95 and 2.99. ${ }^{12}$ Within the American colonies, basing themselves on incomes derived from social tables (welfare ratios based on incomes are lower than those based on wages because of differences in labor participation), Lindert and Williamson found that in 1750, Bostonians enjoyed welfare ratios of 7.5 while the same figure stood at 18.5 for the Lower South and at 10.1 for the thirteen colonies as a whole (they calculated in a bundle for one person without adjusting for household size). ${ }^{13}$ Finally, all the colonies — regardless of whether they were British or Spanish — seem to have enjoyed no growth over time. ${ }^{14}$

Conspicuously absent from all this are the French and Canada. While the French had important holdings in the Caribbean - notably Haiti and the sugar islands of Martinique and Guadeloupe - their largest holding outside of that region was in modern-day Quebec. Originally settled for the purposes of developing the fur trade, Quebec progressively became a settlement colony in which agriculture and other, non-fur, industries would emerge. Although migration to Canada was mostly coerced, its population swelled rapidly to reach close to sixty thousand by 1760. ${ }^{15}$ This was by no means the largest colony in North America, but it was sizable and it ought to be mentioned that slavery played only a trivial role in its development. ${ }^{16}$

The absence of Canada from the comparisons is unfortunate. This absence can easily be explained by a lack of data or, more precisely, a lack of usable data. In the late nineteenth century,

\footnotetext{
11 Peter Lindert and Jeffrey Williamson. 2016. Unequal Gains: American Growth and Inequality since 1700. Princeton, NJ: Princeton University Press, pp.73-74. Note: At the bare bones level, the thirteen colonies are 53\% richer than Great Britain while Bostonians were 14\% richer than their English counterparts.

${ }^{12}$ Leticia Arroyo Abad, Elwyn Davies and Jan Luiten van Zanden. 2012. "Between conquest and independence: real wages and demographic change in Spanish America, 1530-1820", Explorations in Economic History, Vol.49, no.2, p.158.

${ }_{13}$ Peter Lindert and Jeffrey Williamson. 2016. Unequal Gains: American Growth and Inequality since 1700. Princeton, NJ: Princeton University Press, p.63-64

${ }^{14}$ This is still impressive, especially for the American colonies, given the rapid rate of population growth.

${ }^{15}$ Peter Moogk. 1989. "Reluctant Exiles: Emigrants from France in Canada before 1760", William \& Mary Quarterly, Vol.46, No.3, pp.463-505.

${ }^{16}$ To be sure, slavery did exist in Canada. However, as historian Marcel Trudel pointed out, there were fewer than 5,000 slaves in Quebec from the mid-seventeenth century to 1834. Only a quarter of them were Africans, the others were Natives Americans (Panis). Overall, fewer than 400 slaves arrived in Quebec from 1700 to 1759. These numbers suggest that its role as an institution was quite limited (Marcel Trudel. 2004. Deux siècles d'esclavage au Québec. Montréal : Hurtubise).
} 
Canada as a whole appeared poorer than the United States, ${ }^{17}$ and Quebec in particular seemed even poorer. ${ }^{18}$ In fact, even within Canada it was poorer than the rest during the late nineteenth century. ${ }^{19}$

Was this a long standing fact? Was Quebec poorer from the very beginning or was this something that emerged prior to the first reliable measurements? Was there any economic growth during the colonial era? And, given that most of Quebec's initial settlers can only be characterized as "reluctant," were living standards in Quebec higher than in the mother country of France? Are the general observations made for the other colonies applicable to the French colony? The answer to all these questions is elusive because of the absence of data.

Before we proceed to explain the state of the data, it is worth underlining the relevance of trying to fill in this absence. There are two reasons for this. The first relates to the similarities between Canada and the United States and the insights that could be gained regarding its development. The second relates to providing the first step in answering a crucial answer in Canadian political and economic history.

\subsection{Institutions and divergence}

In 2013, Peter Lindert and Jeffrey Williamson pointed to a need for "fresh information" on regarding income levels in the British North American colonies at the dawn of the revolution. ${ }^{20}$ The existing estimates of economic growth enjoyed by the United States did not permit with certainty assertions on whether or not the colonies experienced real growth. Some authors, like Thomas Weiss and Peter Mancall are skeptical about the likelihood of positive and strong economic growth (so were Lindert and Williamson). ${ }^{21}$ The American economy merely expanded at the rate to which inputs increased, Williamson and Lindert have supported this claim of poor growth, but they added that although growth was slow, the level of income was actually higher

\footnotetext{
${ }^{17}$ Morris Altman. 2003. "Staple theory and export-led growth: constructing differential growth", Australian Economic History Review, Vol.43, No.3, pp.230-255

${ }^{18}$ Kris Inwood and Jim Irwin. 2002. "Land, income and regional inequality: New estimates of provincial incomes and growth in Canada, 1871-1891", Acadiensis, Vol.31, no.2, pp.157-184.

${ }^{19}$ Edward Chambers and Donald Gordon. 1966. "Primary products and economic growth: an empirical measurement" Journal of Political Economy, Vol. 74, no.4, pp.315-332; Morris Altman. 1988. "Economic development with high wages: an historical perspective", Explorations in Economic History, Vol.25, no.2, pp.198-224.; Alan Green. 1969. "Regional Inequality, Structural Change, and Economic Growth in Canada. 1890-1956", Economic Development and Cultural Change, Vol.17, no.4, pp.567-583; Cole Harris. 2012. Le Pays Revêche: Société, espace et environnement au Canada avant la Confédération. Québec : Les Presses de l'Université Laval.

${ }^{20}$ Jeffrey Williamson and Peter H.Lindert. 2013. "American Incomes Before and After the Revolution”, Journal of Economic History, Vol.73, No.3, p.725.

${ }^{21}$ Peter Mancall and Thomas Weiss. 1999. "Was Economic Growth Likely in Colonial British North America" Journal of Economic History, Vol.59, no.1 p.17-40.
} 
than it was in Britain. ${ }^{22}$ Others, like Marc Egnal ${ }^{23}$ and Alice Jones ${ }^{24}$, have claimed that growth was positive and appreciably high for the time (between $0.4 \%$ and $0.6 \%$ per annum). Both sides concur that this disagreement does not negate the fact that American economic performance was exceptional. As Mancall and Weiss put it:

The colonial economy nevertheless performed well in an aggregate sense. This is a well-known story, but perhaps one worth recalling. Total output grew at healthy rates reflecting the fact that the economy was able to absorb large numbers of people without suffering any setbacks. As mundane as this sounds, it is a notable accomplishment, especially in light of the numerous less-developed economies that have failed to do so. Moreover, even though output per capita may have been stagnant, there were still opportunities to be had. The colonies were a land of promise, at least for European settlers; the average standard of living may not have been improving, but it remained high enough to continue to attract migrants. ${ }^{25}$

It is hard to see why Quebec would not fit into this story. Like the American colonies, it was a frontier economy where land was abundant and labor was scarce. While migration flows were smaller in New France than in the American colonies, it was recognized by contemporaries that those who migrated to New France enjoyed greater living standards. For example, Pehr Kalm, a Swedish naturalist who visited the colony in the late 1740s and left a very extensive account of his voyage, described the diets of French Canadians as such: "French-Canadian meals, if I may say so, are usually overabundant; they are served numerous dishes: soups as well as a variety of meat (...)" ${ }^{26}$ Other contemporaries, when visiting New France, were also surprised at the high standard of living of the French Canadians relative to those enjoyed by French speakers on the old continent. Yet, one should be careful with such quotes. This quote by Kalm is often repeated, but seldom is it mentioned that he was referring to members of a religious congregation - hardly the median individuals in a society. Nonetheless, the general belief is that French Canadians enjoyed a relatively high living standard. ${ }^{27}$ It is possible that the inhabitants of New France, like those of

\footnotetext{
22 Peter Lindert and Jeffrey Williamson. 2014. American Colonial Incomes, 1650-1774. Cambridge, MA: National Bureau of Economic Research. Note: New England has positive growth while the South has negative growth

${ }^{23}$ Marc Egnal. 1998. New World Economies: The Growth of the Thirteen Colonies and Early Canada. Oxford: Oxford University Press.

${ }^{24}$ Alice Hanson Jones 1980. Wealth of a Nation to Be. New York: Columbia University Press.

25 Peter Mancall and Thomas Weiss. 1999. "Was Economic Growth Likely in Colonial British North America" Journal of Economic History, Vol.59, no.1 p.19.

${ }^{26}$ Quoted in in Paul-Louis Martin. 2002. Les Fruits du Québec: histoire et traditions des douceurs de la table. Montréal : Éditions Septentrion, p.49.

${ }^{27}$ Marc Egnal. 1996. Divergent Paths: How Culture and Institutions have shaped North American Growth. Oxford: Oxford University Press; Marc Egnal. 1998. New World Economies: The Growth of the Thirteen Colonies and Early Canada. Oxford: Oxford University Press; Cameron Nish. 1968. Les bourgeois-gentilshommes de la NouvelleFrance, 1729-1748. Montréal: Fides; Jacques Girard. 1959. "Les industries de transformation de la NouvelleFrance", Cahiers de géographie du Québec, Vol.3, no.6, pp.305-320.
} 
New England compared with England, were richer than their counterparts in France. However, we cannot know as this has never been measured.

Of greater relevance is the comparison between New England and the colonists in Quebec. With the exception of the institutions installed in both sets of colonies, these are remarkably similar cases which have not been compared. They are geographically close and share climatic similarities. This is not to say that they are identical. Their similarities are far greater than those found with Southern states, let alone Latin America. The similarities go beyond the environment. Both their economies were structured on a small minority trading staple goods ${ }^{28}$ with the mother country, and the vast majority working as farmers in a countryside which was poorly suited to farming.

The largest difference between the two is institutional. The French colonial administration imported the French seigneurial system to the colony while the Americans operated under freehold tenure. Given that Canada was a frontier economy with abundant land, the institution of seigneurial tenure could have simply boosted the bargaining power of landlords (seigneurs) relative to peasants. Indeed, the system was designed to impose de jure (prohibitions on leaving their farms) and de facto (taxes on the sale of land) limitations to mobility. With limited mobility, the seigneurs imposed a series of duties that, while light under French rule, progressively increased as the population of the colony increased..$^{29}$ Furthermore, the seigneur also monopoly rights over milling and could legally tax any industrial activity on his estate (fixed land-related duties and a capital transfer tax equal to $1 / 12^{\text {th }}$ of the sale price). This is considerably different from the American colonies to the south of Quebec.

In fact, it is because institutions were the single largest difference that Quebec makes an interesting comparison point. That institutions impact economic development is well admitted, but how these institutions have come to matter and differ across space and time is still subject to significant debate. More importantly, there has been a rising literature on the role of colonial origins. On the one hand, Acemoglu, Johnson and Robinson argued that the mortality of settlers at the beginning of settlement determined the type of institutions European settlers wanted to establish. ${ }^{30}$ Higher mortality meant that Europeans opted to establish extractive institutions that would tend to depress long-term growth while lower mortality incentivized the construction of institutions that enshrined property rights and fostered growth. ${ }^{31}$ On the other hand, this particular

\footnotetext{
${ }^{28}$ However, it is worth indicating that Quebec's trade sector was substantially larger than that of the American colonies up to the $1770 \mathrm{~s}$, although it was declining progressively. This is discussed in greater detail below.

${ }^{29}$ Fernand Ouellet.1972. Élements d'histoire sociale du Bas-Canada. Montréal : Hurtubise HMH.

${ }^{30}$ Daron Acemoglu, Simon Johnson and James Robinson. 1999. "The Colonial Origins of Comparative Development: An Empirical Investigation”, American Economic Review, Vol.91, No.5, pp.1369-1401.

${ }^{31}$ A good survey of the theoretical discussion can be found in Daron Acemoglu, Simon Johnson and James Robinson. 2005. "Institutions as a fundamental cause of long-run growth" in eds. Philippe Aghion and Steven Durlauf, Handbook of Economic Growth, Vol 1A. New York, NY: North Holland, pp. 386-464.
} 
theory has been subjected to important theoretical and empirical criticism. The largest empirical criticisms have been submitted by David Albouy who demonstrated the presence of numerous coding errors, non-robust statistical methods and arbitrary methodological choices which invalidated this main empirical claim of Acemoglu, Johnson and Robinson's paper. ${ }^{32}$ Sheilagh Ogilvie and A.W. Carus have also aimed substantial criticisms at their empirical findings, pointing out that institutions are more complicated and not prone to the generalizations made by Aceomoglu, Johnson and Robinson. ${ }^{33}$ It has also been pointed out that the impact of geographical endowments might mask initial differences in prosperity (and factor endowments) and thus the future path of economic growth. ${ }^{34}$ Since the geographical differences between the French colony of Quebec and the British colonies in North America were arguably minimal, this offers a rich case study in that the situation represents the equivalent of an experiment whereby the institutional variable is somewhat isolated.

Some historians have pointed out the potential of using Canada in studies of divergence. In 2006, the financial historian Richard Sylla argued that American historians have inexplicably avoided comparing Canada and the United States. Yet, in his own survey of financial intermediation in both countries in the first half of the nineteenth century, Sylla points out that a significant part of America's appreciable economic growth can be attributed to the development of financial intermediaries which did not develop as rapidly and robustly in Canada even though the two economies were structurally similar (with agriculture being the largest sector by far). ${ }^{35}$ In fact, the US-Canada comparisons have been pretty much limited to the realm of financial institutions. ${ }^{36}$ The only paper that has attempted to estimate economic growth in New France, that of Morris Altman, has only been quoted on seven occasions and three of those are self-cites. However, it is worth pointing out that Angus Maddison relied partially on Altman's estimates to attempt his approximations of Canadian GDP prior to $1870 .{ }^{37}$

\footnotetext{
${ }^{32}$ David Albouy. 2012. "The Colonial Origins of Comparative Development: An Empirical Investigation: Comment" American Economic Review, Vol.102, no.6, pp.3059-3076.

${ }^{33}$ Sheilagh Ogilvie and A.W. Carus. 2014. "Institutions and Economic Growth in Historical Perspectives", in eds Philippe Aghion and Steven Durlauf, Handbook of Economic Growth, Vol 2A. New York, NY: North Holland, pp. 403-513.

${ }^{34}$ Raphael A. Auer. 2013. "Geography, institutions, and the making of comparative development", Journal of Economic Growth, Vol.18, No.2, pp.179-215; Stanley Engerman and Kenneth Sokoloff. 2002. Factor Endowments, Inequality, and Paths of Development among New World Economics. Cambridge, MA: National Bureau of Economic Research.

${ }^{35}$ Richard Sylla. 2006. "Political Economy of Financial Development: Canada and the United States in the Mirror of the Other, 1790-1840.” Enterprise and Society, Vol. 7, no. 4, pp. 653-665.

${ }^{36}$ Michael Bordo, Angela Redish and Hugh Rockoff. 2015. "Why didn't Canada have a banking crisis in 2008 (or in 1930, or 1907, or ...)?" Economic History Review, Vol.68, no.1, pp.218-243; George Selgin. 2010. "Central banks as sources of financial instability", Independent Review, Vol.14, no.4, pp.485-496; George Selgin, William D. Lastrapes and Lawrence H. White. 2012. "Has the Fed been a failure", Journal of Macroeconomics, Vol.34, no.3, pp.569-596. ${ }^{37}$ Angus Maddison. 2003. The World Economy: Historical Statistics. Paris: Organisation for Economic Cooperation and Development, p.75.
} 
Providing an estimate of the economic growth of Quebec would allow us to see how the two sets of frontier economies were behaving. If both were growing at similar rates and expressed similar levels of income, one could reasonably infer that at that point in time, the role of institutions would have been small. If they were growing at different rates while incomes were different, then one could infer a greater role for institutions. This research will not directly attempt to deal with the importance of institutions in explaining differences (or similarities) between the two economies. However, providing any form of broad empirical estimate would allow future researchers to circumscribe their research by acting as a guiding light over the issues.

In addition, this dissertation will consider an important issue raised by many Peter Linder and Jeffrey Williamson in their work. They point out that when they used a different basket - one that included more manufactured goods as opposed to one including more land-intensive goods like food - as the price deflator for incomes and wages, a significant part of the advantage of the New World over the Old World evaporated. Since the New World can be characterized as a frontier economy, it had very different relative factor scarcities than the Old World (i.e. a high land to labor ratio as opposed to high labor to land ratio). The price deflators used in general have relied on large quantities of food items that would have been cheap in the unsettled New World. However, New World settlers had to face higher prices for manufactured goods, services and capitalintensive goods. The price deflators rarely account for this. ${ }^{38}$ As a result, comparisons might be biased and overstate the advantage of the New World over the Old World.

\subsection{The Conquest as a founding moment}

The invasion of Quebec by the British in 1760 (known as la Conquête, i.e. the Conquest), is a watershed moment in the history of Quebec and Canada. Its implications are hotly debated, especially with regard to the economic history of the province. Modern political debates regarding Quebec's possible separation from Canada rarely exclude references to the Conquest. Numerous interpretations exist around this event, all of which are supported by limited empirical evidence. However, there are high returns to providing evidence in this debate. Just as the debates over the "starting point" and the "causes" of the British industrial revolution represent a sort of Holy Grail in the field of economic history, the Conquest of Quebec represents the Holy Grail of the field of Canadian history.

\footnotetext{
38 Peter Lindert. 2016. Purchasing Power Disparity Before 1914. Cambridge, MA: National Bureau of Economic Research.
} 
Authors of the "nationalist" and "neonationalist" schools such as Lionel Groulx, ${ }^{39}$ Maurice Séguin ${ }^{40}$, and Guy Frégault ${ }^{41}$ tended to believe that once the British took over the colony, they "decapitated" the bourgeoisie of New France (as it was known before the Conquest). With that decapitation, made along ethnic lines, the population of Quebec lost from the Conquest as it ended the rise of an indigenous entrepreneurial spirit. Hence, the roots of Quebec's disappointing economic performance took hold in part at the time of the Conquest. ${ }^{42}$ The economist Marc Egnal has relied in great part upon that literature to make his claim that culture partly explained the economic decline of Quebec relative to the northern part of the United States and relative to the neighbouring British colonies. ${ }^{43}$ Popular historians, sociologists and nationalist intellectuals in Quebec such as Jacques Lacoursière, Denis Vaugeois, Éric Bédard and Mathieu Bock-Côté have continued to convey this broadly defined view that the Conquest had negative effects. ${ }^{44}$ It is also still very much part of the political discourse regarding the place of Quebec within the federation.

Authors less in line with these schools of historiography have been less unified in their assessment of how the Conquest mattered less than believed. The first, Fernand Ouellet, asserted that the Conquest did not change the economic structure of the colony in any significant way. In fact, he believed that on the whole the Conquest had been beneficial. In his eyes, the decline of Quebec's economic fortunes which he perceived in the early nineteenth century took place as a result of the inherently conservative nature of the peasantry which was slow to adopt new technological implements into agriculture and industry. That form of behaviour had existed prior to the Conquest and continued thereafter, the change of regime having little bearing. The noted historian Louise Dechêne argued fundamentally in the same direction when she noted the persistence of French institutions — both formal and informal—after the Conquest. ${ }^{45}$

\footnotetext{
${ }^{39}$ Lionel Groulx. 1958. Notre Grande Aventure: l'empire Français en Amérique du Nord, 1535-1760. Montréal: Éditions Fides.

${ }^{40}$ Maurice Séguin. 1971 [1946]. "La conquête et la vie économique des Canadiens" in eds. René Durocher and PaulAndré Linteau, Le "Retard » du Québec et l'infériorité économique des Canadiens-Français. Montréal : Éditions Boréal Express, pp.93-111.

${ }^{41}$ Guy Frégault. 1969 [1990]. La civilisation de la Nouvelle-France, 1713-1744. Montréal : Éditions Fides

${ }^{42}$ I wish to emphasize the "in part" of this sentence, as none of the nationalist authors takes the view that the Conquest explains everything, merely that it is has a large influence on future developments.

${ }^{43}$ Marc Egnal. 1996. Divergent Paths: How Culture and Institutions have shaped North American Growth. Oxford: Oxford University Press.

${ }^{44}$ For a discussion of the two first authors' points, see Brian Young. 2012. "Below the Academic Radar: Denis Vaugeois and Constructing the Conquest in the Quebec Popular Imagination" in eds. Phillip Bucker and John G.Reid, Remembering 1759: The Conquest of Canada in Historical Memory. Toronto: University of Toronto Press, pp.226250. For the latter, one should consult Éric Bédard.2012. L'histoire du Québec pour les nuls. Montréal: First Editions, ${ }^{45}$ In his 2012 essay, Brian Young summarizes very succinctly how this group of historians diverges greatly from the aforementioned group of nationalist historians. Brian Young. 2012. "Below the Academic Radar: Denis Vaugeois and Constructing the Conquest in the Quebec Popular Imagination" in eds. Phillip Bucker and John G.Reid, Remembering 1759: The Conquest of Canada in Historical Memory. Toronto: University of Toronto Press, pp.226-250.
} 
Another group of historians, dominated by Gérald Bernier and Denis Monière, used a Marxian frame of analysis to assert that the Conquest introduced a "capitalist mode of production" into an economy which had been dominated by a more "local mode of production". ${ }^{46}$ The introduction of capitalism in Quebec changed economic structures and led to positive modernization. A third group, headed mainly by Gilles Paquet and Jean-Pierre Wallot, believes that the effect of the Conquest might have been positive but by accident. ${ }^{47}$ In their opinion, it was not thanks to a deliberate design on the part of the British that the colony benefitted but rather because access to the British market created (both for wheat and for timber), allowed greater scope for specialization within the economy of Quebec which progressively modernized. In their eyes, the Conquest was a positive development.

For decades, these groups have gone back and forth and convincing explanations and storylines have thus been elusive. In 2012, a few years after the $300^{\text {th }}$ anniversary of the battles of the Plains of Abraham which sealed the fate of New France, two compendiums of essays on the issue of the Conquest edited by Phillip Buckner and John Reid were published. These essays attempted to illustrate the wide discrepancies in opinion both within the academic community and between the academic community and the popular conception of the Conquest. In one of those essays, legal historian Donald Fyson pointed out that from 1989 to 2008, only "ten theses" were published on the issue of the regime change "most of which dealt only in part with the period". 48 The causes of this reticence, says Fyson, are twofold: the politicization of the topic within the popular imagination and the fact that the subject has "already been done to death." However, that the topic has been treated by many does not mean that it is settled. Selecting some common misconceptions among both the academic community and the general public, Fyson delivers the following indictment which explains well the elusiveness of a resolution to the issue:

\footnotetext{
46 This is the viewpoint I find the least well-argued among those who tend to believe that on the whole the Conquest was not a development void of benefits. The 1981 article by Bernier does not provide evidence that the behavior of merchants changed in any meaningful way across time and the evidence used is mostly qualitative based on contemporary observations of the society. Such contemporary observations are often tainted by ethnocentrism which makes their relevance dependent on the quality of the empirical data supporting them, empirical data not provided by Bernier either in the 1981 article or in the 1994 book he co-wrote with Daniel Sahlée. See the following sources: Gérald Bernier and Daniel Salée. 1994. Entre l'ordre et la liberté: colonialisme, pouvoir et transition vers le capitalisme dans le Québec du XIXe siècle. Montréal : Boréal; Gérald Bernier. 1981. "Sur quelques effets de la rupture structurelle engendrée par la Conquête au Québec: 1760-1854" Revue d'histoire de l'Amérique française, Vol.35, No.1, pp.69-95; Denis Monière. 1976. "L'utilité du concept de mode de production des petits producteurs pour l'historiographie de la Nouvelle-France", Revue d'histoire de l'Amérique française, Vol.29, no.4, pp.483-502.

${ }^{47}$ Paquet and Wallot have published close to 50 essays and articles on the issue of Quebec's economic history under British rule, the crux of which has been assembled in their 2007 magnum opus: Gilles Paquet and Jean-Pierre Wallot. 2007. Un Québec Moderne, 1760-1840 : Essai d'histoire économique et social. Montréal: Éditions Huburtise HMH. ${ }^{48}$ Donald Fyson. 2012. "The Conquered and the Conqueror: The Mutual Adaptation of the Canadiens and the British in Quebec, 1759-1775" in eds. Phillip Bucker and John G.Reid, Revisting 1759: The Conquest of Canada in Historical Perspective. Toronto: University of Toronto Press, p.191.
} 
And yet, there is a still a great deal we do not know about the post-Conquest period (...) All of these statements are at best misleading and at worst entirely false. And they are not the sort of ordinary empirical errors to which all historians are subject. (...) Still, it is generally not their authors who are at fault, for most are simply synthesizing previous work. Instead, it is the basic empirical research that has largely gone by the wayside, as few scholars have been interested in revisiting the historiography or even the archives [emphasis mine]. ${ }^{49}$

The stalemate described by Fyson is associated with large implications; it concerns a key moment in both Quebec and Canada's economic history. However, this stalemate centres on a poor understanding of the economy both before and after the Conquest. Establishing a portrait of living standards, for either the ante or post Conquest era or both, would go a long way toward solving that issue.

\subsection{The state of the empirical evidence}

The state of the empirical evidence, as described above, can be likened to a statistical dark age. The data that we have regarding Canada prior to the 1850 s emerged progressively from the 1930s onwards with the work of Harold Innis whose study of the fur trade provides rich information about prices and output. ${ }^{50}$ As more and more research emerged over time on the agricultural production of New France ${ }^{51}$, some scholars began to contend that the fur trade hindered the economic development of the colony by directing too many resources to that sector instead of to agriculture. ${ }^{52}$ This has become known as the "dual economy" explanation of economic development in Canada and it is the dominant explanation. On the one hand, there is the fur trade (the main export of the colony) and the agricultural sector on the other hand. ${ }^{53}$ While there were

\footnotetext{
${ }^{49}$ Ibid, p.192.

${ }^{50}$ Harold Innis. 1930 [1999]. The Fur Trade in Canada. Toronto: University of Toronto Press.

51 Alfred Rowland Vanesse. 1958. A Social History of the Seigniorial Regime in Canada, 1712-1739. PhD Thesis, Department of History, University of Montreal; Alice Jean Lunn. 1986 (1942). Développement économique de la Nouvelle-France, 1713-1760. Montréal: Presses de l'Université de Montréal; F.W. Burton. 1936. "The Wheat Supply of New France" Proceeding and Transactions of the Royal Society of Canada, Vol.30, pp.137-150.

52 Kenneth Buckley. 1958. "The role of staple industries in Canada's economic development." The Journal of Economic History, Vol.18, no.4, pp. 439-450; Denys Delâge. 1970. "Les structures économiques de la NouvelleFrance et de la Nouvelle-York", Actualié économique, Vol.46, no.1, pp.67-118; Allan Greer. 1981. "Fur Trade Labour and Lower Canadian Agrarian Structures", Historical Papers / Communications historiques, Vol.16, no.1, pp.197214; Adam Shortt. 1913. "The Colony in its economic relations" in Canada and its provinces: a history of the Canadian people and their institutions by one hundred associates, vol.2, edited by Adam Shortt and Arthur Doughty, Edinburgh University Press, p.478.

${ }^{53}$ Morris Altman. 1988. "Economic Growth, Economic Structure and Real Gross Domestic Product in Early Canada, 1695-1739" William and Mary Quarterly, Vol.45, p.684.
} 
some linkages between those two sectors, they largely evolved separately from each other. ${ }^{54}$ The result was that the economy performed poorly until the Conquest. Most of the evidence underlying this narrative has centered on using data from the fur trade, trade data and results from local studies using either tithe data, probates, engagement contracts or limited census data. Upon closer inspection, this is not a clean-cut argument. For example, using probate records, Yvon Desloges found that the residents of Quebec City saw their living standards decline from the late seventeenth century until the Conquest ${ }^{55}$ while Sylvie Dépatie found increases in probates from the Isle Jésus settlements, north of Montreal. ${ }^{56}$ Using consumption data from patients at the Augustines hospital, François Rousseau found an increase in food consumption. ${ }^{57}$ On the other hand, Serge Lambert found signs of increasing poverty in the colony. ${ }^{58}$ It may be that these findings are the result of regional characteristics unrepresentative of the broader colony, but this is hard to confirm or infer. The issue of assessing living standards has been further complicated by the role that seigneurial tenure may have played in redistributing income from farmers to landlords through the duties imposed by the seigneurs. ${ }^{59}$ Moreover, it may be also highly improper to rely on trade data to compare Quebec with other colonies. According to Morris Altman, furs alone represented 14\% of the output of Canada between 1688 and 1739. However, that share had declined to $9.4 \%$ in 1739 from a high of $18.2 \%$ in $1695 .{ }^{60}$ To this we must add invisible earnings from shipping services, codfish, lumber and some grain exports to the West Indies. According to Paul McCann who assembled the most exhaustive empirical portrait of the trade sector with the James Shepherd and

\footnotetext{
${ }^{54}$ Louise Dechêne.1994. Le Partage des Subsistances au Canada sous le Régime Français. Montréal: Éditions Boréal; Louise Dechêne. 1974. Habitants et Marchands de Montréal au XVIIe siècle. Paris : Plon; Jean Hamelin. 1960. Économie et Société en Nouvelle-France. Québec : Presses de l'Université Laval; Richard Harris. 1966 [1984]. The Seigneurial System in Early Canada. Montréal: McGill-Queen's University.

${ }^{55}$ Yvon Desloges. 1991. A Tenant's Town: Quebec in the $18^{\text {th }}$ century. Ottawa: Parks Canada.

${ }^{56}$ Sylvie Dépatie. 1988. L'évolution d'une société rurale : l'Île Jésus au XVIIIème siècle. Montréal, PhD Thesis, Department of History, McGill University

${ }^{57}$ François Rousseau. 1983. L'œuvre de Chère en Nouvelle-France : Le régime des malades à l'hôtel-Dieu de Québec. Québec Presses de l'Université Laval

${ }^{58}$ Serge Lambert. 2001. Entre la crainte et la compassion: les pauvres à Québec au temps de la Nouvelle-France. Sainte-Foy, Les Éditions GID.

${ }^{59}$ In a 1983 article, Morris Altman ("Seigniorial Tenure in New France, 1688-1739: An Essay on Income Distribution and Retarded Economic Development". Historical Reflections / Réflexions historiques, Vol.10, No.3, pp.335-375) estimated that seigneurial dues absorbed between $37 \%$ and $47 \%$ of net output per household (measured in minots of wheat minus consumption needs and seed requirements) in the 1688-1714 period. By 1726-1739, it had declined to a share ranging between $26 \%$ and $37 \%$. In 1987, he revised his estimates downwards by half as a result of new estimates of seed requirements ("Note on the Economic Burden of the Seigniorial System in New France, 1688-1730". Historical Reflections / Réflexions historiques, Vol.14, No.1, pp.135-142). For his part, Alan Greer estimated that feudal exactions represented $44 \%$ of the wheat surplus produced by farm households in St-Ours (on the south shore of Montreal) in 1765 (1985. Peasant, Lord and Merchant, Rural Society in Three Quebec Parishes, 1740-1840. Toronto: University of Toronto Press, p.136). These estimates are to be taken with a grain of salt. Many seigneuries had context-specific taxes. For example, seigneurs with access to a river way with important halieutic populations could impose a duty on the product of fishing while seigneurs. Thus, there were many auxiliary duties that would have varied according to the specificities of each seigneurie (see the last section of this dissertation).

${ }^{60}$ Morris Altman. 1988. "Economic Growth, Economic Structure and Real Gross Domestic Product in Early Canada, 1695-1739” William and Mary Quarterly, Vol.45, p.703)
} 
Gary Walton ${ }^{61}$ dataset of trade data for 1768 to 1772 , invisible earnings and all non-fur exports were equal to $31.3 \%$ of all exports. ${ }^{62}$ Given that ratio, if fur exports represented $14 \%$ of per capita income, the trade sector must have represented more than $20 \%$ of the economy. In comparison, the entirety of the New England trading sector represented $11.1 \%$ of the region's output — half of which are the "invisible" earnings for services entering the balance payment. That proportion stood at $9.4 \%$ in the Middle American colonies, at $13 \%$ in the Upper South and $9 \%$ in the Lower South. ${ }^{63}$ Given the differences in both the level and the trend of the size of the trade sector, it is hard to use that data to compare living standards and obtain an idea of how they evolved.

The only attempt to measure colony-wide differences in living standards came from Morris Altman ${ }^{64}$ who built his argument on the work of Alice Lunn. ${ }^{65}$ Altman constructed a GDP series for Canada from 1695 to 1739 and showed a modest rate of growth during the period. Moreover, the importance of the fur trade declined progressively during the period according to his figures (from $18.2 \%$ in 1695 to $9.4 \%$ in 1739) as the economy diversified. Basically, Altman created a volume index of GDP with price weights from 1749 - a common method for economists. Most economists would be convinced by the evidence marshalled by Altman that, at the very least there was no negative growth. ${ }^{66}$ However, the absence of continuous time series for prices that are usable $^{67}$ has created a reluctance with regard to accepting Altman's conclusion. For example,

\footnotetext{
${ }^{61}$ James Shepherd and Gary Walton. 1972. Shipping, maritime trade, and the economic development of colonial North America. Cambridge: Cambridge University Press

${ }^{62}$ Paul McCann. 1983. Quebec's Balance of Payments, 1768-1772: A Quantitative Model. M.A. Thesis, Department of History, University of Ottawa.

${ }_{63}$ Peter Lindert and Jeffrey Williamson. 2016. Unequal Gains: American Growth and Inequality since 1700. Princeton, NJ: Princeton University Press, p.47-49.

${ }^{64}$ Morris Altman. 1988. "Economic Growth, Economic Structure and Real Gross Domestic Product in Early Canada, 1695-1739" William and Mary Quarterly, Vol.45, p.684-711.

${ }^{65}$ Alice Jean Lunn. 1986 (1942). Développement économique de la Nouvelle-France, 1713-1760. Montréal: Presses de l'Université de Montréal

${ }^{66}$ There are some problems with some assumptions regarding output and regarding the representativeness of the weights. These issues are discussed later in this dissertation. However, that rate of growth is not far from those observed by some for the United States (see: Marc Egnal. 1975. "The Economic Development of the Thirteen Continental Colonies, 1720 to 1775" William and Mary Quarterly, Vol.32, no.2 p,191-222; Gloria Main and Jackson Main. 1988. "Economic Growth and the Standard of Living in Southern New England, 1640-1774" Journal of Economic History, Vol.48, no.1, p.36; Alice Hanson Jones. 1980. Wealth of a Nation to Be. New York: New York University Press; John J.McCusker and Russell Menard.1991.The Economy of British America, 1607-1789. Chapel Hill, NC: University of North Carolina Press). However, it is above the rate of growth found by Mancall and Weiss (Peter Mancall and Thomas Weiss. 1999. "Was Economic Growth Likely in Colonial British North America" Journal of Economic History, Vol.59, no.1 p.17-40) and by Lindert and Williamson (Peter Lindert and Jeffrey Williamson. 2016. Unequal Gains: American Growth and Inequality since 1700. Princeton, NJ: Princeton University Press).

${ }^{67}$ To be sure, there are prices provided by François Rousseau (1983. L'euvre de Chère en Nouvelle-France: Le régime des malades à l'hôtel-Dieu de Québec. Québec Presses de l'Université Laval) and by Yvon Desloges (1991. A Tenant's Town: Quebec in the $18^{\text {th }}$ century. Ottawa: Parks Canada). The problem is that both are for urban areas. In addition, the data provided by Rousseau is provided in a format that is not readily usable. The data provided by Desloges has numerous gaps and is drawn from probate records. This is an issue since the prices in Desloges are not market prices but rather prices estimated by notaries. I do not believe that Desloges' data would be unsuited for trend
} 
Catherine Desbarats, asserts that "weighting all quantities by the price of a single year is a costly short cut" since the assumption of prices being stable over time was too strong. ${ }^{68}$

The uncertainty about the state of the economy before 1760 is compounded by the uncertainty about the state of the economy after 1760. In a 1986 essay, Louise Dechêne described the state of the statistical sources as "poor" in the post-Conquest era. ${ }^{69}$ It is partly on the poverty of the data available that she blames the stalemate in the literature. She extends this criticism to the era of New France although the problem is less pronounced for that period of time since censuses were taken more regularly while close to five decades years separate the 1784 census to the 1827 and 1831 censuses. ${ }^{70}$ In 1974, French historian Jacques Le Goff reviewed the debate on the agricultural crisis of 1802 that pit Fernand Ouellet on the one side against Jean-Pierre Wallot and Gilles Paquet on the other. ${ }^{71}$ Ouellet argued that performance was dismal and he has received considerable support from many economists and historians. ${ }^{72}$ In the minority, Paquet and Wallot argued that the economy was more buoyant and growth was robust — a view that has received some econometric support and empirical support. Scathingly, Le Goff argued that neither side could muster sufficiently convincing evidence to make their case. In the end, Le Goff faulted both sides and claimed that (although he believed it to be impossible) the only way to break the deadlock would be to create a "national accounting model" of the colonial economy. In his eyes, as long as there was no large and continuous statistical portrait of the economy, the issue could not be resolved. It also means, in our case, that we cannot accurately document the trend of living

analysis, but it might fail to properly capture the level of prices which is a considerable issue for the estimate of the welfare ratios which is the topic of part three of the current dissertation.

${ }^{68}$ Catherine Desbarats. 1992. "Agriculture within the Seigneurial Régime of Eighteenth Century Canada: Some Thoughts on the Recent Literature", Canadian Historical Review, Vol.73, no.1, p.10. Note: I should point out that the criticisms towards Altman's paper are overdoing it. Angus Maddison felt the data sufficiently well-constructed to warrant inclusion in his historical statistics of GDP (Angus Maddison. 2003. The World Economy: Historical Statistics. Paris: Organisation for Economic Cooperation and Development, p.75). This is not to say that there is no way to improve upon Altman's work, but most reasonable corrections won't affect the level and trend of Altman's result. In part 4 of this dissertation, I make a series of methodological improvements to the Altman paper and find no difference in the trend from 1695 to 1739 . I arrive at a different interpretation because I extend the series to include 1688 and 1762. Moreover, the contention made by Desbarats was similar to one made in the early debates over measuring British GDP during the Industrial Revolution and the issue was later shown to be moot (see: Nicholas Crafts, and Knick Harley. 1992. "Output growth and the British industrial revolution: a restatement of the CraftsHarley view." The Economic History Review 45, no. 4, pp. 703-730).

${ }^{69}$ Dechêne, Louise. 1986. "Observations sur l'agriculture du Bas-Canada au début du XIXe siècle” in Évolution et Éclatement du Monde Rural, France-Québec XVII-XXè siècles eds. Joseph Goy and Jean-Pierre Wallot, Paris and Montréal : Presses de l'Université de Montréal and Éditions de l'École des Hautes Études en Sciences Sociales, p.190. ${ }^{70}$ For reasons that could be subject to a dissertation by themselves, historians overestimate the troubles posed by the 1784, 1827, 1831, 1842 and 1844 censuses of Canada. While they must be used with care, they can provide rich information about production, especially if they are complemented with other sources to confirm conjunctures and linked appropriately with the less-scorned censuses of the French era.

71 T.J.A Le Goff. 1974. "The Agricultural Crisis in Lower Canada, 1802-12: A Review of a Controversy" Canadian Historical Review, Vol.55, no.1, pp.1-31.

72 Most notable among the supporters is John McCallum. 1980. Unequal Beginnings: Agriculture and Economic Development in Quebec and Ontario until 1870. Toronto : University of Toronto Press. 
standards past 1760. Hence, data on the "ante" and "post" conquest era are lacking and it is hard to solve the issue. Any assessment of the impact of a regime change requires a good empirical portrait of the situation before the change. This is missing, and the creation of such a dataset would constitute a tremendously valuable first step. In short, a quantitative essay is needed to allow historians to break the deadlock, both before and after the Conquest.

However, the undertaking of such a task is immense in scope as it would require collecting prices and wages from the era of New France up to the beginning of Confederation in 1867. Although a worthy endeavour, it is better to limit our scope initially to the ante-conquest era. Eventually, I intend to extend this effort to the era of British rule, but at present that task is too daunting for a doctoral thesis. This is not because the work is of poor quality, but because much of it has been lost. For example, Gilles Paquet and Jean-Pierre Wallot constructed a price index for the period from 1760 to 1867 . Gilles Paquet kindly offered to share his raw dataset of prices which they used and which he and the late Wallot (who died in 2007) deposited at Library and Archives Canada. ${ }^{73}$ Sadly, the file for prices was not contained within the boxes of the fund they created at the institution (even while the inventory reported it as present). Either the original was misfiled, was lost or was stolen. This means that their diligent data collection work must be repeated. Louise Dechêne noted as much in her work when she pointed out that much of Fernand Ouellet's own dataset of prices was not publicly available which forced other researchers to "restart from zero". ${ }^{74}$ Moreover, as will be seen below, the construction of consistent datasets for New France requires a long methodological effort and discussion which is different in nature and in detail than the construction of datasets for the English era. Consequently, it is better to divide to tackle each period separately, beginning with the era of New France.

No solutions to the debates about Quebec's and Canada's history where living standards are an issue can emerge without a proper portrait of living standards of the ante-conquest era. Hence the necessity to begin painting this portrait from the start-i.e. from the time of French rule. I hope that my future research will allow me to paint the second portrait covering the English era.

\footnotetext{
${ }^{73}$ Library and Archives Canada. 1991. Fonds Paquet-Wallot : Projet de Recherche sur la Culture Matérielle et Société au Québec, 1792-1835. MG 31 D227.

${ }^{74}$ Dechêne, Louise. 1986. "Observations sur l'agriculture du Bas-Canada au début du XIXe siècle" in Évolution et Éclatement du Monde Rural, France-Québec XVII-XXè siècles eds. Joseph Goy and Jean-Pierre Wallot, Paris and Montréal: Presses de l'Université de Montréal and Éditions de l'École des Hautes Études en Sciences Sociales, p.191. Note: It is important to note that Ouellet did publish some of his data in Fernand Ouellet, Jean Hamelin and Richard Chabot. 1982. "Les prix agricoles dans les villes et les campagnes du Québec d'avant 1850: aperçus quantitatifs" Histoire Sociale / Social History, vol. 15, no. 29, pp. 83-128. However, other price series like those for pine planks are absent from that source. Also absent are important datasets related to imports (butter, pork, tobacco, beef, cheese) and public spending. Although not a terribly demanding task, consulting each individual journal of the House of Assembly of Lower Canada to transcribe each value is time consuming.
} 


\subsection{The goal of this dissertation}

The goal of this thesis is modest in scope (but ambitious with regard to the effort required): to create an empirical portrait of living standards in Quebec during the French era. This portrait should allow us to gain a robust estimate of the level of living standards relative to other societies and to evaluate the evolution of living standards over time. In essence, this is an empirical essay. To do so, this dissertation aims to generate three important empirical advancements:

a) Generate a price index - something which does not exist at present - based on price data contained in account books of religious congregations. This will allow us to link with the Paquet-Wallot price index that covers the 1760-1860 era and later produce an entirely new index based on prices drawn from homogenous sources;

b) Generate measures of real wages, incomes and welfare ratios that can be compared with measures from other societies like England, the home country of France and the British colonies in America. Additionally, these measures will rely on welfare ratios that account for the fact that frontier economies tended to have higher prices for manufactured goods and services relative to food items while the opposite was true in the Old World economies (something that past price deflators did not address);

c) Generate new measures of GDP that complement the wage estimates (as welfare ratios based on wages face a strong limitation in the form of the number of work days one must assume). As a result, we will obtain measures of income per capitaalbeit for a more limited number of years - that will allow us to better compare trends and levels (using welfare baskets designed in B); and

d) Provide exploratory (and speculative) explanations of the differences in living standards during that period in order to guide future research.

The interests for other researchers are manifold. First of all, it produces the first step to estimating the economic effects of the British conquest of Canada. Secondly, it provides the first estimation of differences in living standards between France and New France. This will be of great interest for Canadian historians who have dedicated important research papers and books on the issue of the influences and differences between France and Quebec. It also provides the counterstory to economic historians who compared living standards in Britain to those of its colonies in America by doing the same between Quebec and France. Thirdly, it documents that Quebec's poor performance within Canada since confederation had roots in the early colonial era. This could contribute to the debate between nationalist and federalist historians, and political scientists and economists in Canada who debate the impact of Confederation on Quebec. Fourthly, and most importantly in the opinion of the author, it provides evidence of divergence within North America 
during the colonial era. This suggests a potential contribution to the debate between economic historians on the initiation of divergence. This possible contribution yields the greatest importance to me.

\subsection{The plan of this dissertation}

The structure of this dissertation is as follows.

Chapter 2 will provide the first foundation of any empirical estimates of living standards by creating a price index with data drawn from the archives of two religious congregations from the Quebec City area (the Séminaire de Québec and the Ordre des Ursulines de Québec) whose account books provide rich information with regard to prices.

Chapter 3 is in logical continuity with the previous as it uses wage data contained in the same sources in order to measure living standards. This section will then attempt to draw up comparisons of living standards by creating welfare ratios out of the price and wage data.

Chapter 4 argues that the results obtained in part 4 are necessary but not sufficient to assert that the inhabitants of Quebec were poorer than the inhabitants of other colonies or of the mother country. Further evidence is brought forward through the (re)computation of national income estimates and vital statistics.

Chapter 5 will act as a long discussion to highlight the importance of my contribution. But more importantly, this chapter will act as a roadmap for future research (which I intend to undertake). It argues that Quebec's small population was the overarching problem of the colony as its small size and low population density meant thin labor markets, limited trade networks, limited opportunities for specialization and few economies of scale. However, this overarching problem was amplified by institutional structures, mostly the seigneurial system of land tenure.

In the concluding section of this thesis, the author will also underline how this quantitative essay lays the foundations for answering numerous other questions related to Canadian economic history. 


\subsection{The results}

The main takeaways from this dissertation are the following:

1) The price level exhibited no trend in the long run. However, prices were very volatile and there were numerous large shocks related to wars and questionable monetary policy.

2) The evolution of prices in Canada was similar to the evolution of prices in the American colonies.

3) The ratio of prices of imported goods to exported goods increased significantly throughout the period.

4) The ratio of prices of non-agricultural domestic goods to domestic agricultural goods increased significantly throughout the period.

5) Real wages, standardized as welfare ratios, show that there was no economic growth between 1688 and 1760. This observation holds under different specifications of the consumption basket.

6) Real wages, standardized as "bare bones" welfare ratios (with a consumption basket based primarily on land-intensive goods and aimed at assuring the bare minimum for subsistence), show that Quebec was not substantially richer than France. It was poorer than Britain and the American colonies.

7) Using welfare ratios based on a more respectable basket of goods (with more capital intensive goods, manufactured goods and imported goods), the advantage New France enjoyed relative to France disappears entirely. The gap it suffered relative to the American colonies widens.

8) The results underlined in points 4 and 5 show that there was divergence within North America during the colonial era. A gap whose width was similar to the one observed between the American colonies and Spanish America.

9) The creation of a GDP index shows that there was no growth in per capita income between 1688 and circa 1760.

10) The absence of economic growth was accompanied by signs of harder and longer work on the part of the inhabitants. This observation is hard to corroborate satisfactorily. However, it accompanies another (clearly observed) observation that the biological standard of living deteriorated significantly throughout the era of French rule (increases in infant mortality and crude death rates), something which did not occur in the American colonies.

11) The results underlined in points 7 and 8 show that Quebec experienced a path of growth similar to that of the American colonies (near zero) and that the gap did not widen (except episodically in wartime). However, the strength of that conclusion hinges greatly on the state of the empirical evidence for the American colonies (which does 
not fully rule out positive growth) which means that this conclusion is a best case scenario (at worst, the gap widens).

12) The size of Quebec's population was probably an important contributor to its economic performance. Sparsely populated over a large territory, trading networks were hard to form and economies of scale were limited.

13) The overarching problem of population size was likely amplified by institutional factors - most importantly the system of seigneurial tenure. However, it is beyond the scope of this dissertation to assert this importance with reasonable precision. Nonetheless, it suggests that future research should tackle the importance of seigneurial tenure. 


\section{PART 2: CREATION OF A PRICE INDEX, 1688 TO 1760}




\subsection{We don't know how prices moved!}

In an interview in 1980 on the French network of the Canadian Broadcasting Corporation $(\mathrm{CBC})$, the eminent historian Jean Hamelin explained his work on New France to the general public. He had collected data on wheat prices in Quebec City, in the tradition of French historian Ernest Labrousse, in order to predict living standards. Hamelin reasoned that in the instance of crop failure, prices would be high, indicating that the farmers were not able to buy products from other industries in France. The economy would collapse. This assertion of his has failed to convince. ${ }^{75}$ The main reason for this failure was that he only collected wheat prices which were presented in money terms and not in real terms. In the interview, Hamelin conceded that he wished he "had gone further" in terms of substantiating his section on living standards. ${ }^{76}$

Today, if one were to ask the question of "how did prices move in Canada," the answer would be a deafening silence. There are no broad price series that allow researchers to determine price movement. There is a price index available for the years following the conquest (from 1760 to 1860), which was produced by Jean-Pierre Wallot and Gilles Paquet, but these authors never extended their work to the earlier period. ${ }^{77}$ Moreover, in spite of the tremendously-generous collaboration of Mr. Paquet, it was impossible to retrace the raw data they used for this period. ${ }^{78}$ Hence, all we are left with is their price index in its current form (an equal weight basket of prices for 20 goods).

For the French era, the works of François Rousseau and Yvon Desloges are the closest anyone has come to creating a reliable empirical estimation of price movements in New France. Rousseau aggregated all expenditures in total for certain categories, like food, in order to derive the cost per patient and per ration, which allows researchers to obtain a clear picture of the evolution of the costs of food. ${ }^{79}$ Unfortunately, Rousseau never broke down the baskets for numerous items on a year-to-year basis. He presented the price of 100 calories of each item for every five-year period. This prevents researchers from obtaining annual variations in price. Rousseau also failed to provide information on how many calories he attributed to the different

\footnotetext{
${ }^{75}$ Robert Armstrong. 1984. Structure and Change: An Economic History of Quebec. Toronto : Gage Publishing, pp.2425 .

76 Services des Transcriptions et Dérivés de la Radio. 1980. Émergence d'une colonie à deux versants. Montreal, Société Radio-Canada, p.6.

77 Gilles Paquet and Jean-Pierre Wallot. 1998. "Some Price Indexes for Quebec and Montréal (1760-1913)", Histoire Sociale / Social History, vol.31, no.62, pp.281-320.

${ }^{78}$ It seems that some documents might have been lost at Library and Archives Canada. Mr. Paquet, who kindly helped out, assured us that the data was available in the spreadsheets at the archives. Yet, they are not in any of the boxes. Moreover, the information contained within those boxes pertains only to the years from 1792 to 1835 with some gaps in between. It must be assumed that the error lies in the archiving process.

${ }^{79}$ François Rousseau. 1983. L'œuvre de Chère en Nouvelle-France : Le régime des malades à l'hôtel-Dieu de Québec. Québec Presses de l'Université Laval, p.94.
} 
items. Hence, it is impossible to truly replicate Rousseau's work for the purposes of comparing specific goods. Moreover, there are non-continuous estimates of certain food items over periods of 10 years, but nothing of the sort for non-food items, like nails or clothing. All other price information is centered on the price of wheat in Quebec and Montreal. ${ }^{80}$ As for Desloges, he considered only urban prices derived from unreliable probate records (and, more importantly, with numerous very large gaps and unrepresentative goods). ${ }^{81}$ Table 2.1, below, presents details of these other sources of information. As one can see, we are left with very poor price information.

The last problem is the absence of a long-term price index that covers both the French and British eras of rule over the colony. Any long-run research agenda would aim at creating such an index. As mentioned earlier, Paquet and Wallot produced a price index that spanned from 1760 to 1913. That index was non-weighted and merely the average of the price index for all the goods they included. It ought to be mentioned that the original data for their index has been lost and a new collection effort must be mounted to resolve that issue. Prices indexes for Canada past 1840 are more frequent, but prior to 1840 , there is a dearth of information. ${ }^{82}$ Any effort to fill that important gap in quantitative information about Canada would inevitably start with the era of New France. Eventually, the sources described below will allow researchers to take the second step of re-collecting price quotations to recreate Paquet and Wallot's index, while also creating a cost of living index.

\footnotetext{
${ }^{80}$ Jean Hamelin. 1960. Économie et Société en Nouvelle-France. Québec: Presses de l'Université Laval; Louise Dechêne.1994. Le Partage des Subsistances au Canada sous le Régime Français. Montréal: Éditions Boréal.

${ }^{81}$ Yvon Desloges. 1991. A Tenant's Town: Quebec in the $18^{\text {th }}$ century. Ottawa: Parks Canada. Note: The only upside from Desloges' work is the presence of a non-continuous price series for silver. The problem is that there are some gaps (in some of the early years and after 1749) and that we cannot rely on the French silver conversion ratio (since it does not behave in the same manner).

${ }^{82}$ Here is a partial list: Clint Levitt and Herbert Emery. 2002. "Cost of Living, real wages and real incomes in thirteen Canadian cities, 1900 -1950" Canadian Journal of Economics, Vol.35, no.1, pp.115-137; Chris Minns and Mary McKinnon. 2007. "The costs of doing hard time: a penitentiary-based regional price index for Canada, 1883-1923", Canadian Journal of Economics, Vol.40, no.2, pp.528-560; Donald G. Paterson and Ronald Shearer. 2003. "A history of prices in Canada, 1840-1871: a new wholesale price index", Canadian Journal of Economics, Vol.36, No.1, pp.224253; M.C. Urquhart. 1993. Gross National Product, Canada, 1870-1926: The Derivation of Estimates. Kingston: McGill-Queen's University Press; Michael Hinton and Vincent Geloso. 2015. "The Emperor has no clothes: a new price index for Canada, 1870-1900", Conference paper presented at the Canadian Economics Association on May $28^{\text {th }}$ 2015.
} 
Table 2.1. Summary of the existing data sources on prices in New France

\begin{tabular}{|c|c|c|c|}
\hline Source & Coverage & $\begin{array}{l}\text { Goods and } \\
\text { geography }\end{array}$ & Problem \\
\hline Paquet and Wallot (1998) & 1761 to 1860 & $\begin{array}{l}20 \text { goods in Quebec, } 10 \\
\text { in Montreal }\end{array}$ & $\begin{array}{l}\text { Non-weighted and } \\
\text { original data not } \\
\text { available }\end{array}$ \\
\hline Rousseau (1983) & $\begin{array}{c}1683 \text { to } 1760 \text { (with some } \\
\text { gap years) }\end{array}$ & $\begin{array}{l}\text { Food items and cost of } \\
\text { the daily food ration }\end{array}$ & $\begin{array}{c}\text { Grouped in five-year } \\
\text { intervals, impossible to } \\
\text { compute data, numerous } \\
\text { gaps, non-continuous for } \\
\text { many goods }\end{array}$ \\
\hline Hamelin (1961) & 1674 to 1759 & Wheat in Quebec & $\begin{array}{c}\text { Sole commodity present } \\
\text { is wheat }\end{array}$ \\
\hline Dechêne (1994) & 1675 to 1760 & $\begin{array}{c}\text { Wheat in Montreal (1675 } \\
\text { to } 1718) \text { and Île Jésus } \\
(1718 \text { to } 1760)\end{array}$ & $\begin{array}{l}\text { Sole commodity present } \\
\text { is wheat }\end{array}$ \\
\hline Desloges (1991) & 1690 to 1749 & $\begin{array}{c}\text { Numerous goods in } \\
\text { Québec City }\end{array}$ & $\begin{array}{l}\text { Urban prices with large } \\
\text { gaps based on probates } \\
\text { taken at ill-specified } \\
\text { seasons. Few continuous } \\
\text { data series, especially for } \\
\text { most commonly } \\
\text { consumed goods }\end{array}$ \\
\hline
\end{tabular}

Sources: see text for Paquet and Wallot and Rousseau; Jean Hamelin. 1960. Économie et Société en Nouvelle-France. Québec : Presses de l'Université Laval; Louise Dechêne.1994. Le Partage des Subsistances au Canada sous le Régime Français. Montréal: Éditions Boréal; Yvon Desloges. 1991. A Tenant's Town: Québec in the 18 ${ }^{\text {th }}$ century. Ottawa: Environment Canada Parks Service.

The creation of a price index for New France would be very helpful for the study of the economic history of Canada and North America. It is the necessary first step in order to create reliable price deflators and price information in order to measure real output, terms of trade and relative prices. Down the line, it might permit the estimation of agricultural productivity measurements following the methodology advanced by Robert Allen. ${ }^{83}$ It would also permit the creation of series for Gross Domestic Product (GDP). In turn, this would allow for a reliable comparison of growth across North America. Ultimately, it would provide a benchmark of Canadian growth compared to that of the American colonies at a time when the two economies looked increasingly similar. Indirectly, the collection of such price data will also allow studies about market integration within the Atlantic commercial sphere.

In this section of the present dissertation, I will create a price index that differs from the cost of living measure we will derive in section 3 . The price index derived in section 3 , inspired by the work of Robert Allen, contains few goods and is designed to compare real wages across space by adjusting for purchasing power parities. The index in this section contains a large number

\footnotetext{
${ }^{83}$ Robert Allen. 2000. "Economic structure and agricultural productivity in Europe, 1300-1800", European Review of Economic History, Vol.4, no.1, pp.1-25.
} 
of goods, compares relative prices and is meant to be linked with later indexes (see notably Appendix 3).

The data are discussed in section 2.2, whereas the reliability of the data testing is discussed in in section 2.3. In section 2.4, I produce a basket of the cost of living based on secondary sources concerning consumption. The goal of section 2.5 is to pre-empt one criticism linked with the impact of inequality in a frontier economy like New France that some could likely put forward regarding the construction of the cost of living. I show that the basket discussed in section 2.4 is reliable, and that specification and method changes do not significantly alter the results. Section 2.6 provides comparison of relative prices. Although I will present the gist of the new sources I used to construct a price index, the details are contained in Appendix 1 for interested readers.

\subsection{Data sources and measurements}

To solve the problem of the lack of a price index, prices were collected from different religious congregations in Quebec. These congregations were excellent sources of information. The main source was the Séminaire de Québec, a religious community located in what is currently the oldest part of Quebec City. It was founded in 1663 and held significant land assets. Because of the needs of the religious community and of the land assets it held, the Séminaire's account books provided important data on a wide range of transactions for a wide range of goods and services. ${ }^{84}$

This source turned out to be of great value because the monetary terms listed were all expressed in a similar unit, allowing for reliable computing of the prices of goods. It should be noted that this source had been tapped in 1961 by Jean Hamelin. ${ }^{85}$ However, Hamelin only collected data for the price of wheat in order to sustain the argument that wheat prices stood as the foundation of real income in the colony. By combining the Grand Livre (series C4, C5, C7, C8 to C11), the Grand Livre Auxiliaire (series C6), the Brouillard des Revenus et Dépenses and other official information sources from the Séminaire, prices could be derived on an annual basis from 1688 to 1760 in great detail. The only difference between the Grand Livre and the Brouillard lies in the tabulations of transactions. The latter has a hard-to-read tabulation of day-to-day transactions, while the former has the transcription of these transactions in a more readable format, and is organized on the basis of accounts with clear citations of the year of transaction. Other than that, the two sources are identical: all prices recorded in a Brouillard were eventually transcribed in a Grand Livre. With regard to frequency, the different prices reported were collected for each year in the account books and averaged. For some goods, like wheat, there were variations of price during the year. However, for goods like burning oil, oats, peas, olive oil, nails, spirits, wine, beef, butter, and lard, prices rarely changed over the course of a year.

\footnotetext{
${ }^{84}$ Noël Baillargeon. 1977. Le Séminaire de Québec de 1685 à 1760. Québec : Presses de l’Université Laval.

${ }^{85}$ Jean Hamelin. 1960. Économie et Société en Nouvelle-France. Québec : Presses de l'Université Laval.
} 
Some goods had gaps between years, so I resorted to using the Livre de Compte of the Ursulines de Québec. The Ursulines was a religious congregation headed by nuns who were devoted to the education of young girls and native girls. That said, the information derived from both institutions can be combined without much loss of reliability, given that the geographic distance between the two religious congregations is less than two kilometres. However, their estates outside Quebec City were far apart. For both institutions, prices move similarly at the same levels which speaks to the reliability of each taken alone. Figure 2.1, below, compares the data series for wheat prices collected at the Ursulines with the data collected at the Séminaire. Movement of prices collected from both places followed a very similar path.

Figure 2.1. Price of a minot of wheat depending on the source, in sols, 1718 to 1760

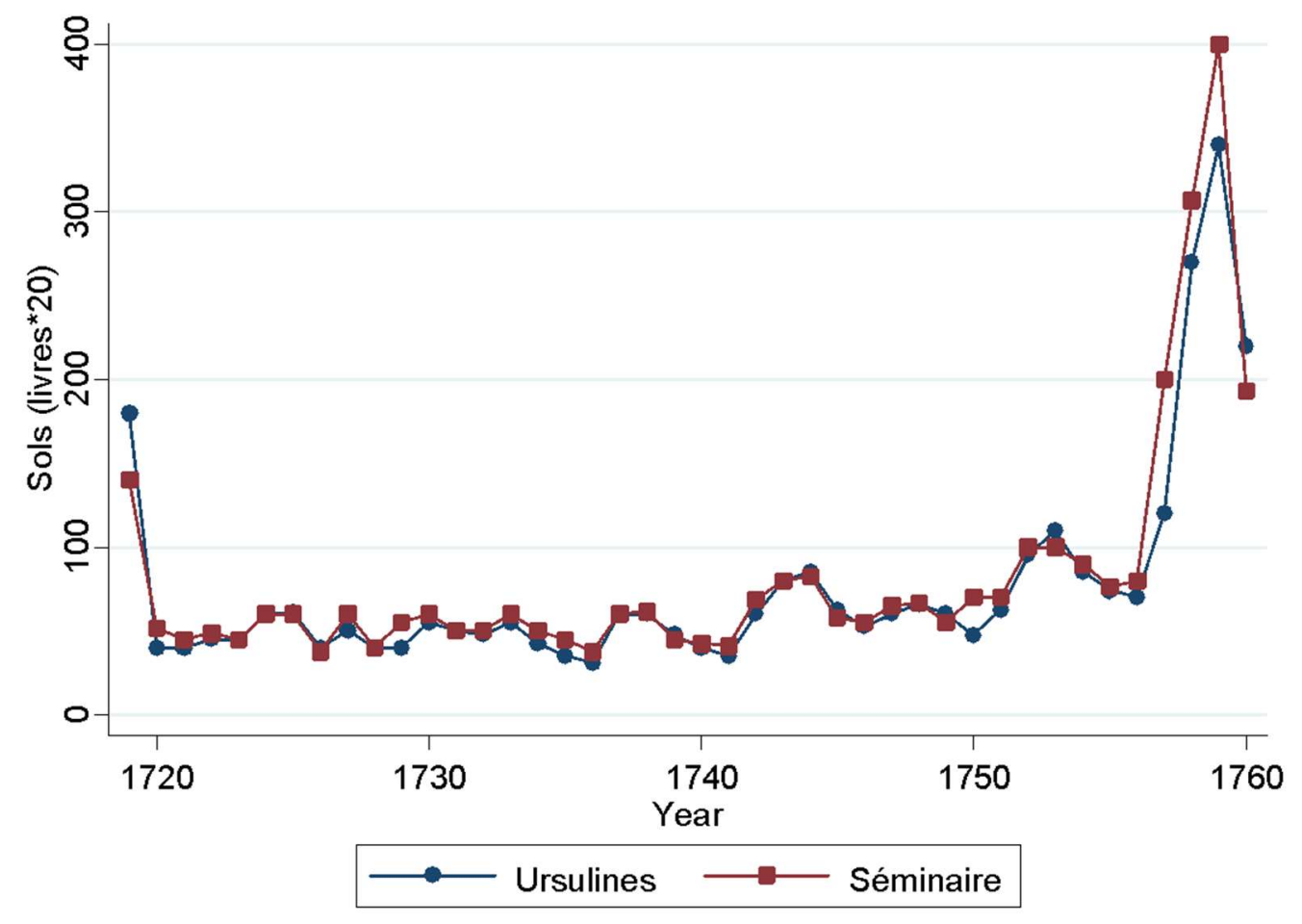

Before proceeding, it is necessary to mention that the prices reported in the account books are not currency per se; they are units of account. In short, these prices are like "ideal prices" or what researchers might call "ideal money." The dissociation between units of account and units of exchange is not something to which readers may be accustomed, given that in the modern day, they are one and the same. But, for economic historians, this is very common. When the Séminaire reported that it had paid for 30 livres worth of wheat, it meant that they had paid with currency 
whose value they estimated would provide them with the accounting value of 30 livres. ${ }^{86}$ As Bruce McCullough pointed out, units of account were generally used in account books like those used today. ${ }^{87}$ This disassociation had the advantage of creating a steady yardstick. Depending on the effective supply (i.e., quality adjusted) of each type of medium of exchange, prices would be quoted in relation to that yardstick measure. If the supply of money changed, it would have been the price of that money in terms of the account book money that would have changed, not the price quoted of an item quoted in "ideal prices." What this means is that buyers and sellers quoted prices for different currencies in ideal prices. Both the staff at the Séminaire and the examinations of the account books confirmed this. When currency was mentioned, it was to indicate that something had been bought or sold in a given currency for 30 livres worth. It is very rare, and it happened mostly for the last years of the French regime, that price quotes were found in a given unit of currency, but these always related to the official rates of exchange and researchers know very little about the exchange rates between different currencies. Researchers only know the "account book" value of goods.

Throughout the period, the account books report their credits and debits in monnoye du pays, which means that adjustments are unnecessary. In his work, Hamelin transformed the monnoye du pays into monnoye de France. After 1719, this was not a problem because legal tender laws set the two accounting systems at par. However, prior to 1719 , the monnoye du pays was worth one fourth less than the monnoye de France. Hamelin, for unspecified reasons, transformed the units reported in monnoye du pays into monnoye de France. ${ }^{88}$ Louise Dechêne also deflated prices for Montreal wheat, which were expressed in monnoye du pays, into French accounting units. Again, no reason for this deflation of prices was offered ${ }^{89}$ In addition, they disagree on how to deal with the debasements and the figures to attribute return to a common accounting unit. In 1661 , the edict which fixed the monnoye du pays at 25\% above the level of the monnoye de France caused an influx of poor-quality coins and price levels rose to reflect the intrinsic value of the money supply. ${ }^{90}$ When the legal tender laws changed to bring these two accounting units back to parity, better coins progressively began to resurface. Although the official rate of exchange between the two systems of accounting became equal, the effective rate must have taken a longer time to adjust itself. So in the few years after 1719, using the official exchange rate must have underestimated the true levels of prices quoted in the monnoye $d u$ pays, as the money supply adjusted progressively. Another problem of a similar nature also occurred in the years between

\footnotetext{
${ }^{86}$ The reader should be aware that the monetary unit of the livre was quite similar to that of the British pound where livres should be replaced by pounds, sols replaced by shillings and deniers by pence. One livre equalled twenty sols and one sol equalled twelve deniers.

${ }^{87}$ A.Bruce McCullough. 1990. Money and Exchange in Canada to 1900. Toronto: Dundurn Limited Press, p.17.

${ }^{88}$ Jean Hamelin. 1960. Économie et Société en Nouvelle-France. Québec : Presses de l'Université Laval, p. 16.

${ }^{89}$ Louise Dechêne. 1994. Le Partage des Subsistances au Canada sous le Régime français. Montréal: Boréal, p.198

${ }^{90}$ Roeliff Morton Breckenridge. 1893. "The Paper Currencies of New France" Journal of Political Economy, Vol.1, No.3, p.407-410.
} 
1714 and 1719, when the government issued important quantities of paper money printed on playing cards which were denominated in monnoye du pays. Doubts about the value of these units led to significant discounting on these notes, and their flooding of the market caused individuals to either hoard coins or rapidly spend the paper money. This meant that there must have been a high premium on specie, which was denominated in monnoye de France. Hence, using the official conversion rate would probably underestimate the price changes when the colony was under a paper money system. This is why the researcher for this project prefers to use the monnoye du pays account system directly because it captures changes in the money supply more efficiently.

Some will wonder why I have not converted into silver prices. There is a data series provided by Yvon Desloges that looks at silver prices between 1691 and 1749 with a gap in 1695 . That data series is interesting but it is slightly lower than the level observed in France (even after adjusting for the differences between monnoye du pays and monnoye de France). In addition, each time the colonial government experimented with paper money, the values became not only divorced in levels, but also in movement. The silver price series discussed by Desloges ends in the middle of another experiment with paper money. As a result, I cannot reliably interpolate the missing points using the exchange rate in France. Arguably, these problems seem minor, but so is the importance of resolving them, especially when the efforts needed are colossal. The welfare ratios (a defined basket divided by wages multiplied by length of work year) which will be constructed later (see next chapter) do not change when I use prices converted into silver. The conversion of prices and wages using the same silver conversion rate will not affect the ratio of the two. ${ }^{91}$ The efforts needed to resolve this require the collection of probate records which notarized silver values - an effort equivalent to the thirteen months needed to collect the price data contained in this dissertation.

The advantage of these sources of price data is that these are prices paid (or asked) by the Séminaire and the Ursulines for goods and services. Probate records, on the other hand, often report prices estimated by a notary who evaluated — sometimes arbitrarily - the value of goods left in inventory. In short, probate records do not record market prices. For their part, the data from the Séminaire and the Ursulines could be more easily qualified as wholesale data since the quantities exchanged were very large. The data do have downsides. Researchers tend to prefer the price of bread over the price of wheat or flour. Unfortunately, bread prices were heavily regulated in Quebec City which makes them hard to consider. ${ }^{92}$ It is probably as a result of the regulations that the two religious congregations reported the price of a "unit" of bread but not the weight of that

\footnotetext{
${ }^{91}$ Nick Mayhew also makes this point arguing that converting wages into grams of silver may have some pitfalls on top of yielding no advantages when we calculate welfare ratios. See: Nick Mayhew. Forthcoming. "Money in England from the middle ages to the nineteenth century" in Coins, Currency and Crisis, London: Routledge Press, pages undetermined.

${ }_{92}$ Yvon Desloges. 1991. A Tenant's Town : Québec in the $18^{\text {th }}$ century. Ottawa: Environment Canada Parks Service, pp.142-143.
} 
"unit". For example, if a labourer at the farms of the Séminaire had bought a "pain de quinze sols" (a piece of bread worth 15 sols), researchers are almost never given the true weight of this piece of bread. Often, the bakers found ways around the price controls, notably by cheating on weights. In addition, they tended to buy wheat which they milled themselves without properly cleaning it. As a result, the bread produced tended to contain appreciable quantities of dirt which gave it a distinctly dark color and poor taste which peasants often complained about. ${ }^{93}$ Thus, the weight of the bread often included the weight of dirt from uncleaned wheat. Yvon Desloges argues that, in Quebec City, one third of landlords made an oven available for their tenants so that they could bake their bread themselves. ${ }^{94}$ This probably allowed a substantial share of the urban population to evade the price controls partially. In the hinterland, milling could be done by hand with the use of small mill stones. The combination of these factors explains the limited information I collected for bread and explain the use of wheat and flour instead.

The prices of the other goods were abundant and were clearly reported with minor issues. Fernand Ouellet and his co-authors, who used religious congregations for a small number of goods, argued that the prices collected in the account books ought to be considered as retail prices. ${ }^{95}$ For numerous goods, the Séminaire and the Ursulines rarely altered the prices. For example, all mentions of lighting oil prices are similar year round. The same applies for eels, salt, beef, butter, lard, nails, olive oil, planks, and candles. Imported goods contained very few elements of seasonality. The reason for this is easily explainable: Quebec's ports were blocked off by ice in the winter, which prohibited international trade from late October to mid-April. Imported goods were generally bought straight off the boat when they arrived. Often, they were bought on credit at the beginning of the sowing season. However, the prices of agricultural goods were not always reported in the same month. I opted to collect all the differently-reported prices in each year (the single largest number of different observations recorded in a given year was five). I averaged all these different price observations to obtain an average annual price.

Overall, there were 29 goods for which reliable estimates of prices could be derived: wheat, flour, hay, bran, oats, eggs, socks, salt, codfish, peas, tallow, nails, shoes, savage shoes, lighting oil, firewood, coal, wood planks, beef, butter, lard, religious candles, candles, wine, spirits, cloth, olive oil, soap, sugar and eels. For these 29 goods, there are 2117 potential data points. There was

\footnotetext{
${ }^{93}$ Pierre de Sales La Terrière. 1830. A Political and Historical Account of Lower Canada: With Remarks on the Present Situation of the People, as Regards Their Manners, Character Religion \&c \&c. London: William Marsh and Alfred Miller, p.128; See also Roderick MacKenzie's testimony to the Legislative Council of Lower Canada in 1826 on this issue; Legislative Council of Lower Canada. 1826. Appendix II to the Journals of the Legislative Council of Lower Canada. Unpaginated.

${ }^{94}$ Yvon Desloges. 1991. A Tenant's Town: Québec in the $18^{\text {th }}$ century. Ottawa: Environment Canada Parks Service, p.142.

${ }_{95}$ Fernand Ouellet, Jean Hamelin and Richard Chabot. 1982. "Les prix agricoles dans les villes et les campagnes du Québec d'avant 1850: aperçus quantitatifs" Histoire Sociale / Social History, vol. 15, no. 29, pp.89-90.
} 
at least one observation in 1897 of these (meaning interpolations are only required for the missing $10.4 \%$ ). The method used to compensate for missing data points was as follows. I took the price of these goods relative to that of wheat per five-year period (except for the periods 1688 to 1694 and 1755 to 1760 ) and took the average over the period to complete the gaps. Two goods did not lend themselves to this interpolation method: candles and sugar. Readers are invited to consult Appendix 1 where I provide ample detail about the data and the interpolations.

There were other goods, like tobacco, pepper, apples, middlings, gunpowder, lead, grapes, paper, molasses, barley, vinegar, rice, iron and farm animals which were not reported continuously enough (or there were problems related to quality) to be included in the construction of this price index, but that could, nonetheless, also be instructive. Overall, there were prices for over 120 items, only the best are reported here (more than 15 annual observations). The details of all these items included are available in Appendix 1. Readers are also invited to consult Appendix 3 where I have included a more limited price index based on equal-weights to link up with the estimates produced by Paquet and Wallot between 1760 and 1860 (this is a minor additional contribution from this work, which does not warrant a chapter here and which was more suited for an appendix).

\subsection{How do these prices compare with other prices collected?}

The first test of the viability of the data collected was to determine if they corresponded, at similar levels, with sporadically-reported prices collected by other authors. Wheat prices had initially been collected by Hamelin, but he never reported a table of his figures, making comparison impossible. However, Hamelin used the same source in his work with Fernand Ouellet and Richard Chabot for the period past $1760 .{ }^{96}$ I have extended my collection of wheat prices to 1770 in order to compare with their own prices for which they provided tables. The idea was to determine if the methodological choice made here for collecting prices significantly impacted measurements. As can be seen in Figure 2.2, the direction of price movements is nearly always the same, and the gap is always very small.

\footnotetext{
${ }^{96}$ Fernand Ouellet, Jean Hamelin and Richard Chabot. 1982. "Les prix agricoles dans les villes et les campagnes du Québec d'avant 1850 : aperçus quantitatifs” Histoire Sociale / Social History, vol. 15, no. 29, pp. 83-128.
} 
Figure 2.2. Price of a minot of wheat in Québec City depending on the source, in sols, 1760 to 1770

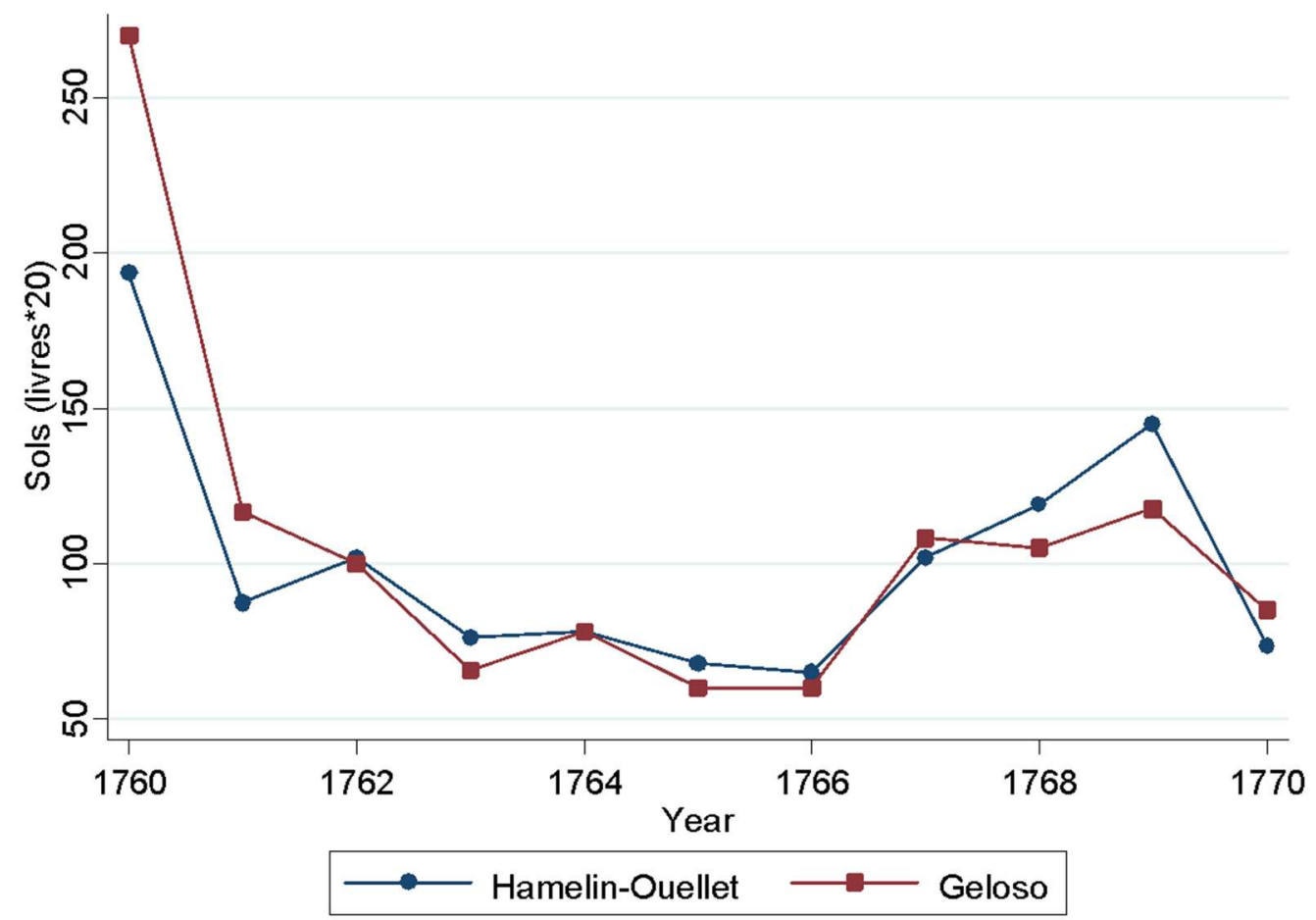

Marc Egnal's collection of prices, taken from the account books of dry goods of a merchant involved in the fur trade, provided the second source. Egnal's data were full of gaps, but provided valuable data points with regard to price information, the most important of which was for textile products, like moltons, shirts, and thread. ${ }^{97}$ These items were not wholly comparable with the ones in this thesis because they were finished products, whereas those in this dissertation are not; they were merely the value of cloth directly, not of manufactured clothing items. They did, nonetheless, provide the researcher with information about the general direction of textile prices. As can be seen in Figure 2.3., prices moved in very similar directions.

\footnotetext{
${ }^{97}$ Marc Egnal. 1998. New World Economies: The Growth of the Thirteen Colonies and Early Canada. Oxford: Oxford University Press
} 
Figure 2.3. Price of textile items (in livres)

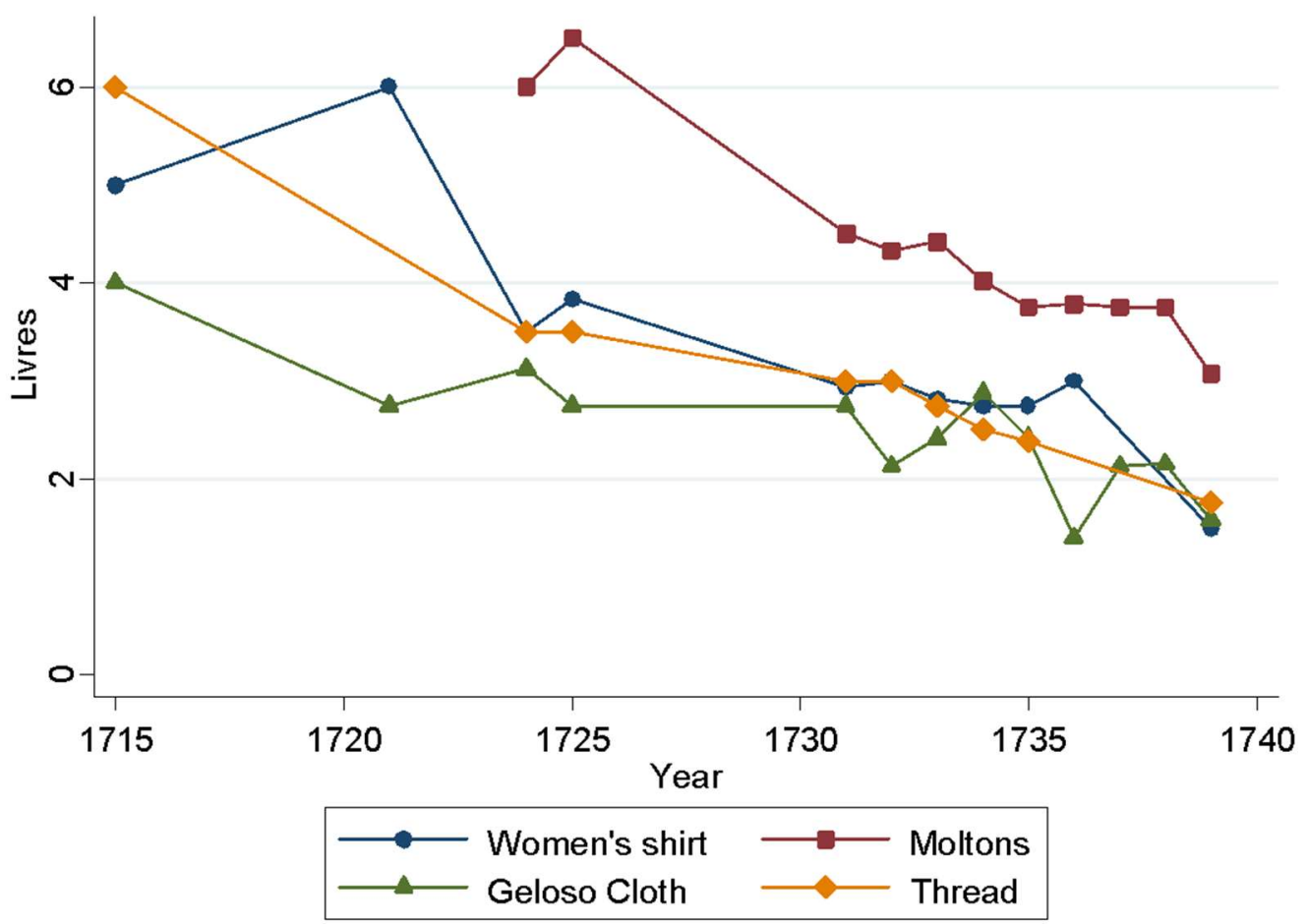

Note: All units are in aunes except shirts which are in units.

It is also possible to compare prices for wood. In his master's thesis from 1973, Claude Richard collected wood prices from the three largest cities of the colony (Quebec, Montreal, TroisRivières) from 1731 to $1752 .{ }^{98}$ Firewood was probably the most essential commodity in Canada. Given the cold weather of the colony, it is often reported that households consumed up to 20 French cords of firewood per year (roughly 48 cubic feet per cord which is less than the English cord). Hence, making sure firewood is properly reported is crucial. The data from Richard confirms that the quality of the data collected for this work is appreciable. The series that concern Quebec City and Three Rivers are not only moving the same way, but they stand at similar levels. In comparison to Montreal, the movements are similar but prices in Montreal are slightly higher.

${ }^{98}$ Claude Richard. 1973. L'industrie du bois en Nouvelle-France au $18^{\text {ème }}$ siècle. Master's Thesis, Department of History, University of Montreal. 
Figure 2.4. Price of a cord of firewood in sols according to Richard (1973) compared to this paper's sources, 1731 to 1752

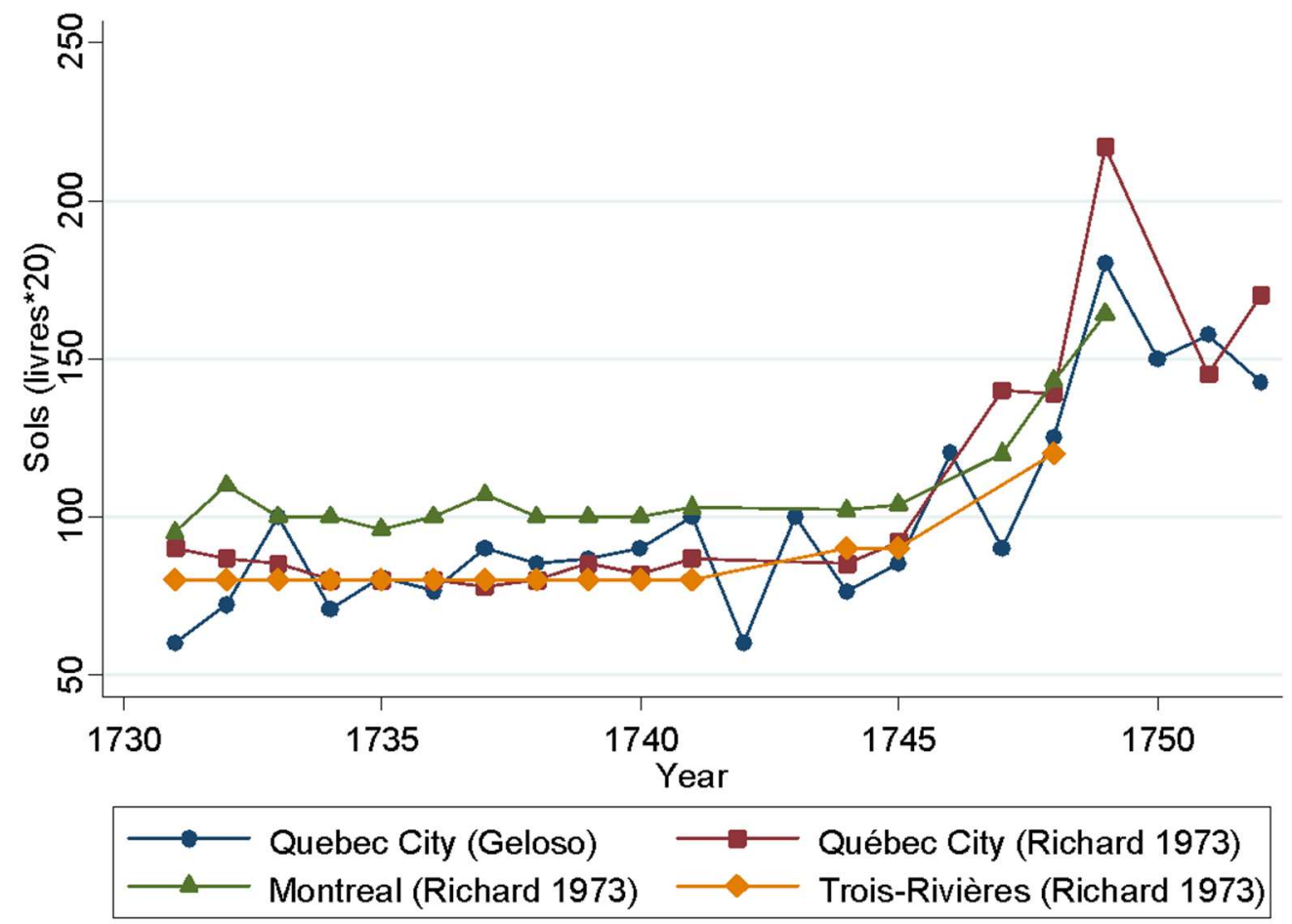

Another manner of comparison requires that I jump ahead a little. In his 1983 monograph on the Augustine congregation which ran the hospital in Quebec City, Rousseau provided elaborate evidence of the expenditures for food and other items that were provided to the poor and the sick in the city of Quebec. ${ }^{99}$ Rousseau aggregated all expenditures in total for certain categories, like food, in order to derive the cost per patient and per ration. Unfortunately, Rousseau never broke down the baskets for numerous items on a year-to-year basis. He merely calculated the price of 100 calories of sheep, bread, peas, and other goods. Hence, it was impossible to truly replicate his work in order to compare price levels and direction. Moreover, there were non-continuous estimates of certain food items over periods of 10 years, but nothing of the sort for non-food items, like nails or clothing.

Rousseau's work, in spite of these limitations, was still very useful for this researcher's purposes. The reason for this was that he provided researchers with an index of the cost of living in the form of the daily cost of room and board. One method of estimating price deflators is to directly measure expenditures per capita for a basket of goods which this researcher knew to have

\footnotetext{
${ }^{99}$ François Rousseau. 1983. L'œuvre de Chère en Nouvelle-France : Le régime des malades à l'hôtel-Dieu de Québec. Québec Presses de l'Université Laval, p.94.
} 
remained more or less constant. As argued by Ralph Turvey, who used expenditures on children at Christ Hospital in London to derive an index similar to that of Rousseau's, such indicators were "not impugned by changes in the composition of expenditure and (...) can be obtained even in the absence of price data." 100 Since the data from Rousseau's work considered the relatively-constant needs of sick patients and religious officials, I deduced that his work was akin to that of Turvey and could be used as an approximation of price movements. If one compares Rousseau's estimations with the ones provided below, one obtains assurances that prices moved in similar patterns and that this validated the quality of the data collected for the purposes of this research.

Figure 2.5. Comparing different measures of prices $(1700=100)$

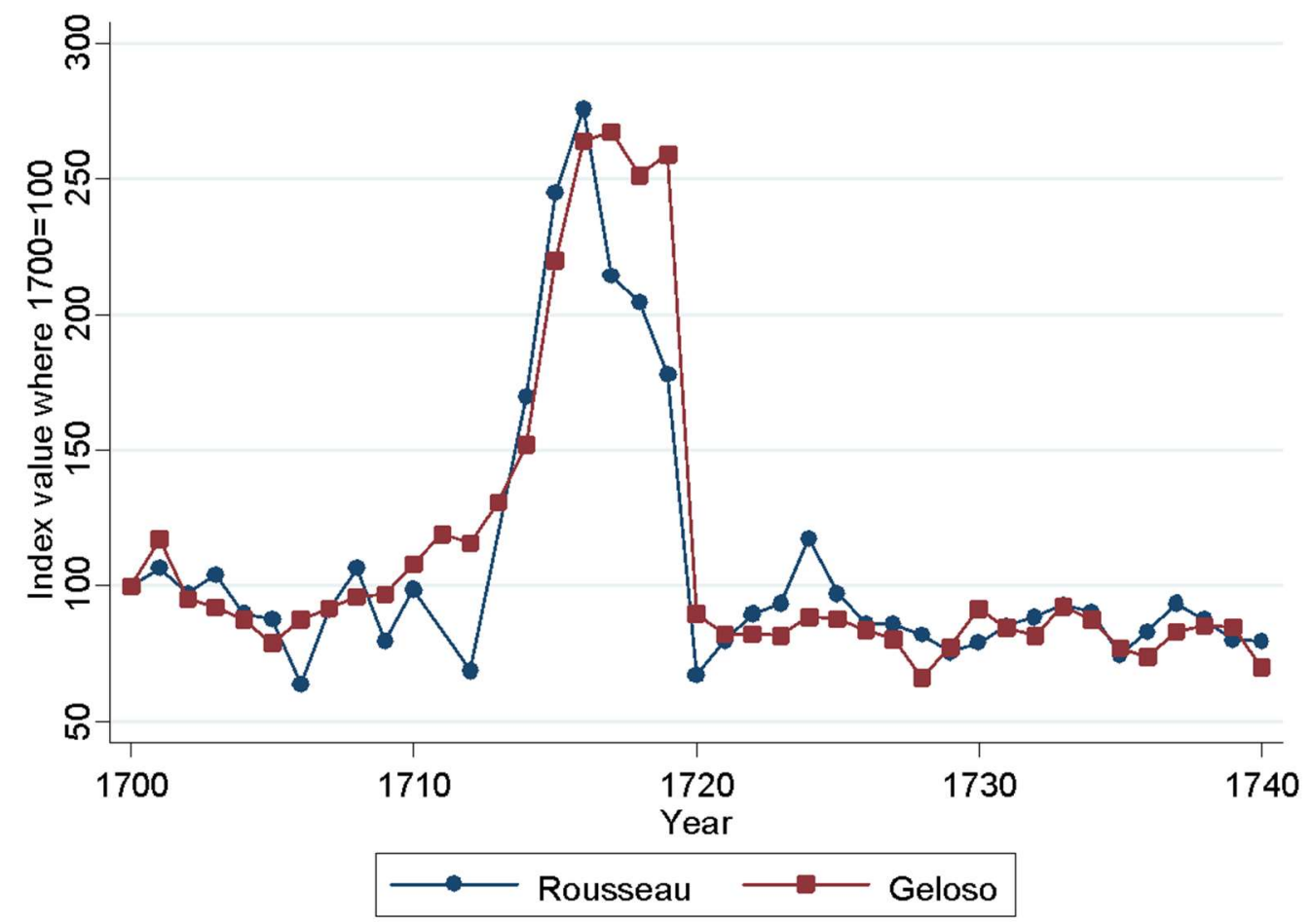

Source : See text later and François Rousseau. 1983. L'œuvre de Chère en Nouvelle-France : Le régime des malades à l'hôtel-Dieu de Québec. Québec Presses de l’Université Laval, p.94.

\subsection{The basket to measure the Cost of Living Index}

The largest problem faced in the creation of a price index for Canada is the absence of weights for household expenditures. This problem was not new in Canadian economic history. It has been the main contention point around the article of Paquet and Wallot (although Appendix 3 to this dissertation documents that their index is not void of interest). With the exception of the

${ }^{100}$ Ralph Turvey. 2010. The Cost of Living in London, 1740-1834. London: Department of Economic History at the London School of Economics and Political Science, p. 2. 
work of Donald Paterson and Ronald Shearer, covering prices from 1840 to 1870, no price indexes for pre-Confederation Canada are weighted. ${ }^{101}$ Paterson and Shearer themselves did not use Canadian weights. They adapted American weights "with reluctance". ${ }^{102}$ The problem with forming a basket with weights relates to its representativeness. Detailed expenditure surveys are not available for New France. What exists relates to the early nineteenth century and concerns only food expenditures.

In a 1992 article, the historian Donald Fyson presented the expenditures for food items that were required to feed workers labouring on the Lachine Canal in the early 1820 s. $^{103}$ Fyson managed to decompose expenditures by categories which have been reproduced in Table 2.2 below. To break down each of the categories he created, I have to rely on some assumptions. It is generally accepted that wheat represented close to three quarters of all grain output in the colony of New France. ${ }^{104}$ Hence, three quarters of the calories from starches came from wheat, whereas the remaining fourth came in equal parts from peas and oats. The remaining items were divided equally between the different items in each of these categories. Fyson also mentioned figures for non-alcoholic beverages, information which I could not replicate. As a result, I had to scale down the measures over the remaining items. Moreover, I decided to split the weight of sugar between salt and sugar. This is because salt was a very common item in the life of the French-Canadians, especially for winters when they needed to salt their lard, eels, and beef, which they consumed in great quantities, according to their contemporaries. Its inclusion was needed.

Some could question the high weight alcohol has in the basket. Yet, there is no reason to disbelieve the proportions advanced by Fyson as one must bear in mind that this is $24 \%$ of food expenditures, not total expenditures. In his work, Rousseau shows that wine and other alcohols represented between $12.7 \%$ and $21.6 \%$ of all food expenditures between 1684 and $1763 .{ }^{105}$ The work of Catherine Ferland also provides reassurance as it suggests imports of wine per person between 1699 and 1754 stood at 14.4 liters and that it was rising throughout the period. ${ }^{106}$ Ferland does not provide equally exhaustive data for tafia and guildive (rums from the French West Indies)

\footnotetext{
${ }^{101}$ Donald G.Paterson and Ronald A.Shearer. 2004. "A history of prices in Canada, 1840-1870: a new wholesale price index", Canadian Journal of Economics / Revue canadienne d'économique, Vol.36, No.1, pp.224-253. In the literature review of this article, there is a discussion of all the other price indexes collected after 1760. As indicated by Paterson and Shearer, there are no indexes of the cost of living based on expenditures baskets.

102 Ibid, p.227.

${ }^{103}$ Donald Fyson. 1992. "Du pain au madère : L'alimentation à Montréal au début du XIXe siècle", Revue d'histoire de l'Amérique française, vol.46, no.1, p.74.

104 Morris Altman. 1983. "Seigniorial Tenure in New France, 1688-1739: An Essay on Income Distribution and Retarded Economic Development". Historical Reflections / Réflexions historiques, Vol.10, No.3, pp.335-375.

${ }^{105}$ François Rousseau. 1983. L'œuvre de Chère en Nouvelle-France: Le régime des malades à l'hôtel-Dieu de Québec. Québec Presses de l'Université Laval, p.67.

${ }_{106}$ Catherine Ferland. 2010. Bacchus en Canada: Boissons, buveurs et ivresses en Nouvelle-France. Montréal: Septentrion, pp.74-75.
} 
or for eau de vie (spirits made from grains) except for a few years in the $1730 \mathrm{~s} .{ }^{107}$ For those years, average per capita consumption of wine, spirits and rums stood on average at 17.9, 0.6 and 14.3 liters per year, respectively. When expressed in monetary terms and then translated as a percentage of total income, alcohol expenditures represented close to $12 \%$ of income per capita as measured by Morris Altman. ${ }^{108}$ If food expenditures represented $60 \%$ of total expenditures (a reasonable assumption as will be shown below), the figure proposed by Fyson is equal to $14 \%$ of income. This figure is quite similar to the numbers obtained by combining the works of Catherine Ferland and Morris Altman.

Since the detailed expenditures advanced by Fyson concern the years 1822-23, it is possible that the basket does not correspond fully to the basket actually consumed in the era of New France. One solution, which may interest future researchers in search of possible contributions, would be to compile notarial records. One type of notarial document is of particular interest, the donation. Normally, the donation was used to transfer ownership of a farm from parents to children while the former were too old to work. However, as Allan Greer pointed out in his work, donations often included pensions for the parents. Greer only reported one donation with a pension. ${ }^{109}$ Collecting a greater number of these would be the ideal topic for a doctoral thesis as expenditures weights could be derived. Although this would be for Canada, it could serve American historians who are also struggling with this problem of poor weights information in the colonial era. However, this dissertation does not make such an attempt given that it would require as much time as collecting the price information required. Down the line, this is a project that future researchers should consider.

\footnotetext{
${ }^{107}$ Ibid, p.88 and p.95.

${ }^{108}$ To get an order of magnitude, in the years available, the average per capita consumption of only the imported wines and rums was worth 14.96 livres (using the prices collected in this dissertation). The prices I collected in this dissertation were for eau de vie which was more expensive than rum (guildive). Rum was the drink of predilection of the general population. I used the ratio of prices (0.463) for rum found in Ferland's work with my own eau de vie prices (for 1733 to 1740, 1744, 1745, 1752, 1753 and 1754) in order to convert my own prices into rum prices. For the years 1732 to 1739, Morris Altman found per capita incomes averaging 127.6 livres (1988. "Economic Growth, Economic Structure and Real Gross Domestic Product in Early Canada, 1695-1739" William and Mary Quarterly, Vol.45, p.702) - meaning that alone, imported wines and rums represented $11.72 \%$ of income.

109 Alan Greer. 1985. Peasant, Lord and Merchant: Rural Society in Three Quebec Parishes, 1740-1840. Toronto: University of Toronto Press, p.35.
} 
Table 2.2. Cost of the basket of food provided to workers on the Lachine Canal in 1822-23 derived from the work of Donald Fyson

\begin{tabular}{ll} 
ITEM & WEIGHT \\
\hline Starches & $37 \%$ \\
Meat & $16 \%$ \\
Dairy products & $7 \%$ \\
Alcohol & $24 \%$ \\
Non-alcoholic beverages & $6 \%$ \\
Sugar & $11 \%$ \\
Others & $1 \%$ \\
\hline
\end{tabular}

Note: The numbers proposed by Fyson did not amount to $100 \%$, likely as a result of rounding up. I merely rescaled to adjusted for this issue (see next table).

Table 2.3. Proposed weights of the basket of food in New France

\begin{tabular}{|c|c|}
\hline ITEM & WEIGHT \\
\hline Starches & $38.54 \%$ \\
\hline Wheat & $28.91 \%$ \\
\hline Peas & $4.82 \%$ \\
\hline Oats & $4.82 \%$ \\
\hline Meat & $16.67 \%$ \\
\hline Eels & $5.56 \%$ \\
\hline Beef & $5.56 \%$ \\
\hline Lard & $5.56 \%$ \\
\hline Dairy products (Butter) & $7.29 \%$ \\
\hline Others (eggs) & $1.04 \%$ \\
\hline Alcohol & $25.00 \%$ \\
\hline Wine & $12.50 \%$ \\
\hline Spirits & $12.50 \%$ \\
\hline Salt & $5.73 \%$ \\
\hline Sugar & $5.73 \%$ \\
\hline
\end{tabular}

Since it is impossible to derive weights that are purely specific to New France in the eighteenth century, alternative weighting schemes must be considered. To assert robustness, one must import the weights of other price indexes for the same time period with reasonable differences with the one used here. The first comparison is derived from the work of Charles Feinstein for England in the late eighteenth century. Using budget data assembled by Eden and Davies, Feinstein created a basket of expenditures for 1788 to 1792, at the eve of the French wars. ${ }^{110}$ These weights were designed for working class households in England at the time. The second set of weights was derived from the work of Peter Solar and Paul David and is probably the most crucial in asserting robustness. ${ }^{111}$ The United States in the early nineteenth century was more or less similar to New France (more so than England). Both economies were land-abundant and labor-scarce (relative to

\footnotetext{
${ }^{110}$ Charles Feinstein. 1998. "Pessimism perpetuated: real wages and the standard of living in Britain during and after the Industrial Revolution", Journal of Economic History, Vol.58, no.3, p.635.

${ }^{111}$ Paul A. David and Peter Solar. 1977. "A Bicentenary Contribution to the History of the Cost of Living in America", Research in Economic History, vol.2, pp.1-81.
} 
Europe). ${ }^{112}$ The third was drawn from Donald Paterson and Ronald Shearer, who had to rely on the commonly-used Warren-Pearson weights derived for the United States since none were present from Canada. ${ }^{113}$ Still, they asserted having made numerous minor adjustments to the weights to insure robustness, which they felt was sufficient. The fourth comes from the work of Winifred Rothenberg, who designed a rural price index for Massachusetts between 1750 and 1855. This last index was also useful, since it made assumptions based on rural patterns of consumption, which differed partly from the weights of the other indexes. ${ }^{114}$

In Table 2.4, the different weighing schemes for the food component of the basket are compared. These are to be compared with those underlined in Table 2.3 and the results are illustrated in Figures 3.6 and 3.7. As one can see from Figure 6, one can feel safe about the validity of the direction followed by the food component in the period up to 1740 . Figure 2.7 shows the price index after 1740 since the price increase observed during the Seven Years War is of such magnitude as to hide any movements prior to that moment. What is important to note is that significant differences in weight specifications do not seem to alter the overall movements of the price index.

\footnotetext{
112 Winifred Rothenberg documents the agricultural activities of rural Massachusetts from 1750 to 1855 at times similar to New France: Winifred Rothenberg. 1981. "The Market and Massachusetts Farmers, 1750-1855" Journal of Economic History, Vol. 41, No. 2, pp.283-314. Numerous authors concerned with Canadian economic history have used this source as a comparison point which confirms in this author's eyes that expenditure weights taken from the United States are considerably important: Douglass McCalla. 1985. "The Internal Economy of Upper Canada: New Evidence on Agricultural Marketing before 1850”, Agricultural History, Vol.59, No.3, pp. 397-416.

${ }^{113}$ Donald G.Paterson and Ronald A.Shearer. 2004. "A history of prices in Canada, 1840-1870: a new wholesale price index", Canadian Journal of Economics / Revue canadienne d'économique, Vol.36, No.1, pp.224-253.

${ }^{114}$ Winifred Rothenberg. 1979. "A Price Index for Rural Massachusetts, 1750-1855” Journal of Economic History, Vol.39, No.4, pp.975-1001.
} 
Table 2.4. Weights used in alternative specifications of the price indexes for foodstuffs

\begin{tabular}{|c|c|c|c|c|c|c|c|c|}
\hline Item & Feinstein & $\begin{array}{l}\text { Geloso } \\
\text { rescaled }\end{array}$ & Item & $\begin{array}{l}\text { Solar } \\
\text { and } \\
\text { David }\end{array}$ & $\begin{array}{l}\text { Geloso } \\
\text { rescaled }\end{array}$ & Item & $\begin{array}{l}\text { Paterson } \\
\text { and } \\
\text { Shearer }\end{array}$ & $\begin{array}{l}\text { Geloso } \\
\text { rescaled }\end{array}$ \\
\hline $\begin{array}{l}\text { Bread } \\
\text { (flour) }\end{array}$ & $20 \%$ & $20.62 \%$ & $\begin{array}{l}\text { Fresh } \\
\text { meats }\end{array}$ & $13.6 \%$ & $13.78 \%$ & Beef & $14 \%$ & $20 \%$ \\
\hline $\begin{array}{l}\text { Wheat } \\
\text { flour } \\
\text { (wheat) }\end{array}$ & $27 \%$ & $27.83 \%$ & Fresh fruits & $4.1 \%$ & $4.15 \%$ & Pork & $14 \%$ & N/A \\
\hline Oatmeal & $13 \%$ & $13.40 \%$ & Flour & $20.2 \%$ & $20.47 \%$ & Butter & $8 \%$ & $19.14 \%$ \\
\hline $\begin{array}{l}\text { Potatoes } \\
\text { (peas) }\end{array}$ & $5 \%$ & $5.15 \%$ & $\begin{array}{l}\text { Cured } \\
\text { meats }\end{array}$ & $26.9 \%$ & $27.25 \%$ & Peas & $1 \%$ & $1.43 \%$ \\
\hline Beef & $3 \%$ & $3.09 \%$ & Fats & $1.7 \%$ & $1.72 \%$ & Tea & $1 \%$ & N/A \\
\hline $\begin{array}{l}\text { Mutton } \\
\text { (eels) }\end{array}$ & $3 \%$ & $3.09 \%$ & Salt & $12.1 \%$ & $12.26 \%$ & Coffee & $3 \%$ & N/A \\
\hline Pork & $7 \%$ & $7.22 \%$ & Sugars & $11.9 \%$ & $12.06 \%$ & Sugar & $8 \%$ & $11.43 \%$ \\
\hline Dairy & $12 \%$ & $12.37 \%$ & Dried fruits & $0.4 \%$ & N/A & Molasses & $1 \%$ & N/A \\
\hline Sugar & $7 \%$ & $3.61 \%$ & Alcohol & $3.2 \%$ & $3.24 \%$ & Flour & $22.5 \%$ & $32.14 \%$ \\
\hline \multirow[t]{12}{*}{ Salt } & & $3.61 \%$ & $\begin{array}{l}\text { Dairy } \\
\text { products }\end{array}$ & $5 \%$ & $5.07 \%$ & Rice & $0.5 \%$ & N/A \\
\hline & & & $\begin{array}{l}\text { Baked } \\
\text { goods }\end{array}$ & $0.9 \%$ & N/A & Fruit & $3.9 \%$ & N/A \\
\hline & & & & & & Salt & $1 \%$ & $1.43 \%$ \\
\hline & & & & & & Olive oil & $0.1 \%$ & $0.14 \%$ \\
\hline & & & & & & Spices & $0.2 \%$ & N/A \\
\hline & & & & & & Potatoes & $6 \%$ & N/A \\
\hline & & & & & & $\begin{array}{l}\text { Milk (see } \\
\text { butter) }\end{array}$ & $3.4 \%$ & N/A \\
\hline & & & & & & Fish & $1 \%$ & $1.43 \%$ \\
\hline & & & & & & $\begin{array}{l}\text { Cheese } \\
\text { (see } \\
\text { butter) }\end{array}$ & $2 \%$ & N/A \\
\hline & & & & & & Tallow & $1 \%$ & $1.43 \%$ \\
\hline & & & & & & Lard & $5 \%$ & $7.14 \%$ \\
\hline & & & & & & Eggs & $3 \%$ & $4.29 \%$ \\
\hline
\end{tabular}

Notes for the Feinstein index: "Oats" took the weight of oatmeal. Since there were no mentions of bread prices with weight quotations in the account books, the researcher for this project attributed the price of flour to bread and the price of wheat to "wheat flour." Potatoes in the Feinstein data were replaced by peas in the current case, since potatoes were not introduced until the conquest of Canada. Eels substituted for mutton for no other reason than that, given the recurrence of its mention as an important form of protein intake in the diets of the Canadians, it would have excluded an important item. A similar logic underlies the choice of dividing the weight for sugar between sugar and salt. Afterwards, the weights were rescaled to account for the missing items. The Feinstein index for the food component does not include alcohol. Some might point to this as a problem, but it is not. Using the Feinstein index of the food component allows me to measure the effect of excluding alcohol which tended to be an imported good. Notes for the Solar and David index: The category "fresh meats" in Solar and David's work contains poultry items, eggs, and fresh meat. The corresponding items in the current study are eggs and beef. The category for "fresh fruits" included potatoes, peas, small fruits, and orchard fruits. I only possessed prices for peas. The category "flour" included cereals and flour. Hence, the weights were equally between flour, oats, and wheat. The category "cured meats" in Solar and David concerns meat products which are canned and smoked fish. In this category, I included eels and codfish which could be considered as cured meats. For the category of fats, Solar and David used only lard, an item whose prices I also had. The share for alcoholic beverages was divided equally between wine and spirits. Dairy products are solely 
represented by butter. Notes for the Paterson and Shearer index: The weights were taken for the period 1855-1870. It was this basket which had the smallest amount of coinciding information with the weights available. Hence, the rescaled weights give a dishearteningly-large weight to flour and beef. However, the results seen below illustrate that even such large problems did not affect the overall trend of the price index.

Table 2.4. (part 2) Weights used in alternative specifications of the price indexes for foodstuffs

\begin{tabular}{lll} 
Item & Rothenberg & Geloso \\
\hline Corn (wheat) & $13.9 \%$ & $13.9 \%$ \\
Hay (combined) & $13.7 \%$ & $13.7 \%$ \\
Potatoes (peas) & $1.2 \%$ & $1.2 \%$ \\
Rye and oats (oats only) & $9.6 \%$ & $9.6 \%$ \\
Dairy products & $23.8 \%$ & $23.8 \%$ \\
Beef (combined) & $14.9 \%$ & $14.9 \%$ \\
Pork (lard) & $13.7 \%$ & $13.7 \%$ \\
Alcohol & $9.1 \%$ & $9.1 \%$ \\
\hline
\end{tabular}

Notes for the Rothenberg index: In the index created by Rothenberg, corn represented $13.9 \%$ of the basket. Since corn was not an important commodity in Quebec until the nineteenth century, it was substituted for wheat. As in the other indexes, potatoes were replaced by peas, since the former were not introduced in Quebec before that time, while peas acted as an important complementary foodstuff. The researcher for this project also combined the weight of oats and rye to better capture the role of oats in the economy of New France. Dairy products were solely represented by butter, whereas the researcher merged the two categories of beef (salted and fresh) in Rothenberg's index. Prices for pork being absent, lard was deemed a reliable substitute. Finally, the ciders mentioned in the Rothenberg paper were merged to obtain a weight which was represented by spirits and wine. 
Figure 2.6. Food price index (1720-1724=100) according to different weight specifications up to 1740

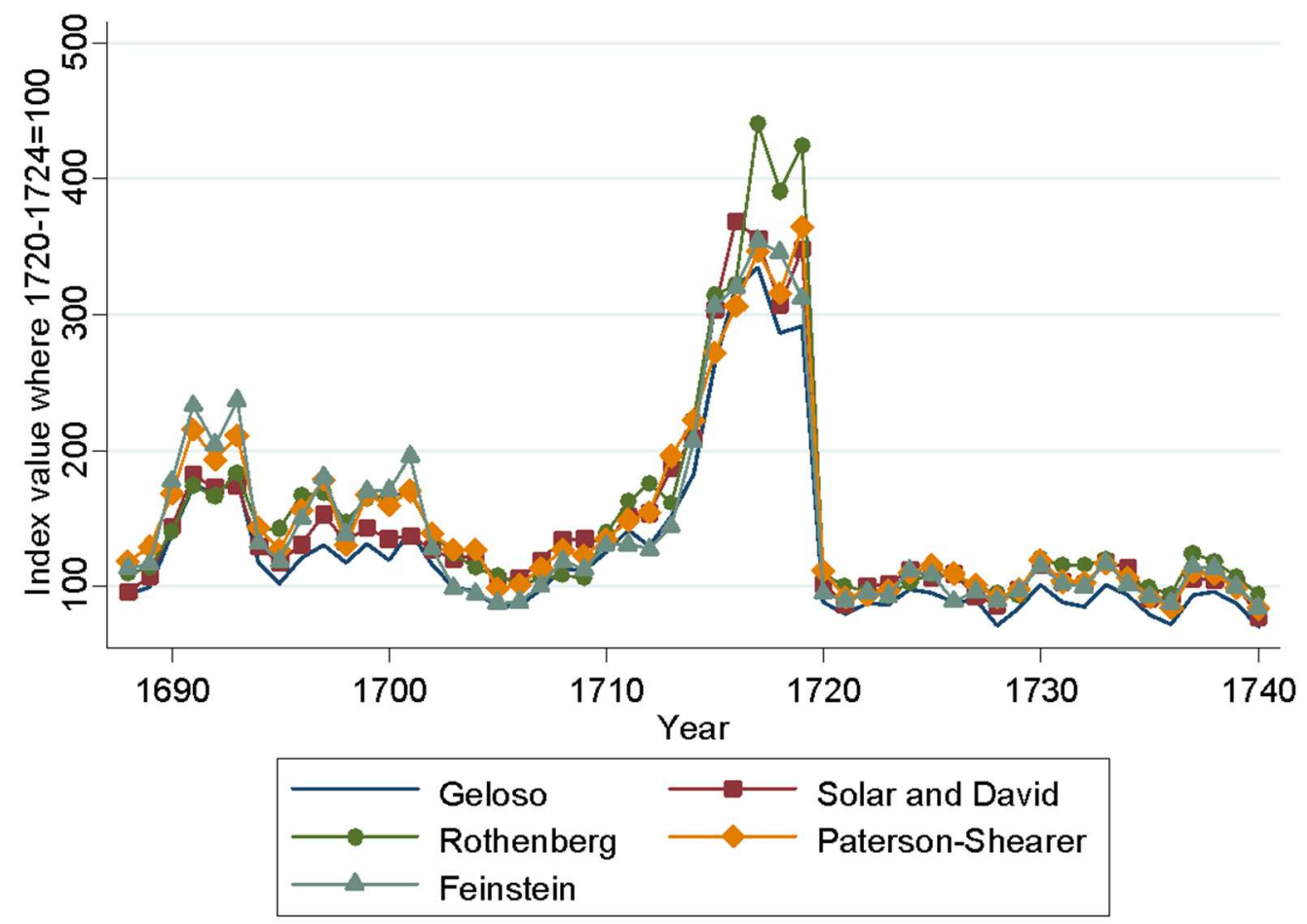


Figure 2.7. Food price index (1720-1724=1) according to different weight specifications after 1740

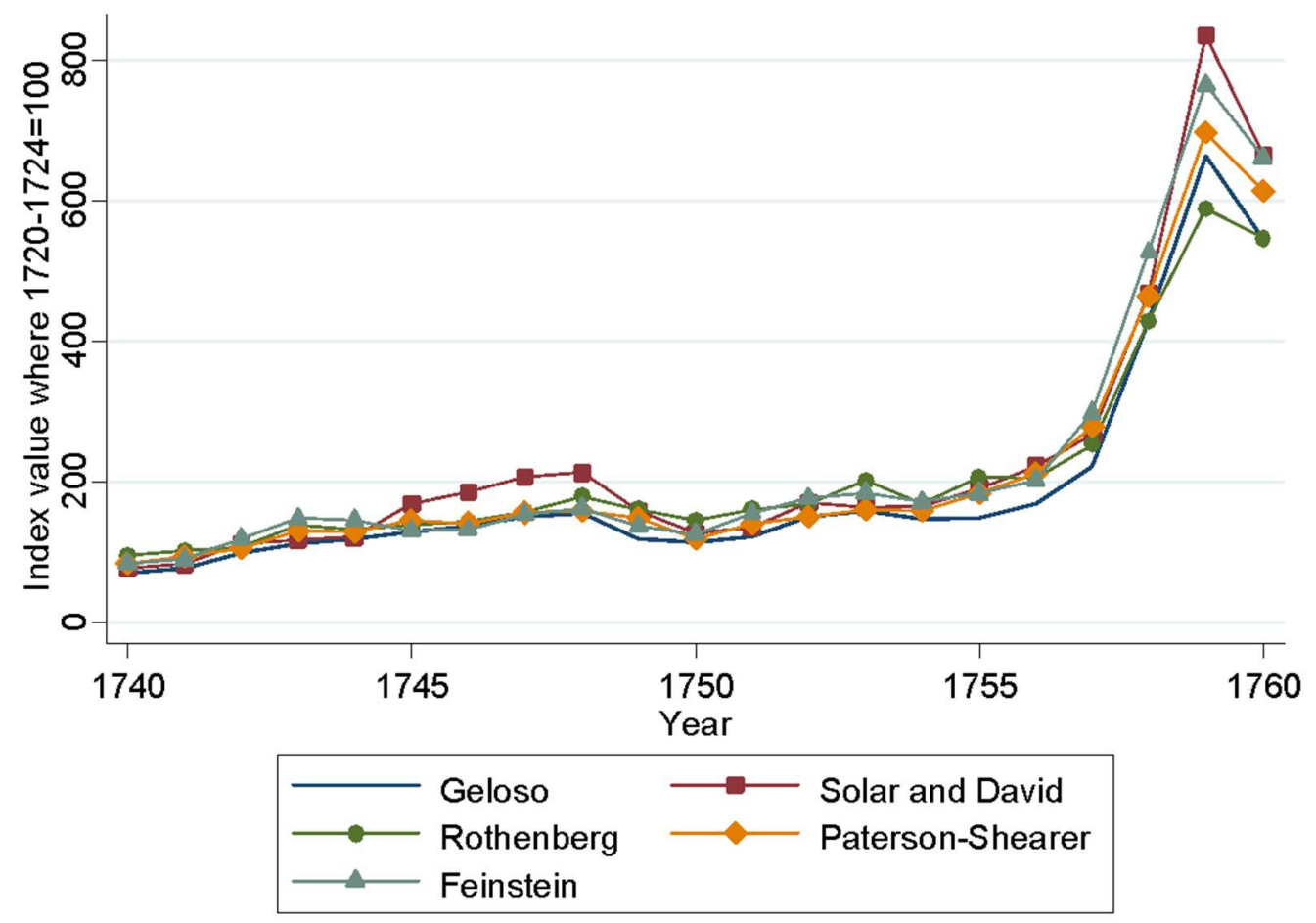

Finding weights for the other components of the basket is problematic. No expenditures studies exist to derive weights with great assurance. There are some pieces of evidence scattered, but not enough to create a definitive basket. From the work of Robert Tremblay, researchers know that poorer workers tended to allocate "roughly" $60 \%$ of their expenses to foodstuffs. ${ }^{115}$ However, Tremblay did not decompose his estimates further and assert that the remaining 40\% were allocated to all the other expenses. In work related to the urban workers of Quebec City between 1820 and 1850, Jean-Pierre Hardy noted that probate records in the city of Quebec indicated that $13 \%$ of all asset values were in the form of cloth. ${ }^{116}$ Meanwhile, David Thiery Ruddel found that this figure for the habitants represented between $12.8 \%$ and $15.8 \%$ of movable assets. ${ }^{117}$ These figures, although they related to movable assets and not to the expenditures basket, are not far from the American estimates provided by Solar and David for the first half of the nineteenth century, in

\footnotetext{
115 Robert Tremblay. 1979. "La formation matérielle de la classe ouvrière à Montréal entre 1790 et $1830 "$, Revue d'histoire de l'Amérique française, Vol.33, No.1, p.49.

116 Jean-Pierre Hardy. 1983. "Niveaux de richesse et intérieurs domestiques dans le quartier de Saint-Roch à Québec, 1820-1850.” Material Culture Review/Revue de la culture matérielle, Vol.17, pp.63-94.

117 David Thiery Ruddel. 1990. "Consumer Trends, Clothing, Textiles, and Equipment in the Montreal Area, 17921835." Material Culture Review/Revue de la culture matérielle Vol. 32, no. 1, pp.45-64.
} 
which they attributed a weight of $21.1 \%$ to clothing items. ${ }^{118}$ The other components of the basket were more difficult to isolate. In the face of limited information, the safest course of action was to use the weights derived by Paterson and Shearer, since they constructed their price index with Canada in mind between 1840 and 1870. It is far from ideal, but at present, it will have to do.

Basically, the food component constructed in Figures 3.6 and 3.7 was given the $59.37 \%$ weight of the total basket proposed by Paterson and Shearer. In short, this index was a composite of the weights detailed in Table 2.3 for foodstuffs with the non-food weights of Paterson-Shearer (henceforth referred to as the Geloso-Paterson-Shearer Composite) in Table 2.5. Figure 2.8 illustrates the comparison of this index with other specifications, including the original PatersonShearer index. Shifting between the weighting schemes of Paterson and Shearer to those of Feinstein and Solar and David does have any significant impact on trends and levels (the weights being detailed in Table 2.5). In any of these cases, appreciable alterations in weights did not alter the story told by the new price index.

As one can now see, prices were relatively stable in peacetime. Most of the important spikes are associated with war years and monetary experiments. From 1685 to 1719, the colonial government experimented with paper money, which caused significant problems of inflation. The scheme was that the colonial administration would sign values on the back of playing cards and use them to pay troops and public expenditures. These issues were supposed to be backed by incoming shipments of gold. At first, the issues were quickly redeemed, but in the 1700 s, they became increasingly unreliable and inflation crept up and after 1714, the situation got out of hand. Most of the large fluctuations seen in the figures below stem from this experiment. New monetary experiments would creep up later during the last years of the French administration when they tried a new, albeit slightly different, paper money experiment which contributed to significant inflation. In Table 2.6, one can see the annual rate of price changes per five-year period. There is sensibly more volatility in the Feinstein index as compared to ours. However, this would largely be the result of the greater importance attributed to food in that index which artificially induces volatility. On the other hand, the Solar and David index moves more in line with my own index in spite of the differences in the weighing scheme.

\footnotetext{
118 Paul A. David and Peter Solar. 1977. "A Bicentenary Contribution to the History of the Cost of Living in America”, Research in Economic History, vol.2, pp.1-81.
} 
Table 2.5. Weighing schemes for the complete basket under alternatives specifications

\begin{tabular}{|c|c|c|c|c|}
\hline & $\begin{array}{l}\text { Geloso-Paterson-Shearer } \\
\text { Composite }\end{array}$ & $\begin{array}{l}\text { Solar and David } \\
\text { adjusted }\end{array}$ & Feinstein adjusted & \\
\hline Food and alcohol & $59.37 \%$ & $51.84 \%$ & N/A & \\
\hline Food & N/A & N/A & $76.67 \%$ & \\
\hline Alcohol & N/A & N/A & $11.11 \%$ & \\
\hline Clothing & $9.41 \%$ & $27.69 \%$ & $6.67 \%$ & \\
\hline Leather products & $4.46 \%$ & N/A & N/A & \\
\hline Housing furniture & $\mathrm{N} / \mathrm{A}$ & $8.53 \%$ & N/A & \\
\hline Fuel \& light & $7.88 \%$ & $9.19 \%$ (fuel only) & $\begin{array}{l}4.44 \% \quad \text { (fuel); } \\
\text { (light) }\end{array}$ & $1.11 \%$ \\
\hline Personal care & N/A & $2.76 \%$ & N/A & \\
\hline Metal products & $7.88 \%$ & N/A & N/A & \\
\hline $\begin{array}{l}\text { Building } \\
\text { materials }\end{array}$ & $10.18 \%$ & N/A & N/A & \\
\hline Miscellaneous & $0.83 \%$ & $\mathrm{~N} / \mathrm{A}$ & $\mathrm{N} / \mathrm{A}$ & \\
\hline
\end{tabular}

Notes for all three indexes: The food components were already described above in Tables 4 and 5. Notes for the Geloso-Paterson-Shearer composite: The category of leather products only considered shoes (savage shoes and French shoes); the category of fuel and light was composed of firewood, candles, and lighting oil; the category of metal products was represented by nails as an indicator for metals; building materials were represented by wood planks, which were used in construction; clothing was represented by cloth and socks; and the miscellaneous category was represented by soap. Notes for the Solar and David weights: Clothing was represented in equal parts by socks and cloth; housing furniture was represented in equal parts by wood planks and nails; fuel was represented by firewood; and personal care was represented by soap. Notes for the Feinstein weights: Alcohol was represented in equal parts by wine and spirits; clothing was represented by socks and cloth in equal parts; fuel was represented by firewood, whereas light was represented in equal parts by candles and lighting oil. 
Figure 2.8. Price index (all goods where 1720-1724=100) compared with alternative specifications

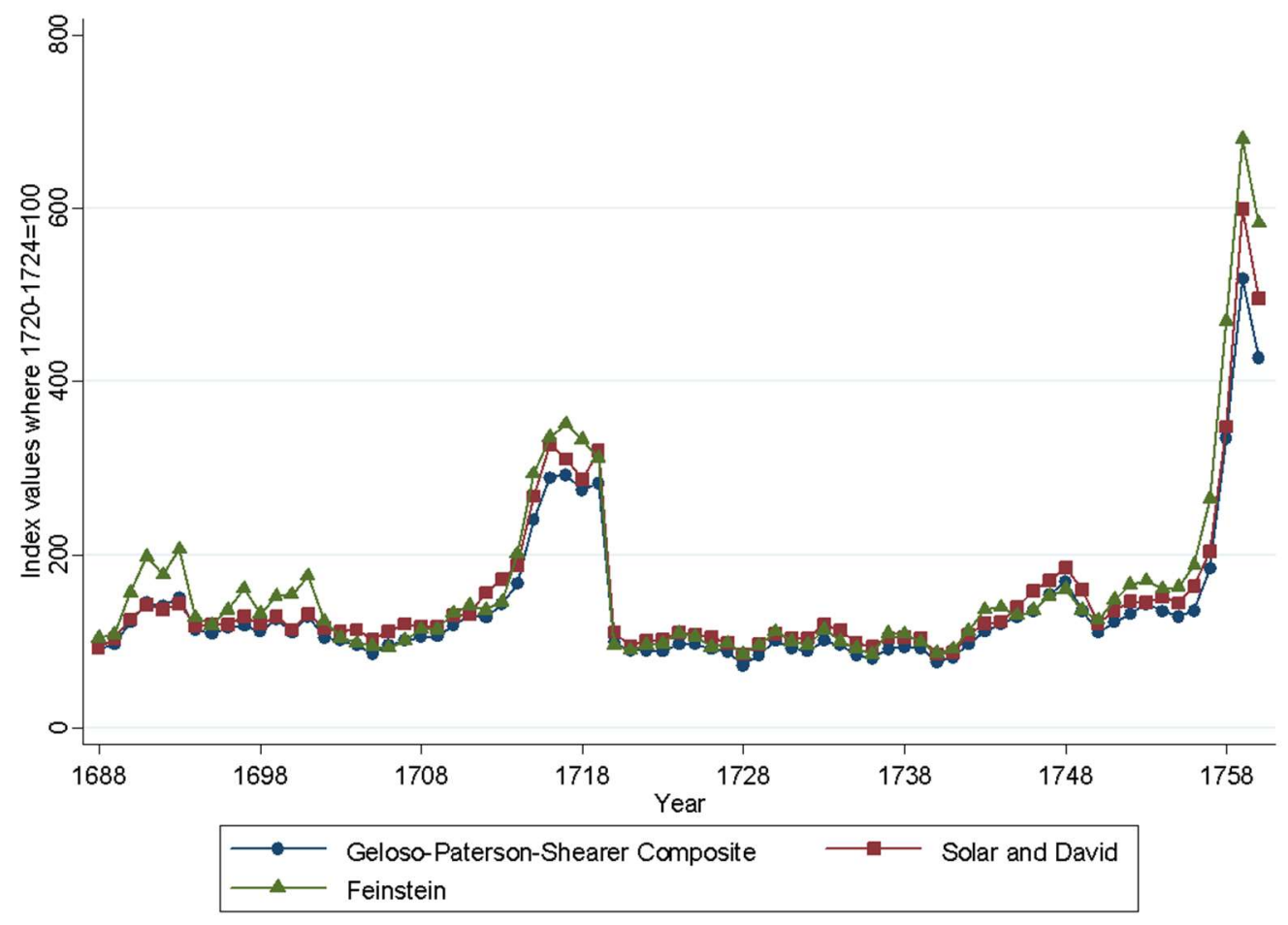

Table 2.6. Annual rates of price change according to the different weighing schemes

Geloso-Paterson-Shearer Composite Solar and David Feinstein

\begin{tabular}{lccc}
\hline $1688-1695$ & $3.6 \%$ & $4.4 \%$ & $5.2 \%$ \\
$1695-1700$ & $-0.2 \%$ & $-0.4 \%$ & $4.1 \%$ \\
$1700-1705$ & $-5.4 \%$ & $-3.4 \%$ & $-6.7 \%$ \\
$1705-1710$ & $3.8 \%$ & $2.5 \%$ & $5.7 \%$ \\
$1710-1715$ & $15.5 \%$ & $15.5 \%$ & $18.6 \%$ \\
$1715-1720$ & $-0.4 \%$ & $-0.3 \%$ & $-2.6 \%$ \\
$1720-1725$ & $-11.1 \%$ & $-11.0 \%$ & $-9.7 \%$ \\
$1725-1730$ & $1.4 \%$ & $0.4 \%$ & $0.9 \%$ \\
$1730-1735$ & $0.5 \%$ & $0.7 \%$ & $0.2 \%$ \\
$1735-1740$ & $-3.2 \%$ & $-4.0 \%$ & $-1.6 \%$ \\
$1740-1745$ & $6.2 \%$ & $6.1 \%$ & $5.4 \%$ \\
$1745-1750$ & $-0.4 \%$ & $0.9 \%$ & $-1.4 \%$ \\
$1750-1755$ & $-0.3 \%$ & $-0.9 \%$ & $3.5 \%$ \\
$1755-1760$ & $25.9 \%$ & $26.5 \%$ & $27.6 \%$ \\
\hline
\end{tabular}




\subsection{Was there inequality in the cost of living?}

To pre-empt some criticisms regarding the quality of the index, in this section, reconstructing the index according to different specifications is necessary. The most important of which was that which concerned inequality. At first, the reader may be wondering how inequality could be a problem relative to other societies. The reason that the researcher considered this was that it relates to the research of Frank Lewis. In frontier economies, like New France at the time, capital formation occurred with land clearing. One individual could save funds, but since there were no banks and very little in the way of capital markets, one could not borrow funds. In order to subsist while land clearing was occurring, large consumption cuts were needed by pioneering households, who drew on their past savings. ${ }^{119}$ As Lewis stated, "a trade-off exists between greater lifetime income and the cost of a less smoothed consumption stream." 120 New households often had to open new lands in the land-abundant, but forested, areas of New France. Important quantities of inputs had to be allocated for clearing. Initially, this would have meant that consumption would have been closer to a bare minimum threshold. Consumption would have increased progressively, as the returns from clearing began to generate higher levels of income. This implies some appreciable disparities between farmers. Assuming that the basket designed above is representative of all farmers in New France would be stretching it. Hence, thanks to land clearing, there would be very different real consumption patterns across the colony. Those who were clearing land at the time would have tended to be lower in the income distribution. Important attention has been allocated, for the economic history of other countries, to the issue of measuring prices for different income groups. ${ }^{121}$ Peter Lindert, who created for eighteenth century Britain a basket of goods representative of certain income groups, can be useful here. For example, Lindert used a share of $55.3 \%$ for food and drinks for the median household, a share of $72.1 \%$ for households in the bottom quintile of income distribution, and a share of $41.8 \%$ for those in the top quintile to consider the fact that individuals tend to attribute a greater share of their expenditures to food as their incomes are lower. ${ }^{122}$ To get an idea of the cost of living at different levels of income and determine if it affects the evolution of prices, the work of Lindert was useful. An index of all items was created based on the figures used by Lindert (see Table 2.6). Although not an ideal measure - using consumption baskets from New France would have been preferable - it is an acceptable proxy. However, there were some problems in replicating the Lindert weights, namely that the "dairy" category contained only butter. For the latter category, I added eggs to the prices so that more items produced from livestock could be considered. This problem seems to be minor,

\footnotetext{
${ }^{119}$ Frank Lewis. 2001. "Farm Settlement with Imperfect Capital Markets: A Life-Cycle Application to Upper Canada, 1826-1851", Canadian Journal of Economics, Vol.34, No.1, pp.174-195.

${ }^{120}$ Ibid, p. 177 .

${ }^{121}$ The best known paper is that of Philip Hoffman, David S. Jacks, Patricia Levin and Peter Lindert. 2002. "Real inequality in Europe since 1500", Journal of Economic History, Vol.62, no.2, pp.322-355.

122 Peter Lindert. 2000. "When did inequality rise in Britain and America", Journal of Income Distribution, Vol.9, no.1, p.22.
} 
since the goal was to determine whether or not changing the weights between food and non-food items to reflect consumption patterns at different levels of income affected the movement of prices in the colony. These problems did not have a large effect on the issue at hand. I also had to rescale to exclude rent.

Table 2.7. Lindert weights, readjustments for this paper and items included per category

\begin{tabular}{|c|c|c|c|c|c|c|c|c|}
\hline \multicolumn{9}{|c|}{ LINDERT } \\
\hline & Bread & $\begin{array}{l}\text { Other } \\
\text { Grains }\end{array}$ & $\begin{array}{l}\text { Meat, } \\
\text { fish, etc. }\end{array}$ & $\begin{array}{l}\text { Milk, } \\
\text { butter, } \\
\text { cheese }\end{array}$ & $\begin{array}{c}\text { Drink and } \\
\text { sugar }\end{array}$ & Fuel, etc. & $\begin{array}{c}\text { Textiles } \\
\text { and } \\
\text { clothing }\end{array}$ & Rent \\
\hline $\begin{array}{c}\text { Bottom } \\
20 \%\end{array}$ & $\begin{array}{c}14.20 \\
\%\end{array}$ & $35.26 \%$ & $12.69 \%$ & $4.97 \%$ & $4.97 \%$ & $7.30 \%$ & $6.40 \%$ & $14.20 \%$ \\
\hline Median & $6.10 \%$ & $15.13 \%$ & $16.62 \%$ & $8.77 \%$ & $8.77 \%$ & $5.80 \%$ & $24.62 \%$ & $14.20 \%$ \\
\hline $\begin{array}{c}\text { Bottom } \\
20 \% \\
\text { without rent }\end{array}$ & $\begin{array}{c}16.55 \\
\%\end{array}$ & $41.10 \%$ & $14.79 \%$ & $5.79 \%$ & $5.79 \%$ & $8.51 \%$ & $7.46 \%$ & $\mathrm{~N} / \mathrm{A}$ \\
\hline $\begin{array}{c}\text { Median } \\
\text { without rent }\end{array}$ & $7.11 \%$ & $17.63 \%$ & $19.37 \%$ & $10.22 \%$ & $10.22 \%$ & $6.76 \%$ & $28.69 \%$ & $\mathrm{~N} / \mathrm{A}$ \\
\hline $\begin{array}{c}\text { Top 5\% } \\
\text { without rent }\end{array}$ & $1.2 \%$ & $2.99 \%$ & $15.75 \%$ & $4.53 \%$ & $9.09 \%$ & $39.47 \%$ & $24.94 \%$ & $\mathrm{~N} / \mathrm{A}$ \\
\hline \multicolumn{9}{|c|}{ GELOSO } \\
\hline & Bread & $\begin{array}{l}\text { Other } \\
\text { Grains }\end{array}$ & $\begin{array}{l}\text { Meat, } \\
\text { fish, etc. }\end{array}$ & $\begin{array}{l}\text { Milk, } \\
\text { butter, } \\
\text { cheese }\end{array}$ & $\begin{array}{l}\text { Drink and } \\
\text { sugar }\end{array}$ & Fuel, etc. & $\begin{array}{l}\text { Textiles } \\
\text { and } \\
\text { clothing }\end{array}$ & Rent \\
\hline Item \# 1 & Flour & Oats & Eels & Butter & Wine & Firewood & Cloth & $\mathrm{N} / \mathrm{A}$ \\
\hline Item \# 2 & Wheat & Peas & Meat & Eggs & Spirits & Oil & Socks & N/A \\
\hline Item \# 3 & & & Lard & & Sugar & & $\begin{array}{c}\text { French } \\
\text { shoes }\end{array}$ & \\
\hline Item \# 4 & & & & & & & Savage & \\
\hline & & & & & & & Shoes & \\
\hline
\end{tabular}


Figure 2.9: Price index (1720-1724=100) with adjustments for inequalities up to 1740

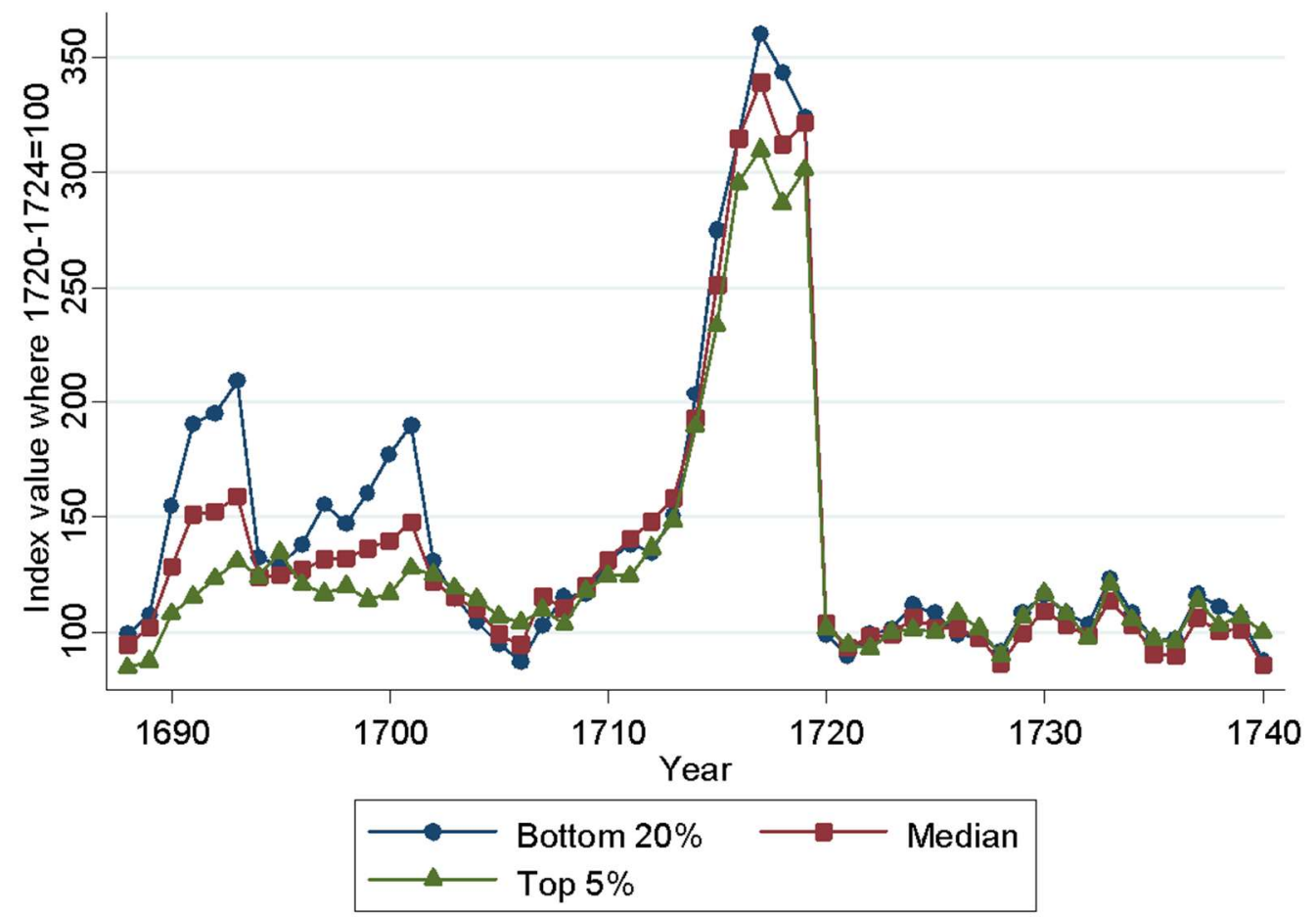


Fig 2.10. Price index (1720-1724=100) with adjustments for inequalities after 1740

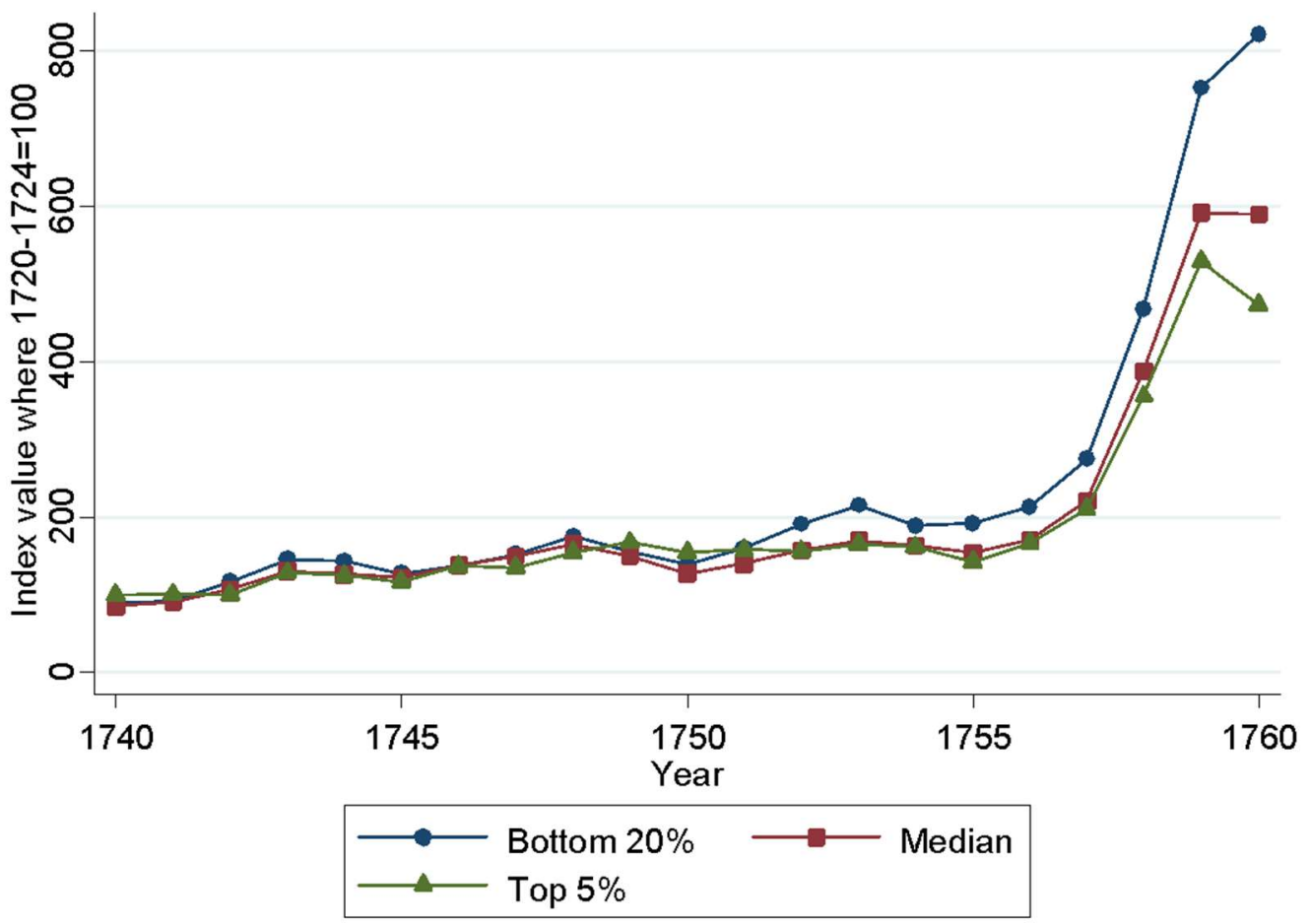

As can be seen in Figures 3.9 and 3.10, the evolution of prices was similar by income group, regardless of the manner in which the index was constructed in periods of peace (17131740), or in periods when the colony was not directly invaded. During the episodes when the colony was invaded (1688-1698, 1701-1713 and 1756-1760), the price level for the poorest went up more significantly. However, the overall trend is not affected and prices converge rapidly. This indicates that the index of the cost of living for the total basket was resistant to changes in specification about weights designed to accommodate the issue of inequality. This author did not believe that this problem was a true one, given the recency of settlement, that land clearing was a steady process for most of the colonists, and that there would not have been significant inequalities. Nonetheless, literature exists that made the claim that Quebec prior to the nineteenth century was a highly unequal society, making this a problem for the validity of price measurements. This author felt it was better to pre-empt this criticism by addressing the issue directly.

\subsection{Comparing prices}

During the period from 1688 to 1720 , prices of imported goods and domestically produced goods moved in similar amplitudes. As a result, the index of the relative price of domestic to imported goods remains more or less stable in 1720 (see Figure 2.11). However, it seems that during the 1720 s, the prices of domestically produced goods began to increase relative to those of 
imported goods and this continues until 1760. The one exception, in the $1740 \mathrm{~s}$, is related to the seizure of the French fortress of Louisbourg in Nova Scotia. The seizure of the fortress meant to protect access to the St-Lawrence seaway threatened maritime trade and the prices of imported goods increased dramatically. They settled back down with the end of hostilities in the 1740s. Secondly, the price experience of New France is not dramatically different than what was observed in the American colonies as can be seen in Figure 2.12. Obviously, the monetary experiment with playing card money in the 1710s and the same experiment in the 1750s which was combined with the violent invasion of the colony make New France stand out relative to the American colonies of Massachusetts, Philadelphia and Chesapeake. However, the logarithmic scale of Figure 2.11 allows us to look at the other periods, especially the long peaceful period with no monetary experiments between 1720 and 1740. In all the colonies, prices exhibit no trend whatsoever. Hence, peacetime is associated with stable prices. However, in wartime it seems that New France experienced more pronounced price increases than the American colonies. Speculations as to the causes of this difference would most likely centre on the role of internal markets and external markets. Thanks to the important population of the American colonies, wartime shocks were less dramatic since there was an internal market upon which to rely (plus the advantages of economies of scale from large population). On the other hand, New France had a very small population and wars would have meant restrained access to foreign markets. For New France, wars would have larger effects on prices. Later, in part 6 of this dissertation, I will return to this issue. 
Figure 2.11. Index of the price of domestic goods relative to imported goods $(1688=1)$

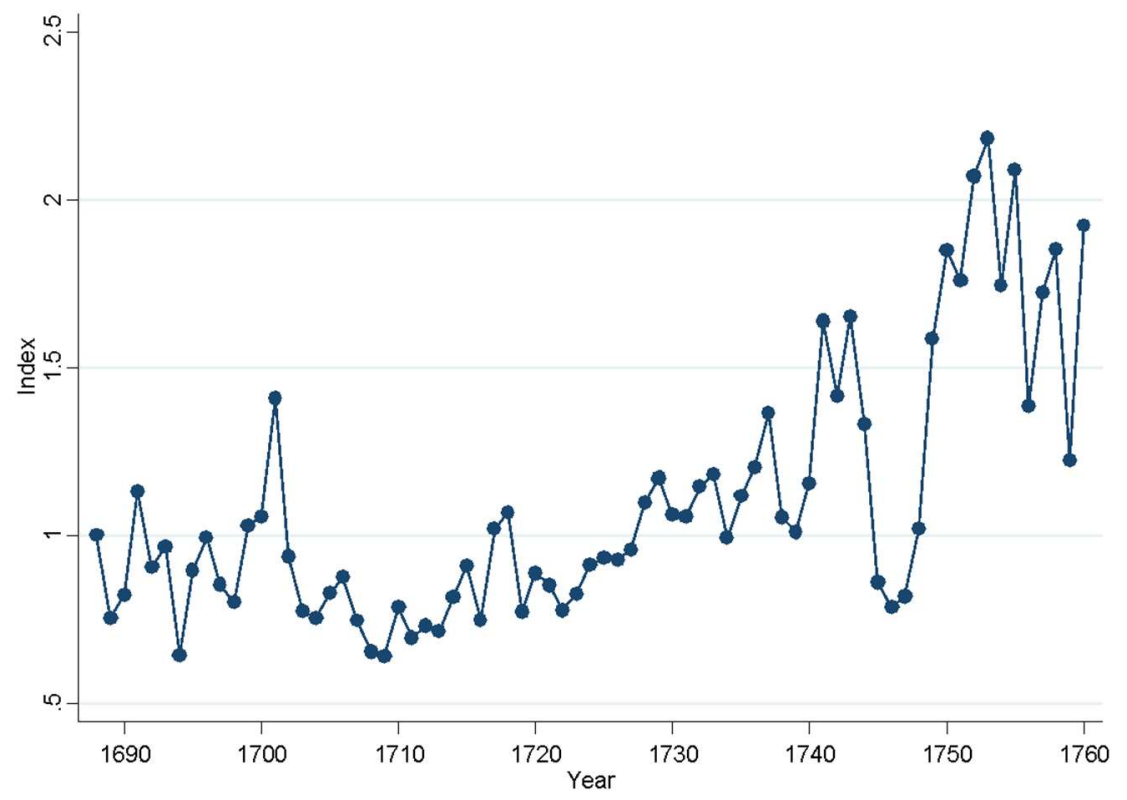


Figure 2.12. Prices in New France, Massachusetts, Philadelphia and Chesapeake (log scale) where $1720-1724=100,1688$ to 1760

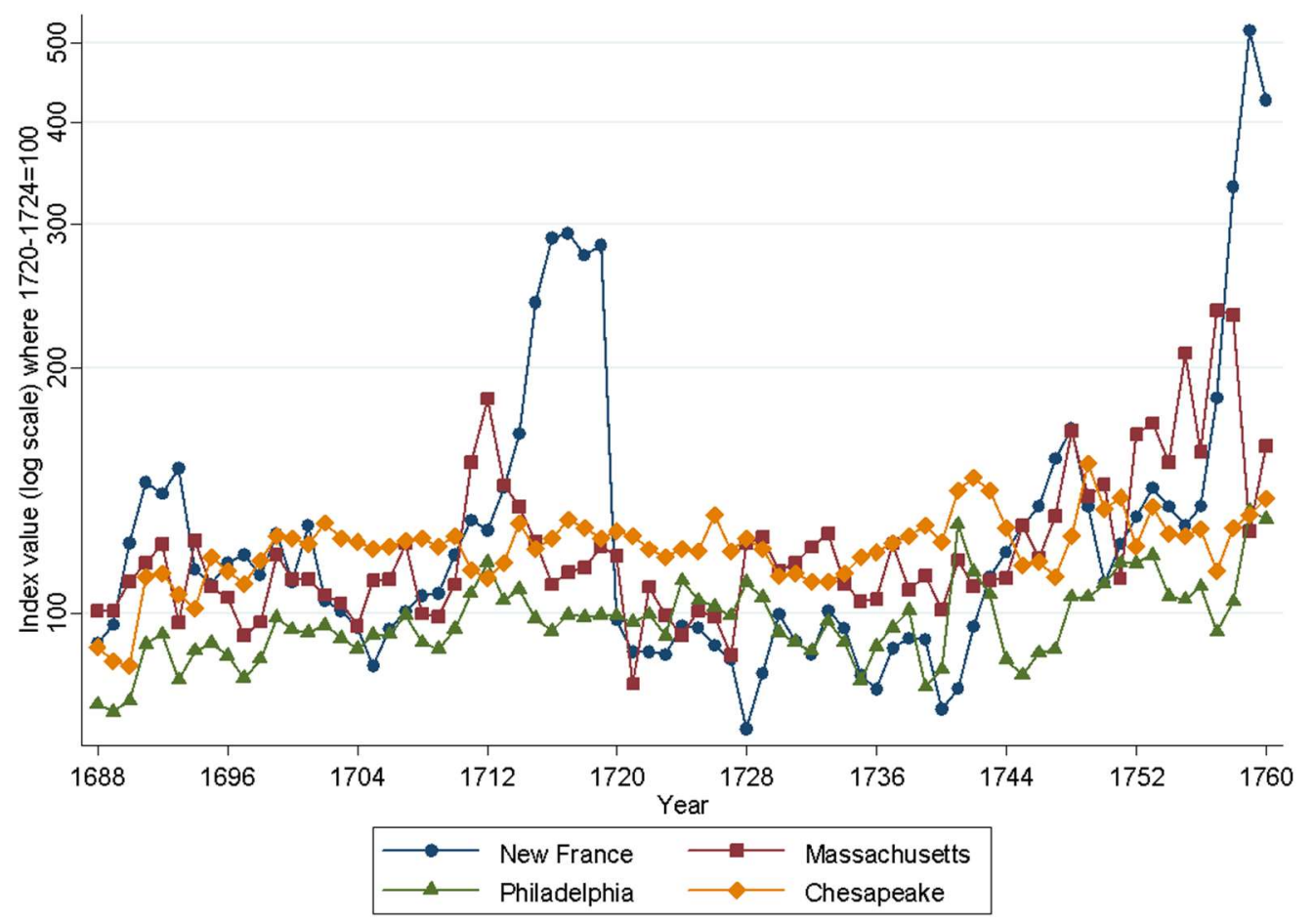

Source: Peter Lindert and Jeffrey Williamson. 2014. American Colonial Incomes, 1650-1774. Cambridge, MA: National Bureau of Economic Research.

\subsection{Conclusion}

The construction of a price index was a crucial first step in the elaboration of a quantitative portrait of New France. Broadly speaking, the index shows great stability except in periods of war and during the monetary experiments with paper money. The index is robust to specification change. However, it is relatively weak on weights - notably the absence of rent data. Although the different likely weights do not alter the trend or the level of prices in New France, the weights are derived from other societies at later points in time. Future research should concentrate on using the donations left with wills at time of death in order to properly devise a basket for Canada. However, this problem is relatively small given the robustness of the results to specification changes.

The first main takeaway is that, now, historians possess a consumer price index by which to deflate wages, incomes, probate records, government expenditures, government revenues, seigneurial duties and individual prices. The second main takeaway is that prices were relatively 
constant in periods of peace with the exception of the monetary experiment with playing cardswhich is a fascinating episode that merits a dissertation of its own. In times of war, prices would move upwards significantly, especially in the last few years of French rule when the colony capitulated to the British. 


\section{PART 3: REAL WAGES AND WELFARE RATIOS}




\subsection{We know so little about living standards!}

As indicated previously, living standards in Canada have been poorly measured and most of the assessment is qualitative or relies on limited quantitative data. The problem concerns not only the trend but also the level of living standards relative to other areas. If there were any colonial origins to Quebec's subsequent divergence from the rest of North America, we cannot know without proceeding with the creation of measurements of living standards.

Some, like Marc Egnal, believe there were no differences in living standards between French Canada and the American colonies at the time. ${ }^{123}$ Cameron Nish supported this hypothesis by comparing New France with Pennsylvania in the 1730s. ${ }^{124}$ Little evidence was marshalled and none accounted for differences in the cost of living. However, Denys Delâge disagreed with such a statement and counter-argued, relying on import and export data, that New France was developing very poorly compared to northern part of the American colonies-chiefly New York. ${ }^{125}$ This claim hinged mostly on fur exports, not on wages, prices or incomes. Comparisons with France are also hard to muster. For example, John Dickinson argued that "salaries were higher [in New France] than those common in France". ${ }^{126}$ However, this claim did not account for purchasing power. Even if we were to take Altman's output per capita figures, we cannot compare them reliably with those for the American colonists. Cutting through the mist of uncertainty requires new data. The goal of this part of my thesis is to do just that: provide new data. The penultimate goal is to include Quebec in the story about divergence by asking the question of whether or not there was divergence within North America as well.

Although it is the main attraction of my dissertation, the real wages (presented as welfare ratios on which I will elaborate below) are not sufficient to generate a full portrait of living standards. As a result, it will be complemented by a GDP series in Chapter 4. Hence, readers should keep in mind that this section is only a first part in the attempt to paint a portrait of living standards. That part is complemented by a second one in Chapter 4.

The method used in this section is the one pioneered by Robert Allen which consists of creating baskets of goods and measuring how many such baskets could be bought given certain wage rates. ${ }^{127}$ Two baskets will be created to generate welfare ratios. The first will be a bare bones basket

\footnotetext{
${ }^{123}$ Marc Egnal. 1996. Divergent Paths: How Culture and Institutions have shaped North American Growth. Oxford: Oxford University Press.

${ }^{124}$ Cameron Nish. 1968. Les bourgeois-gentilshommes de la Nouvelle-France, 1729-1748. Montréal : Fides.

125 Denys Delage. 1970. "Les structures économiques de la Nouvelle-France et de la Nouvelle-York", Actualié économique, Vol.46, No.1, pp.67-118.

126 John Dickinson. 1996. "New France: Law, Courts and Coutume de Paris, 1608-1760" Manitoba Law Review, Vol.23, no.1 p.39.

127 Robert C.Allen. 2001. "The great divergence in European wages and prices from the Middle Ages to the First World War" Explorations in economic history, Vol.38, No.4, pp.411-447.
} 
which will be largely composed of land-intensive goods that would assure the minimum needed for survival. Such a basket is expected to be relatively inexpensive since New France was a frontier economy with abundant, and virgin, farm land. The second basket will be a respectable basket which will include a larger set of imported and capital-intensive goods. This second basket is quite important since, as we will see, it is generally believed that it was easy to "get by" in New France but that moving beyond a certain level of material comfort was a difficult endeavor. This chapter of my thesis will then use the welfare ratios to compare with Paris, Strasbourg, the American colonies, the Latin American colonies and England. The key takeaways are as follows:

A) There was no long term sustained improvement in the living standards of the average individual (defined by an unskilled worker) in the colony from 1688 to 1760 . The same applies if we look at skilled workers;

B) An unskilled worker in Canada was richer than an unskilled worker in France, but only at the bare bones level. At the respectable level, the gap disappears. Skilled workers enjoyed a much greater relative advantage which also dissipates at respectable levels;

C) An unskilled worker in Canada was equally as rich as the unskilled agricultural worker in England at the bare bones level. At the respectable level, this turns into a disadvantage.

D) At the bare bones level, the average inhabitant of Canada was markedly poorer than the average inhabitant of Pennsylvania and New England. At a more respectable level of consumption, the inhabitants of Canada were markedly the poorest in North America.

E) The gap between Canada and the American colonies is nearly the same as the gap observed between Spanish America and the American colonies.

F) Across all categories of capital-intensive goods, the inhabitants of Canada had to work longer than other colonists in North America and France.

\subsection{Linking up with the Allen project}

Any attempt, even in contemporary economics study, to compare living standards across countries can be thwarted by exchange rate problems. ${ }^{128}$ For pre-industrial times, when fewer goods were traded internationally, that problem is considerable. Using exchange rates between two currencies to convert wages and incomes would generate estimation errors between two countries using these currencies. Thus, there is a need to generate an approach based on purchasing power parities - a time-consuming and complex feat to achieve. One way to circumvent this issue is to

\footnotetext{
${ }^{128}$ Bela Balassa. 1964. "The Purchasing-Power Parity Doctrine: A Reappraisal”, Journal of Political Economy, Vol. 72, no.6, pp.584-596; Kenneth Rogoff. 1996. "The purchasing power parity puzzle”, Journal of Economic Literature, Vol.34, no.2, pp.647-668; Jagdish Bhagwati. 1984. "Why are services cheaper in the poor countries?" Economic Journal, Vol. 94, no. 374, pp. 279-286.
} 
rely on an approach built by the World Bank ${ }^{129}$ and introduced into the field of economic history by Robert Allen who adapted them: ${ }^{130}$ welfare ratios.

Put simply, welfare ratios are poverty lines. A bundle of goods and services representative of a certain basic level of subsistence is constructed. Then wages are divided by the cost of that basket to see how large a share of the basket wages can command. The resulting ratio circumvents the issue of purchasing power parities since ratios can be compared over space. This approach was imported into the field of economic history by Robert Allen in numerous articles which were meant to compare living standards across European societies prior to $1913 .{ }^{131}$ Since then, it has been replicated multiple times by other scholars. It was with this method that Peter Lindert and Jeffrey Williamson derived their comparisons of American and British living standards prior to the War of Independence. ${ }^{132}$ Other authors have used welfare ratios to measure living standards in medieval Byzantium, ${ }^{133}$ colonial Spanish America, ${ }^{134}$ late nineteenth century to mid-twentieth century British Africa, ${ }^{135}$ medieval and early modern Italy ${ }^{136}$ and eighteenth century to twentieth century China. ${ }^{137}$ This indicates widespread acceptance in the literature.

However, that acceptance requires caution for four broad reasons. The first reason is that the baskets must be adjusted to use the goods actually consumed. For example, a basket for Southeast China cannot use wheat while the basket for Paris cannot use rice. As a result, the most

\footnotetext{
${ }^{129}$ Martin Ravaillon. 2016. The Economics of Poverty: History, Measurement, and Policy. Oxford: Oxford University Press; World Bank. 1990. World Development Report. Washington D.C.: World Bank Group.

${ }^{130}$ In multiple papers, Allen explains his modifications. However, he assembled them all in this unpublished but publicly available paper: Robert Allen. 2013. Poverty Lines in History, Theory, and Current International Practice. Discussion Paper Series, Department of Economics, Oxford University

131 Robert Allen. 2009. "How Prosperous were the Romans? Evidence from Diocletian's Price Edict (AD 301)" in eds. Alan Bowman and Andrew Wilson, Quantifying the Roman Economy: Methods and Problems. Oxford: Oxford University Press, pp.327-345. This article from Allen provides an efficient example of the justification behind the use of welfare ratios, which we will use later in this paper. However, the key paper is his 2001 paper in Explorations in Economic History (Robert C.Allen. 2001. "The great divergence in European wages and prices from the Middle Ages to the First World War" Explorations in economic history, Vol.38, No.4, pp.411-447).

132 Peter Lindert and Jeffrey Williamson. 2014. American Colonial Incomes, 1650-1774. Cambridge, MA: National Bureau of Economic Research; Peter Lindert and Jeffrey Williamson 2016. Unequal Gains: American Growth and Inequality since 1700. Princeton, NJ: Princeton University Press.

${ }^{133}$ Branko Milanovic. 2006. "An estimate of average income and inequality in Byzantium around year 1000", Review of Income and Wealth, Vol.52, no.3, pp.449-470.

${ }^{134}$ Leticia Arroyo Abad, Elwyn Davies and Jan Luiten van Zanden. 2012. "Between conquest and independence: real wages and demographic change in Spanish America, 1530-1820", Explorations in Economic History, Vol.49, no.2, pp.149-166.

${ }^{135}$ Ewout Frankema and Marlous Van Waijenburg. 2012. "Structural impediments to African growth? New evidence for real wages in British Africa, 1880-1965”, Journal of Economic History, Vol. 72, No.4, pp.895-926.

${ }^{136}$ Paolo Malanima. 2013. "When did England overtake Italy? Medieval and early modern divergence in prices and wages." European Review of Economic History, Vol. 17, no. 1, pp. 45-70.

${ }^{137}$ Joerg Baten, Debin Ma, Stephen Morgan and Qing Wang. 2010. "Evolution of living standards and human capital in China in the $18^{\text {th }}-20^{\text {th }}$ centuries: Evidences from real wages, age-heaping and anthropometrics", Explorations in Economic History, Vol.47, No.3, pp.347-359.
} 
commonly used basket of goods in the literature, the bare bones basket, is designed to capture the most inexpensive forms of subsistence. That implies obtaining calories and nutrients from the cheapest food items at a level designed to insure the meanest form of survival (thus the use of the term bare bones). Baskets in Paris and London will use oats while baskets in Beijing and Kyoto will use rice and baskets in Latin American cities use maize. To do so, once must study carefully the actual diets of the population and be sure that the prices included in the indexes are representative of the goods actually consumed. Moreover, quantities must be adjusted to reflect the environmental conditions. Workers in tropical climates require fewer calories than workers in colder climates and thus a bare bones basket would include fewer calories in Brazil than in Canada. Additionally, fuel requirements for cooking and heating would also be greater in the latter than the former. These are crucial adjustments to be discussed and weighed against alternatives.

A second reason relates to the role of the length of the work year. The most frequent assumption is that workers supplied 250 days of work per year. This can affect both trends and comparisons. The work of Stephen Broadberry et al. on economic growth in Britain from 1270 to 1870 has made this clear, since real wages and output per capita can move differently depending on distributional shifts or on labor inputs supplied. ${ }^{138}$ This affects the trend. The second issue is that the length of the work year can be shorter in one area relative to another. For example, Lindert and Williamson found that welfare ratios measured based on wages (multiplied by 250 days) were much higher in Colonial America relative to England than those based on actual incomes (but they were still higher). ${ }^{139}$ This issue explains the presence of Chapter 4 of this dissertation. To circumvent this limitation, a GDP index is computed to measure income per capita.

A third reason relates to the issue of family size. In his initial work, Allen assumed a family of four (two parents, two children) which meant three adult equivalents. This assumption is not too problematic if family size does not vary considerably over space. However, there were important differences during the era that concern us since families in the New World tended to be considerably larger than those in the Old World. ${ }^{140}$ In fact, even within Europe there were significant differences whereby the Irish had close to one more individual per household on average than the English at the beginning of the eighteenth century. ${ }^{141}$ Larger families mean a different adjustment of the basket to capture living standards (because there are economies of scale as size grows). This affects the comparison. However, as will be shown below, measuring output

\footnotetext{
138 Stephen Broadberry, Bruce M.S. Campbell, Alexander Klein, Mark Overton and Bas van Leeuwen. 2015. British Economic Growth, 1270-1870. Cambridge: Cambridge University Press.

139 Peter Lindert and Jeffrey Williamson 2016. Unequal Gains: American Growth and Inequality since 1700. Princeton, NJ: Princeton University Press, pp.68-69.

140 Jean-Louis Flandrin. 1979. Family in Former Times: Kinship, Household and Sexuality. Cambridge: Cambridge University Press, p. 55.

141 Mason Bradbury, Nils Peterson and Jianguo Liu. 2014. "Long-term dynamics of household size and their environmental implications", Population and Environment, Vol. 36, no.1, pp.73-84.
} 
per capita offers a simple solution for that point. Again, readers should bear in mind that Chapters 3 and 4 are complementary and linked to one another as each attempts to compensate where the other is weakest.

The fourth reason relates to the use of a bare bones measure. Once basic survival is achieved, consumers do not simply consume more goods of the "bare bones" category. For example, rather than eating oats, they might shift to wheat, peas, more meat or more complex goods (like using oats and barley for beer and spirits). ${ }^{142}$ Thus, there is a need for a more elaborate measure of consumption. In his work, Allen tackled this issue by designing a "respectable basket" which included more calories, proteins, fuel, clothing and lighting. One such basket will be conceived here. However, this step wears a special importance for the Americas given relative prices. In Europe, labor was abundant and land was scarce. In the New World, the opposite was true. As a frontier economy, the high land-to-labor ratio meant relatively low prices for foodstuffs. ${ }^{143}$ However, imported and manufactured goods would have been dearer. Bare bones baskets rely heavily on food items that would have been grown and produced domestically and given the relatively low prices of these goods, achieving basic subsistence would have been fairly easy. However, obtaining a more comfortable level of living would have been harder given the need to import or manufacture goods in this land-abundant, labor and capital scarce economy. Comparisons at the bare bones level might overstate differences in actual living standards and thus the creation of a respectable basket is crucial.

\subsection{Wage data for New France}

To solve the problem of poor knowledge about wages, I collected observations of wage rates in the account books of the Séminaire de Québec and the Ursulines de Québec. These are the same congregations as those described in the previous chapter. Both congregations possessed a wide array of installations that provide us with observations from numerous areas, the most important being wages for farm work. The Séminaire possessed several farms and mills in the area of Quebec City: la Canardière, la Petite Ferme Saint-Joachim, la Grande Ferme Saint-Joachim, le Petit Pré, Saint-Michel and Baye Saint-Paul. It also possessed a large estate north of Montreal on the Isle Jésus. The Ursulines operated numerous farm estates on the southern shore of Quebec City. Moreover, it operated several shallow-draft ships which were used to carry goods between the different installations that it owned-providing us with wages in the transport sector. To all of these, one must add observations of skilled workers (carpenters who built and repaired buildings) and domestics who are frequently mentioned. The data provided by the Séminaire is rich with

\footnotetext{
${ }^{142}$ Another example is that oats tended to be fed to horses in England while it was the main item in Scottish diets before the eighteenth century.

${ }^{143}$ Peter Lindert. 2016. Purchasing Power Disparity before 1914. Cambridge, MA: National Bureau of Economic Research.
} 
information about numerous sectors of activity. Thus, it gives us a glimpse into the labor market of the time.

When I collected the data, I recorded the observations by noting the wage rate per unit of time, and then I took notes about the nature of the trade involved, noted the person's name and the page within each reference. It is important to indicate that I noted the name in order to make sure I did not count them twice. In numerous accounts, gages (wages and earnings) are reported for journées, mois and an (daily, monthly and yearly). In all, I recorded 1119 wage observations. Of those, 584 are observations about daily wages, 133 are on a monthly basis and 402 are annual observations. These observations span from 1688 to 1760. Figure 3.1 provides the breakdown for each type of wage rate on an annual basis. The period from 1724 to 1730 is somewhat disappointing since the account book that was concerned with that period was very poor with regard to wage information; hence the sample of wages is most problematic in that sub-period.

Figure 3. 1. Breakdown of wage observations per type of frequency in each year

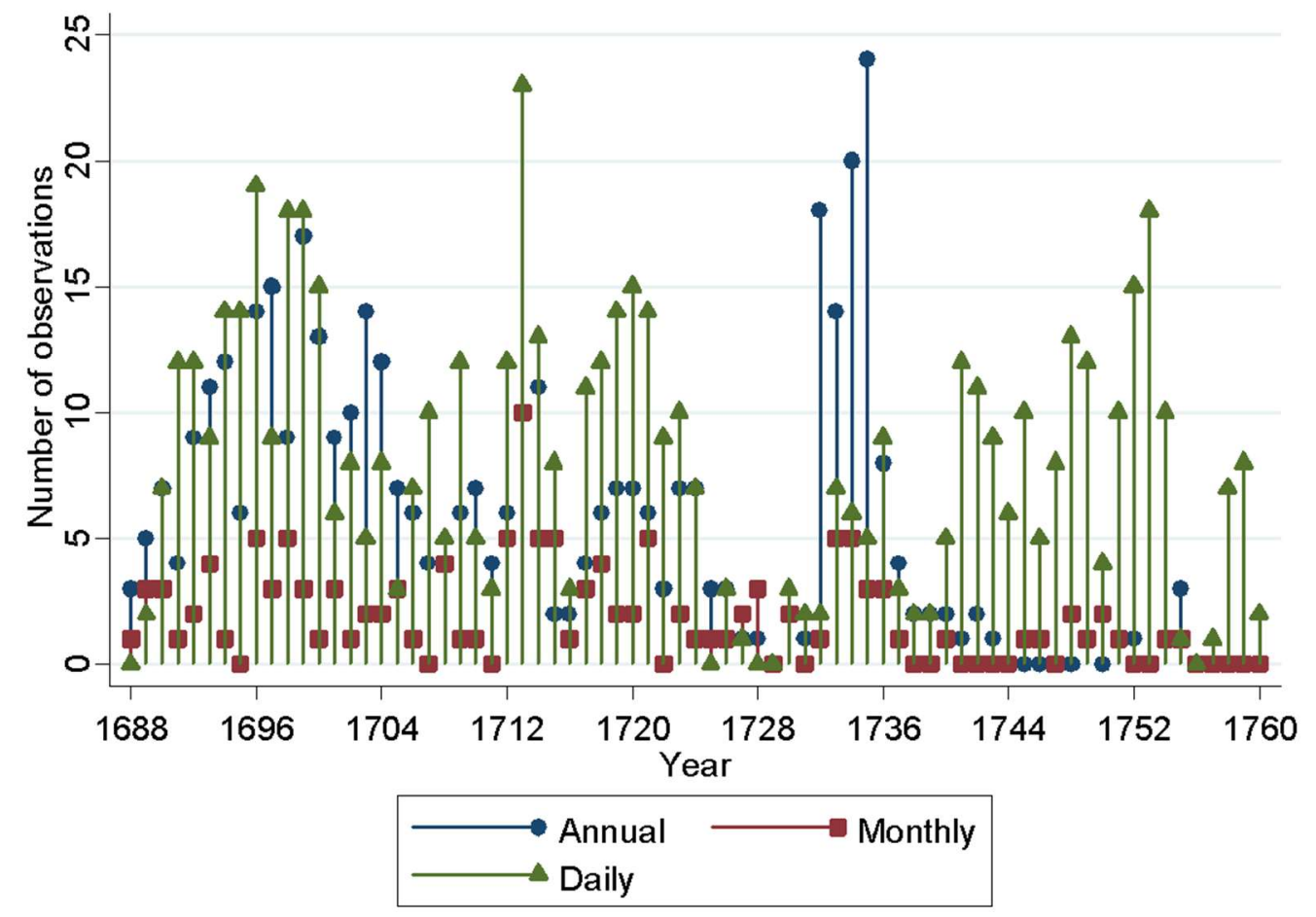

Daily wages are the most valuable data points collected since they are the cleanest and those needed for deriving welfare ratios. Very rarely were those wages associated with payment in kind, so there are very few problems of underestimated wage levels. When they received in-kind payments, the account books added the notice of "et nourry" (and fed) to the wage rate or mentioned a specific item that was offered. In those instances, the Séminaire also reported the 
value of the payments in kind that were offered. I only collected daily wages when I could surmise or infer with confidence what the nature of the contracted work was. While some occupations remained unspecified however; the rates they report are often the same as some of the same activities reported in a given year. For example, a given individual could be paid 20 sols for travail aux foins (harvest) and one line below, he would be paid 20 sols for his journée de travail (day of work) without specification. In such situations, I made inferences with regard to the nature of the work contracted. The daily wage observations are those that will be the most useful for the purpose of measuring living standards. The idea is that the wage rate represents adequately the earnings of a given socio-economic group (that of the farmers) and also provides an indicator of productivity growth. ${ }^{144}$

Annual wages are more problematic. Sometimes, the account books are specific as to the nature of the work that was contracted. However, this was not always the case. Often, the account books would report that an individual had signed a three-year contract for a wage rate of 120 livres per year without any mention of what he was to do. In some occasions, I found mention of this contract with hints of numerous various occupations from farm work to repairs to carrying wood and wheat. Annual observations are hence very hard to decipher because little is known about what the nature of the work was. Moreover, we do not always know the precise value of the payments in kind that were associated with these contracts. As a result, I collected numerous unspecified observations about engagement contracts. At the beginning, I collected all engagement contracts that I could find but I reconsidered the value of doing so since the unspecified contracts varied wildly. I have only kept annual observations whose nature could be ascertained. Engagement contracts were not the sole form of labor contract that could exist in New France. As we move further into the eighteenth century, mentions of annual wages paid to millers, brewers and blacksmiths are found. These wages are well reported with mentions of whether or not the contracting parties agreed to some form of payments in kind.

One considerable advantage with the Séminaire data is that it is a good proxy for wages across the colony. Normally, economic historians tend to be skeptical of how religious account books recorded wages that might have been above the average level of wages because religious estates were more productive. In the case of New France, one could point out that religious congregations held estates that were settled earlier than most farms in the colony. Hence, these estates would have had exhaustive land clearing in the past and be closer to their peak level of productivity. However, the archives of the Séminaire provide us with sufficient information to see

\footnotetext{
${ }^{144}$ As Robert Allen and al. put it: "Our knowledge of labour market conditions and the extent of regional migration seem to substantiate the view that wage rates may serve as a reasonable proxy for the average earnings of a particular socio-economic group as well as the marginal productivity of labour in the economy as a whole". Robert Allen, JeanPascal Bassino, Debin Ma, Christine Moll-Murata and Jan Luiten Van Zanden. 2011. "Wages, prices, and living standards in China, 1738-1925: in comparison with Europe, Japan and India", The Economic History Review, Vol.64, no.S1, p.29.
} 
that this was not the case and that it is a broadly representative set of lands to be used to mimic the behaviour of wages in the whole of New France. This is mostly because the land-clearing patterns are consistent with what was happening in the colony as a whole. Remember that wages were collected from all the different estates of the Séminaire. For example, waves of concessions to new farmers on the St-Ferréol estate were still being made in the 1750s and 1780s which indicates that there were still improvements to be made. ${ }^{145}$ One of the main estates, the Île Jésus was only conceded to the Séminaire in $1702 .{ }^{146}$ And that concession was only finalized in $1704 .{ }^{147}$ Additionally, land clearing was very slow. According to Sylvie Dépatie, peasants on the estate of the Île Jésus owned by the Séminaire cleared land at the pace of roughly 2 to 3 arpents (1 arpent $=0.845$ acre) per year while the average censive (farm plot) was roughly 110 to 150 arpents. ${ }^{148}$ Moreover, a large share of the wage observations collected are related to land clearing tasks like draining ditches, removing the rocks in a newly opened plot, building the fence and removing trees. This provides appreciable assurance about the validity of those wage rates with respect to the economy as a whole.

This fact reflects well the dominant sector of the economy: agriculture. Until the midnineteenth century, close to $80 \%$ of the population was employed partially or totally in agriculture. ${ }^{149}$ The vast majority of the estates were not located in Quebec City, but in farm areas many kilometers outside the city (some were less than 10 kilometers away, many were roughly 30 kilometers away, others were more than 80 kilometers away). As a result, the price and wage data collected concerned agricultural areas specifically, and the nature of the occupations associated with the reported activities were largely agricultural. Thus, the sample created avoids the problem of being too narrow by centering only on urban centres (when the colony was ruralizing rather than urbanizing). ${ }^{150}$ Data showing higher wages in the cities would represent confirmation of the

145 ASQ-Répertoire des titres, Saint-Ferréol

${ }^{146}$ ASQ_SMES/1/15e-Brevet de confirmation de la concession de l'Île Jésus au Séminaire de Québec.

147 ASQ_SMES/1/15d_L'abbé Jean-Frs Buisson de St-Côme demande au Conseil Souverain l'enregistrement de la concession et du Brevet de confirmation de la concession de l'Île Jésus au Séminaire de Québec.

148 Sylvie Dépatie. 1988. L'évolution d'une société rurale : l'Île Jésus au XVIIIème siècle. Montréal, PhD Thesis, Department of History, McGill University, p.198.

149 Public Archives of Canada. 1876. Volume IV of the 1871 Census of Canada. Ottawa: Department of Agriculture, p.21-63.

${ }^{150}$ I must state that I do not believe that this would have been a problem for the case at hand even if my data had been purely urban. Like the United States to the south, Quebec was a frontier economy in which land was abundant. Cheaply available land meant that moving to virgin soils in the countryside was picking low-hanging fruit (Peter Lindert and Jeffrey Williamson 2016. Unequal Gains: American Growth and Inequality since 1700. Princeton, NJ: Princeton University Press, pp. 57-58). In the United States, this meant ruralisation (or de-urbanisation) whereby the urban share of the total population grew smaller. The same trend was observed in Quebec. While the share of the population in cities was well above that of the American colonies, it was falling from census to census. In 1688, the proportion stood at $25.80 \%$ against $21.52 \%$ in 1739 and $20.59 \%$ in 1784 (Public Archives of Canada. 1876. Volume IV of the 1871 Census of Canada. Ottawa: Department of Agriculture pp. 22-23, 60, 75). By definition, this would have implied small gaps in real wages between cities and the countryside that did not offset the non-economic costs of living in cities. This is exactly what Lindert and Williamson found for the United States. In 1774 a northern unskilled worker in a city earned only $7.1 \%$ more than an unskilled worker in rural areas. Given that the censuses of Canada suggest 
rural nature of my dataset, however, for prices, the differences would depend on the goods. Items produced in the hinterland of Quebec would tend to be more expensive in the city as they would have to be shipped from outside cities. Items imported from abroad or manufactured inside the city would tend to be more expensive in the countryside than in the city. Since Quebec City was the main port of entry, imported goods would be cheaper there. One source dealing explicitly with urban areas, the colonial administration located inside Quebec City which often hired workers and bought supplies for these workers and the local garrison, offers the necessary validation. A series of well-documented government reports between 1742 and 1745 provide the strong comparison seen in Table 3.1. Domestically produced goods like grains, butter and meats were dearer in the city than in the countryside. Imported goods (with the notable exception of wine) cost more in the countryside than in the city. Wages were also lower in the countryside than in the city. In fact, it was not only the mean wage rate that was lower in rural areas, but the range of wage rates also tended to be higher in the city. Thus, the results in Table 1 demonstrate clearly that my dataset represents rural information.

that the rural share of the population in Canada increased just as it did in the United States, similarly small wage gaps are to be expected in Canada. 
Table 3.1: Average price (1742, 1744, and 1745) and wage differences (1742 to 1745) between urban and rural areas

Price differences between urban and rural areas for domestic goods

\begin{tabular}{lcc}
\hline Wheat & $7.8 \%$ \\
Beef & $13.9 \%$ \\
Lard & $35.4 \%$ \\
Peas & $36.8 \%$ \\
Flour & $26.8 \%$ \\
Oats & $42.7 \%$ \\
Butter & $36.2 \%$ \\
Firewood & $22.3 \%$ \\
\hline Price differences between urban and rural areas for imported goods & \\
\hline Salt & $-19.7 \%$ \\
Pepper & $-19.4 \%$ \\
Wine & $25.3 \%$ \\
Burning Oil & $-16.7 \%$ \\
\hline Wages (unskilled workers) & \multicolumn{3}{c}{} \\
\hline Year & \multicolumn{3}{c}{ daral (this dissertation's } \\
1742 & Urban & $(20-30) / 21.25$ \\
1743 & $(25-30) / 27.92$ & $(20) / 20$ \\
1744 & $(22.5-29) / 26.36$ & $(20-30) / 23.37$ \\
1745 & $(21.17-25.75) / 23.25$ & \\
\hline
\end{tabular}

Source: Library and Archives Canada, numerous microfilms associated with Série C11A. Correspondance general; Canada (R11577-4-2)

Note: The range for wages is in brackets.

Ultimately, our goal is to create welfare ratios as are commonly used by numerous economic historians. Some might question not only the reliability of the source, but even the reliability of wage rates. Normally, economic historians like Paul Bairoch tend to believe that wages can be used an indicator of Gross National Product (GNP). ${ }^{151}$ However, this claim can be disputed on the basis that pre-industrial economies have wage rates that are not fully representative of the broad economy. ${ }^{152}$ And indeed, in the case of New France, some could make the claim that wages are not fully representative and might induce a wrong representation of the economy. Alan Greer pointed out that the average worker "with earnings coming in during only part of the year, would be hard-pressed to maintain himself at the even most basic level in the long run". ${ }^{153}$ Summarizing

${ }^{151}$ Paul Bairoch. 1989. "Wages as an Indicator of Gross National Product" in eds. Peter Scholliers, Real Wages in $19^{\text {th }}$ and $20^{\text {th }}$ century Europe: Historical and Comparative Perspectives. New York: Berg Publishing, pp.51-60.

152 Dietrich Ebeling. 1989. "Some Remarks on the Relationship between Overall Economic Output and Real Wages in the Pre-Industrial Period" in eds. Peter Scholliers, Real Wages in $19^{\text {th }}$ and $20^{\text {th }}$ century Europe: Historical and Comparative Perspectives. New York: Berg Publishing, pp.61-66.

${ }^{153}$ Allan Greer. 1997. The People of New France. Toronto: University of Toronto Press, p.56. 
the seminal works of Richard Harris and Louise Dechêne, Greer points out that since selfemployment as a farmer was the dominant choice, there would have been no such thing as a "free market" for labour. ${ }^{154}$ I have already outlined why I believe that the wage statistics collected from the Séminaire are representative of the marginal productivity of labour and representative of average earnings. ${ }^{155}$ Moreover, it would be shortsighted to assume that peasants were working exclusively in one sector. Market exchanges were always an open option for the habitant farmer. Even if he chose not to trade his labor on the market, he could always do so at the prevailing price - which was reflective of the marginal product of labor. In fact, they needed to work for the non-farm sector to complement their incomes. Obviously, farming would tie workers to their farms to some extent, but farming alone would not sustain very high living standards. In the neighbouring economy of Upper Canada, it was estimated for the early nineteenth century that in "the absence of a second source of farm income, workers would not have chosen to migrate [to farming] even if, in the long run, farm income would have been more than three times the nonfarm alternative". However, when a second source of income becomes available, farming becomes a viable alternative when the "nonfarm income was as high as one half of long-run farm income". ${ }^{156}$ Peasants would thus complement their income by working elsewhere. However, some readers might still be left unconvinced by my theoretical claim. Hopefully, numerous observations about the nature of work in Canada support this contention of mine. This is because wage rates for the unskilled were very often paid for occasional work. For example, Jacques Mathieu mentions that most skilled workers would often complement their income performing tasks unrelated to their trade. ${ }^{157}$ In the off seasons - since the winters were very long in Canada ${ }^{158}$ _ peasants would often look for work to complement their income. Some would venture into the fur trade, ${ }^{159}$ but one very important activity in winter consisted of cutting down and harvesting wood. ${ }^{160}$ There are mentions in the wage data collected of individuals being paid for cutting down trees outside the harvest period. Otherwise, some peasants could work for the Séminaire at a determined wage rate until they had paid off their tithe obligations which they could not meet-something noted by Sylvie

\footnotetext{
154 Ibid, p.56.

${ }^{155}$ In this work, Robert Allen and al. offer justification of such a claim: Robert Allen, Jean-Pascal Bassino, Debin Ma, Christine Moll-Murata and Jan Luiten Van Zanden. 2011. "Wages, prices, and living standards in China, 1738-1925: in comparison with Europe, Japan and India", The Economic History Review, Vol.64, no. S1, p.29.

${ }^{156}$ Lance Davis and Stanley Engerman. 1999. "The Economy of British North America: Miles Traveled, Miles Still to Go" The William and Mary Quarterly, Vol.56, No.1, p.14.

157 Jacques Mathieu. 2001. La Nouvelle-France : les Français en Amérique du Nord, XVIe-XVIIIe siècle. Québec : Presses de l'Université Laval, p.99.

158 Thomas Wien. 1990. "Les travaux pressants : calendrier agricole, assolement et productivité au Canada au XVIIIe siècle" Revue d'histoire de l'Amérique française, vol.43, no.4, pp.535-558.

${ }^{159}$ Morris Altman. 1988. "Economic Growth, Economic Structure and Real Gross Domestic Product in Early Canada, 1695-1739" William and Mary Quarterly, Vol.45, p.685.

160 Jacques Mathieu. 2001. La Nouvelle-France : les Français en Amérique du Nord, XVIe-XVIIIe siècle. Québec : Presses de l'Université Laval, p.93.
} 
Dépatie. ${ }^{161}$ In other instances, some peasants would work on the farms of the Séminaire to settle outstanding debts they had with the congregation. ${ }^{162}$ In other instances, a peasant would work on the farm of the estates for a short period of time to acquire the capital necessary before settling on his own plot - capital which would be used to finance consumption while the land was being cleared. ${ }^{163}$ Others would also combine the activity of land clearing on their own plots with some form of wage earning for the congregation. This is broadly confirmed by the fact that the account books of the Séminaire list creditors and debtors. The debtors were farmers who possessed the lands owned by the Séminaire and had to pay the seigneurial dues like the cens et rentes and the lods et ventes (more on those later). Very often, these same debtors were found as creditors a few pages later or even right on the next page when they were paid for menial tasks related to construction, farming, land clearing and transporting items. Therein lies the second advantage of the Séminaire and Ursulines dataset: the daily wage observations are not associated with a negative premium that workers would have endured in order to have steady employment. The vast majority of work contracted was complementary and represented closely the marginal productivity of labor. This argument does not exclude the possibility that some workers accepted a lower rate in order to become a steady part-time worker for the congregation, but I have found no evidence supporting such a claim. Overall, I feel confident that I can use the wage rates I collected to measure living standards.

However, I am aware that some might fail to be convinced by my theoretical claims and the evidence I accumulate in this section. This is why I will heed the call made by Phelps-Brown and Hopkins who constituted the celebrated builders' wage series for England from the thirteenth century to the early twentieth century. ${ }^{164}$ Wages are not sufficient to derive conclusions about incomes without knowing about labour supply, a point whose importance was well illustrated in the work of Stephen Broadberry and al. when they showed that the increases in labour supplied in Britain while real wages were stagnant hided increases in real incomes. ${ }^{165}$ Hence, I will provide a longer discussion in the next chapter which will attempt to solidify the claims I make. Skeptical readers should bear their criticisms until the next chapter.

\footnotetext{
161 Sylvie Dépatie. 1988. L'évolution d'une société rurale : l'Île Jésus au XVIIIème siècle. Montréal, PhD Thesis, Department of History, McGill University, p.92.

162 Ibid, p. 105.

${ }^{163} \mathrm{Ibid}$, p.189. Note: It ought to be mentioned that this point is broadly consistent with that made by Frank Lewis concerning the farm economy of Upper Canada in the early nineteenth century whereby individuals would take temporary work in order to finance their consumption once they had acquired a unit of land which needed to be cleared. Frank Lewis. 2001. "Farm Settlement with Imperfect Capital Markets: A Life-Cycle Application to Upper Canada, 1826-1851", Canadian Journal of Economics, Vol.34, No.1, pp.174-195.

${ }^{164}$ E. H. Phelps-Brown \& Sheila Hopkins. « Seven Centures of the Prices of Consumables, Compared with Builders' Wage-Rates », Economica, 1956, Vol. 23, No 92, p. 296-314.

165 Stephen Broadberry, Bruce M.S. Campbell, Alexander Klein, Mark Overton and Bas van Leeuwen. 2015. British Economic Growth, 1270-1870. Cambridge: Cambridge University Press, p.248-250.
} 
There is also another problem of which I am fully aware. Workers could have sacrificed important monetary sums to obtain stable employment. In short, adjustments in the economy could have occurred through religious congregations and other firms who reduce the quantity of labour employed rather than reduce wages. Workers who desired full-time employment as wage-earners would have probably been ready to pay a penalty in the form of a lower daily wage rate in order to obtain stable year-round employment. Economic historian John Hatcher made such a point abundantly clear in the case of England, showing that quantity of labor employed varied more significantly than wages indicating that quite a lot of workers would have accepted the trade-off of lower wages for stable employment. ${ }^{166}$ Judy Stephenson has also made a similar point in recent research, as well as Jane Humphries and Jacob Weisdorf. ${ }^{167}$ If this point is correct, daily wage rates might get the long-term trend of living standards correct, but not the level. Monthly workers or annual workers would have had lower daily wage rates, but due to the stability of employment, they would have had a higher income.

This problem is not as big as some might believe, but it is not small either. Workers hired annually are generally found in the censuses as "domestics"-a broad term that not only encompassed domestics proper but also cooks and farm help. ${ }^{168}$ Outside of these individuals, only colonial administrators would earn wages on an annual basis. The 1762 census of Trois-Rivières district reported that $6.6 \%$ of the population of that district was engaged as domestics. ${ }^{169}$ That region proposes a distinctively high level and probably represents the highest level of the entire colony. The 1762 census of the Quebec district, in which the Séminaire and the Ursulines were located, reported a much lower level of domestics relative to the population- $2.83 \%$. ${ }^{170}$ Dépatie reported that in the case of Montreal with the census of 1765 , domestics represented $4.4 \%$ of the population of the eleven concerned parishes. ${ }^{171}$ In addition, the vast majority of those hired as domestics were very young and used to supplement family income. ${ }^{172}$ According to Louise

\footnotetext{
${ }^{166}$ John Hatcher and Mark Bailey. 2001. Modelling the Middle Ages: The History and Theory of England's Economic Development. Oxford: Oxford University Press.

167 Judy Stephenson. 2014. Gilboy revisited: or low(er) wages and the pre-industrial London building craftsman. Communication presented at the Economic History Society 2014 conference in Warwick; Jane Humphries and Jacob Weisdorf. 2016. Unreal Wages: A New Empirical Foundation for the Study of Living Standards and Economic Growth in England, 1260-1860. Oxford: Working Paper no. 147 of the Discussion Papers in Economic and Social History at the University of Oxford.

168 Sylvie Dépatie. 2008. "Maîtres et domestiques dans les campagnes montréalaises au XVIIIe siècle : bilan préliminaire", Histoire, économie \& société, Vol.27, no.4, p.52.

169 Gouvernement du Québec. 1947. Rapport de l'Archiviste de la Province de Québec pour 1946. Québec : Bureau de l'archiviste, pp.1-51.

${ }^{170}$ Gouvernement du Québec. 1926. Rapport de l'Archiviste de la Province de Québec pour 1925-6. Québec : Bureau de l'archiviste, pp.1-32.

171 Sylvie Dépatie. 2008. "Maîtres et domestiques dans les campagnes montréalaises au XVIIIe siècle : bilan préliminaire", Histoire, économie \& société, Vol.27, no.4, p.53.

172 Arnaud Bessières. 2008. "Le salaire des domestiques au Canada au XVIIe siècle" Histoire, économie \& société Vol.27, no. 4, p.43.
} 
Dechêne, the average age of servants in the late seventeenth century in the Montreal area who were born in Canada stood at 15 years old. ${ }^{173}$

What is left of annually employed workers were immigrants. In the seventeenth century, these were known as engagés who signed 36-month contracts. The recruiting organization had to pay for the individual's travel to New France, a cash advance and committed itself to housing, clothing and feeding that individual. In exchange, that individual would work on numerous tasks. ${ }^{174}$ While indentured servitude did play a large role in the settling of America, it failed to attain the same role in New France. Most of the settlers were often unwilling participants, or deportees, or soldiers who chose to remain. ${ }^{175}$ In the eighteenth century, the majority of those who came did so unwillingly as faux-sauniers - petty criminals who would have been convicted for smuggling, selling of untaxed salt and poaching. ${ }^{176}$ Many of these faux-sauniers simply escaped thereafter to the American colonies, others were drafted into the defensive military forces of the colony while the remaining individuals signed contracts with the inhabitants to work as farm help. The vast majority was usually engaged in similar tasks to those they performed on the old continent—cooks, millers, gardeners, etc. ${ }^{177}$ However, as we will see in Chapter 6, immigration was a very small flow throughout the history of the colony. Only a fraction of that small flow of immigrants would come as engagés or domestics, the rest would be filles $d u$ roy, soldiers (many of whom would settle down) and administrators. As a result, I do not believe that this issue is problematic. For the truly skeptical, I should point out that Chapter 5 of this dissertation will construct a measure of income per person in order to see if the level is misestimated. As we will see, the results are not affected in their levels relative to the American colonies nor the general conclusion that there was no growth.

There is also another key feature of the labor market that must be mentioned: New France had no guilds. ${ }^{178}$ There was an "absence of guilds and an exclusive" that allowed apprenticeship to freely "respond to the needs of the labor market". ${ }^{179}$ There were no prescriptions on the terms of contracts, allowing contracts to be individualized. In fact, free apprenticeships were not unheard of. ${ }^{180}$ In the absence of guilds, we are hence observing relatively undistorted wages in which the skill premium is not predicated on artificially-induced scarcity. However, this was true only for

\footnotetext{
${ }^{173}$ Louise Dechêne. 1974. Habitants et Marchands de Montréal au XVIIe siècle. Paris : Plon, p.362

174 Jacques Mathieu. 2001. La Nouvelle-France : les Français en Amérique du Nord, XVIe-XVIIIe siècle. Québec : Presses de l'Université Laval, p.71.

175 Peter Moogk. 1989. "Reluctant Exiles: Emigrants from France in Canada before 1760", William \& Mary Quarterly, Vol.46, No.3, pp.463-505.

176 Ibid, p.498.

177 Josianne Paul. 2008. Exilés au nom du roi: les fils de famille et les faux-sauniers en Nouvelle-France, 1723-1749. Montréal : Éditions du Septentrion, p. 153.

178 Peter Moogk. 1971. "Apprenticeship indentures : A key to Artisan life in New France" Historical Papers / Communications Historiques, Vol.6, No.1, pp.65-83.

${ }^{179}$ Ibid, p.65.

${ }^{180}$ Ibid, p.67.
} 
skilled trades like masons, carpenters, shoemakers, barrel-makers and joiners. ${ }^{181}$ The colonial government created entry restrictions on the trades of butchers and bakers. For example, in the district of Montreal, it is reported that butchers had to pay 50 livres per annum for the right to operate as a butcher. ${ }^{182}$ But this is not an important point given that I have very few observations for butchers and bakers and most of the observations (as we will see below) are related to river sailors, masons, sawyers and carpenters. The resulting dataset can be observed in Figure 3.2 (nominal and real wages of unskilled workers) and Figure 3.3 (nominal and real wages for carpenters). The deflator for real wages is the one constructed in the previous chapter. The details of the interpolation and checks for the data quality are available in Appendix 2. In that appendix, readers will find descriptions of the wage data and the interpolation required. For the vast remainder of the dissertation, I will rely on the daily wages only.

\footnotetext{
${ }^{181}$ Marc Vallières, Yvon Desloges, Fernand Harvey, Andrée Héroux, Réginald Auger, Sophie-Laurence Lamontagne and André Charbonneau. 2008. Histoire de Québec et de sa région, Tome 1 : Des origines à 1791. Québec : Presses de l'Université Laval, p.388-396.

182 Roland Viau. 2012. "Pour qui souffle le vent? Heur et malheur d'une entité coloniale, 1702-1760" in eds. Dany Fougères, Histoire de Montréal et de sa région, Tome 1, Des Origines à 1930. Québec : Presses de l'Université Laval, p. 207.
} 
Figure 3.2. Nominal and real wages (livres per day) of unskilled workers

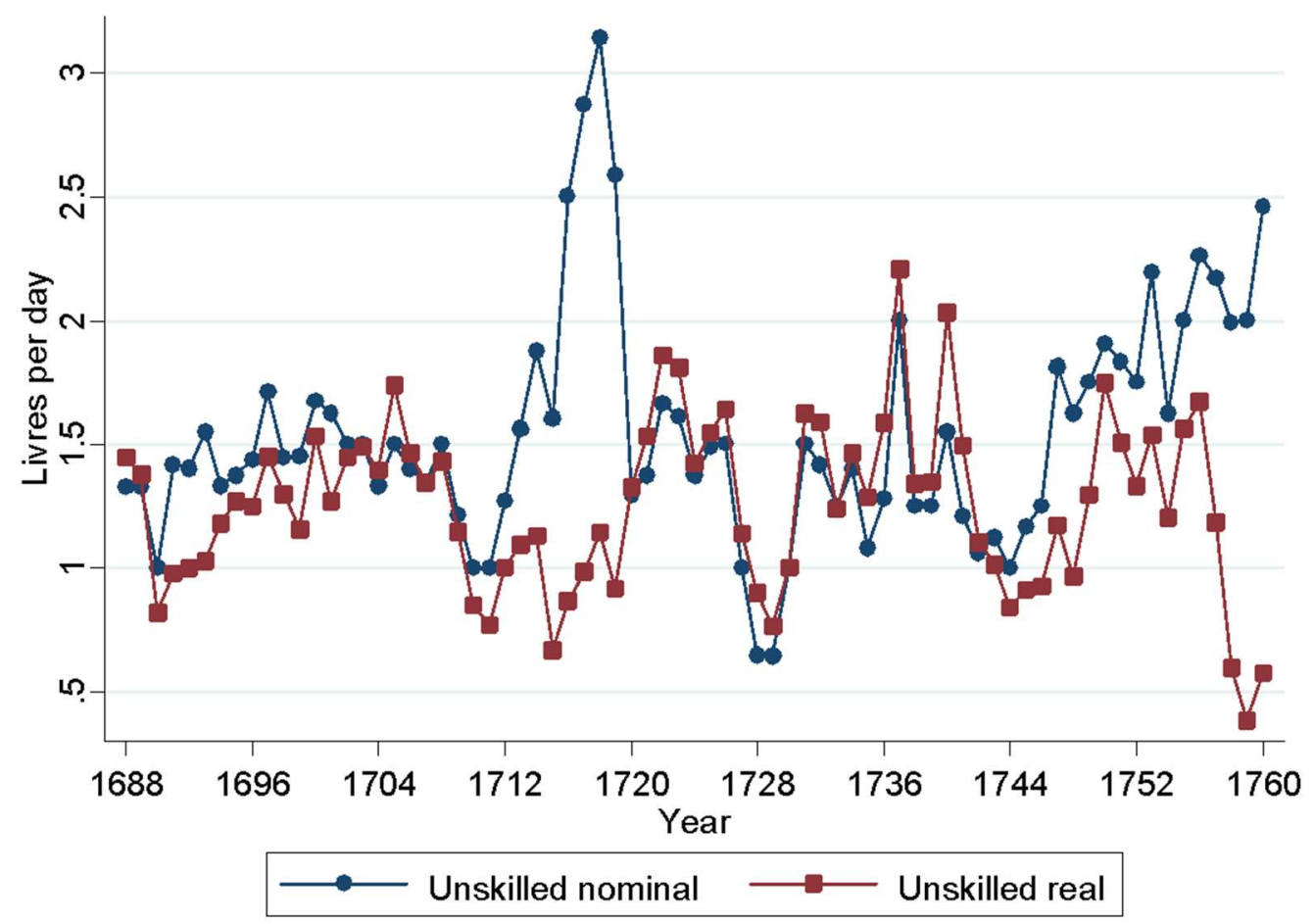

Figure 3.3. Nominal and real wages (livres per day) of carpenters

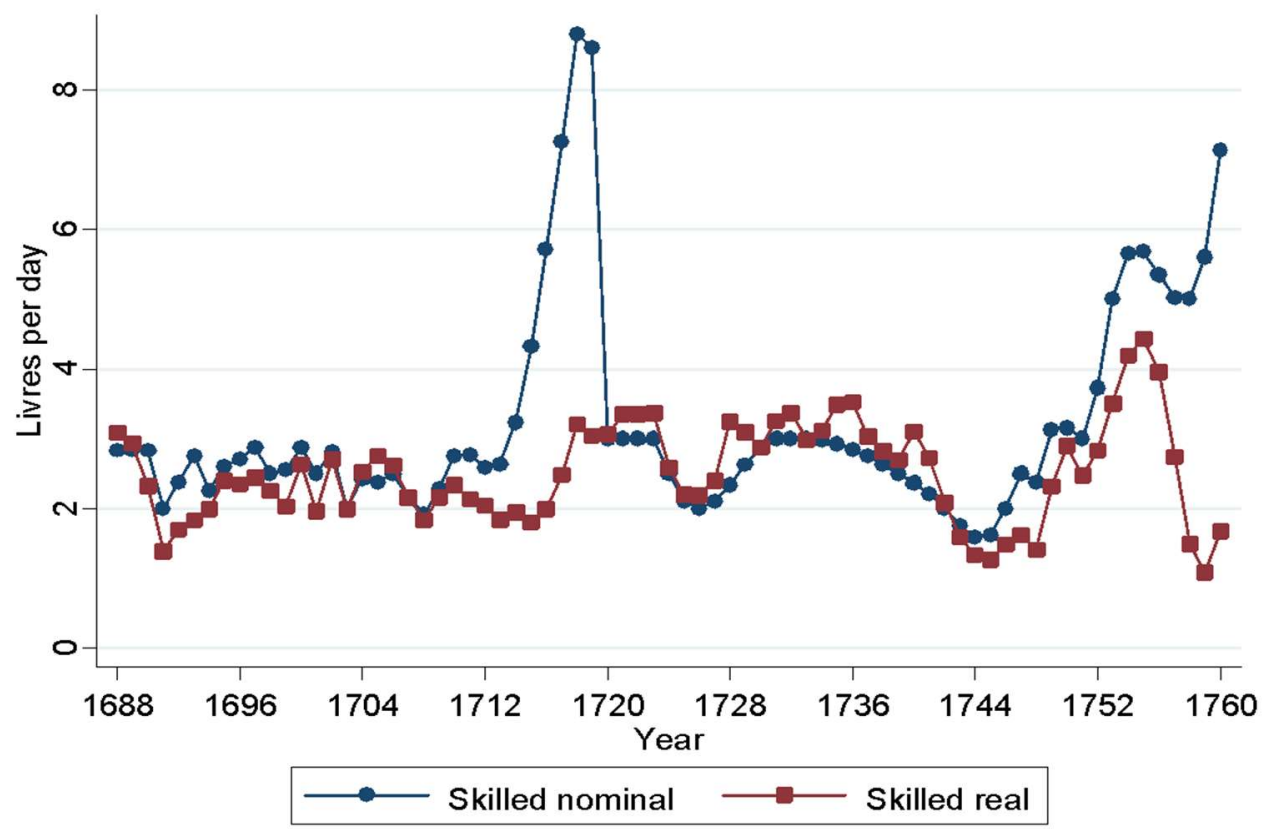




\subsection{Constructing the basket of goods for the welfare ratios}

Welfare ratios are constructed first by creating a basket of goods and services that households would need to achieve an objective standard of living. The computational exercise of welfare ratios requires a lengthy discussion on what the basket of goods ought to be. ${ }^{183}$ There are two definitions of a basket that we ought to consider. The first is meant to include the impact of the introduction of new goods that came with the colonization of the Americas and is meant as a basket of goods that represents a "respectable standard of living." Basically, this means a basket that would reflect consumption of more than the mere satisfaction of basic needs. ${ }^{184}$ The second basket is one which aims to measure how well one could satisfy his basic needs. In his works, Robert Allen cites that the English "respectability basket" provided roughly 2500 calories per person and 112 grams of protein per person. ${ }^{185}$ As for the subsistence basket (labelled as "bare bones"), he considers that it yielded 1938 calories and 89 grams of protein. ${ }^{186}$

In the case of New France, it is quite likely that the respectability threshold was close to what could be achieved by households. According to Richard Harris, each person required 6 minots of wheat per year (one minot $=1.107$ bushels). ${ }^{187}$ This translates into 1593 calories per day per person. ${ }^{188}$ This is obviously not a sufficient diet for people living in an agricultural economy like the one in New France and it could not have been the sole item in their diets. Thanks to the work of Donald Fyson, we are aware that grains represented $56 \%$ of all the calories consumed by workers in the early nineteenth century. ${ }^{189}$ We can infer that the 1593 calories per day represented only $56 \%$ of the energy intake of workers which means that adding the remaining $44 \%$ translates

\footnotetext{
${ }^{183}$ Readers should be aware that I expected to find a high standard of living in Quebec relative to other societies at the time. This is because most authors that have written about the living standards of French Canadians have tended to described them as such. Although examples are numerous, the best example supporting this expectation is that of Richard Harris who asserted "there can be little doubt that his [the French Canadian's] standard of living was substantially higher than that of most of the peasants in France, or that it compared favorably with living standards in rural New England" (Richard Harris. 1966 [1984]. The Seigneurial System in Early Canada. Montréal: McGillQueen's University, p.166.)

${ }^{184}$ Robert C.Allen. 2001. "The great divergence in European wages and prices from the Middle Ages to the First World War" Explorations in economic history, Vol.38, No.4, pp.420.

${ }^{185}$ Robert C. Allen. 2009. The British Industrial Revolution in Global Perspective. Cambridge: Cambridge University, p.36.

${ }_{186}$ Ibid, p. 37 .

${ }^{187}$ Richard Harris. 1966 [1984]. The Seigneurial System in Early Canada. Montréal : McGill-Queen's University, p.160.

${ }^{188}$ Christian Dessureault. 2005. "L'évolution de la productivité agricole dans la plaine de Montréal, 1852-1871 : grandes et petites exploitations dans un système familial d'agriculture." Social History/Histoire Sociale, vol.38, no.76, p.265.

${ }_{189}$ Donald Fyson. 1992. "Du pain au madère : L'alimentation à Montréal au début du XIXe siècle", Revue d'histoire de l'Amérique française, vol.46, no.1, p.74.
} 
into a total intake of 2845 calories per day. ${ }^{190}$ This amount of calories is roughly comparable to the totals proposed by other sources on Quebec history (see Table 3.2).

Table 3.2. Calories in food components

\begin{tabular}{cl} 
Source & Calories / day \\
\hline Geloso & 2845 calories / day \\
Rousseau (1704-1713) & 2632 calories / day \\
Rousseau (1714-1723) & 2628 calories / day \\
Rousseau (1724-1733) & 3504 calories / day \\
Lachance (mid-eighteenth century soldiers in New & 2958 calories / day \\
France) & \\
\hline
\end{tabular}

François Rousseau. 1983. L'œuvre de Chère en Nouvelle-France : Le régime des malades à l'hôtel-Dieu de Québec. Québec Presses de l'Université Laval, p.340; André Lachance. 2000. Vivre, Aimer et Mourir en Nouvelle-France: La Vie Quotidienne au XVIIe et XVIIIe siècles. Montréal: Éditions Libre Expression, p.148.

It is generally accepted that wheat represented close to three quarters of all grain output in the colony of New France. ${ }^{191}$ Again, according to the data collected by Donald Fyson, meat and alcohol represented respectively $21 \%$ and $10 \%$ of calorie intake (597 calories and 284 calories). ${ }^{192}$ Fyson also mentions that sugar and dairy products represented $8 \%$ and $6 \%$ of calories. Finally, the work of Allan Greer provides us with an estimate of 30 pounds of salt per adult per year-13,608 grams per year. ${ }^{193}$

With regard to the non-food components, one of the larger items in terms of expenditures for households was firewood. Quebec is an especially cold area of North America which means that fuel was likely to have commanded a larger share of a household's expenditures than would have been the case elsewhere in the world. In the eighteenth century, it was estimated that a priest required 25 cords of wood per year. ${ }^{194}$ In the late seventeenth century, it was estimated that a widow required 20 cords of firewood without any specification of the period for which they were required. ${ }^{195}$ As for lighting and heating, it is hard to know the per capita level of candle consumption. The best starting point with regard to constituting a basket is in the work of Allan

\footnotetext{
${ }^{190}$ Agricultural work, as pointed out by Craig Muldrew, tended to require much larger quantities of calories. However, these calories were disproportionately expended during the harvest. In New France, activity dropped importsignificantly in winter-winters which were considerably longer than those experienced in Europe. See: Craig Muldrew.2011. Food, Energy and the Creation of Industriousness: Work and Material Culture in Agrarian England, 1550-1780. Cambridge: Cambridge University Press, p.131

${ }^{191}$ Morris Altman. 1983. "Seigniorial Tenure in New France, 1688-1739: An Essay on Income Distribution and Retarded Economic Development". Historical Reflections / Réflexions historiques, Vol.10, No.3, pp.335-375.

192 Donald Fyson. 1992. "Du pain au madère : L'alimentation à Montréal au début du XIXe siècle", Revue d'histoire de l'Amérique française, vol.46, no.1, p.74.

193 Allan Greer. 1985. Peasant, Lord and Merchant: Rural Society in Three Quebec Parishes, 1740-1840. Toronto : University of Toronto Press, p.35.

${ }^{194}$ Marcel Mousette. 1983. Le chauffage domestique au Canada : des origines à l'industrialisation. Québec : Presses de l’Université Laval, p. 35

${ }^{195}$ Ibid, p.37.
} 
Greer. ${ }^{196}$ In his work, Greer manages to provide us with a basket of consumption for a peasant family in the plains of Montreal. As a young man, Joseph Blanchard and his wife (unnamed) promised a pension to his father (also named Joseph) and mother who had given him their lands. The son was to provide $5 \mathrm{~kg}$ of Candles or 3 pots of burning oil for his parents. At this ratio, this meant that 0.6 pots of burning oil were considered equivalent to $1 \mathrm{Kg}$ of candles. Finally, with regard to cloth, there is little data about the French era, but we know that in 1827, Lower Canadian families produced, on average, 8.3 yards of cloth per person - a figure that we will apply here and which will be transferred from the French measure of aune (see Appendix 1 for the metrological differences). ${ }^{197}$

Taken altogether, this suggests that New France probably could acquire many times the bare bones basket. Yet, one should be careful not to go too far. Most of the data mentioned above stems from work drawn either from probate records, religious congregations or from travellers recounting their tales. The former type of source is apparently concentrated in the upper echelons of society. This is because those who signed probate records in Quebec tended to be richer individuals, or at the very least were individuals that were more educated. They also tended to concern older individuals which implies a selection bias. Individuals who got around to writing a testament were individuals who had managed to live past a point that many did not manage to reach. Hence, the poorer levels of the New France society were not well represented. ${ }^{198}$ Secondly, religious congregations like that of the Augustines studied by Rousseau offer very rich consumption diets. But these are very likely non-representative of overall trends and levels. The calorie consumptions reported by Rousseau, which are very high and reported in Table 12, were for patients of the hospital — one fifth of whom were women, who would have required fewer than the more than 2500 calories per day reported by Rousseau. ${ }^{199}$ And these were calories for workers who were ill and needed to recover from different types of illness and injuries - some of which were of a military nature. Indeed, one third of all male admissions at the end of the seventeenth century were officers, sub-officers, soldiers and sailors. In other years, such as those between 1747 and 1751 , more than half (54.3\%) of the 3242 admissions were for soldiers and officers. ${ }^{200}$ Finally,

\footnotetext{
${ }^{196}$ Allan Greer. 2000. Habitants, Marchands et Seigneurs : la Société Rurale du Bas Richelieu, 1740-1840. Montréal : Éditions Septentrion, p.54-55.

${ }^{197}$ David Thiery Ruddel. 1990. "Domestic Textile Production in Colonial Quebec, 1608-1840", Material Culture Review / Revue de la culture matérielle, Vol.31, No.1, p.42.

${ }^{198}$ Peter Russell summarizes this point nicely when he surveys a debate between Jean-Pierre Wallot and Gilles Paquet on the one hand with Yves Morin on the other hand. In the early 1980s, Wallot and Paquet produced a breathtaking sample of probate records for Lower Canada (as it was known when under British rule) from 1792 to 1835 which showed positive wealth growth rates throughout the period studied. Morin questioned the validity of those statistics indicating that they represented mostly upper class, richer and literate individuals. See Peter Russell. 2012. How Agriculture Made Canada: Farming in the Nineteenth Century. Montreal and Kingston: McGill-Queen's University Press, p.61-62.

${ }^{199}$ François Rousseau. 1983. L'œeuvre de Chère en Nouvelle-France: Le régime des malades à l'hôtel-Dieu de Québec. Québec Presses de l'Université Laval, p.40-41.

${ }^{200}$ Ibid, p.42-44.
} 
contemporary observers like the often quoted Pehr Kalm (a Swedish botanist who visited the colony in the 1740s) actually spent very little time with the common inhabitants. Numerous authors have quoted $\mathrm{Kalm}^{201}$ who often described the richness of the diets of the inhabitants like his assertion "French-Canadian meals, if I may say so, are usually overabundant; they are served numerous dishes: soups as well as a variety of meat (...)" 202 That latter quotation did not refer to the French-Canadians per se but rather to members of the French-Canadian clergy-hardly a representative group. Although there is much to keep from his observations, one should be careful. Much of this skepticism stems from reading the work of Serge Lambert that studied institutions aimed at helping the poor in New France. His work, concentrated on urban centers, suggests very low living standards which are fairly generalized in the form of high vulnerability to small economic shocks. ${ }^{203}$ All things considered, it is likely that the French-Canadians enjoyed a level of living standards above the bare bones basket but there is reason to doubt the height of that advantage. $^{204}$

At this point, I must derive a basket of consumption. Testing only one basket might be problematic however. Consequently, I will attempt numerous different specifications. What will be designated below as "bare bones basket 1a" and "respectable basket $1 \mathrm{a}$ " will be the ones used for comparisons with other societies in the Americas and Europe. However, the other baskets are created in order to test the robustness of the results to different specifications changes. The hope is that by testing with alternative specifications, I will be able to assert the robustness of the estimates provided in this paper. As we will see, these alternative specifications do not change the general behavior or alter significantly the level of the cost of the baskets. Here are the baskets that I will generate:

1) Bare bones basket 1a: a basket which relies on oats and where firewood will be represented by white oak

\footnotetext{
${ }^{201}$ Richard Harris. 1966 [1984]. The Seigneurial System in Early Canada. Montréal: McGill-Queen's University, p.165.

${ }^{202}$ Quoted in in Paul-Louis Martin. 2002. Les Fruits du Québec : histoire et traditions des douceurs de la table. Montréal : Éditions Septentrion, p.49.

${ }^{203}$ Serge Lambert. 2001. Entre la crainte et la compassion : les pauvres à Québec au temps de la Nouvelle-France. Sainte-Foy, Les Éditions GID.

${ }^{204}$ Volume 1 of the Histoire de Québec et de sa région provides a long discussion on the issue of popular gastronomy in the colony. The authors illustrate that there is a great demand, illustrated from import data, for olive oil, olives, rum, coffee, and chocolate. Although it is possible that some of these were enjoyed mainly by the richest, but olive oil is indeed commonly reported as a "popular item" found in rural households. Proteins also seem to be consumed in large quantities via eels, codfish, beef and lard. Animal bones found in archaeological dig sites also suggest a large consumption of meat items. Overall, this is suggestive of the applicability of the "respectability basket". Marc Vallières, Yvon Desloges, Fernand Harvey, Andrée Héroux, Réginald Auger, Sophie-Laurence Lamontagne and André Charbonneau. 2008. Histoire de Québec et de sa région, Tome 1: Des origines à 1791. Québec: Presses de l’Université Laval, p.503-536.
} 
2) Bare bones basket $1 \mathrm{~b}$ : a basket which relies on oats and where firewood will be represented by Canadian pine

3) Bare bones basket 2a: a basket which relies on wheat and where firewood will be represented by white oak

4) Bare bones basket $2 \mathrm{~b}$ : a basket which relies on wheat and where firewood will be represented by Canadian pine

5) Respectable basket 1a: a basket of respectable consumption where firewood will be represented by white oak

6) Respectable basket 1b: a basket of respectable consumption where firewood will be represented by Canadian pine

In his work, Robert Allen creates a basket where maize was the dominant grain for the bare bones subsistence basket of goods, providing 1655 calories. The other items are straightforward and may very well apply to Quebec in the seventeenth and eighteenth centuries. However, maize is a not a good item to use for New France. According to census data, it did not appear as a common farm product until the nineteenth century. One could fall back on oats as a reliable source of calories. I am aware that French-Canadians rarely ate oats themselves, reserving them instead for their animals, and preferred wheat in general. ${ }^{205}$ However, in dire times, Yvon Desloges asserted that "while barley and oats could substitute for wheat during shortages, Quebeckers definitely preferred oats" even if in good times it served as fodder. ${ }^{206}$ Oats were indubitably the cheapest form of calories and it should be the bare bones crop. We know that one minot of oats provided only $62 \%$ of the calories of a minot of wheat. ${ }^{207}$ This lower caloric output was more than compensated by the differential in yields per unit of land. According to Marvin McInnis, who used mid-nineteenth century data, one acre could yield either 9.2 bushels of wheat or 18.6 bushels of oats. ${ }^{208}$ This means that one acre of land under oats yielded $26 \%$ more calories than wheat. This suggests that oats were the cheapest way to obtain calories. However, if the French-Canadians desired the cheapest source of calories, why do we find that oats were such a small share of total crops until the mid-nineteenth century? As Table 3.3 below documents, oats were generally an inconsequential crop representing at best one fifth of all calories produced. The emergence of oats as an important crop in Quebec occurred in the mid-nineteenth century and throughout the history of Quebec, it was mostly aimed at complementing the diet of animals and never as a diet item for

\footnotetext{
${ }^{205}$ Morris Altman. 1988. "Economic Growth, Economic Structure and Real Gross Domestic Product in Early Canada, 1695-1739" William and Mary Quarterly, Vol.45, p.698.

${ }^{206}$ Yvon Desloges. 1991. A Tenant's Town: Quebec in the $18^{\text {th }}$ century. Ottawa: Parks Canada, p.143.

${ }^{207}$ Christian Dessureault. 2005. "L'évolution de la productivité agricole dans la plaine de Montréal, 1852-1871 : grandes et petites exploitations dans un système familial d'agriculture.” Social History/Histoire Sociale, vol.38, no.76, p.265.

${ }^{208}$ Marvin McInnis. 1981. "Some Pitfalls in the 1851-1852 Census of Agriculture of Lower Canada", Social History / Histoire Sociale, vol.14, no.27, p. 227.
} 
the general population (except in dire times). ${ }^{209}$ Thanks to the adaptation of Scandinavian varieties of wheat being introduced in the colony, wheat was the main cereal in the diet of FrenchCanadians. ${ }^{210}$ In terms of accurately depicting the living standards of the colonists, a basket based on wheat would be best. Yet, in order to compare with France or England or the American colonists, this is not the best option. While wheat was the main item of consumption in Canada, it was not the cheapest source of calories nor was it the case that it was the most common type of cereal elsewhere. In his work on France's economic history, Jean-Marc Moriceau pointed out that in sixteenth century France, roughly a third of the crop came from oats. Moreover, thanks to the easier weather of the country, oats were more popular and accounted for a substantial share of the spring harvest. ${ }^{211}$ In France, it was a more common diet item. As a result, a basket relying on wheat would accurately depict the situation in New France. However, in a comparison with France, it would overstate the differences between the two. Consequently, I felt compelled to construct two "bare bones" basket based respectively on oats and on wheat (bare bones basket 1 and 2) to see if the trend changes. For the regional comparisons, I will rely only on the basket that uses oatswhich is more representative.

Table 3.3. Weights for arable sector by crop

\begin{tabular}{ccccccccc} 
Area, Year & Wheat & Peas & Barley & Oats & Potatoes & Corn & Hay & Others \\
\hline $\begin{array}{c}\text { Colony, 1700s } \\
\text { under French } \\
\text { rule }\end{array}$ & $75 \%$ & - & - & - & - & - & - & $25 \%$ \\
$\begin{array}{c}\text { Trois-Rivières, } \\
\quad 762 \text { a }\end{array}$ & $74.45 \%$ & $4.75 \%$ & $2.56 \%$ & $18.24 \%$ & - & - & - & - \\
$\begin{array}{c}\text { Montreal 1792- } \\
\quad 7796 \mathrm{~b}\end{array}$ & $70.6 \%$ & $6.9 \%$ & $1.1 \%$ & $10.6 \%$ & $0.4 \%$ & $0.1 \%$ & $7.7 \%$ & $2.6 \%$ \\
$\begin{array}{c}\text { Montreal 1807- } \\
1812 \mathrm{~b}\end{array}$ & $59.8 \%$ & $12 \%$ & $0.9 \%$ & $11.4 \%$ & $2.4 \%$ & $0.4 \%$ & $9.7 \%$ & $2.4 \%$ \\
\hline
\end{tabular}

Source: Morris Altman. 1983. "Seigniorial Tenure in New France, 1688-1739: An Essay on Income Distribution and Retarded Economic Development”. Historical Reflections / Réflexions historiques, Vol.10, No.3, pp.335-375; British Library. Add. Mss. 21681-2. Haldimand Collection: Papers relating to the government of Three Rivers in Canada, and to the ironworks in that district: principally during Haldimand's command; 1760-1767 . Reel No.10; Lorraine Gadoury. 1983. "Les stocks des habitants dans les inventaires après décès" Material Culture Review / Revue de la culture matérielle, Vol.17, Spring, pp. 127-138. NOTE: $a=$ In share of calories, $b=$ In share of revenues estimated in probate records.

A second important problem is the issue of fuel consumed. Baskets of goods conceived to allow the construction of welfare ratios are generally centered on a common standard of wellbeing - the energy derived in terms of BTUs. In his work, Robert Allen and his co-authors attribute

\footnotetext{
${ }^{209}$ Robert Lavertue. 1984. 'L’histoire de l'agriculture Québécoise au XIXe siècle : une schématisation des faits et des interprétations", Cahiers de géographie du Québec, Vol.28, no.73-74, pp.280-281.

${ }^{210}$ Gilles Deschênes. 2009. Quand le vent faisait tourner les moulins: Trois siècles de meunerie banale et marchande au Québec. Québec : Éditions du Septentrion, p.40-41.

211 Jean-Marc Moriceau. 1994. Les fermiers de l'Île-de-France : XVe-XVIIIe siècle. Paris: Fayard, p.875.
} 
a value of 2 million BTU per person per year in North America. ${ }^{212}$ This means less than one cord of firewood per person. This is very far from all the estimates found in the literature that place consumption somewhere between 20 and 25 cords for households which were typically composed of six individuals. And one cord of firewood alone provided more than the annual quantity required (5.55 MBTU per cord of pine and 9.075 MBTU per cord of white oak-see more below). This means that 3.33 cords (in French measure) were consumed per person at the very least-much more than what Allen et al. attribute (see Table 3.4 for calculations). This adjustment is crucial in attempts to compare New France and France, and also to compare New England with societies other than New France. Given the geographic and climatic similarities between New England and New France, it is not surprising to find that the American colonists consumed firewood in similar quantities as the inhabitants of the French colonies to the north. Indeed, Robert Gordon identified colonial households in Boston as requiring 30 cords of firewood per year in terms of consumption. ${ }^{213}$ Thomas Purvis echoes this measurement adding that "about $80 \%$ of all warmth generated was wasted" due to open air chimneys. ${ }^{214}$ Even by the mid-nineteenth century when fireplaces became more efficient, the consumption in New England remained high at between 10 and 20 cords of firewood. ${ }^{215}$ In his own work, Arthur Cole also confirms a high consumption of firewood similar to that of New France pointing out that students at Harvard and Princeton in the early nineteenth century were allotted 3 cords of firewood each. ${ }^{216}$ A second issue is that Canada is filled with different types of firewood. According to the history of the timber trade in Canada from 1763 to 1867 written by Arthur Lower, the colony of Quebec was filled with both oak and pine $^{217}$ - two trees whose combustion yields different quantities of energy (24.2 million BTU per cord and 14.8 million BTU respectively per cord of 128 cubic feet). ${ }^{218}$ Consequently, the cost of the basket will depend greatly on the type of firewood selected. This is why each basket has a

\footnotetext{
${ }^{212}$ Robert Allen, Tommy Murphy and Eric Schneider. 2012. "The Colonial Origins of the Divergence in the Americas: A Labor Market Approach", Journal of Economic History, Vol. 72, No. 4, pp.863-94.

${ }^{213}$ Robert Gordon. 2005. "Technology in Colonial North America" in A Companion to American Technology eds. Carroll Pursell, Malden, MA: Blackwell Publishing, p.25.

214 Thomas L. Purvis. 1999. Almanacs of American Life: Colonial America to 1763. New York, NY: Facts on File, p.10.

${ }^{215}$ Gordon Whitney. 1996. From Coastal Wilderness to Fruited Plain: A History of Environmental Change in Temperate North America from 1500 to the Present. Cambridge: Cambridge University Press, p.210.

${ }^{216}$ Arthur H. Cole. 1970. "The Mystery of Fuel Wood Marketing in the United States", Business History Review, Vol.44, No.3, p.340.

${ }^{217}$ Arthur R.M. Lower. 1973. Great Britain's Woodyard: British America and the Timber Trade, 1763 to 1867. Montreal and Kingston: McGill-Queen's University Press.

${ }^{218}$ This is for a cord which stands at four feet high, four feet deep and eight feet long (128 cubic feet). According to Gilles Paquet and Jean-Pierre Wallot (1998. "Some Price Indexes for Quebec and Montréal (1760-1913)", Histoire Sociale / Social History, vol.31, no.62, p.311), the common cord of firewood in Quebec was of dimensions of six feet high, four feet deep and two feet long (48 cubic feet). This means that the Quebec cord of firewood was only 37.5\% that of the one for this measurement. This paper has adjusted the values appropriately. To make the adjustments, I computed the price of firewood per cubic foot, and then I adjusted this measurement to make it so that the cord has a volume of 128 cubic feet and then divided by the BTUs for each type of firewood. The amount of MBTU per type of wood was derived thanks to the computations made available on the website of https://chimneysweeponline.com/howood.htm (consulted November 4th 2014).
} 
variant in terms of the type of firewood used. I have also increased the per person consumption of firewood to 20 million BTU. Below this line, it is hard to see how an individual could have survived winter. This is closer to the estimates provided by the literature, but it is markedly lower to reflect a certain level of scarcity. In the respectable basket, I increased that quantity to $30 \mathrm{MBTU}$. Table 3.5 illustrates the different bare bones baskets while Table 3.6 illustrates the Allen respectability basket in comparison with ours. Figures 3.4 and 3.5 illustrate the resulting baskets.

Table 3.4. MBTU produced for fuel consumption reported in literature

Cubic feet consumed

(each French cord was 48 cubic feet)
MBTU provided by

French measure if Canadian pine
MBTU provided by

French measure if white

\begin{tabular}{cccc} 
& cubic feet) & Canadian pine & oak \\
\hline $\begin{array}{c}3.33 \text { cords per year per } \\
\text { person (20 cords divided } \\
\text { by six household members) }\end{array}$ & 159.84 & $18.482 \mathrm{MBTU}$ & $30.219 \mathrm{MBTU}$ \\
$\begin{array}{c}\text { 4.17 cords per year (25 } \\
\text { cords divided by six } \\
\text { household members) }\end{array}$ & 200.16 & $23.145 \mathrm{MBTU}$ & $37.842 \mathrm{MBTU}$ \\
\hline
\end{tabular}

Note: The estimates of energy provided by different types of wood I used allow for a degree of humidity in the wood which reduces the energy output. They also consider a less than perfect combustion where a sizable energy output it wasted by poor extraction capacity. The source I used computes that only $71 \%$ of total energy available when wood contains $0 \%$ moisture and is combusted in a pure oxygen environment is extracted. The amount of MBTU per type of wood was derived thanks to the computations made available on the website of https://chimneysweeponline.com/howood.htm (consulted November 4th 2014).

Table 3.5. Bare bones basket

Allen, Murphy and Bare bones basket 1a and Bare bones basket 2a and

\begin{tabular}{cccc} 
& $\begin{array}{c}\text { Allen, Murphy and } \\
\text { Schneider }\end{array}$ & $\begin{array}{c}\text { Bare bones basket la and } \\
1 \mathrm{~b}\end{array}$ & $\begin{array}{c}\text { Bare bones basket 2a and } \\
2 \mathrm{~b}\end{array}$ \\
\hline Maize & $165 \mathrm{Kg}$ & & \\
Oats & & $153.96 \mathrm{Kg}$ & $169.96 \mathrm{Kg}$ \\
Wheat & & & $20 \mathrm{Kg}$ \\
Peas & $20 \mathrm{Kg}$ & $20 \mathrm{Kg}$ & $5 \mathrm{Kg}$ \\
Meat & $5 \mathrm{Kg}$ & $3 \mathrm{Kg}$ & $3 \mathrm{Kg}$ \\
Butter & $3 \mathrm{Kg}$ & $3 \mathrm{Kg}$ & $1.3 \mathrm{Kg}$ \\
Soap & $1.3 \mathrm{Kg}$ & $1.3 \mathrm{Kg}$ & 3 meters \\
Cloth & 3 meters & 3 meters & $1.3 \mathrm{Kg}$ \\
Candles & $1.3 \mathrm{Kg}$ & $1.3 \mathrm{Kg}$ & 1.3 liters \\
Lamp oil & 1.3 liters & 1.3 liters & $20 \mathrm{MBTU}$ \\
Fuel & $2 \mathrm{MBTU}$ & $20 \mathrm{MBTU}$ & \\
\hline
\end{tabular}

Note: Some readers might find strange that wheat, a more expensive item per calorie yielded, is only a few kilograms more to provide the same 1655 calories proposed by Allen, Murphy and Schneider. The reason for this difference is that the physical weight of a minot of oats was 34 pounds while a minot of wheat weighed 60 pounds. But a minot of wheat yielded 96,728 calories and one of oats yielded 60,509 calories. These statistics are found in Christian Dessureault. 2005. "L'évolution de la productivité agricole dans la plaine de Montréal, 1852-1871 : grandes et petites exploitations dans un système familial d'agriculture." Social History/Histoire Sociale, vol.38, no.76, p.265. Readers should also remember that prices recorded in Chapter 3 of this thesis were reported as minots when it came to grains. We have their conversion into modern pounds. However, prices for butter, beef and other non-cereal products were given in livres (french pounds) which contained 489.5 grams (while the pounds for which we have the conversion thanks to Dessureault stand at 454 grams per pound). Great care went to making sure this problem was avoided. 
Table 3.6. Respectability baskets

\begin{tabular}{ccc} 
& Allen & Respectable Basket 1a and 1b \\
\hline Bread (wheat) & $234 \mathrm{~kg}$ & $201.35 \mathrm{~kg}$ \\
Beans (peas) & 521 & $39.45 \mathrm{~kg}$ \\
Meat (beef) & $26 \mathrm{~kg}$ & $26 \mathrm{~kg}$ \\
Butter & $5.2 \mathrm{~kg}$ & $10.4 \mathrm{~kg}$ \\
Cheese & $5.2 \mathrm{~kg}$ & \\
Eggs & $52 \mathrm{eggs}$ & $52 \mathrm{eggs}$ \\
Wine & & 68.251 \\
Beer & 1821 & \\
Soap & $2.6 \mathrm{~kg}$ & $2.6 \mathrm{~kg}$ \\
Linen & $5 \mathrm{~m}$ & $5 \mathrm{~m}$ \\
Candles & $2.6 \mathrm{~kg}$ & $2.6 \mathrm{~kg}$ \\
Lamp oil & 2.61 & 2.61 \\
Fuel & $5.0 \mathrm{MBTU}$ & $30 \mathrm{MBTU}$
\end{tabular}

Note: In his work, Robert Allen replaced beer by 68.25 liters of wine. Robert C. Allen. 2009. The British Industrial Revolution in Global Perspective. Cambridge: Cambridge University, p.36. Note 1: If households used only pine as firewood, the 3.33 cords per person would have provided 18.48 MBTU per person and if it was white oak, 30.22 MBTU would have been provided per person (and much more if the estimate of 4.17 cords is chosen). I chose 30 MBTU because it was roughly between these two possibilities. Note 3 : Using the Dessureault (Christian Dessureault. 2005. "L'évolution de la productivité agricole dans la plaine de Montréal, 1852-1871 : grandes et petites exploitations dans un système familial d'agriculture." Social History/Histoire Sociale, vol.38, no.76, p.265) statistics for calorie per type of grains in Canada, I obtained $161.34 \mathrm{~kg}$ if all the calories from wheat were captured. However, since François Rousseau reports that $24.8 \%$ of a minot was lost in processing from wheat to flour. Hence I boosted the $161.34 \mathrm{~kg}$ by $24.8 \%$ for the losses incurred in processing (François Rousseau. 1983. L'ouvre de Chère en Nouvelle-France : Le régime des malades à l'hôtel-Dieu de Québec. Québec Presses de l'Université Laval, p.395).

Figure 3.4. Bare bones basket 1a, 1b, 2a and $2 \mathrm{~b}$ in livres

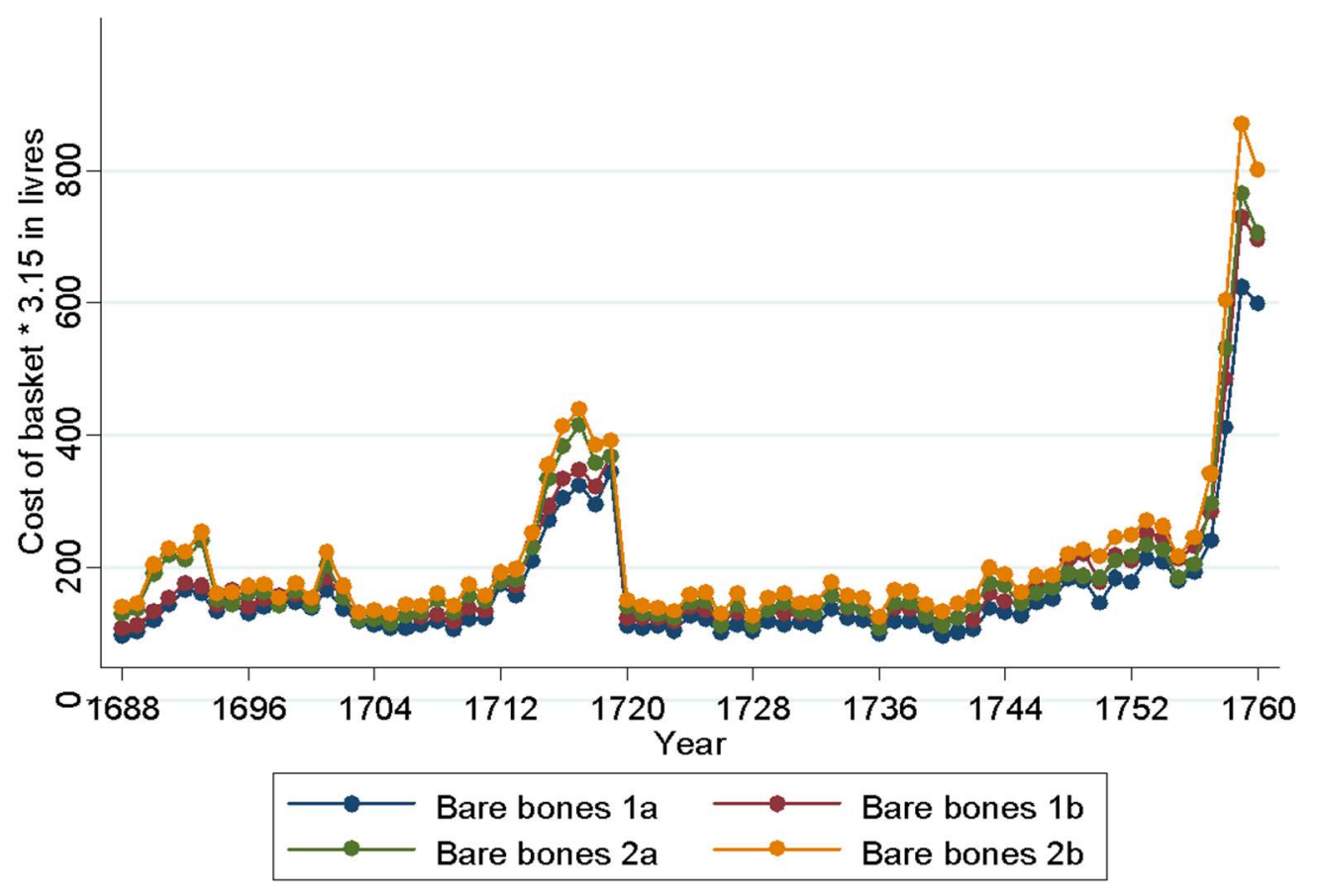


Figure 3.5. Respectable basket $1 \mathrm{a}$ and $1 \mathrm{~b}$ in livres

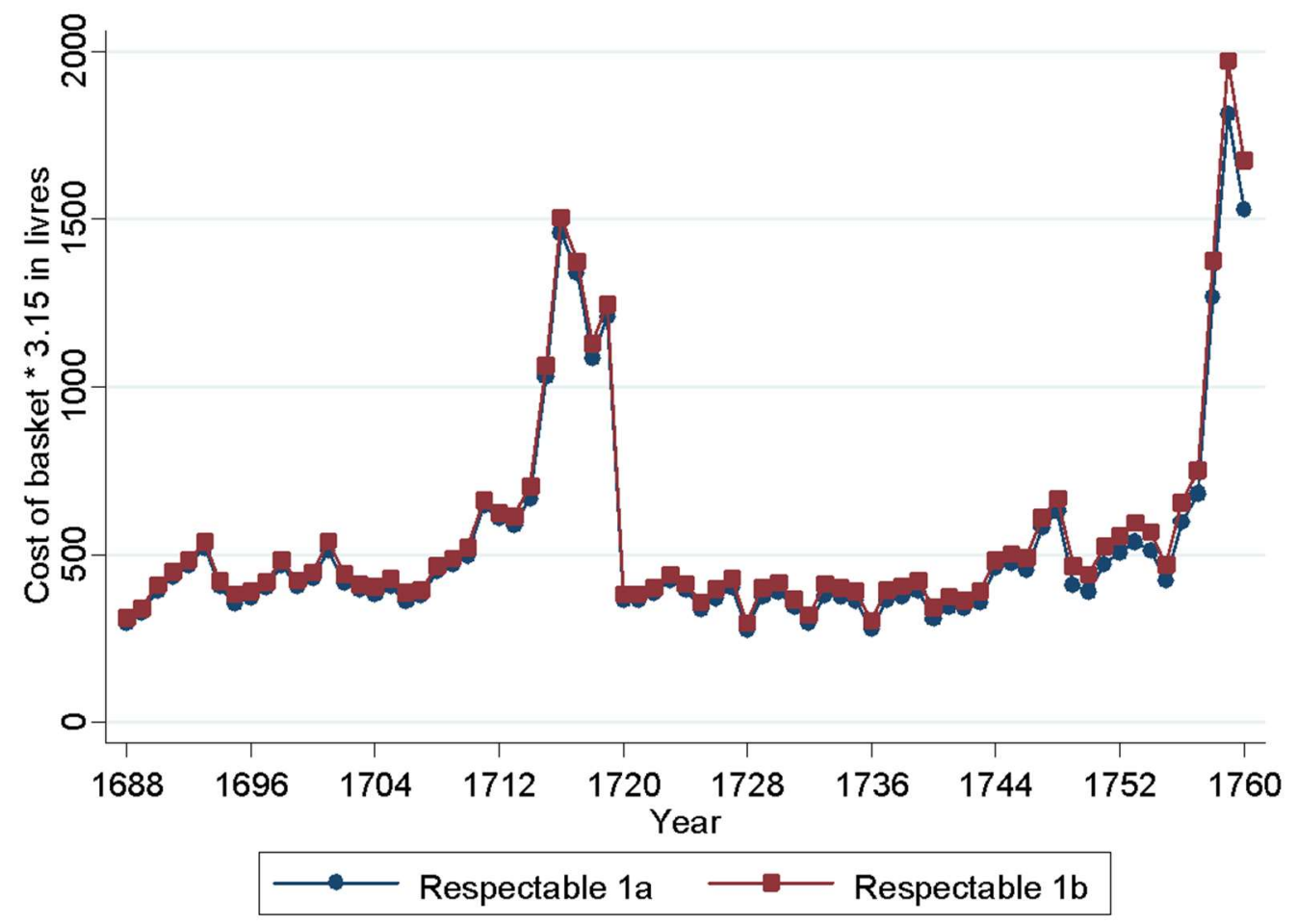

The baskets illustrated above are then multiplied by 3.15 to reflect the number of adult equivalents (i.e. economies of scale in the household in addition to different energetic requirement according to gender and age) an allowance for rent. This multiplication is the one commonly used in the literature. Although I have some reluctance about using that exact number, I felt that there was no point trying to contradict this particular convention here. However, the next chapter will detail how the results that will be seen below are presented in the most conservative fashion. It will be shown that relaxing some assumptions like the equivalence scales for family size and other minor points would widen the gap between New France and the other areas.

As one can see from Figures 3.4 and 3.5, the effect of using different types of firewood only has an effect on the level of the curve, but the effect is minimal. This is reassuring. As a result, I will now use the average of each type of basket with the different wood (baskets 1a and 1b will now be presented as basket 1). As for the effect of using oats or wheat in the bare bones basket, the trend is the same, but the level changes. As a result, the results will be presented as bare bones basket 1 and 2 in order to have "lower" and "upper" bounds. 


\subsection{Welfare ratios in New France over time}

Given the information discussed above, what does the economic evolution (performance) of New France look like? Some additional steps are needed before proceeding to the computation of the welfare ratios. Normally, some would tend to create figures of average wages by weighing the different observed wage rates by the occupational structure of the population. ${ }^{219}$ However, the detailed censuses of occupations in New France do not allow making inferences that would be reliable with regard to the occupational structure. Consequently, I am forced to concentrate on unskilled workers. But this is not a costly problem since the vast majority of the population was unskilled. Moreover, as pointed out above, there was a considerable scarcity of skilled workers in New France. Additionally, these are the wage rates used by Allen and his coauthors in their comparison of living standards in the Americas during the colonial era. ${ }^{220}$ However, I will also present welfare ratios for skilled workers such as carpenters. The first test is to measure how living standards evolved over time in the colony of New France. The first approach used to compute the welfare ratio is merely to multiply the wage rate by 250 days and then divide this by the cost of the two different baskets. Whenever the result of such a computation is above one, it means that at 250 days of work per year, the worker is able to acquire the full basket specified and has some income left to spend on other goods and services. Likewise, if the result is below one, the worker is unable at 250 days of work per year, to acquire such a basket. Obviously, the result depends largely on the assumption of the number of days worked. But this issue will only be addressed in the next part of my thesis in order to complete the picture. In the following Figures 3.6 and 3.7, we can see the welfare ratios for both unskilled and skilled workers.

\footnotetext{
219 Tomas Cvrcek. 2013. "Wages, Prices and Living Standards in the Habsburg Empire, 1827-1910", Journal of Economic History, Vol. 73, No.1, p.22.

${ }^{220}$ Robert C. Allen, Tommy E. Murphy and Eric B. Schneider. 2012. "The Colonial Origins of the Divergence in the Americas: A Labor Market Approach”, Journal of Economic History, Vol.72, No.4, pp.868.
} 
Figure 3.6. Welfare ratios at 250 days per year for unskilled workers

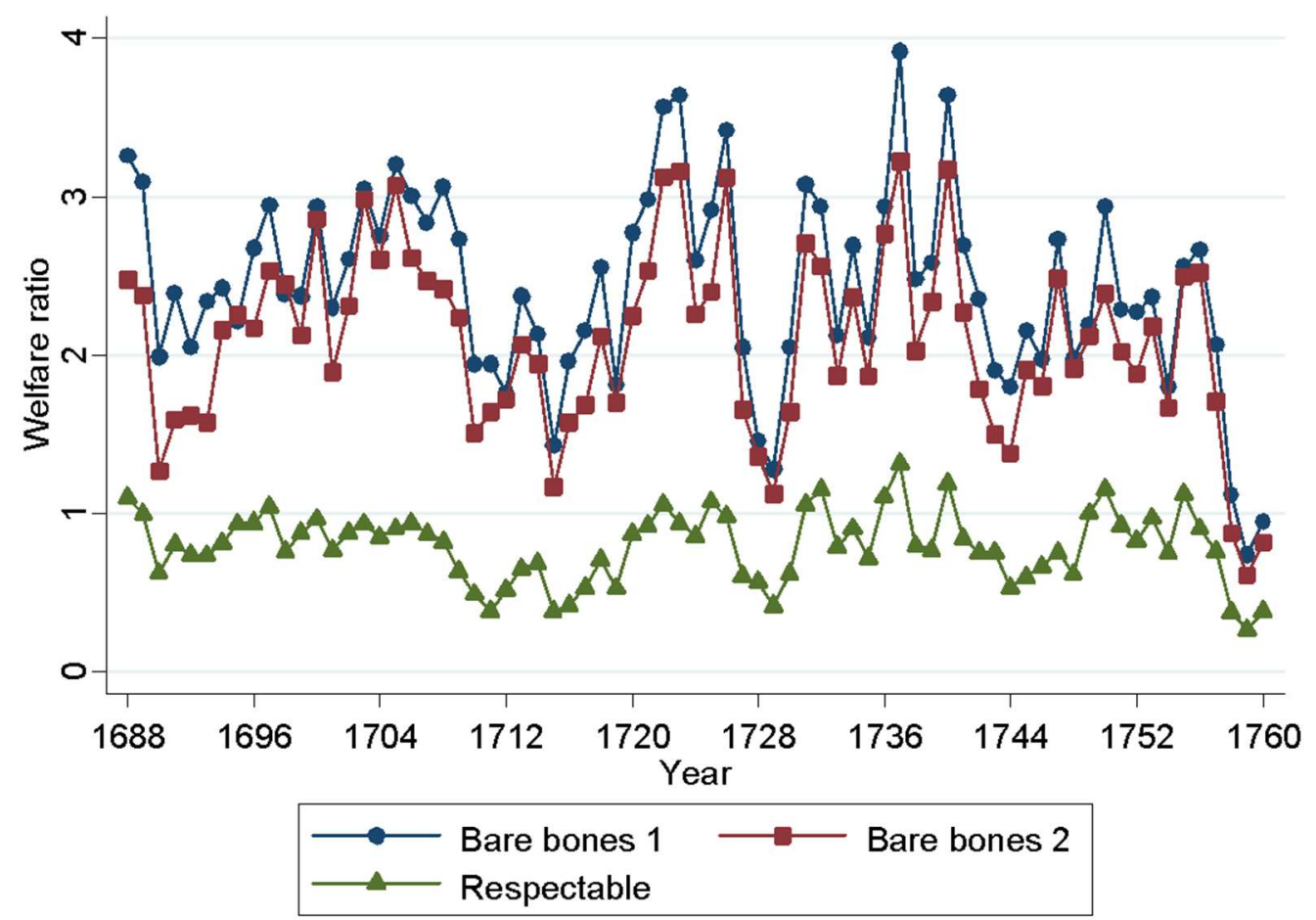

Figure 3.7. Welfare ratios at 250 days per year (carpenters)

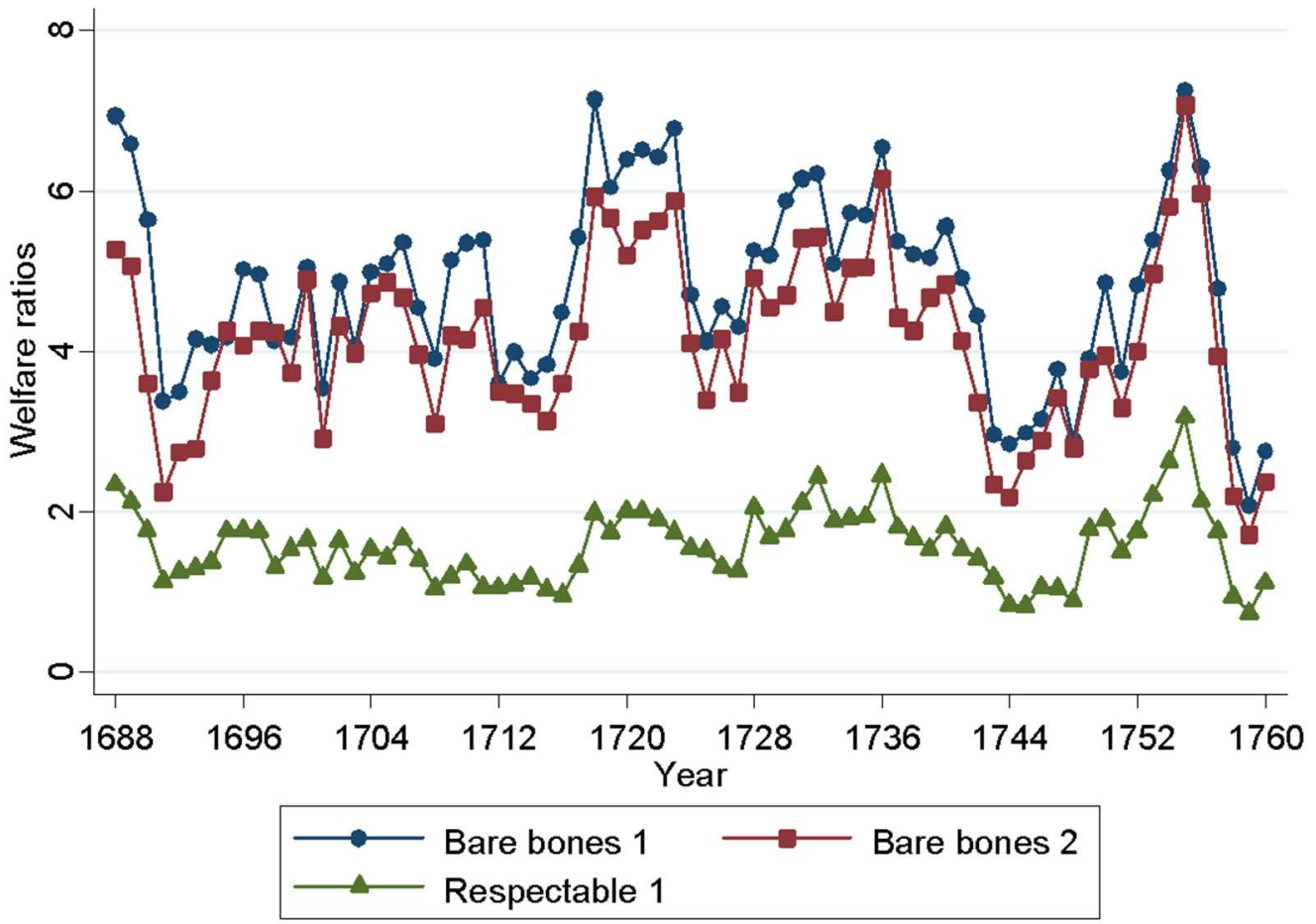


As one can see, the level observed with regard to the bare bones basket is generally high (above one except in two years over the period). However, the level with regard to the respectability basket is much lower and is generally below one. Both these measures of welfare exhibit no steady improvement throughout the period. On the other hand, Figure 3.7 shows that this stagnation was shared among the overall population. Skilled workers, approximated by carpenters' wages, had higher welfare ratios but they too failed to experience greater living standards. Moreover, living standards did not increase significantly-they remained at their plateau. However, there was a large collapse in the two wars that marked the two decades prior to the Conquest. Moreover, readers should observe that regardless of the basket assumption selected, the results are very similar. This reinforces the earlier claim that alternative specifications will not alter the results in any meaningful way. Hence, a first quantitative conclusion is finally available: there was no marked improvement in welfare ratios during the entirety of French rule. What movements there are are downwards and occurred in wartime and living standards recuperated shortly thereafter. This generates the first main takeaway regarding living standards. There were no substantial long-term improvements throughout the era of French rule. Living standards flatlined until the end.

\subsection{Welfare ratios comparison between France and New France}

Now that we know the evolution of living standards over time, the next step is to evaluate how New France fared in comparisons with other societies. Since New France was a French colony, the obvious starting point is France. The data with which to compare is easily available thanks to the work of Robert Allen who left detailed datasets for Paris and Strasbourg. ${ }^{221}$ Benchmarking the living standards of the inhabitants of New France against living standards in Paris is probably biasing the comparison against New France as Philip Hoffman has documented how the Paris basin was one of the most dynamic economic regions of France during the eighteenth century. ${ }^{222}$ The rest of France lingered behind Paris. Robert Allen put the welfare ratios of building laborers, using a basket between the bare bones and respectable baskets, at 0.8 in 1700-1749 (read: a laborer's work year could buy him $80 \%$ of the respectable basket of goods) well below the level enjoyed in London. ${ }^{223}$ Jacob Weisdorf and Paul Sharp also point to a similar conclusion with regard to the standing of France relative to Britain. ${ }^{224}$ The empirical comparisons will be divided two

\footnotetext{
221 The data is available online on the website of Robert Allen : http://www.nuffield.ox.ac.uk/People/sites/Allen/SiteAssets/Lists/Biography\%20Sections/EditForm/Labourers.xls.xl $\underline{\mathrm{S}}$

222 Philip Hoffman. 1996. Growth in a Traditional Society: The French Countryside, 1450-1815. Princeton, NJ: Princeton University Press.

${ }^{223}$ Robert C.Allen. 2001. "The great divergence in European wages and prices from the Middle Ages to the First World War" Explorations in economic history, Vol.38, No.4, pp.428.

${ }^{224}$ Paul Sharp and Jacob Weisdorf. 2012. "French revolution or industrial revolution? A note on the constrating experiences of England and France up to 1800", Cliometrica, Vol.6, No.1, pp.79-88.
} 
ways. The first will compare with Paris - one of the richest areas of France. ${ }^{225}$ The second will compare with other cities in France in order to obtain a clear picture of the differences. The other price series and wage series available for France come from Strasbourg - a landlocked city which contributed a negligible share of the total number of migrants to New France. The majority of migrants came from Saintonge (near La Rochelle), Poitou, Normandy and Paris. ${ }^{226}$ The former regions were considered to be fairly prosperous relative to Paris. ${ }^{227}$ Consequently, it is my belief that the Paris living standards are more representative of the living standards enjoyed by those who migrated to Canada - hence acting as a reasonable benchmark. However, the other areas will also be included to be safe. I have slightly modified the baskets for France so that they match identically the baskets I used for New France (see Tables 3.7 and 3.8). In addition, since I had no prices for bread in Canada and since I wanted to assure comparability, I decided to use wheat in the same quantity for the respectable basket.

Table 3.7: Comparison of bare bones basket for New France and France (1688 to 1760)

\begin{tabular}{lll} 
& $\begin{array}{l}\text { Bare bones basket } 1 \text { for New } \\
\text { France }\end{array}$ & Bare bones basket for France \\
\hline Oats & $153.96 \mathrm{Kg}$ & $153.96 \mathrm{Kg}$ \\
Wheat & - & - \\
Peas & $20 \mathrm{Kg}$ & $20 \mathrm{Kg}$ \\
Meat & $5 \mathrm{Kg}$ & $5 \mathrm{Kg}$ \\
Butter & $3 \mathrm{Kg}$ & $3 \mathrm{Kg}$ \\
Soap & $1.3 \mathrm{Kg}$ & $1.3 \mathrm{Kg}$ \\
Cloth & $3 \mathrm{~meters}$ & $3 \mathrm{~meters}$ \\
Candles & $1.3 \mathrm{Kg}$ & $1.3 \mathrm{Kg}$ \\
Lamp oil & 1.3 liters & 1.3 liters \\
Fuel & $20 \mathrm{MBTU}$ & $2 \mathrm{MBTU}$ \\
\hline
\end{tabular}

Note: In Allen's dataset, oats for Paris is missing observations for many years; however, Hoffman provides them in full and I opted to use Hoffman's price (anyhow, they are nearly identical) (Available online at the Global Price and Income History Group, Paris 1380-1870, http://gpih.ucdavis.edu/Datafilelist.htm). As for peas, there were also problems of missing data, and I opted for a similar method as for oats but the gaps in data were much greater. Hence, the periods from 1696 to 1701 and from 1703 to 1728 provided non-moving data points. Prices of oats were provided in liters which is not a measure of volume not of weight. Hence, to conform with the basket, I had to transform this volume into weight. The problem is that the conversion from volumes to weights is highly disputable. In 1921, Wesley C. Mitchell published his price index for the United States which contained numerous estimates for this conversion. For oats, the figures he proposed stand between from 386 grams per liter to 415 grams per liter. For wheat, the estimates stand between 715 and 755 grams per liter. (Wesley C. Mitchell. 1921. Index Numbers of Wholesale Prices in the United States and Foreign Countries. Washington D.C.: Bureau of Labor Statistics, p.248-249). In his work, Christian Dessureault points out that the minot (1.107 bushels) stood at 39.025 liters. One minot of oats weighed 34 pounds, one minot of wheat weighed 60.7 pounds and one minot of peas weighed 60 pounds. This meant 395.5 grams

\footnotetext{
225 Jean-Marc Moriceau. 1994. Les fermiers de l'Île-de-France : XVe-XVIIIe siècle. Paris: Fayard.

${ }^{226}$ Hubert Charbonneau and Normand Robert. 1991. "The French Origins of the Canadian Population, 1608-1760" in Concise Historical Atlas of Canada eds. William Dean, Conrad Heidenrich, Thomas Mcllwraith and John Warkentin, Toronto: University of Toronto Press, plate 34.

${ }^{227}$ B. Garnier 1986. "Problème de reproduction économique et sociale dans le bocage normand au XVIIIe siècle" in Évolution et Éclatement du Monde Rural, France-Québec XVII-XXè siècles eds. Joseph Goy and Jean-Pierre Wallot, Paris and Montréal : Presses de l'Université de Montréal and Éditions de l'École des Hautes Études en Sciences Sociales, p.121-140.
} 
of oats per liter, 706.16 grams per liter for wheat and 698.01 grams per liter of peas (Christian Dessureault. 2005. "L'évolution de la productivité agricole dans la plaine de Montréal, 1852-1871 : grandes et petites exploitations dans un système familial d'agriculture." Social History/Histoire Sociale, vol.38, no.76, p.265). I have opted to use the units as proposed by Dessureault. However, I should point out that future research should tackle the issue of proper measurement conversions as this murky field clouds the proper comparisons of living standards across space.

Table 3.8. Comparison of respectability basket for New France and France (1688 to 1760) Respectability Basket for France

Respectability basket for New

$\begin{array}{ccc}\text { Bread (wheat) } & 201.35 \mathrm{~kg} & 201.35 \mathrm{~kg} \\ \text { Beans (peas) } & 39.45 \mathrm{~kg} & 39.45 \mathrm{~kg} \\ \text { Meat (beef) } & 26 \mathrm{~kg} & 26 \mathrm{~kg} \\ \text { Butter } & 5.2 \mathrm{~kg} & 10.4 \mathrm{~kg} \\ \text { Cheese } & 5.2 \mathrm{~kg} & - \\ \text { Eggs } & 52 \mathrm{eggs} & 52 \mathrm{eggs} \\ \text { Wine } & 68.251 & 68.251 \\ \text { Soap } & 2.6 \mathrm{~kg} & 2.6 \mathrm{~kg} \\ \text { Linen (cloth) } & 5 \mathrm{~m} & 5 \mathrm{~m} \\ \text { Candles } & 2.6 \mathrm{~kg} & 2.6 \mathrm{~kg} \\ \text { Lamp oil } & 2.6 \mathrm{l} & 2.6 \mathrm{l} \\ \text { Fuel } & 5.0 \mathrm{MBTU} & 30 \mathrm{MBTU}\end{array}$

Note: see previous table

Before proceeding however, an important digression is needed regarding the dataset for Strasbourg which is the only long-term comparison available other than Paris. The Strasbourg wage rate proposed by Allen is constant between 1688 and 1760 at 2.88 grams of silver per day for an unskilled worker. This is incredibly low and unrepresentative of reality. Some doubts regarding the level of wages in Strasbourg have been raised by Nick Mayhew who believes them to be too low. ${ }^{228}$ The original source used by Allen to derive his data from Strasbourg comes from Charles Auguste Hanauer who published, in 1876, his study of Alsatian economic history titled Études économique sur l'Alsace ancienne et moderne. ${ }^{229}$ Hanauer was an abbé (a religious official) who was very active in the study of Alsatian history, notably as the director of archives at the library of Haguenau in the French part of the Lower Rhine. Hanauer left us with an autobiographical essay which looks more like a bibliographical essay justifying the need for his Études économique which he considered his magnum opus. ${ }^{230}$ In the essay, he points out how he was surprised by the wealth of information he managed to find to address the "utter darkness" he had found upon embarking on his twelve years project to draw a statistical portrait of Alsace. In view of the richness of the data, the assumptions made by Allen are hard to understand. In none of the series provided by Hanauer (which also divides wage rates according to whether or not daily workers were fed by the

\footnotetext{
${ }^{228}$ I would like to thank Judy Stephenson for this insight. After a presentation at the LSE's internal seminar, she pointed out this problem to me. After consulting the original sources and Mayhew's comments, I felt compelled to make the corrections. Nick Mayhew. Forthcoming. "Money in England from the middle ages to the nineteenth century" in Coins, Currency and Crisis, London: Routledge Press, pages undetermined.

${ }^{229}$ Charles Auguste Hanauer. 1878. Études économiques sur l'Alsace ancienne et moderne (denrées et salaires). Paris : Société industrielle de Mulhouse.

${ }^{230}$ Charles August Hanauer. 1908. Autobiographie. Colmar, A.M.P Ingold, p.19.
} 
employer) is there stability in wage rates. Consequently, this is an issue that must be addressed in order to properly compare Canada with the rest of France, hence the need to return to Hanauer's original work.

In his work, Hanauer provides wages for gâcheurs which Allen considers to be construction laborers. In his statistical files, Allen notes that he used the gâcheur wages for the summer period. The datapoint in Hanauer's work that fits with Allen's wage rate states merely "1702-1761 Mulh" with 0.64 francs per day at 4.5 grams per franc. ${ }^{231}$ The term "Mulh" refers to the city of Mulhouse - $114 \mathrm{~km}$ south of Strasbourg. No reasons are provided for the selection of Mulhouse as a stand-in for Strasbourg. In the same period, masons were paid 3.6 grams per day in winter. Yet, a few kilometers down the road in Colmar ( $73 \mathrm{~km}$ south of Strasbourg), we see that masons earned $20 \%$ more (4 grams of silver) between 1726-1744 and 50\% more (5.6 grams of silver) between 1746 and 1749. Although no information is provided for Colmar with regard to gâcheurs, it would be reasonable to expect higher levels as well given the geographical proximity. Yet, this geographical proximity is perplexing - why would such differences exist in a small confine of space? Yet, at the end of each chapter on wages, Hanauer divided wage rates by twenty-five year periods and presented regional averages. ${ }^{232}$ In the period that interests us, Hanauer suggests 3.375 grams of silver per day as the lowest figure - a 17.2\% gap (in the period from 1726 to 1750). In addition, Hanauer is not clear in his tables for construction workers whether the wages included food. However, his detailed observation for Mulhouse in 1702 says a worker was paid 0.72 franc (3.24 grams of silver) per day "plus le goûter" (plus food) up to $1706 .{ }^{233}$ Although the wage rate comes closest to Allen's suggestion-Hanauer's statement points to the fact that the differences resulted from payment in-kind. Although it is hard to confirm this suspicion directly from Hanauer's work, there is a roundabout way by looking at the definition of the gâcheur which was meant as a stand-in for unskilled workers. A French dictionary of construction published in 1881 provides answers which suggest that a gâcheur was a "maîtrise ouvrier charpentier"-meaning that he was a carpenter. ${ }^{234}$ Another dictionary suggests that it referred to those who supervised the work of carpenters. ${ }^{235}$ That same dictionary suggests that an aide (helper) was an ouvrier which makes that series better suited to capture unskilled workers. ${ }^{236}$ Yet, the wage rates for the ouvriers are actually higher than those for the gâcheur (4.5 grams of silver per day as the lowest point). It is hard to believe that a skilled worker like a carpenter who would supervise the tasks on the

${ }^{231}$ Charles Auguste Hanauer. 1878. Études économiques sur l'Alsace ancienne et moderne (denrées et salaires). Paris : Société industrielle de Mulhouse, p.420.

232 Ibid, p.421.

233 Ibid, p.416.

${ }^{234}$ Pierre Chabat. 1881. Dictionnaire des termes employés dans la construction, volume II. Paris : V.E Morel et Cie Éditeurs, p.644.

235 Ernest Bosc. 1883. Dictionnaire raisonné d'architecture, Tome premier. Paris : Librairie de Firmin-Didot et Cie, p.404.

${ }^{236}$ Ibid, p.48 
construction yard would be paid so little. This supports my belief that the wage rate used for the gâcheur used by Allen must include some form of payment in-kind and that we cannot compare based on the data as presented. A correction is needed.

Such a correction can be made since Hanauer provides data for agricultural tasks by twentyfive year periods where the wage rates are divided according to nourris et non-nourris (fed and unfed). Numerous types of agricultural activities are represented: vignerons (wine-makers), faucheurs (mowers), journaliers d'été (summer laborers), journaliers d'hiver (winter laborers), moissonneurs (reapers), batteurs de grange (threshers). ${ }^{237}$ To be sure, there are some missing points. However, at Allen's 4.5 grams of silver per franc, none of the wage rates arrive below 2.88 grams per day for the workers who receive only monetary compensation (and not fed). In fact, they hardly come close. The closest to that threshold are the winter laborers (in 1726-1750 at 3.06 grams per day) and the batteurs de grange (in 1676 to 1700 at 3.26 grams per day). The only situations in which reported wage rates are below 2.88 grams concern wage rates where workers were fed by their employers. These tables suggest much more robust wage estimates. To obtain data that could be used to derive the welfare ratios, I took the wage rates in francs for all these agricultural tasks that were unskilled or semi-skilled (I excluded the vignerons), I indexed all the values to 1626-1650 (a year where all trades have one observation) and averaged those in order to obtain an index by which to fill the gaps. Table 3.9 below documents the results with those that were filled in underlined. However, I have been unable to determine which of these is the most representative of the average worker or have been unable to find a manner of weighing the wage by occupational distribution. Consequently, the "average journaliers" column will act as a high estimate of living standards in Strasbourg and the batteurs en grange will act as a low estimate. For skilled workers, there are similar problems. Allen uses Hanauer's aforementioned inscription of wages in Mulhouse from 1702 to 1761 which yield 0.80 francs per day (4.32 grams of silver per day) for masons in summer. Yet, the recapitulative twenty-five year figures proposed by Hanauer a few pages after-which require no interpolation — suggest much higher wage rates. ${ }^{238}$ The lowest rates found stand at 4.5 grams of silver per day in summer (a $4 \%$ gap) and the highest stands at 9.675 grams per day between 1701 and 1725 (a 123\% difference). Moreover, there are also wage rates for carpenters - which Allen also puts a rate of 4.32 grams per day. The rates proposed by Hanauer are also higher: 4.5 grams per day at the lowest point and the highest standing at 8.73 grams per day. There are also wage rates for skilled agricultural workers - the vigneronswhose wages are also above the 4.32 grams per day figure except between 1726 and 1750 when they are at 4.01 grams per day. Skilled workers in Strasbourg will be replaced with the maîtres charpentiers. Only with these corrections can I feel certain that I have properly represented the benchmark for living standards to New France. Table 3.10 below shows the wage rates for skilled

${ }^{237}$ Charles Auguste Hanauer. 1878. Études économiques sur l'Alsace ancienne et moderne (denrées et salaires). Paris : Société industrielle de Mulhouse, pp. 534-555.

${ }^{238}$ Ibid, p.421. 
workers in the periods of interest. I will use carpenters, but the others are there for those who want to replicate my work with different wage rates.

Table 3.9: Wages in Strasbourg for workers (with no in-kind payment) per day in grams of

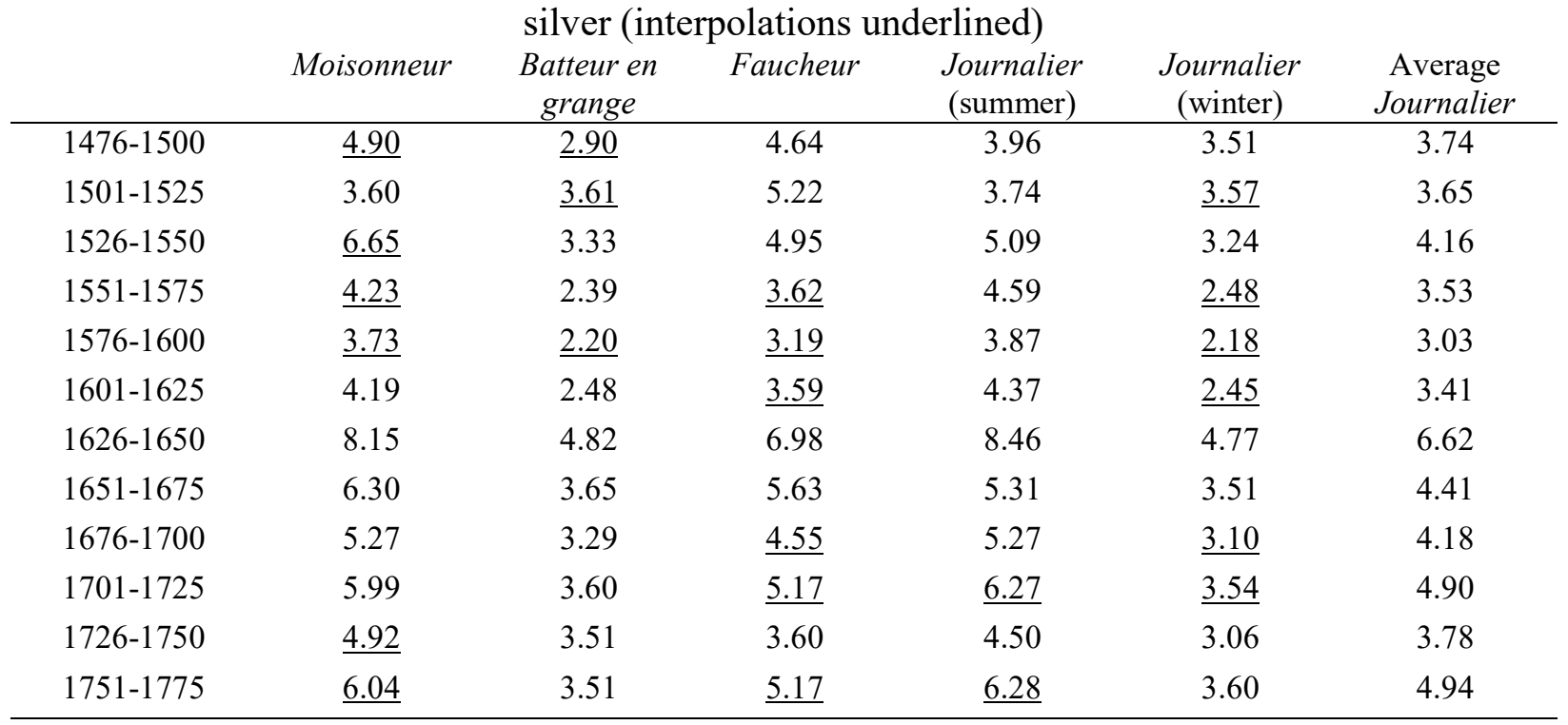

Table 3.10. Wages in Strasbourg for workers (with no in-kind payment for vignerons) per day in

\begin{tabular}{lccc} 
& \multicolumn{2}{c}{ grams of silver } & \\
& Vignerons & Masons & Master Carpenters \\
\hline $1676-1700$ & 4.55 & 8.73 & 8.73 \\
$1701-1725$ & 5.04 & 9.675 & 5.175 \\
$1726-1750$ & 4.01 & 4.5 & 4.5 \\
$1751-1775$ & 4.50 & 4.5 & 4.5 \\
\hline
\end{tabular}

The results for the bare bones basket (Tables 3.11 to 3.12) show that the inhabitants of New France did benefit from an advantage over their counterparts in France. During the era from 1688 to 1760 , the average inhabitant of the Canadian colony enjoyed a $16.8 \%$ advantage over the Parisian inhabitant. This is based on basket 1 derived in the previous section which is designed to make France and New France perfectly identical. Relative to poorer areas of France like Strasbourg, the comparisons are highly sensitive to the type of wage rates used. The advantage relative to the batteurs en grange is $22 \%$. Relative to the journaliers of Strasbourg, we fall to a disadvantage of $2.1 \%$. Obviously, the truth is between those two estimates given the seasonality of agricultural work. This suggests that at the very best, the inhabitants of New France enjoyed a slight living standards advantage at the bare bones levels. However, these advantages are nowhere near as large as those observed between the American colonies and Britain or between Spain and its colonies (see next section). 
Table 3.11. Welfare ratios (bare bones) in Paris and New France for unskilled workers Strasbourg

\begin{tabular}{lcccc} 
& Paris & (batteurs en grange) & Strasbourg (journaliers) & New France Basket \\
\hline $1688-1698$ & 2.28 & 1.50 & 1.92 & 2.52 \\
$1699-1708$ & 2.48 & 1.60 & 2.15 & 2.81 \\
$1709-1718$ & 2.15 & 2.04 & 2.77 & 2.10 \\
$1719-1728$ & 1.93 & 2.52 & 3.23 & 2.72 \\
$1729-1740$ & 1.92 & 2.26 & 2.43 & 2.65 \\
\hline $\mathbf{1 6 8 8 - 1 7 4 0}$ & $\mathbf{2 . 1 5}$ & $\mathbf{1 . 9 9}$ & $\mathbf{2 . 4 9}$ & $\mathbf{2 . 5 6}$ \\
\hline $1741-1750$ & 1.99 & 1.99 & 2.14 & 2.27 \\
$1751-1760$ & 1.81 & 1.98 & 2.79 & 1.88 \\
\hline $\mathbf{1 6 8 8 - 1 7 6 0}$ & $\mathbf{2 . 0 8}$ & $\mathbf{1 . 9 8}$ & $\mathbf{2 . 4 8}$ & $\mathbf{2 . 4 3}$ \\
\hline
\end{tabular}

Table 3.12. Relative bare bones welfare ratios for unskilled workers (New France / France) Strasbourg

\begin{tabular}{cccc} 
& Paris & (batteurs en grange) & Strasbourg (journaliers) \\
\hline $1688-1698$ & $110.4 \%$ & $167.7 \%$ & $131.6 \%$ \\
$1699-1708$ & $113.4 \%$ & $176.1 \%$ & $131.0 \%$ \\
$1709-1718$ & $97.7 \%$ & $103.0 \%$ & $75.6 \%$ \\
$1719-1728$ & $140.8 \%$ & $107.7 \%$ & $84.1 \%$ \\
$1729-1740$ & $137.7 \%$ & $117.3 \%$ & $108.9 \%$ \\
\hline $\mathbf{1 6 8 8 - 1 7 4 0}$ & $\mathbf{1 1 9 . 3 \%}$ & $\mathbf{1 2 9 . 1 \%}$ & $\mathbf{1 0 3 . 1 \%}$ \\
\hline $1741-1750$ & $113.9 \%$ & $114.3 \%$ & $106.1 \%$ \\
$1751-1760$ & $104.0 \%$ & $94.8 \%$ & $67.4 \%$ \\
\hline $\mathbf{1 6 8 8}-1760$ & $\mathbf{1 1 6 . 8 \%}$ & $\mathbf{1 2 2 . 3 \%}$ & $\mathbf{9 7 . 9 \%}$ \\
\hline
\end{tabular}

This portrait is insufficient as the bare bones basket is limited in the number and quantities of goods it contains. More precisely, it includes very few imported goods. In consequence, comparing the Canadians with the French with the bare bones basket is the equivalent of comparing goods produced in an economy with abundant land and scarce labour with an economy with abundant labour and scarce land. This is bound to be quite imperfect if taken as sole measure. Moving to the respectable basket solves a part of the problem. As we can see in Tables 3.13 and 3.14 below, the gap between France and New France disappears in great part when we take the "respectable" basket. Relative to Paris, the gap is non-existent and relative to Strasbourg, the gap shrinks to the possible point (if we believe that the journaliers wages are the most appropriate-although I prefer the batteurs en grange) of disappearing. 
Table 3.13. Welfare ratios (respectable) in Paris and New France for unskilled workers

\begin{tabular}{ccccc} 
& Paris & $\begin{array}{c}\text { Strasbourg } \\
\text { (batteurs en grange) }\end{array}$ & $\begin{array}{c}\text { Strasbourg } \\
\text { (journaliers) }\end{array}$ & New France (Full) \\
\hline $1688-1698$ & 0.79 & 0.51 & 0.65 & 0.86 \\
$1699-1708$ & 0.97 & 0.62 & 0.83 & 0.88 \\
$1709-1718$ & 0.86 & 0.73 & 0.99 & 0.54 \\
$1719-1728$ & 0.70 & 0.85 & 1.09 & 0.84 \\
$1729-1740$ & 0.78 & 0.78 & 0.84 & 0.90 \\
\hline $\mathbf{1 6 8 8 - 1 7 4 0}$ & $\mathbf{0 . 8 1}$ & $\mathbf{0 . 7 0}$ & $\mathbf{0 . 8 8}$ & $\mathbf{0 . 8 1}$ \\
\hline $1741-1750$ & 0.77 & 0.72 & 0.77 & 0.77 \\
$1751-1760$ & 0.77 & 0.71 & 0.97 & 0.77 \\
\hline $\mathbf{1 6 8 8 - 1 7 6 0}$ & $\mathbf{0 . 8 0}$ & $\mathbf{0 . 7 0}$ & $\mathbf{0 . 8 8}$ & $\mathbf{0 . 7 9}$ \\
\hline
\end{tabular}

Table 3.14. Relative respectable welfare ratios for unskilled workers (New France / France) Strasbourg

\begin{tabular}{cccc} 
& Paris & (batteurs en grange) & Strasbourg (journaliers) \\
\hline $1688-1698$ & $109.6 \%$ & $168.4 \%$ & $132.2 \%$ \\
$1699-1708$ & $90.8 \%$ & $142.1 \%$ & $105.4 \%$ \\
$1709-1718$ & $63.1 \%$ & $74.1 \%$ & $54.4 \%$ \\
$1719-1728$ & $120.3 \%$ & $98.4 \%$ & $76.8 \%$ \\
$1729-1740$ & $116.3 \%$ & $116.1 \%$ & $107.8 \%$ \\
\hline $\mathbf{1 6 8 8 - 1 7 4 0}$ & $\mathbf{9 9 . 3 \%}$ & $\mathbf{1 1 6 . 1 \%}$ & $\mathbf{9 2 . 4 \%}$ \\
\hline $1741-1750$ & $100.1 \%$ & $106.6 \%$ & $99.0 \%$ \\
$1751-1760$ & $99.3 \%$ & $108.5 \%$ & $78.8 \%$ \\
\hline $\mathbf{1 6 8 8 - 1 7 6 0}$ & $\mathbf{9 8 . 8 \%}$ & $\mathbf{1 1 2 . 9 \%}$ & $\mathbf{9 0 . 3 \%}$ \\
\hline
\end{tabular}

For skilled workers, the reality is quite different. Skilled workers in Canada gained much more than their relatives in France, regardless of the basket used. While unskilled workers did not enjoy a large return from moving to New France relative to their unskilled counterparts in France, skilled workers enjoyed a substantial premium. Our ratios above suggest that, at the bare bones level, unskilled workers were either on par on both sides of the Atlantic or that the inhabitants of New France enjoyed an advantage of $22 \%$. For skilled workers, the advantage is substantial and its width stood between $33 \%$ and $59 \%$ (see Tables 3.15 and 3.16). This suggests that the data presented here complies with the well known fact that skilled labor was very scarce in New France. Otherwise, there would not have been such a different gap between them and the one observed for unskilled workers. A similar situation appears for respectable baskets (Tables 3.17 and 3.18). 
Table 3.15. Welfare ratios (bare bones) in Paris and New France for skilled workers Strasbourg

\begin{tabular}{lccc} 
& Paris & (maîtres charpentiers) & New France \\
\hline $1688-1698$ & 4.12 & 4.00 & 4.77 \\
$1699-1708$ & 4.38 & 2.28 & 4.55 \\
$1709-1718$ & 3.75 & 2.93 & 4.80 \\
$1719-1728$ & 3.47 & 3.52 & 5.51 \\
$1729-1740$ & 3.25 & 2.90 & 5.64 \\
\hline $\mathbf{1 6 8 8 - 1 7 4 0}$ & $\mathbf{3 . 7 8}$ & $\mathbf{3 . 2 1}$ & $\mathbf{5 . 0 7}$ \\
\hline $1741-1750$ & 3.30 & 2.55 & 3.67 \\
$1751-1760$ & 3.13 & 2.54 & 4.61 \\
\hline $\mathbf{1 6 8 8 - 1 7 6 0}$ & $\mathbf{3 . 6 3}$ & $\mathbf{3 . 0 2}$ & $\mathbf{4 . 8 2}$ \\
\hline
\end{tabular}

Table 3.16. Relative bare bones welfare ratios for skilled workers (New France / France)

\begin{tabular}{ccc} 
& Paris & Strasbourg (maîtres charpentiers) \\
\hline $1688-1698$ & $115.8 \%$ & $119.4 \%$ \\
$1699-1708$ & $103.9 \%$ & $170.1 \%$ \\
$1709-1718$ & $128.1 \%$ & $163.9 \%$ \\
$1719-1728$ & $158.7 \%$ & $156.6 \%$ \\
$1729-1740$ & $173.5 \%$ & $194.9 \%$ \\
\hline $\mathbf{1 6 8 8}-1740$ & $\mathbf{1 3 4 . 1 \%}$ & $\mathbf{1 5 8 . 2 \%}$ \\
\hline $1741-1750$ & $111.1 \%$ & $144.1 \%$ \\
$1751-1760$ & $147.5 \%$ & $181.5 \%$ \\
\hline $\mathbf{1 6 8 8 - 1 7 6 0}$ & $\mathbf{1 3 2 . 8 \%}$ & $\mathbf{1 5 9 . 3 \%}$ \\
\hline
\end{tabular}

Table 3.17. Welfare ratios (respectable) in Paris and New France for skilled workers

\begin{tabular}{lccc} 
& Paris & $\begin{array}{c}\text { Strasbourg } \\
\text { (maîtres charpentiers) }\end{array}$ & New France Basket \\
\hline $1688-1698$ & 1.44 & 4.00 & 1.63 \\
$1699-1708$ & 1.76 & 2.28 & 1.43 \\
$1709-1718$ & 1.53 & 2.93 & 1.22 \\
$1719-1728$ & 1.28 & 3.52 & 1.71 \\
$1729-1740$ & 1.36 & 2.90 & 1.92 \\
\hline $\mathbf{1 6 8 8 - 1 7 4 0}$ & $\mathbf{1 . 4 7}$ & $\mathbf{3 . 2 1}$ & $\mathbf{1 . 6 0}$ \\
\hline $1741-1750$ & 1.31 & 2.55 & 1.25 \\
$1751-1760$ & 1.36 & 2.54 & 1.80 \\
\hline $\mathbf{1 6 8 8 - 1 7 6 0}$ & $\mathbf{1 . 4 3}$ & $\mathbf{3 . 0 2}$ & $\mathbf{1 . 5 8}$ \\
\hline
\end{tabular}


Table 3.18. Relative respectable welfare ratios for skilled workers (New France / France)

\begin{tabular}{ccc} 
& Paris & Strasbourg (maitres charpentiers) \\
\hline $1688-1698$ & $112.8 \%$ & $119.5 \%$ \\
$1699-1708$ & $81.6 \%$ & $142.0 \%$ \\
$1709-1718$ & $80.2 \%$ & $116.7 \%$ \\
$1719-1728$ & $133.2 \%$ & $144.1 \%$ \\
$1729-1740$ & $141.2 \%$ & $192.8 \%$ \\
\hline $\mathbf{1 6 8 8 - 1 7 4 0}$ & $\mathbf{1 0 8 . 7 \%}$ & $\mathbf{1 4 2 . 5 \%}$ \\
\hline $1741-1750$ & $95.6 \%$ & $135.5 \%$ \\
$1751-1760$ & $131.6 \%$ & $199.5 \%$ \\
\hline $\mathbf{1 6 8 8 - 1 7 6 0}$ & $\mathbf{1 1 0 . 1 \%}$ & $\mathbf{1 4 8 . 2 \%}$ \\
\hline
\end{tabular}

The main takeaway from this subsection on the France and New France comparison is that, in spite of very different economies, living standards are by no means as high in New France relative to France as many expected them to be. At the bare bones level, there was a slight advantage for the inhabitant of New France. However, this is mainly because of the nature of the respective economies. Land intensive goods were considerably cheaper in New France than in France. For example, in the long peace period of 1713 to 1740 , the average daily wage of an unskilled work in Paris bought $7.33 \mathrm{~kg}$ of oats compared with $17.66 \mathrm{~kg}$ in New France. Capital intensive goods like butter (which required the importation of the cows), cloth and wine are much different. In Paris, one day's work bought $2.1 \mathrm{~kg}$ of butter, 1.05 meters of cloth and 4.86 liters of wine. In New France, these figures stood at $1.36 \mathrm{~kg}$ of butter, 0.43 meters of cloth and 1.58 liters of wine. As a result, it seems fair to say that the inhabitants of New France could more easily satisfy their basic needs. However, rising beyond that point was harder. Any advantage enjoyed at the bare bones level disappears at the respectable level. The situation was slightly different for skilled workers who enjoyed substantial gains for both types of basket. However, since the majority of the population was unskilled, the vast majority of New France's population was poorer than the average French worker. Table 3.19 summarizes these results.

Two other points are worth mentioning. The first is that I believe that these gaps as overstating the relative advantage of the French-Canadians. In the next chapter, I intend to show how playing with some assumptions of the consumption baskets could widen the gap between France and New France. Secondly, I included Strasbourg in the discussion to avoid comparing only with Paris. However, I did mention earlier that very few immigrants to New France came from outside Northern France and Paris. As a result, I did not believe Strasbourg to be fully representative. The advantage of the Strasbourg wages is that they were reported for rural workers which are more easily comparable with the wages I have for New France. Nonetheless, I would have much preferred wages from Normandy and Brittany. 
Table 3.19. Difference between New France and France from 1688 to 1760

\begin{tabular}{|c|c|c|c|c|c|c|}
\hline & $\begin{array}{l}\text { Paris / New } \\
\text { France (bare } \\
\text { bones } 1 \text { ) }\end{array}$ & $\begin{array}{c}\text { Paris / New } \\
\text { France } \\
\text { (Respectable) }\end{array}$ & $\begin{array}{c}\text { Strasbourg } \\
\text { (batteurs en } \\
\text { grange)/ } \\
\text { New France } \\
\text { (bare bones } \\
\text { 1) }\end{array}$ & $\begin{array}{c}\text { Strasbourg } \\
\text { (batteurs en } \\
\text { grange) / } \\
\text { New France } \\
\text { (Respectable) }\end{array}$ & $\begin{array}{c}\text { Strasbourg } \\
\text { (journaliers) } \\
\text { / New France } \\
\text { (bare bones } \\
\text { 1) }\end{array}$ & $\begin{array}{c}\text { Strasbourg } \\
\text { (journaliers) } \\
\text { / New France } \\
\text { (Respectable) }\end{array}$ \\
\hline All periods & $+16.8 \%$ & $-1.2 \%$ & $+22.3 \%$ & $+12.9 \%$ & $-2.1 \%$ & $-9.7 \%$ \\
\hline
\end{tabular}

Note: if positive, New France is richer and if negative, New France is poorer.

\subsection{Welfare ratios comparison between the Colonial United States, England, Latin America and New France}

Differences between the old continent and Canada are liable to a large problem in the sense that the economies of the old world were labor-abundant and land-constrained - which was the opposite of Canada. Hence, there is a need to compare with other North American regions where land was also abundant. In many regards, this comparison is easier to enact. First of all, we do not have the problem of differences in fuel requirements which was a problem in the comparison with France. Indeed, as pointed out earlier, the figures for firewood consumption indicate similar quantities of fuel consumption in the middle colonies as in New England and as in New France. Secondly, due to environmental similarities, agriculture would command labor only in summers and there would very little winter cropping or herding as was the case in France or England. ${ }^{239}$ Consequently, the labor markets shared important features. The two economies also shared features in terms of family size. Family sizes were actually quite similar which makes the use of welfare ratios quite well-suited for these two societies. ${ }^{240}$

Obviously, the Catholicism, French language and legal institutions of New France can strike readers as being gigantic differences. However, similarities are easier to find than the differences. These regions are easily comparable, especially Boston and Quebec given the similar climate. There are no reasons to find large differences in diets and calorie consumption. For example, John Komlos has found that slaves in colonial America consumed roughly 2800 calories per day-a "low intake by subsequent standards reached in America". ${ }^{241}$ Sarah McMahon on the other hand used wills to see the average food allowance provided to widows and found estimates ranging

\footnotetext{
239 John McCusker and Russell Menard. 1985. The Economy of British America, 1607-1789. Chapel Hill, NC: University of North Carolina Press, p.238.

240 Jean-Louis Flandrin. 1979. Family in Former Times: Kinship, Household and Sexuality. Cambridge: Cambridge University Press, p. 55.

${ }^{241}$ John Komlos. 1994. "The height of Runaway Slaves in Colonial America" in Stature, Living Standards and Economic Development: Essays in Anthropometric history eds. John Komlos, Chicago: University of Chicago Press, pp. 93-116.
} 
between 2386 and 2831 calories per day between the periods of 1654-1698 to $1740-1759 .^{242}$ James Lemon reports that Pennsylvania between 1740 and 1790, the daily intake stood at 2877 calories. $^{243}$ These numbers are similar to those in New France. Both economies could easily produce the basic stuff of subsistence, but most luxuries would have to be imported from other colonies or from the mother country in the case of manufactured goods. While the similarities between the northern part of the American colonies (we will exclude any focus on the slave economies of the south which would add needless complexity to this analysis) and French Canada are numerous, the problem of accurate data is more acute in the case of the American colonies. While in Canada, the issue had been too few historians pouring over the archival data to generate some estimates of growth, the early colonial era for the United States is plagued by few primary sources that can be used to generate measures of economic growth, living standards, prices and inequalities. While there are many attempts at providing estimates for all of these measures, they are very often based on limited datasets. Only after the 1790s does the quality of sources improve significantly.

Prudence ought to be exercised in the course of charting the comparisons between New England and the Middle Colonies with New France. The main attempt, in terms of welfare ratios, to generate comparisons of living standards in the American colonies have stemmed from two sides. One is from the aforementioned Robert Allen, Tommy Murphy and Eric Schneider ${ }^{244}$ while the second stems from Jeffrey Williamson and Peter Lindert. ${ }^{245}$ Hopefully, the two articles use the same baskets as Allen and al. shared their basket with Lindert and Williamson. Both exercise great caution in the use of the data, yet there are some points of contention and correction that I must address before proceeding with my comparisons.

The first issue is with the amount of firewood attributed - a topic already discussed. In short, the allotment of $2 \mathrm{MBTU}$ in the basket is very restrictive and is not representative of the reality imposed by the harsh climate of New England and New France. An increase in the attribution of fuel requirements is necessary. The second issue is with using maize as a food item. Allen and al. opted for a basket where maize was the main food component. This was meant to allow comparisons with Latin America where maize was a popular crop. However, it was not the main crop of consumption in New England. Rye and oats also took an important share. ${ }^{246}$ Meanwhile

\footnotetext{
${ }^{242}$ Sarah McMahon. 1985. "A comfortable subsistence: the changing composition of diet in Rural New England", William \& Mary Quarterly, Vol. 42, No.1, pp.26-65.

243 James Lemon. 1972. The Best Poor Man's Country: a Geographical Study of Early Southeastern Pennsylvania. Washington D.C.: Johns Hopkins University Press, p.155.

${ }^{244}$ Robert Allen, Tommy Murphy and Eric Schneider. 2012. "The Colonial Origins of the Divergence in the Americas: A Labor Market Approach", Journal of Economic History, Vol. 72, No. 4, pp.863-94.

${ }^{245}$ Peter Lindert and Jeffrey Williamson. 2014. American Colonial Incomes, 1650-1774. Cambridge, MA : National Bureau of Economic Research

${ }^{246}$ Sarah McMahon. 1985. "A comfortable subsistence: the changing composition of diet in Rural New England", William \& Mary Quarterly, Vol. 42, No.1, p.30-33.
} 
the blé d'inde (corn) was never popular in New France. However, oats and maize would have served the purpose of assuring the meanest form of subsistence in New France and New England. Thus, maize and oats are used for the bare bones basket, but wheat will be issued for the respectable basket. I will also extend the same results to include England. The baskets that will be used are presented in Tables 3.20 and 3.21.

Table 3.20. Baskets at the bare bones level in North America

\begin{tabular}{cccc} 
& Colonial America (high) & New France(high) & England \\
\hline Oats & - & $153.96 \mathrm{~kg}$ & $153.96 \mathrm{~kg}$ \\
Maize & $165 \mathrm{~kg}$ & - & - \\
Wheat & - & - & - \\
Peas & $20 \mathrm{~kg}$ & $20 \mathrm{~kg}$ & $20 \mathrm{~kg}$ \\
Meat & $5 \mathrm{~kg}$ & $5 \mathrm{~kg}$ & $5 \mathrm{~kg}$ \\
Butter & $3 \mathrm{~kg}$ & $3 \mathrm{~kg}$ & $3 \mathrm{~kg}$ \\
Soap & $1.3 \mathrm{~kg}$ & $1.3 \mathrm{~kg}$ & $1.3 \mathrm{~kg}$ \\
Cloth & $3 \mathrm{~meters}$ & 3 meters & $3 \mathrm{~meters}$ \\
Candles & $1.3 \mathrm{~kg}$ & $1.3 \mathrm{~kg}$ & $1.3 \mathrm{~kg}$ \\
Lamp oil & 1.3 liters & 1.3 liters & 1.3 liters \\
Fuel & 20 MBTU & 20 MBTU & 2 MBTU \\
\hline
\end{tabular}

Source: the weights are based upon Robert Allen, Tommy Murhphy and Eric Schneider. 2012. "Appendix: Colonial Origins of the Divergence in the Americas", Journal of Economic History, Vol. 72, No. 4, p.7

Table 3.21. Baskets at the respectable level

\begin{tabular}{cccc} 
& British North America & French North America & England \\
\hline Wheat & $201.35 \mathrm{~kg}$ & $201.35 \mathrm{~kg}$ & $201.35 \mathrm{~kg}$ \\
Beans or Peas & $39.45 \mathrm{~kg}$ & $39.45 \mathrm{~kg}$ & $39.45 \mathrm{~kg}$ \\
Meat & $26 \mathrm{~kg}$ & $26 \mathrm{~kg}$ & $26 \mathrm{~kg}$ \\
Butter & $10.4 \mathrm{~kg}$ & $10.4 \mathrm{~kg}$ & $5.2 \mathrm{~kg}$ \\
Cheese & - & - & $5.2 \mathrm{~kg}$ \\
Eggs & 52 eggs & 52 eggs & $52 \mathrm{eggs}$ \\
Wine & - & 68.251 & - \\
Beer & - & - & 1821 \\
Rum & 27.11 & - & - \\
Soap & $2.6 \mathrm{~kg}$ & $2.6 \mathrm{~kg}$ & $2.6 \mathrm{~kg}$ \\
Linen & $5 \mathrm{~m}$ & $5 \mathrm{~m}$ & $5 \mathrm{~m}$ \\
Candles & $2.6 \mathrm{~kg}$ & $2.6 \mathrm{~kg}$ & $2.6 \mathrm{~kg}$ \\
Lamp oil & 2.61 & 2.61 & 2.61 \\
Fuel & $30 \mathrm{MBTU}$ & $30 \mathrm{MBTU}$ & $5 \mathrm{MBTU}$ \\
\hline
\end{tabular}

Source: the weights are based upon Robert Allen, Tommy Murhphy and Eric Schneider. 2012. "Appendix: Colonial Origins of the Divergence in the Americas", Journal of Economic History, Vol. 72, No. 4, p.7

The reason I am recreating the baskets rather than using the Allen data as it stands is because I do not have bread prices and I have to use kilograms of oats or wheat to make my measures. The prices for England were taken from the work of Allen. ${ }^{247}$ The aim was to include England to

\footnotetext{
${ }^{247}$ Robert C.Allen. 2001. "The great divergence in European wages and prices from the Middle Ages to the First
} World War" Explorations in economic history, Vol.38, No.4, pp.411-447. 
compare the gap between France and New France to the gap between New England and England. In general, in my attempt to recreate the basket costs for Boston and Philadelphia I relied on Allen et al. ${ }^{248}$ However, I enacted some modifications. The price of wheat was interpolated according to moving average of two periods that were missing up to 1721. After 1721, wheat prices for Boston follow the wholesale price movements proposed by Arthur Cole. ${ }^{249}$ The last modification from Allen and al. relates to clothing. They did not possess clothing prices prior to 1747 in the American colonies. They assume a constant price up to 1753. They mention that "most cloth was imported from England and could be transported to Massachusetts, Pennsylvania and Maryland at similar cost". ${ }^{250}$ Yet, the price level they compute seems to be somewhat too high. Colonists would tend to wear mixed garments of clothing whose prices tended to be lower than those suggested. ${ }^{251}$ The historian William B. Weedon suggested that in 1713, one yard of plain cloth and one yard of checkered shirting all sold at 1.25 shillings. ${ }^{252}$ Given that one yard represents 0.9144 meter, it means that the price per meter stood at 1.367 shillings. Using the exchange rate of 3.7127 grams of silver per shilling proposed by Lindert and Dietrich, this means a price of 5.08 grams per meter. Much closer to levels observed in New France for similar types of quality (see Appendix 1 for a discussion of clothing quality). This price for 1713 was indexed to the price movements of linen in England. ${ }^{253}$ This results in a price for clothing closer to the reality of consumers.

One important final justification has to be made here which concerns the wage rates used. Through the process of computing these indexes anew in order to make some modifications to insure reliability, it was discovered that the original source, Gloria Main's work, used by Allen and al. had quoted the wage rates per day in pence sterling rather than pence of the colonial currency. ${ }^{254}$ Using the conversion rates from sterling to grams of silver proposed by Lindert and

\footnotetext{
${ }^{248}$ Robert Allen, Tommy Murhphy and Eric Schneider. 2012. "Appendix: Colonial Origins of the Divergence in the Americas", Journal of Economic History, Vol. 72, No. 4.

${ }^{249}$ Arthur H.Cole.1938. Wholesale Commodity Prices in the United States, 1700 -1861, Statistical Supplement, Actual Wholesale Prices of Various Commodities. Cambridge, MA: Harvard University Press. Available online at: http://www.vanderbilt.edu/econ/cipr/cole-historical-data.html. Weight conversion for maize was enacted on the basis of 56 pounds of 454 grams per minot, 1.107 bushels per minot and 39.025 liters per minot.

${ }^{250} \mathrm{Ibid}, \mathrm{p} .21$.

${ }^{251}$ Readers interested in the issue should consult two key works on the issue of clothing quality in comparisons. The first is the chapter in Kax Wilson's work devoted to colonial America. It details both the production of cloth in the colonies and the consumption of clothing (Kax Wilson.1979. A History of Textiles. Boulder, CO: Westview Press, pp.234-242). The second is Linda Baumgarten's work on clothing in colonial and federal America (Linda Baumgarten. 2002. What Clothes Reveal: The Language of Clothing in Colonial and Federal America. New Haven, CT: Yale University Press). Chapter 4 in her book is particularly insightful and it was the source which lead me to believe that Allen and al. overstated the cost of clothing in Boston.

${ }^{252}$ William Babcock Weedon. 1890 [2011]. Economic and Social History of New England, 1620-1789. London: British Library Historical Print Editions, pp. 890

${ }^{253}$ Gregory Clark. 2005. "The condition of the working class in England, 1209-2004", Journal of Political Economy, vol.113, no.6, pp.1307-1340.

${ }^{254}$ The wage rates for New England come from Gloria Main. 1994. "Gender, Work and Wages in Colonial New England", William \& Mary Quarterly, Vol.51, No.1, p. 48. Note: the author is clear as to her data conversion when
} 
Williamson ${ }^{255}$, the average wage level in grams of silver is roughly $20 \%$ higher than that proposed by Allen and al. When the wage rates proposed by Main are deflated according to the exchange rates to silver for the colonial currency rather than the sterling currency, the differences disappear. The other possibility is that they used the wage rates for farm boys which were also quite close to those they suggested in terms of grams of silver. Yet, they seem to argue that they did not use that series. Either of the two errors is possible. ${ }^{256}$ This suggests that the wage rate in Boston was higher than otherwise suggested. I will use the proper wage rate. As for Philadelphia, the wage rates come from the work of Gary Nash. ${ }^{257}$ I suspect that the level they suggest is probably a little too high. In addition, the wage levels proposed for Boston are probably lower than they actually were. In his work on Essex county farmers and fishermen, Daniel Vickers proposes different wages. For our period of concern, the average wage rates for winter, summer and harvest seasons stand between 1.14 shillings per day (winter wages) and 1.43 shillings per day (harvest wages) while the source used by Gloria Main proposed 1.39 shillings per day. Moreover, the wage rates differ dramatically by period with Vickers' wages being above the Main wages for summer work up to 1725 and then below, while the harvest wages are above or equal to Main's wages up to 1734 and after $1754 .^{258}$

In the case of Philadelphia, the wages will be derived from the work of Gary Nash ${ }^{259}$ and combined with the price data of Pennsylvania prices available at the Global Price and Income History Group. ${ }^{260}$ The key commodities of interest are similar to those used in the case of France and need to be internationally traded or be the result of the non-agricultural sector within the colonies. among these commodities are rum, sugar, salt, tobacco, cloth and codfish.

As for wages in England, I preferred to rely on Allen's wage for agricultural workers in Southern England. Normally, the wage rate for construction workers is used-which stands at a level much higher than those observed for agricultural workers. The problem is that Judy

she states that "the original data are in a variety of local currencies and have been deflated to sterling equivalents by means of exchange rates" (p.46).

255 Peter Lindert and Jeffrey Williamson. 2014. American Colonial Incomes, 1650-1774. Cambridge, MA: National Bureau of Economic Research - the datafiles are available online at http://gpih.ucdavis.edu/tables.htm under the title "Allen subsistence bundle costs, colonial America versus England, as of 2013" (direct link).

${ }^{256}$ Robert Allen, Tommy Murhphy and Eric Schneider. 2012. "Appendix: Colonial Origins of the Divergence in the Americas", Journal of Economic History, Vol. 72, No. 4, p.4.

257 The wage rates for Philadelphia come from Gary B. Nash. 1979. Urban Crucible: Social Change, Political Consciousness, and the Origins of the American Revolution. Cambridge, MA: Harvard University Press, p.392-394.

258 Daniel Vickers. 1994. Farmers and Fishermen: Two Centuries of Work in Essex County, Massachusetts, 16301850. Chapel Hill, NC: University of North Carolina Press, p. 248.

${ }^{259}$ Gary B. Nash. 1979. Urban Crucible: Social Change, Political Consciousness, and the Origins of the American Revolution. Cambridge, MA: Harvard University Press, p.392-394. Note: The value of 1727 was used as wages for all years from 1720 to 1726 . All other gaps were interpolated using the average of the two closest years between which the missing years were situated.

260 Available online at the Global Price and Income History Group, Pennsylvania spliced series, 1720-1896, http://gpih.ucdavis.edu/Datafilelist.htm 
Stephenson uncovered that the wage rates for London construction workers were overestimated by roughly $20 \%{ }^{261}$ This is because the wage rates reported came from account books of construction entrepreneurs who included an overhead for each worker in their contracts. This overhead was not given as wages to workers. As a result, England's wages were well below the levels suggested by Allen (according to Stephenson). Having being convinced by the argument of Stephenson, I preferred Clark's agricultural workers from Southern England. This will explain why, as some readers will notice, the welfare ratios for England are not above those for Paris (where I only had wages for unskilled construction workers in the city- thus the England wages are rural and agricultural and the Paris wages are urban and construction-related). The wages used for New France, England and Colonial America are the most comparable as they are rural and agricultural (except for Philadelphia but, as Lindert and Williamson observed, rural-urban real wage gaps were very small during the colonial era-less than $10 \%$ ). The results are presented in Tables 3.22 and 3.23. A summary of the differences (expressed in percentages) can be seen in Table 3.24.

Table 3.22: Welfare ratios (bare bones) of unskilled workers in New France, Boston, Philadelphia and

\begin{tabular}{ccccc} 
& New France & $\begin{array}{c}\text { England } \\
\text { Boston }\end{array}$ & Philadelphia & England \\
\hline $1688-1698$ & 2.52 & 3.65 & - & 2.59 \\
$1699-1708$ & 2.81 & 3.58 & - & 2.51 \\
$1709-1718$ & 2.10 & 2.81 & - & 2.51 \\
$1719-1728$ & 2.72 & 3.25 & 3.50 & 2.57 \\
$1729-1740$ & 2.65 & 3.84 & 3.71 & 2.55 \\
$\mathbf{1 6 8 8 - 1 7 4 0}$ & $\mathbf{2 . 5 6}$ & $\mathbf{3 . 4 5}$ & $\mathbf{3 . 6 2}$ & $\mathbf{2 . 5 5}$ \\
$1741-1750$ & 2.27 & 3.37 & 3.35 & 2.50 \\
$1751-1760$ & 1.88 & 2.76 & 3.44 & $\mathbf{2 . 5 2}$ \\
$\mathbf{1 6 8 8 - 1 7 6 0}$ & $\mathbf{2 . 4 3}$ & $\mathbf{3 . 3 4}$ & $\mathbf{3 . 5 1}$ & \\
\hline
\end{tabular}

Table 3.23: Welfare ratios (respectable) of unskilled workers in New France, Boston, Philadelphia and

\begin{tabular}{ccccc} 
& New France & $\begin{array}{c}\text { England } \\
\text { Boston }\end{array}$ & Philadelphia & England \\
\hline $1688-1698$ & 0.86 & 1.38 & - & 0.80 \\
$1699-1708$ & 0.88 & 1.29 & - & 0.91 \\
$1709-1718$ & 0.54 & 1.05 & - & 0.82 \\
$1719-1728$ & 0.84 & 1.25 & 1.65 & 0.87 \\
$1729-1740$ & 0.90 & 1.68 & 1.72 & 0.93 \\
$\mathbf{1 6 8 8 - 1 7 4 0}$ & $\mathbf{0 . 8 1}$ & $\mathbf{1 . 3 4}$ & $\mathbf{1 . 6 9}$ & $\mathbf{0 . 8 7}$ \\
$1741-1750$ & 0.77 & 1.43 & 1.48 & 0.95 \\
$1751-1760$ & 0.73 & 1.08 & 1.63 & 0.84 \\
$\mathbf{1 6 8 8 - 1 7 6 0}$ & $\mathbf{0 . 7 9}$ & $\mathbf{1 . 3 2}$ & $\mathbf{1 . 6 2}$ & $\mathbf{0 . 8 7}$ \\
\hline
\end{tabular}

\footnotetext{
${ }^{261}$ Judy Stephenson. 2014. Gilboy revisited: or low(er) wages and the pre-industrial London building craftsman. Communication presented at the Economic History Society 2014 conference in Warwick.
} 
Table 3.23: New France's relative standing (as \% of other area) to Paris, Strasbourg, England and the

\begin{tabular}{cccccc} 
& \multicolumn{5}{c}{ American Colonies } \\
& Paris & Strasbourg & England & Boston & Philadelphia \\
\hline Bare bones & $116.8 \%$ & $97.9 \%$ to $122.3 \%$ & $96.4 \%$ & $72.8 \%$ & $56.8 \%$ \\
Respectable & $98.8 \%$ & $90.3 \%$ to $112.9 \%$ & $90.9 \%$ & $65.8 \%$ & $48.7 \%$ \\
\hline
\end{tabular}

In all instances, shifting from the bare bones basket to the respectable basket worsens the relative comparison for New France. For example, living standards in New France are only equal to $72.8 \%$ of those in Boston and $56.8 \%$ of those in Philadelphia. At the respectable level, New France's position falls to $65.8 \%$ and $48.7 \%$ of the living standards observed in Boston and Philadelphia relative to England. In addition, the inhabitants of Boston enjoy an advantage relative to England with regard to the respectable basket, which is not the case when I compare the inhabitants of New France with those of France (at the respectable level, the data suggests near equality). These numbers probably understate the gaps between New France and other areas. One way to see this is to invert the welfare ratios like Paul Sharp and Jacob Weisdorf did. ${ }^{262}$ Rather than measuring the welfare ratios by multiplying wages by 250 days, I can divide the cost of the basket by the wage rate to see how many days are required to acquire said basket. This approach basically provides a first control for the length of the work year. As can be seen in Table 3.24, the number of work days required to buy one basket is much smaller. In fact, all areas (except maybe Strasbourg) require fewer days of work to achieve the respectable basket. If the inhabitant of New France could not increase the time they worked by a significant extent relative to their counterparts elsewhere, the differences in welfare ratios would be much greater than suggested above.

Table 3.24: Difference between New France, England, France and Colonial America, 1688 to 1760

\begin{tabular}{ccccccc} 
& Paris & Strasbourg & England & Boston & Philadelphia & New France \\
\hline Bare bones & 124.7 days & $\begin{array}{c}106.0 \text { to } 132.3 \\
\text { days }\end{array}$ & 136.5 days & 79.4 days & 59.4 days & 112.5 days \\
Respectable & 312.8 days & $\begin{array}{c}297.2 \text { to } 370.1 \\
\text { days }\end{array}$ & 289.6 days & 201.5 days & 155.5 days & 349.6 days \\
$\begin{array}{c}\text { Ratio bare } \\
\text { bones } \\
\begin{array}{c}\text { Ratio } \\
\text { respectable }\end{array}\end{array}$ & $110.9 \%$ & $\begin{array}{c}94.3 \% \text { to } 117.6 \% \\
121.4 \%\end{array}$ & $70.6 \%$ & $52.8 \%$ & \\
\hline
\end{tabular}

Two points are especially important and require a discussion. The first is the most important as it concerns the debate on the colonial origins of divergence. Without replicating the results for Latin America, we can simply look at the underlying data for Allen et al. In their data, the bare bones welfare ratio for Boston between 1688 and 1760 was 2.95. Once I correct for the misunderstanding in the use of Gloria Main's wages for New England, I find a figure for Boston of 3.66 (not far from my own 3.34) between 1688 and 1760. As a ratio of what was observed in Latin America, we can see that New France was not the poorest in all the Americas. However, that did not mean that it fared well. As Table 3.25 shows, relative to Boston, New France was richer

\footnotetext{
${ }^{262}$ Paul Sharp and Jacob Weisdorf. 2012. "French revolution or industrial revolution? A note on the constrasting experiences of England and France up to 1800", Cliometrica, Vol.6, No.1, pp.79-88.
} 
than Potosi, Rural Mexico and Bogota but poorer than Urban Mexico. Given the importance attributed to the colonial origins of income differences between Latin America and the North America, finding differences of a somewhat smaller magnitude within North America is an important discovery. It means that divergence was not a "north versus south" story. It was a story of "the English-speaking world versus everybody else in the Americas". And the comparisons with Allen and al. are probably conservative. Data collected by Leticia Arroyo Abad, Elwyn Davies and Jan Luiten van Zanden show that welfare ratios in Buenos Aires were appreciably higher than elsewhere in Latin America which would deteriorate New France's ranking if included. ${ }^{263}$ Although it is beyond the scope of this paper, future researchers could gain from the consolidation of data sources to measure standardized living standards during the eighteenth century across the Americas. In addition, I believe that the figures contained below probably understate living standards in Latin America. ${ }^{264}$ The main reason relates to fuel and food requirements. In the cold weathers of Canada, the maintenance of body mass requires a greater intake of calories than in the warmer weathers of Latin America. In the next chapter, I will detail this point further, but suffice it to say that calories would have to be greater in numbers for New England and New France than in Latin America in order to make the two baskets comparable. In the presence of such modifications, the relative position of Latin America would improve slightly and New France's relative position would deteriorate.

\footnotetext{
${ }^{263}$ Leticia Arroyo Abad, Elwyn Davies and Jan Luiten van Zanden. 2012. "Between conquest and independence: real wages and demographic change in Spanish America, 1530-1820", Explorations in Economic History, Vol.49, no.2, p.157.

${ }^{264}$ Some authors have criticized the use of welfare ratios for Latin America (see Rafael Dobado-Gonzalez. 2015. "PreIndependence Spanish Americans: Poor, Short and Unequal ... or the Opposite", Revista de Historia Económica/Journal of Iberian and Latin American Economic History, Vol.33, no.1, pp.15-59. However, I have failed to be convinced by this rebuttal. The replies offered by Leticia Arroyo Abad, Jan Luiten Van Zanden, Robert Allen, Eric Schneider and Tommy Murphy provide the full defense of welfare ratios (see: Leticia Arroyo Abad and Jan Luiten Van Zanden. 2015. "Optimistic but Flawed? A reply" Revista de Historia Económica/Journal of Iberian and Latin American Economic History, Vol.33, no.1, pp.77-82; Robert Allen, Tommy Murphy and Eric Schneider. 2015. "Una de cal y otra de arena: building comparable real wages in a global perspective." Revista de Historia Económica/Journal of Iberian and Latin American Economic History, Vol.33, no.1, pp.61-75. My criticisms of welfare ratios are much more mundane and relate to the issue of comparability related to family size and adjusting requirements by regions. The first has been partly answered in the work of Eric Schneider (2013. "Real Wages and the Family: Adjusting Real Wages to Changing Demography in Pre-Modern England", Explorations in Economic History, Vol.50, no.1, pp.99-115). The second issue has been addressed in part here with regard to fuel in households. However, I intend to return to this issue later. One relevant solution for future research would be to use information about temperature, housing types (wood, stone, bricks) and evaluate energy losses in heating. This could create a more precise measurement. The rest of my criticism hinges on nutritional requirements at different latitudes and temperatures (see section 4.8 of this dissertation).
} 
Table 3.25. Living Standards in Latin America and New France compared to Boston

Comparison Ratio

\begin{tabular}{cc}
\hline Potosi (Allen et al. 2012) & $45.4 \%$ \\
Rural Mexico (Allen et al. 2012) & $49.9 \%$ \\
Bogota (Allen et al. 2012) & $54.1 \%$ \\
Quebec (this dissertation) & $72.7 \%$ \\
Urban Mexico (Allen et al. 2012) & $84.7 \%$ \\
\hline
\end{tabular}

The second point of importance is that of the difference between the bare bones and respectable baskets. The difference can be explained by significant differences in productivity. Under international trade theory, prices for internationally traded goods would have been roughly similar while non-traded goods would have had lower prices in less productive economies. ${ }^{265}$ For New France, capital-intensive goods (salt, sugar, tobacco, wine) and manufactured goods (clothing) tended to be imported and were thus traded at international prices. Land intensive goods (i.e. agricultural products) were not traded in high volumes until the early nineteenth century. As a result, prices for food items would reflect local conditions in New France. Thanks to the great abundance of land, basic food prices would be very low relative to wages.

By this reasoning, regional differentials in productivity would be captured in the ability to purchase internationally traded goods. It also means that baskets with considerable amounts of locally produced food items would hide differences. This intuition is drawn from the work of Stephen Broadberry and Bishnupriya Gupta who argued that the gap between silver wages and grain wages (wages divided by a unit of locally produced food) can actually be used as a measure of development. ${ }^{266}$ Grain wages could be equal across space but silver wages would differ thanks to differences in productivity. The area with higher silver wages would be able to consume more internationally traded goods so that consumption would be greater. In addition, this would also mean that domestically produced goods which competed on export markets (like codfish) ${ }^{267}$ would

${ }^{265}$ Bela Balassa. 1964. "The Purchasing-Power Parity Doctrine: A Reappraisal”, Journal of Political Economy, Vol. 72, no.6, pp.584-596.

${ }^{266}$ Stephen Broadberry and Bishnupriya Gupta. 2006. "The Early Modern Great Divergence: Wages, Prices and Economic Development in Europe and Asia, 1500-1800", Economic History Review, Vol.59, no.1, pp.2-31.

267 Those interested in discussions of those price series can consult the following articles: Ruth Crandall. 1934. "Wholesale Commodity Prices in Boston during the Eighteenth Century", Review of Economics and Statistics, Vol.16, No.6, pp.117-128; Daniel Vickers. 1996. "The Price of Fish: A Price Index for Cod, 1505-1892", Acadiensis, Vol. 25, No. 2, pp.92-104; Christopher Magra. 2006. The New England Cod Fishing Industry and Maritime Dimensions of the American Revolution. Pittsburgh, PA, PhD Thesis, Department of History, University of Pittsburgh. Note : It should be underlined that the prices I used are also available online at the Global Price and Income History Group under the title Massachusetts, 1630-1883 at the following address : http://gpih.ucdavis.edu/files/Massachusetts 1630-1883a.xls (consulted September 11th 2014). The category of "merchantable cod" here refers to dried cod after transformation (net weight after evisceration). To make the price series comparable, I used the conversions proposed by François Rousseau.1983. L'Oeuvre de Chère en Nouvelle-France : Le Régime des Malades à l'Hôtel-Dieu de Québec. Québec: Presses de l'Université Laval, p.395. According to Rousseau, one poignée of codfish (2 cod) when dried and eviscerated weighed $1.02 \mathrm{~kg}$ (510 g per fish). It according to his specifications that I enacted the conversions. The work of James Lydon is also very useful in that regard (James Lydon. 2008. Fish and Flour for Gold, 1600-1800: Southern Europe in the Colonial Balance of Payments. Philadelphia, PA: Library Company of Philadelphia). 
be pricier for the inhabitants of a less productive country. One way to illustrate this would be to divide wage rates by the cost of each given unit in different regions. The period of 1713 to 1740 lends itself nicely to this exercise. It was a long period of peace with few international trade perturbations. As a result, I am not capturing any differences that would be caused by adverse supply shocks in times of war. What emerges is that there are large differences in productivity between the American colonies and New France. As can be seen in Table 3.26, for basic foodstuffs, the differences are minimal except that Philadelphia is ahead of the group. However, once I move to internationally traded goods and manufactured (which represent the bulk of the respectable basket), New France's position is clearly behind those of Pennsylvania and New England. Consumption capacities for all items are substantially behind.

Table 3.26. Quantities of goods acquired in a day's work

\begin{tabular}{cccc} 
& Boston & Philadelphia & New France \\
\hline Wheat & $11.22 \mathrm{~kg}$ & $16.63 \mathrm{~kg}$ & $11.88 \mathrm{~kg}$ \\
Peas & $10.33 \mathrm{~kg}$ & $22.39 \mathrm{~kg}$ & $11.76 \mathrm{~kg}$ \\
Clothing & 1.40 meters & 1.79 meters & $0.43 \mathrm{~meters}$ \\
Rum/Spirits & 3.10 litres & 3.69 litres & 1.57 litres \\
Sugar & N/A & $3.36 \mathrm{~kg}$ & $1.24 \mathrm{~kg}$ \\
Codfish & $0.79 \mathrm{~kg}$ & $\mathrm{~N} / \mathrm{A}$ & $0.39 \mathrm{~kg}$ \\
Salt* & N/A & $30.74 \mathrm{~kg}$ & $14.00 \mathrm{~kg}$ \\
Tobacco & N/A & $6.99 \mathrm{~kg}$ & $1.12 \mathrm{~kg}$ \\
\hline
\end{tabular}

Note: for salt and tobacco, I could find no prices for Boston and my Philadelphia prices began in 1720. Hence, all items with the mention* mean that the average is only for 1720-1740. All observations for Pennsylvania are the average of 1720 to 1740 .

Overall, this chapter of my dissertation confirms that New France experienced no economic growth between 1688 and 1760. Its living standards were not substantially ahead of those observed in France at the bare bones level. At the respectable level, its advantage over France dissipates largely. Relative to the American colonies, the gap is much wider at the bare bones level and widens if I switch to the respectable basket. The difference observed between New France and the American colonies is roughly similar to the one observed with Latin America. This suggests that the colonial origins of divergence debate should consider the importance of divergence within North America. Finally, the differences observed for the living standards gap with the bare bones basket and the respectable basket suggest that New France's relative position is explained by poor productivity and that the respectable welfare ratios are probably the best figures to compare New France with other areas around the world. Moreover, I believe that my results are highly robust. The next chapter will outline numerous little points which lead me to believe that the case I have made overstates New France's relative position. However, since many historians may feel uncomfortable with my wage data, I believe that Chapter 4 will convince them that the estimates provided here can be used for future research. 


\subsection{Conclusion}

What can we conclude at this point? First and foremost, New France did not enjoy any sustained improvements in living standards throughout the period. This contrasts mightily with the results of Lindert and Williamson who found that New England enjoyed a positive rate of growth from the low levels it started from in 1675 (albeit at a very slow pace). ${ }^{268}$ Lindert and Williamson also found that living standards in the American South declined throughout the period. Given that we find stagnation in a region that has great geographical similarities with New England, this indicates that there are colonial origins to divergence within North America. It also indicates that there are different forms of divergence: New France stagnates, the south declines and New England and the Middle Colonies rise. Secondly, we can also see that the inhabitants of New France were more easily able to acquire the basic needs of life than their counterparts in France. However, moving beyond the bare bones basket of goods was costly and narrows the perceived gap between the two regions. This indicates that results showing that, at bare bones levels, the inhabitants of North America were better off than their European counterparts might not be capturing the full picture of divergence. It might be overstating the gap that some like Allen, Murphy and Schneider ${ }^{269}$ found. Indeed, moving from France to New France seems to have entailed paying a penalty in terms of foregoing non-essential consumption. Thirdly, we see other signs of divergence within North America. The gap between New France and the non-slave colonies of Pennsylvania and New England is wide (nearly 30\% with New England and more than $40 \%$ with Pennsylvania) at the bare bones level and wider at the respectable level. This places New France in the low zone of living standards with a gap that is relatively similar to the one observed between Latin America and the American colonies.

\footnotetext{
${ }^{268}$ Peter Lindert and Jeffrey Williamson. 2014. American Colonial Incomes, 1650-1774. Cambridge, MA : National Bureau of Economic Research, p.41.

${ }^{269}$ Robert Allen, Tommy Murphy and Eric Schneider. 2012. "The Colonial Origins of the Divergence in the Americas: A Labor Market Approach", Journal of Economic History, Vol. 72, No. 4, pp.863-94.
} 


\section{Part 4: ReAl Gross Domestic PRODUCT AND INCOME PER CAPITA}




\subsection{Wages are not sufficient!}

In the previous section, it was discovered that New France did not enjoy a substantial lead in living standards as measured through welfare ratios. Relative to France, the inhabitants of the colony did not enjoy a substantial advantage in terms of living standards. More importantly, New France's advantage over France disappears once we move to the welfare ratios that are more "respectable" (i.e. which include luxury goods and imported goods). Within North America, it was also a laggard. New England, which is considered to be poorest of the British colonies in North America, was appreciably richer. Once capital-intensive goods are considered, the inhabitants of New France are clearly the poorest. These results are strong, but they are by no means sufficient.

This is because there is data that suggests that living standards did increase during the era of French rule. My contention in this chapter will be to show that living standards did increase-very modestly - but probably because of a significant increase in the use of factors and that this growth was confined to eras of peace. In short, economic growth was driven by a more intense use of factors rather than a more efficient use of these factors. In fact, productivity declined while overall output increased. Since the welfare ratios are based on real wages and fixed assumptions about labor input, they represent a crude measure of the evolution of productivity, not of total production. Section 4.2. will review the evidence, both theoretical and empirical, that might limit the value of the results obtained previously with the use of welfare ratios. It will argue that the results I presented in Chapter 3 overstated modestly the level of living standards in New France and that the construction of a measure of GDP complements the welfare ratios based on wages. Section 4.3 will compute a new measurement of GDP by using a) better price data, b) more realistic output assumption and c) extending the measurements to the 1760 s. Section 4.3 will show that there was some growth up to 1740 but that it was reversed by 1760 - most likely as a result of war. Section 4.4 will highlight some puzzling observations about other measures of living standards.

\subsection{The limits of welfare ratios relevant to this work: weather, work year and family size}

It also ought to be mentioned at this point that the gaps in living standards found across regions are probably unduly favorable to New France. In essence, the case laid out in Chapter 4 is probably conservative. There are three reasons for this; a) different food requirements; b) family size and equivalence scales; c) length of work year. I argue that creating a measure of GDP will provide an important step in solving these problems by shifting to a measure of income.

The harsh climate of Quebec actually meant greater food requirements just to maintain a stable body mass. The relation between nutritional requirements and temperatures seems to be 
negative and linear whereby colder temperatures mean a greater energy requirement. ${ }^{270}$ The range of calorie requirements is quite large: from 3,100 in the desert at 33 degrees Celsius to 4,900 in arctic conditions (minus 34 degrees Celsius). ${ }^{271}$ Some have found smaller differences, but nonetheless, there are differences. ${ }^{272}$ The mechanism through which the temperature increases the energy requirements of the human metabolism is in part the greater weight carried by the heavier clothing in addition to the energy needed by the body to maintain body temperature. At higher altitudes, these are compounded by the difference in air pressure. ${ }^{273}$ In their attempt to construct estimates of the living standards of Natives in the Canadian north during the fur trade era, Ann Carlos and Frank Lewis assert that it is necessary to adjust the basket of comparison to include more calories for the natives given the climate - they assert that 3500 calories were needed rather 2500 calories for English workers. ${ }^{274}$ In Russia, Boris Mironov estimated that the average calories ingested stood at 2952 per day between 1865 and 1915 while the adult male had to consume 3204 calories per day. ${ }^{275}$ These two cases bear similarities with the St-Lawrence valley where New France was centered, especially in the Quebec City area. In fact, these numbers are well in line with those discussed in the previous section which means that the problem of estimation (2842 calories according to my estimate). If the French-Canadians consumed fewer calories than were required to maintain body mass, these differences could be seen in anthropometric data. The few existing studies of heights - as an anthropometric measure of living standards — suggest that the French Canadians were (albeit in the nineteenth century) quite short relative to other westerners. ${ }^{276}$ Consequently, the results presented above would clearly tip in the disfavour of New France were we able to construct differentiated baskets. However, the proper derivation of calorie consumption would require more archival research beyond that used for this dissertation.

The second limitation relates to family size. The families of New France were appreciably larger than they were in France. In general, the studies of the families of New France all tend to point towards a modal household size of 6 individuals. ${ }^{277}$ By comparison, Jean-Louis Flandrin

\footnotetext{
${ }^{270}$ Kaare Rodahl. 1954. "Nutritional requirements in cold climates." Journal of Nutrition, vol. 53, no. 4, pp. 575-588; Edward L. Gray, Frank Consolazio and Robert M. Kark. 1951. "Nutritional Requirements for Men at Work in Cold, Temperate and Hot Environments", Journal of Applied Physiology, Vol.4, No.4, pp.270-275.

${ }^{271}$ Peter J.H. Jones and Ian K.K. Lee. 1996. "Macronutrient Requirements for Work in Cold Environments" in eds. Bernadette M. Marriott and Sydne J. Carlson, Nutritional Needs in Cold and High-Altitude Environments: Applications for Military and Field Operations. Washington D.C.: Committee on Military Nutrition Research, Institute for Medicine, p.190.

${ }^{272} \mathrm{Ibid}, \mathrm{p} .191$.

${ }^{273}$ K.K. Srivastava and Ratan Kumar. 1992. "Human Nutrition in cold and high terrestrial altitudes", International Journal of Biometrology, Vol.36, No.1, pp.10-13.

${ }^{274}$ Ann Carlos and Frank Lewis. 2010. Commerce by a Frozen Sea: Native Americans and the European Fur Trade. Philadelphia, PA: University of Pennsylvania Press, p.172.

${ }^{275}$ Boris Mironov. 2012. The Standard of Living and Revolutions in Russia, 1700-1917. London: Routledge, p.277.

${ }^{276}$ John Cranfield and Kris Inwood. 2007. "The great transformation: a long-run perspective on physical well-being in Canada", Economics \& Human Biology, Vol.5, no. 2, pp.204-228.

${ }^{277}$ Louise Dechêne. 1992 [1974]. Habitants and Merchants in Seventeenth Century Montreal. Montreal and Kingston: McGill-Queen's University Press, p.238. As Dechêne points out in her work: "the modal structure was four children,
} 
reports that the average French household had 5.05 members ${ }^{278}$ This difference in family size could generate two separate problems. The first would imply that I am too liberal with my estimates. The second implies that I am too conservative. The first relates to the fact that a larger number of people may lead to an important error in measurement of household income. Although many children would be "partially raised,"279 they nonetheless contributed to the family income. Children were also appreciable contributors to family income. For example, they could be used as field hands. ${ }^{280}$ An early nineteenth century guide for emigrants to Canada noted that families around Québec City sent their children to gather small fruits and then sell them to city dwellers at a moderate price. ${ }^{281}$ The role of women is even more crucial. An intriguing feature of French Canada is the fact that women, rather than men, tended to be more literate whereas the reverse was true in the rest of North America. ${ }^{282}$ Few authors give attention to this topic, but it is often mentioned in passing that women were given piece-rates work to complement the family income. In fact, my own collection of data from the Séminaire yielded numerous piece-rates observations for wives of some workers. For example, 1 livre was paid for la façon d'une culotte (making pants) in 1723 while the blanchissement de quatre chemises (cleaning shirts) was remunerated at 4 sols per shirt. Overall, the economic contribution of women was considerable and even extended largely into skilled trade (since skilled labor was especially scarce). ${ }^{283}$ The larger families of New France could imply a greater income than was the case in France - an important fact given the

or six people per household". She added that "rough calculations based on later aggregate censuses, indicate that that the number of children per family remained more or less stable until the beginning of the eighteenth century". For the eighteenth century, the data provided by George Langlois confirms that Dechêne's family structure did not evolve considerably. Collecting mortality, nuptiality and baptism statistics from the different parishes of Quebec, Langlois managed to recreate our modern estimates of mortality, nuptiality and fertility in the colony up to the formation of the Canadian Confederation. His figures suggest that for each marriage being sanctified in the colony between 1700 and 1760, there were 5.78 births. Georges Langlois. 1935. Histoire de la Population Canadienne-Française. Montréal : Éditions Albert Lévesque, pp.255-262. Marilyn Gentil of the University of Montreal has compiled infant mortality quotient for the eighteenth century which allow us to correct this figure. Throughout the eighteenth century up to 1760 (but not thereafter), the infant mortality rate (below one year of age) increases steadily from $15 \%$ of all births to roughly $30 \%$ of all births. This brings the figure much closer to four children left on average per family. Adding mortality of other children who were above the one-year old threshold, the figure of four children per set of parents seems to hold in the eighteenth century. Marilyn Gentil. 2009. Les Niveaux et les Facteurs Déterminants de la Mortalité Infantile en Nouvelle-France et au début du Régime Anglais (1621-1779). PhD thesis, department of demography, Université de Montréal, p.145.

278 Jean-Louis Flandrin. 1979. Family in Former Times: Kinship, Household and Sexuality. Cambridge: Cambridge University Press, p. 55.

279 The expression comes from Jane Humphries. 2013. "The lure of aggregates and the pitfalls of the patriarchal perspective: a critique of the high wage economy interpretation of the British industrial revolution”, Economic History Review, Vol. 66, No.3, p.705.

${ }^{280}$ André Lachance. 2000. Vivre, aimer et mourir en Nouvelle-France : La vie quotidienne aux XVIIe et XVIIIe siècles. Montréal : Éditions Libre Expression, pp.60-66.

${ }^{281}$ No author specified. 1820. The Emigrant's guide to the British settlements in Upper Canada and the United States of America. London: T. Keys, p.90.

${ }^{282}$ Gillian Hamilton. 1999. "Property rights and transaction costs in marriage: Evidence from prenuptial contracts", Journal of Economic History, Vol.59, no.1, pp.99.

${ }^{283}$ Suzanne Gousse. 2009. Les couturières en Nouvelle-France : leur contribution socioéconomique à une société coloniale d'Ancien Régime. MA thesis, department of history, Université de Montréal, 
relative abundance of land to labor (there was very little offsetting effect of having large families). However, this first issue with family size might cut the other way as well. As Peter Lindert and Jeffrey Williamson showed, large family sizes in the United States meant lower rates of labor force participation than elsewhere. Thus, this point might cut both ways.

However, there is one factor related to family size that would overstate the living standards of French Canadians since the commonly used approach to welfare ratios might understate the costs for a household. To avoid any needless qualms, I opted to use the common approach of welfare ratios which is to assume the three adult equivalents inside a household which Allen used (discussed in section 3.2). The concept of adult equivalents refers to the attempt to render households comparable regardless of size and composition. This is meant to reflect that children and women have different nutritional requirements than adult males and that households benefit from economies of scale for certain types of goods. ${ }^{284}$ In a recent working paper, Allen points out that "on the assumption that a family consisted of a man, a woman, and two children, it was assumed that a family corresponded to three adult male equivalents". ${ }^{285}$ In essence, very few individuals disagree with the idea that equivalence scales are needed. The problem is "which scale to use." The conversion into adult equivalents is subject to debate. Three approaches exist. The first uses the square root of the number of individuals. The second attributes the full weight of the first adult, half the weight of the second adult and $30 \%$ for each child. This approach is commonly used by the OECD, ${ }^{286}$ Statistics Canada ${ }^{287}$ and numerous government agencies in Canada. ${ }^{288}$ The third approach is the one used by the National Academy of Sciences in the United States which proposed to use an exponent ranging between 0.65 and 0.75 to household size but only after having multiplied the number of children by $0.7 .^{289}$ As a result, a family of four can have either 2 adult equivalents (square root), 2.1 adult equivalents (OECD and Statistics Canada approach) or 2.36 adult equivalent (NAS approach). The differences relative to the square roots approach are $5 \%$ and $18 \%$. If we move to a family of 6 persons, the differences increase to $10.22 \%$ and $34.72 \%$. For the purposes of my dissertation, this would not be a problem if family sizes were identical. The issue is that they are different. New France families are appreciably larger. The selection of one method over another would have important effects on the cost of the living basket, with the NAS approach showing the costliest basket. Using a method relatively close to that of the OECD (although not exactly that measure), Eric Schneider found that the relatively small size of families in England

\footnotetext{
${ }^{284}$ The « classic » source on this topic is Angus Deaton and John Muellbauer. 1980 [2009]. Economics and Consumer Behavior. Cambridge: Cambridge University Press.

${ }^{285}$ Robert Allen. 2013. Poverty Lines in History, Theory, and Current International Practice. Discussion Paper Series, Department of Economics, Oxford University, p.2

${ }^{286}$ Organization for Economic Cooperation and Development. Undated. What Are Equivalence Scales? Paris: OECD.

${ }^{287}$ Jamie Carson. 2002. Family Spending Power. Ottawa: Statistics Canada.

${ }^{288}$ Guy Fréchet, Pierre Lanctôt, Alexandre Morin and Frédéric Savard. 2010. Equivalence Scales: An Empirical Validation. Québec : Centre d'étude sur la pauvreté et l'exclusion.

${ }^{289}$ Constance Citron and Robert T. Michael (eds). 1995. Measuring Poverty: A New Approach. Washington D.C. : National Academy Press.
} 
led Allen to underestimate the level of real wages. ${ }^{290}$ In a more recent paper, Allen alongside Schneider and Murphy pointed out that extending Schneider's analysis to Latin America where "family sizes were likely larger (...) than in England and British North America" would amplify the wage gap between the two regions. ${ }^{291}$ The same would also apply for New France with its historically large families. The problem would grow even larger if one were to shift to a different equivalence system like that of the NAS. As a result, the case made in Chapter 3 would understate the costs of the basket in New France. To see how important the difference is, one can use the family sizes for France and Canada reported in Flandrin (5.05 persons per household circa 1700) ${ }^{292}$ and the Census recompilations for Canada (5.99 persons per household in 1688). ${ }^{293}$ For the year 1688, Canadians had welfare ratios $32 \%$ above those of Parisians. However, with the square root method of adjusting for family size, the advantage shrinks to $21 \%$. With the OECD method, it shrinks to $18 \%$ and with the NAS method, it stands at $22 \%$. This shows how sensitive assumptions about the basket are.

The elements related to the food requirement differences and family size are hard to solve. However, their existence confirms that the case I made above in Chapter 3 made Canada artificially better off than it really was. Solving these issues would widen the gap in living standards New France exhibited and its divergence within North America would be magnified. However, the difference of a few calories and the adjustments for family would not change the trend line nor would it change the overall conclusion.

The third remaining problem is also one that favors New France (if resolved, the gap would widen). This relates to the work year assumption of 250 days that underlies the welfare ratios. By sheer virtue of the cold climate of Canada, the length of the work year was highly limited. The data from the port of Quebec City between 1814 and 1861 is quite suggestive in that regard. The length of the open harbour season was dependent on the time it took for the winter ice to thaw. During that period, the average opening season stood at 226 days. ${ }^{294}$ This would stand as a liberal estimate since, according to the Atlas Agroclimatique du Québec, the average length of the growing season in Quebec for the regions that correspond with those that were settled by 1760

\footnotetext{
${ }^{290}$ Eric Schneider. 2013. "Real Wages and the Family: Adjusting Real Wages to Changing Demography in PreModern England", Explorations in Economic History, Vol.50, no.1, pp.99-115

${ }^{291}$ Robert Allen, Tommy Murphy and Eric Schneider. 2015. "Una de cal y otra de arena: building comparable real wages in a global perspective." Revista de Historia Económica/Journal of Iberian and Latin American Economic History, Vol.33, no.1, p.69.

292 Jean-Louis Flandrin. 1979. Family in Former Times: Kinship, Household and Sexuality. Cambridge : Cambridge University Press, p. 55.

${ }^{293}$ Public Archives of Canada. 1876. Volume IV of the 1871 Census of Canada. Ottawa: Department of Agriculture, p.21.

${ }^{294}$ Parlement de la Province du Canada. 1862. Documents de la Session : Première Session du Septième Parlement, Vol. XX. Québec : Hunter, Rose et Lemieux, unpaginated.
} 
varies from 171 days to 215 days. $^{295}$ This data was the average between 1971 and 2000 and it was probably higher since that period was not exceptionally warm ${ }^{296}$ Thomas Wien reported that, in the eighteenth century when temperatures were colder, this was clearly a shorter period that it is today. ${ }^{297}$ In Wien's eyes, the season in which one could work his farm only lasted 150 days - and sometimes even less. ${ }^{298}$ According to USDA data, the usual planting and harvesting dates for corn and potatoes for Massachusetts suggest growing seasons of 181 days and 174 days which is not very far from the estimates for New France. ${ }^{299}$

Although this is not much different from New England and Atlantic Canada, it is quite different than it was in France. Merely for the Alsace region, Charles Hanauer reports that the summer season lasted from February $22^{\text {nd }}$ to October $16^{\text {th }}$ which represents 236 days. ${ }^{300}$ Moreover, Hanauer offered numerous wage rates in winters, suggesting that workers had more time available to work. This factor would play in the disfavor of comparisons between France and New France since French workers could work longer periods for a higher income while the inhabitants of New France could not work similarly long periods. When Jeffrey Williamson and Peter Lindert enacted their comparisons of welfare ratios in Britain and the United States, their main point of hesitation centered around what was the proper number of days. In the face of limited reliable evidence, they opted for 313 days per year but admitted the limitations of this method. ${ }^{301}$ To be fair, this criticism is very hard to solve since work years were not reported. Yet, it remains significant. In his book on the population of New France, Alan Greer pointed out that the average worker "with earnings coming in during only part of the year, would be hard-pressed to maintain himself at the even most basic level in the long run." 302 The difference in the work year between France and New France implies that the slight advantages discovered in the previous section would play against New France's advantage over France. However, the length of the harvest season might not be a proper indicator of the length of the work year. Male farm workers could complement their income by providing timber and firewood for urban markets and providing some work while in the city. ${ }^{303}$

\footnotetext{
${ }^{295} \mathrm{http}: / /$ www.agrometeo.org/atlas/help

${ }^{296}$ K. Briffa, P.D. Jones and F.H. Schweingruber. 1994. "Summer temperatures across northern North America: regional reconstructions from 1760 using tree-ring densities." Journal of geophysical research, vol.99, no. D12, pp.25835-25844.

${ }^{297}$ Thomas Wien. 1990. "Les travaux pressants : calendrier agricole, assolement et productivité au Canada au XVIIIe siècle" Revue d'histoire de l'Amérique française, vol.43, no.4, pp.545.

${ }^{298}$ Ibid, p.556.

${ }^{299}$ United States Deparment of Agriculture. 1997. Usual Planting and Harvesting Dates for U.S. Field Crops. Washington D.C.: National Agricultural Statistics Service at the USDA, p.39.

${ }^{300}$ Charles Auguste Hanauer. 1878. Études économiques sur l'Alsace ancienne et moderne (denrées et salaires). Paris : Société industrielle de Mulhouse, p.414.

${ }^{301}$ Peter Lindert and Jeffrey Williamson. 2014. American Colonial Incomes, 1650-1774. Cambridge, MA: National Bureau of Economic Research.

302 Alan Greer. 1997. The People of New France. Toronto: University of Toronto Press, p.56.

${ }^{303}$ Richard Harris. 1966 [1984]. The Seigneurial System in Early Canada. Montréal: McGill-Queen's University, p.114. Later in this book, Harris (p.162) documents how income could be complemented through the provision of wood products to the urban markets.
} 
Donald Paterson and William Marr also pointed out how important the timber trade would have been in the early days of land clearing for any new farm household. The main advantage from these operations as Paterson and Marr pointed out was that "cutting timber was generally carried out at the time of the year when no major farming effort was necessary." ${ }^{304}$ Eventually, the sale of the timber products - which were a by-product of land clearing-would serve to finance consumption in the early years of settlement. Moreover, the banks of the St-Lawrence river seem to have been used year-round for shipbuilding (albeit for ships whose tonnage rarely exceeded 100 tons), meaning that there was appreciable wintertime employment in spite of the harsh temperature. ${ }^{305}$ And quite obviously, there was the fur trade in which many were involved - in spite of interdictions by the colonial administration. In short, income could have been constrained by an inability to supply a large quantity of labor or there could have been no such problem. We cannot know what the "proper" work year for France or New France was. The problem is not only spatial in nature but temporal as well. Any time series of welfare ratios would be disrupted by a structural break in working hours. In short, the issue relates to whether or not we can safely make inferences about incomes on the basis of wages. Economic historians like Paul Bairoch tend to believe that we can use wages as an indicator of Gross Domestic Product (GNP). ${ }^{306}$ However, as Broadberry and al. have argued, real wages can differ substantially from income for some periods of time if there were large changes in labour supply. They show that the important change in labour hours meant an increase in GDP per head which could not be seen in the wage rates. ${ }^{307}$ At any point in time, if there was a momentous change in terms of labour hours supplied, the comparisons between regions would be altered significantly.

These problems are not purely theoretical, there is considerable evidence that they may matter. One example is derived from the work of Sylvie Dépatie. ${ }^{308}$ In her doctoral thesis, Dépatie collected 86 probate records for the Île-Jésus estate — an island north of Montreal which was owned by the Séminaire de Québec — between 1721 and 1756 (she extended to 1775 in her study, but for our purposes, I will stop at the last years she has that correspond with French rule). The net worth of households adjusted for inflation (using the index derived earlier in this thesis) show an appreciable increase during that period (see Figure 4.1). Obviously, the small size of her sample limits how much we can draw from her data. However, her data supports very well the GDP estimate provided by Morris Altman which suggests a 20\% increase in per capita income between

\footnotetext{
${ }^{304}$ William Marr and Donald Paterson. 1980. Canada: An Economic History. Toronto: Gage Publishing, p.65.

305 Pierre Dufour. 1981. "La construction navale à Québec, 1760-1825: sources inexplorées et nouvelles perspectives de recherches." Revue d'histoire de l'Amérique française, vol. 35, no. 2, pp. 231-251.

306 Paul Bairoch. 1989. "Wages as an Indicator of Gross National Product" in eds. Peter Scholliers, Real Wages in 19th and $20^{\text {th }}$ century Europe: Historical and Comparative Perspectives. New York: Berg Publishing, pp.51-60.

${ }^{307}$ Stephen Broadberry, Bruce M.S. Campbell, Alexander Klein, Mark Overton and Bas van Leeuwen. 2015. British Economic Growth, 1270-1870. Cambridge: Cambridge University Press, pp.257-265.

${ }^{308}$ Sylvie Dépatie. 1988. L'évolution d'une société rurale : l'T̂le Jésus au XVIIIème siècle. Montréal, PhD Thesis, Department of History, McGill University
} 
1695 and $1739 .{ }^{309}$ It also supports Alice Jean Lunn's ${ }^{310}$ seminal 1942 thesis which argued that colony experienced appreciable economic development up to 1760. This contrasts against the portrait drawn up in the previous section with welfare ratios where growth was nearly nonexistent - hence some could be skeptical with reason (although I disagree).

Figure 4.1. Real net worth of estates at death in Île Jésus, 1721-1756 (livres of 1720-1724)

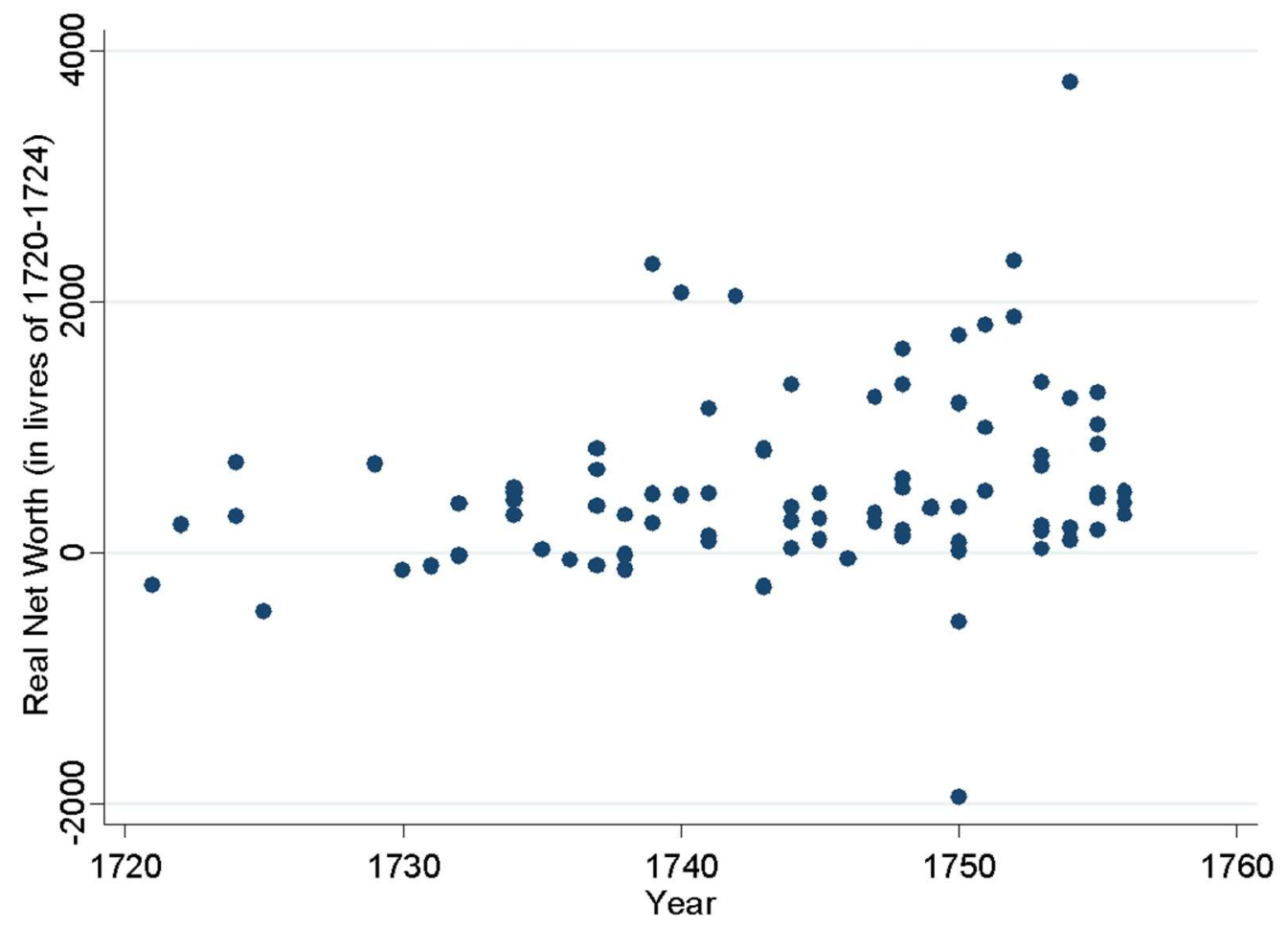

The solution to these problems is theoretically simple: measure output. Overall output would capture the increase in production per capita regardless of whether or not it was caused by differences in work days. The issue of different family size will be lessened since we simply measure total output expressed on a per capita basis. Hopefully, there is already one GDP series existing out there upon which we can greatly improve given the wealth of new data collected.

\subsection{A new GDP series for New France}

The only available estimates stem from the work of Morris Altman who attempted to settle an ongoing debate on the history of French Canada during the colonial era. According to Altman, from whom I have borrowed these labels, there are two camps in the historiography of New France:

\footnotetext{
${ }^{309}$ Morris Altman. 1988. "Economic Growth, Economic Structure and Real Gross Domestic Product in Early Canada, 1695-1739" William and Mary Quarterly, Vol.45, p.684-711.

310 Alice Jean Lunn. 1986 (1942). Développement économique de la Nouvelle-France, 1713-1760. Montréal: Presses de l’Université de Montréal.
} 
the "pessimists" and "optimists." "311 Both camps marshalled empirical evidence of numerous forms, to no avail. Since his work, the literature has evolved towards more local studies rather than attempting to provide new data.

Altman's methodology was fairly simple: use existing censuses (there were many) which report the physical quantities of goods produced, combine them with estimates of goods exported like furs and multiply them all by a fixed price - that of 1749. This method, although it may strike some as unconventional, is nothing more than a volume index. By converting quantities of goods and services which were measured in physical quantities like minots (1.107 bushel) or pots (1.9 liters) into monetary values, Altman was creating a uniform measure of the volume of production. In short, the use of a fixed year in terms of prices was not seen as problematic since it was a manner through which production could be measured as a single form of volume. Obviously, researchers would prefer a series of continuous prices to measure the true value of production more precisely. ${ }^{312}$ However, given the technological constraints of the time at which Altman wrote his article, the effort was a colossal undertaking. His results yielded what can be seen in Figure 4.2 below.

\footnotetext{
${ }^{311}$ Morris Altman. 1988. "Economic Growth, Economic Structure and Real Gross Domestic Product in Early Canada, 1695-1739" William and Mary Quarterly, Vol.45, p.684.

312 This would be especially useful in order to link with the holy grail of Canadian GDP reconstructions produced by M.C. Urquhart. 1993. Gross National Product, Canada, 1870-1926: The Derivation of the Estimates. Kingston \& Montreal, London, Buffalo: McGill-Queen's University Press.
} 
Figure 4.2. Altman estimates of per capita GDP in New France (1749 livres)

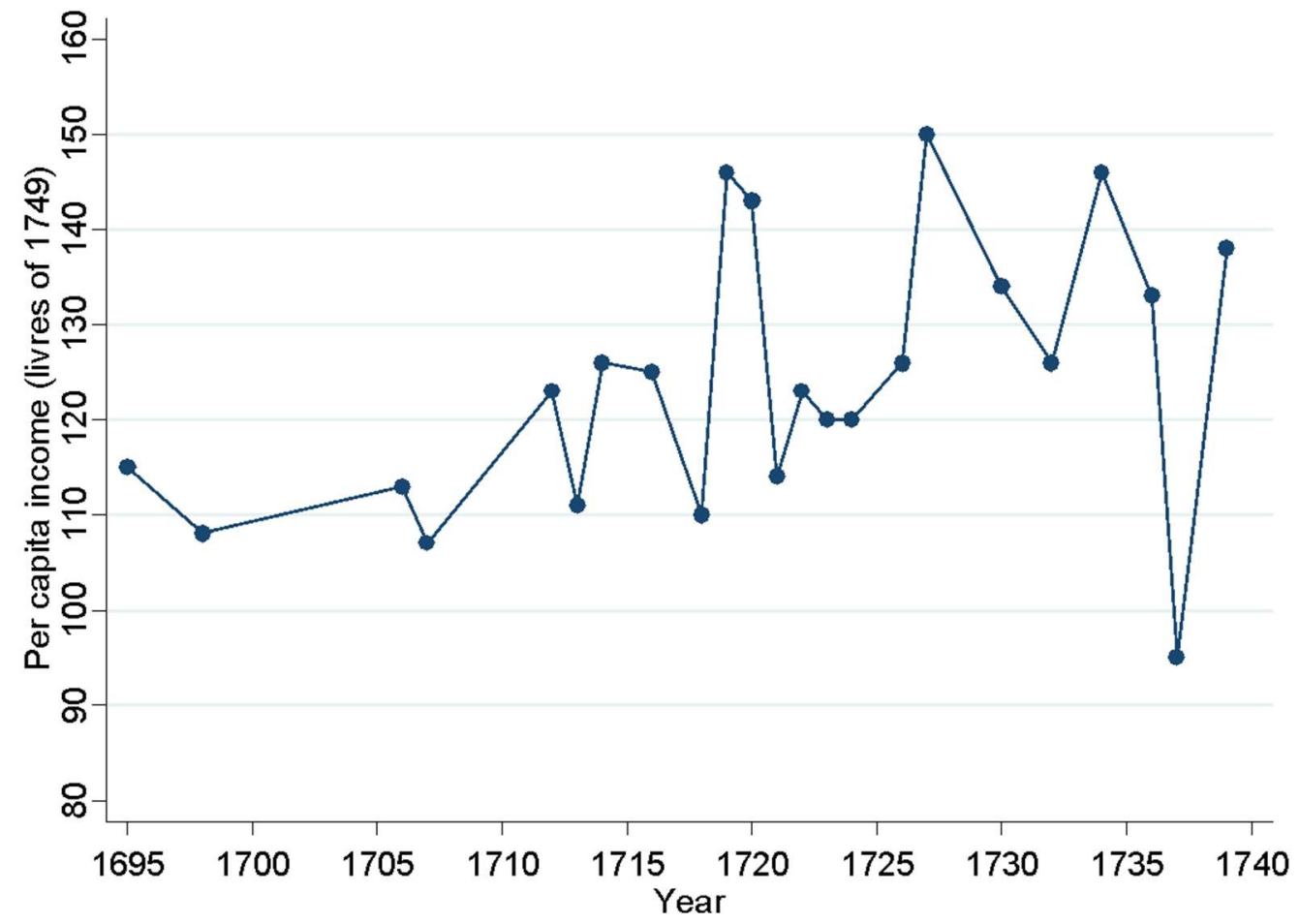

Between 1695 and 1739, the annual compounded rate of growth of real per capita income stood at $0.42 \%$. This initial estimate was not beyond the range found by authors who produced conjectural estimates for Colonial America. ${ }^{313}$ It is on par with the general rate of economic growth of $0.4 \%$ per annum observed by Alice Hanson Jones. ${ }^{314}$ It is also in the range of $0.3 \%$ to $0.6 \%$ estimated by McCusker and Menard for the period between 1700 and $1774 .{ }^{315}$ However, it is above

313 Gloria Main and Jackson Main. 1988. "Economic Growth and the Standard of Living in Southern New England, 1640-1774", Journal of Economic History, Vol.48, no.01, pp.27-46.

314 Alice Hanson Jones. 1980. Wealth of a nation to be: The American colonies on the eve of the Revolution. New York: Columbia University Press.

315 John McCusker and Russell Menard. 1985. The Economy of British America, 1607-1789. Chapel Hill, NC: University of North Carolina Press, pp.51-70. 
the near $0 \%$ growth rate found by Mancall and Weiss for the entire thirteen colonies. ${ }^{316}$ It stands closer, but higher to rates of growth found for the Middle colonies by Rosenbloom and Weiss. ${ }^{317}$

However, Altman's results are rarely used. In his 1998 book on New World economies, Marc Egnal spends his entire section on French Canada to document its supposedly strong rate of economic growth using sugar consumption, the purchasing power of grains sold, prices of cloth, imports and exports. He only spends one line on Altman's estimates in spite of the fact that they would have supported the case he elaborated both in that book and in an earlier one. ${ }^{318}$ He relegates Altman's growth estimates to an endnote. In discussions with historians of Quebec, it was often mentioned that Altman's measures were found to be unconvincing for numerous reasons-fixed assumptions about seed requirements, fixed assumptions about pastoral production and the fixed prices for 1749. Few have written on the topic. The exception is Catherine Desbarats. Desbarats asserted that "weighting all quantities by the price of a single year is a costly short cut." 319 Although his approach, as underlined above, is common for economic historians ${ }^{320}$ and is a common method in national accounting, her criticisms seem to have landed within the academic community given the low level of attention given to Altman's estimates. At the very least, her criticisms seem to be shared among the historians. However, I do not consider her criticisms to be relevant to assessing productivity trends. Her criticism amounts to asking for a nominal GDP series to be constructed. Nominal GDP, unlike the real GDP method expressed as a volume index, confounds changes in quantities with changes in prices. Assessing productivity requires attention only on quantities, not prices. Nonetheless, the criticism has some value if our goal is to compare incomes across countries. The advantage of creating a nominal GDP series would be to able to deflate by the welfare ratios derived above (see more below).

\footnotetext{
316 Peter Mancall and Thomas Weiss. 1999. "Was Economic Growth Likely in Colonial British North America", Journal of Economic History, Vol.59, no.1, pp.17-40. This paper is an exception in the field in terms of overall growth in the colonies. In his review of the estimates of early American GDP, John McCusker asserted in an endnote that the Mancall and Weiss paper was "hard to take seriously", was "patently and self-servingly tautological in its estimating procedures" and displayed "culpable ignorance of much of the existing work on the subject". John McCusker. 2000. "Estimating Early American Gross Domestic Product", Historical Methods: A Journal of Quantitative and Interdisciplinary History, Vol. 33, no.3, p. 160. However, in spite of the vitriolic comments by McCusker with regard to Mancall and Weiss, the paper does offer a comprehensive understanding of the estimates of incomes in the colonial era.

${ }^{317}$ Joshua Rosenbloom and Thomas Weiss. 2014. "Economic growth in the Mid-Atlantic region: conjectural estimates for 1720 to 1800", Explorations in Economic History, Vol.51, no.1, p. 53.

${ }^{318}$ Marc Egnal. 1998. New World Economies: The Growth of the Thirteen Colonies and Early Canada. Oxford: Oxford University Press; Marc Egnal. 1996. Divergent Paths: How Culture and Institutions have shaped North American Growth. Oxford: Oxford University Press.

${ }^{319}$ Catherine Desbarats. 1992. "Agriculture within the Seigneurial Régime of Eighteenth Century Canada: Some Thoughts on the Recent Literature", Canadian Historical Review, Vol.73, no.1, p.10.

${ }^{320}$ Nicholas Crafts, and Knick Harley. 1992. "Output growth and the British industrial revolution: a restatement of the Crafts-Harley view.” The Economic History Review 45, no. 4, pp. 703-730.
} 
In Altman's work, there are also some minor shortcomings which might irk economists as well. Any criticisms to be dressed against Altman regard whether or not the year he chose, 1749, was a representative year. This is because the selection of that year might lead to the creation of the Gerschenkron effect. This effect refers to when weighing schemes might have biases that creep up over time. Initially, Gerschenkron noticed it for the Soviet Republics when the physical quantities produced were multiplied by prices from the early years of the Russian revolution. ${ }^{321}$ As time passed, the reference year for volume became less characteristic of the volume of production over time. In this case, it was the starting year that was problematic to estimating the endpoint of economic growth. In the case of Altman, it might be the reverse whereby Altman's weights would be less representative of the early period. As Altman has used the year 1749 in terms of reference point for all years prior to 1739 , it is possible that it is not fully reflective. Another reasonable qualm to be had with Altman's estimates stem from his choice of a starting date. Altman began his statistical series in 1695 - a year when Canada was suffering through a long war. In fact, the city of Quebec had been besieged a few years before and many farms had been destroyed. Hence, the starting point of 1695 was probably a low point thanks to war-induced supply shocks. With the exception of a brief interlude from 1697 to 1701, Canada was basically at war at all times from 1688 to 1713 . The period from 1713 to 1740 was one of peace. Hence, it might be problematic to have a conjectural estimate begin in a war year and end in a peace year. This is why this paper believes that an important first step is to find a year in which to estimate the GDP in a peace year. The year available is 1688 , just at the onset of the Nine Years War.

The last problem with Altman's method is that thanks to its conception as a volume index, it is meant for analysis over time rather than over space. It is impossible to use Altman's index to compare income levels reliably since prices are fixed to 1749 . Using the nominal value of output rather than a volume index would permit a comparison with other colonies. Consequently, there is a need to recompute the Altman GDP series - something which is not too hard given the wealth of detail he provides. This is not too hard a task given the wealth of data collected above in terms of prices and wages. This wealth of data will allow us to overcome this problem which plagued Altman's paper.

In essence, the approach I will use will produce two series for GDP. The first will estimate quantities in each year multiplying them by current prices to obtain nominal GDP and then deflating it by the price index construction in Chapter 3 of this dissertation. That estimate is meant to answer Desbarats' criticisms regarding Altman's initial computations. The second will be a replication of Altman's quantity index (quantities by prices for 1739) with a different base year than he used. Some modifications to output estimates will be enacted in order to make them more

\footnotetext{
${ }^{321}$ Alexander Gerschenkron. 1947. “The Soviet Indices of Industrial Production”, Review of Economics and Statistics, Vol.29, No.4, pp.217-226.
} 
realistic. Finally, we can add an estimate for circa 1762 - but this estimate is very tentative and should be considered with prudence.

\section{Grains}

I have preserved the assumptions made by Altman to measure net wheat and peas output. This method consisted in assuming that $75 \%$ of cultivated land was allocated to growing wheat. Seed requirements are retrenched by assuming that two minots were sown per arpent which produces the estimate of net wheat output. The estimate for peas is made by taking only $1 / 8^{\text {th }}$ of all peas - the rest was used as seed or to feed to animals. As for oats and barley, which were minor crops, they have been considered merely as inputs for pastoral production as Altman did. ${ }^{322}$

\section{Tobacco, Hemp and Flax}

Unlike Altman, we have excluded tobacco, hemp and flax. Tobacco was not recorded in the censuses before 1721 and assuming that the same quantity was always produced in all preceding years is problematic. This is because tobacco tended to be imported in the early years. In the process of collecting prices in the archives of the Séminaire de Québec, it was noticed that tobacco prices were often recorded as "du pays" or "noir" (domestically grown or black). The mention of "du pays" is very rare prior to the 1710 s and it becomes more and more present in the 1720 s onwards. As a result, it was probably not an important crop - at least not as important as Altman gives it weight - prior to the census of 1721 when it was likely deemed a sufficiently worthwhile crop to collect census information about it. As for hemp and flax, the extent of their production is inconsequential and they remain stable per capita in Altman's work as he assigned them a fixed value throughout the era.

\section{Wool and Dairy}

With regard to production of wool, I have adjusted the assumptions made by Altman. Altman merely multiplied the quantity of sheep reported by 1.3 pounds and then by the price of wool. The $1851 / 52$ census suggests 2.2 pounds per sheep, which is larger than that proposed by Altman. ${ }^{323}$ However, switching from 1.3 pounds to 2.2 pounds does not change the overall results. With regard to dairy output, Altman introduced 44 pounds of butter equivalents per cow. Altman actually used different versions of this calculation in different papers with a butter equivalent of 52 pounds of butter equivalent (albeit for 1851). These are strangely low. In comparison, McInnis and Lewis

\footnotetext{
${ }^{322}$ Morris Altman. 1988. "Economic Growth, Economic Structure and Real Gross Domestic Product in Early Canada, 1695-1739" William and Mary Quarterly, Vol.45, p.698.

${ }^{323}$ Public Archives of Canada. 1873. Volume IV of the 1871 Census of Canada. Ottawa: Department of Agriculture, p.221.
} 
attributed 92 pounds per cow. ${ }^{324}$ This is because estimates over the colony differ. An 1824 survey of the Valcartier settlement outside Quebec City reported in the journals of the Legislative Assembly gave an estimate of 60.4 pounds of butter per cow - an estimate which did not include milk consumed by peasants. ${ }^{325}$ According to a visitor's journals, a cow could produce 10 to 12 quarts of milk per week in $1832 .{ }^{326}$ This is equivalent to 21.5 and 25.8 pounds. We are considerably beyond the estimates proposed by Altman and much closer to those proposed by McInnis and Lewis. Hence, I will use their proposed production figures. However, using fixed figures has the downside of ruling out any productivity improvements - an issue that will also affect the estimates of slaughtered animals below.

\section{Slaughtered Animals}

With regard to the value of slaughtered animals, I opted to modify slightly Altman's method. The estimation of output is derived using a methodology similar to that of Rothenberg ${ }^{327}$ on the farmers of Massachusetts in the early nineteenth century. Rothenberg's data on animal weights in Massachusetts in the early nineteenth century (circa 1800) suggests that after slaughter, a cow weighs 221.3 pounds, an ox weighs 402.4 pounds and a steer weighs 189.9 pounds (in dressed weight which accounts for losses). Secondly, Rothenberg pointed out that the percentage of ox, cows and steers that were slaughtered differed significantly (the rates of slaughter stood respectively at $20 \%, 12 \%$ and $50 \%$ ). Thanks to Rothenberg's propositions, we can isolate the total quantity of meat produced. In combination with herd composition data drawn from Dépatie, ${ }^{328}$ we can divide "cattle" according to each animal group reported in probate records. For swine production, there were no prices for pork up until the $1810 \mathrm{~s}$ which limits our capacity to approximate the value of production. However, Horovitz' $\mathrm{s}^{329}$ work suggests that pork and beef were very close in terms of prices and can thus be substituted as equivalent. Moreover, the relative price of pork to beef in Horovitz's work does not fluctuate greatly suggesting that at worst, this method might get the level wrong, but the trend right. The slaughter rate and the dressed weight are drawn from Rothenberg. For poultry, the method of estimating egg and meat production is

\footnotetext{
${ }^{324}$ Frank D. Lewis and Marvin McInnis. 1984. “Agricultural Output and Efficiency in Lower Canada, 1851”, Research in Economic History, Vol.9, p.74.

${ }^{325}$ House of Assembly of Lower Canada. 1824. Appendix to the Journal of the House of Assembly of Lower Canada. Québec: House of Assembly of Lower Canada, Appendix R (non-paginated).

${ }^{326}$ No author specified. 1833. Present state of the Canadas: containing practical and statistical infortmation respecting the climate, soil, produce, agriculture, trade, currency, banking \&c., of Upper and Lower Canada, useful for the emigrant, merchant and Tourist. London: G.Herbert Publishing, p. 91.

${ }^{327}$ Winifred Rothenberg. 1979. "A Price Index for Rural Massachusetts, 1750-1855” Journal of Economic History, Vol.39, No.4, pp.995.

${ }^{328}$ Sylvie Dépatie. 1988. L'évolution d'une société rurale : l'Île Jésus au XVIIIème siècle. Montréal, PhD Thesis, Department of History, McGill University

${ }^{329}$ William Bela Horovitz. 1967. An Index of Retail Market Prices at Montreal, 1843-1867. Montreal, MA Thesis, Department of Economics, McGill University.
} 
arrived at differently. The censuses do not include mention of chickens. Relying on probate records by Dépatie from the late eighteenth century and early nineteenth century where herds include chickens allows us to arrive at a reasonable estimate relative to the number of horses -5.25 chickens per horse. Altman's estimate of 12 chickens and 1 cock per farm drawn from Séguin ${ }^{330}$ is thus probably a very liberal estimate of the true number of chickens. Most of the literature proposes smaller herds of poultry. However, I kept the slaughter rate of $66.67 \%$ (8 out of 12) used by Altman. However, in the process of collecting prices, I managed to collect numerous prices for chickens. This series moves akin to the eggs series in my basket above. Missing values (there were few) were created according to these movements. Afterwards, an arbitrary production of 200 eggs is estimated, something which Altman does not include.

\section{Land Clearing and Construction}

With regard to the value of land improvement, my wage rates suggest that the average nominal wage rate between 1688 and 1740 was 1.51 livres per day for the unskilled worker, much more than Altman's estimate. The observed wage rates the opportunity cost of land improvements: a day not spent improving the land he received from his landlord was a day at which a peasant could earn 1.51 livres. The wage rate is then multiplied by the product of the number of days needed to clear an arpent to the pace of land clearing. As for barn construction, I took the estimate of the cost of a barn provided by Altman and indexed it to the general price index and followed his specification.

\section{Firewood}

As for firewood, Altman kept it constant at 13 livres per capita while I assume that a household of six needed 20 cords of wood (of the French measuring system which was smaller than the British cord in terms of dimension) as was discussed earlier in this thesis. This was the bare minimum to survive the winters of Canada while also being able to meet cooking requirements. Obviously, this is not a perfect measure since we are using consumption rather than output produced. Moreover, it remains fixed throughout the period which is a very big assumption. However, it is the best we can do.

\section{Non-Agricultural Sector}

With regard to non-agricultural output, I have followed a similar specification to Altman who relied on the share of the urban population, but unlike him I did not keep this figure constant at $23 \%$ as it is very clear from other research that Canada grew increasingly rural during the era of

\footnotetext{
${ }^{330}$ Maurice Séguin. 1947. "Le régime seigneurial au pays de Québec, 1760-1854 (1er article)." Revue d’histoire de l'Amérique française, Vol.1, No.3, pp.382-402.
} 
French rule. ${ }^{331}$ Hence, the non-agricultural population is presumed to be equal to the urban population. I have assumed that the urban population's output was mostly created by adult skilled workers. I have assumed that households provided 313 days of male-adult-equivalent work per year in order to get the approximation of their output contribution to the economy. This is how I will measure the contribution of urban households. However, I excluded estimates of shipbuilding and timber exports like those of Altman. I assume that this has been captured in the estimate of non-agricultural production described above. Although this is not ideal, it is better than attempting to include them at the risk of double-counting. Most of the workers involved in shipbuilding were urban workers or lived very close to urban areas. Hence, they will have been counted in our previous estimate of the non-agricultural sector. As for the timber trade, this would also have been accounted for in the assumption of 20 cords per household of six. As Harris noted, rural households probably produced more wood than they needed and sold significant quantities in the cities to merchants and urban dwellers. ${ }^{332}$ A large part of the timber trade would have been captured through the measure mentioned above. This is especially true in the case of timber. Timber exports are only reported from 1727 onwards, but it was exported on occasions before. Hence, it is likely that including timber exports from 1727 would bias the movement of output upwards after 1727. Finally, this method of counting the non-agricultural sector is efficient in the sense that it avoids the issue of government spending from foreign transfers to be included in GDP. Since most of these transfers served to finance military installations, barricades and the fortification of Quebec City, these would appear in the city as demand for construction workers thus making the 313 days of adult-male equivalent of work per household realistic.

\section{Fur Exports}

The largest non-agricultural sector left is that of the fur trade. In his work, Altman provided some estimations of the value of exports, but I opted for his original source which was Alice Jean Lunn $^{333}$ who provided value on an annual basis from 1718 onwards (we can also find graphical illustration of her numbers in Vallières et al.). ${ }^{334}$ Before 1718 , Lunn proposes that 70,000 pounds of beaver (the largest fur export) was exported to La Rochelle (the port which was nearly exclusively the destination of all Canadian furs). I have assumed that this poundage sold at 2 livres per pound. Akin to Altman, I believe that relying on this estimate to measure fur exports before 1718 might bias our pre-1718 results downwards. I have also kept important specifications from

\footnotetext{
${ }^{331}$ Marc Egnal. 1998. New World Economies: The Growth of the Thirteen Colonies and Early Canada. Oxford: Oxford University Press, p. 131.

332 Richard Harris. 1966 [1984]. The Seigneurial System in Early Canada. Montréal: McGill-Queen's University, p.114

${ }^{333}$ Alice Jean Lunn. 1942. Economic Development in New France, 1713-1760. Montréal, PhD Thesis, Department of History, McGill University, pp.456-465.

${ }^{334}$ Vallières, M. and Charbonneau, A. (2008). Histoire de Québec et de sa région, vol. I. Québec : Presses de l’Université Laval, p.138.
} 
Altman's work on the fur trade. The fur output estimates from 1688 are adjusted downward to account for a $25 \%$ tax on beaver that lasted until 1717 and was embedded in the price of fur. I also deflated an additional $13 \%$ for the entire period so as to account for the value of trade goods used as inputs in the trade with Indians - this avoids double counting.

\section{Population}

As for population size, I have relied on Lalou and Boleda who revised census data to avoid the under-enumeration problem. ${ }^{335}$ The fourth volume of the census of 1871 contained a series of population estimates - which can also be found in a more readily usable format in the MA thesis of François Aubry. ${ }^{336}$ However, Lalou and Boleda pointed out that the census estimates generally underestimated the overall population of the colony. This problem is common to the entire preconfederation era in Canada and extends well beyond Quebec. ${ }^{337}$ The corrections of Lalou and Boleda estimated the under-enumeration using the natural increase of population through immigration and births minus deaths and emigration as a benchmark. They found that there was an omission rate of roughly $10 \%$ of the population. Helpfully, they provided their estimates of corrections_-which are used here.

\section{Extending to circa 1762}

The problem is that the census data needed to estimate output after 1739 is of very low quality. One has to wait until the census of 1827 to obtain a colony-wide measure of agricultural output. To be sure, there were censuses in 1765, 1784 and 1790. However, none of those censuses asked questions regarding crops harvested. The census of 1765 is the subject of numerous criticisms, notably because very little is known about the instructions given to enumerators. ${ }^{338}$ Nonetheless, it is possible to create an estimate of output circa 1762 using the partial census of the Trois-Rivières district. This district, which represented roughly $10 \%$ of the population of the colony, was administered after the conquest by Thomas Haldimand — who would later be governor of the colony as a whole during the American war of Independence. During his administration of that military district, he did make a census — which is not void of problems. Generally, historians use the census details provided by the Rapport de l'Archiviste de la Province de Québec for 1946. However, that version does not contain any measurements of agricultural production. Fortunately,

\footnotetext{
335 Richard Lalou and Mario Boleda. 1988. "Une source en friche : les dénombrements sous le Régime français", Revue d'histoire de l'Amérique française, Vol.42, no.1, pp.47-72.

336 François Aubry. 1970. Indicators of Economic Growth for Lower Canada, 1760-1850. Ottawa: MA Thesis, Department of History, University of Ottawa.

337 Bruce Curtis. 2002. The Politics of Population: State Formation, Statistics, and the Census of Canada, 1840 to 1875. Toronto: University of Toronto Press.

${ }^{338}$ Yves Landry. 1975. "Étude critique du recensement du Canada de 1765”, Revue d'histoire de l'Amérique française, Vol.29, no.3, pp.323-351.
} 
Haldimand was a very thorough record-keeper and his collection of documents - stored at the British Library - has been a treasure trove for Canadian historians for decades. Quite by accident while consulting these archives, I discovered an annex to the census of 1762 for Trois-Rivières which was titled "Recensement des grains recueuillis dans les différentes paroisses du Gouvernement des Trois-Rivières pendant la présente année 1762" (A census of grains collected in the different parishes of the government of Trois-Rivières in 1762). ${ }^{339}$ With the use of that, I can extrapolate overall output in the colony around 1762. Naturally, there are caveats to this data. I cannot know how to properly weight the Trois-Rivières area in 1762 relative to the rest of the colony as there is such a great interval between the 1739 census and the 1827 census. As a consequence, the estimate generated for 1762 should be used with considerable caution. The reason for this is that it is hard to assess how representative Trois-Rivières as a district was during the eighteenth century. ${ }^{340}$

The methodology used to compute output in 1762 is exactly the same as described above. Unfortunately, some prices were unavailable for that year which prevented me from estimating nominal GDP. As a result, only the quantity index — with base year 1739 — can be used. The only difference is that output was estimated by assuming that agricultural production, land farmed and population in Trois-Rivières were equal to that of the district's share of total population in the census of $1765(9.45 \%){ }^{341}$ This share is then used to extrapolate total output. To obtain output net of seed, the normal method was to assume that 2 minots were required per arpent and that $75 \%$ of all cultivated lands were used to grow wheat. However, the census of 1762 for Trois-Rivières offered only the amount of conceded lands - not cultivated land. I had to use an arbitrary

\footnotetext{
${ }^{339}$ British Library, Haldimand Collection, Additional Manuscripts 21681-21682, available at Library and Archives Canada (LAC) as reel H-1431, p.25.

${ }^{340}$ The next best census that allows us to compare Trois-Rivières with other areas is the Bouchette census of 1827 and the official census of Lower Canada of 1831 (see notably: François Aubry. 1970. Indicators of Economic Growth for Lower Canada, 1760-1850. Ottawa: MA Thesis, Department of History, University of Ottawa; Public Archives of Canada. 1876. Volume IV of the 1871 Census of Canada. Ottawa: Department of Agriculture). In those censuses, Trois-Rivières has production figures of wheat per capita moderately above the colonial average $(13 \%$ and $10 \%$ above). But that is probably a result of geographic reorganization. The 1762 boundaries of the Trois-Rivières area were limited to settled areas between the Quebec and Montreal districts on both shores of the St-Lawrence river. But the district's population did not go deeper than 50 kilometres on both shores. However, after the American revolution, waves of settlers settled the Estrie region which, by the time of the 1827 and 1831 censuses, was included inside the Trois-Rivières district. Farmers in the counties of Drummond and Sherbrooke which were part of the Trois-Rivières district used to report volumes in bushels rather than minots $(1 \mathrm{minot}=1.107$ bushels). Censuses like those of 1827 and 1831 are known to suffer from uncertainties related to the weights used by the population and the weights reported by enumerators. If the volumes reported were in bushels but reported as minots in these areas, production would have been overestimated by $10.7 \%$ (Marvin McInnis. 1981. "Some Pitfalls in the 1851-1852 Census of Agriculture of Lower Canada." Histoire sociale/Social History, No.27, pp.219-231). But even accounting for this fact, the TroisRivières district seems to have been moderately better off than the colonial average in terms of production. As a result, we can infer that, if the nineteenth century differences apply to the 1762 census as well, my estimates for 1762 overshoot the level modestly.

${ }^{341}$ The census of 1871 , volume IV provides the all the colony-wide censuses up to that date. Public Archives of Canada. 1876. Volume IV of the 1871 Census of Canada. Ottawa: Department of Agriculture.
} 
assumption that $25 \%$ of all land owned was cleared - an assumption not far from the overall estimate found for other estates like the Isle Jésus. The number of animals was taken from the census of 1765 and adjusted for the estimated population of 1762. The main remaining issue is the fact that the data for furs export is non-existent and since it was very volatile, the estimation is quite problematic. As a result, I opted for a conservative approach whereby I kept the per capita fur exports of 1739 and applied them to the 1762 figure. These represent a rough measure of output per capita in 1762. The quality is below that of the estimates between 1688 and 1739. It probably overstates the true level of output per capita because of two assumptions made earlier: a) fixing firewood output by assuming that 20 cords of wood were harvested per household; b) that urban dwellers worked a fixed number of days. In 1762, the economy was recovering from the shock of an important war in which the city of Quebec had been largely destroyed and a large military contingent occupied the colony since the French had surrendered in 1760. In addition, there had been significant inflation as a result of a second experiment with fiat money within the colony. Given these facts, it is hard to fathom that production of firewood and non-agricultural production did not suffer any setbacks. As a result, the 1762 estimates are probably above where they truly were-even though it represents the lowest point in the series.

\section{Results}

Table 4.1 below presents the results of the two measures of GDP in comparison with the initial estimates of Altman. As one can see from this table, the two quantity indexes (mine with 1739 prices and Altman's with 1749 prices) move in similar magnitudes (in fact, their movements are identical in amplitude and direction over the entire period. However, the series of nominal GDP deflated by the price index computed in part 3 shows a different story. There is an significant drop in real incomes between 1688 and 1720. After 1720, they move in line at the same levels again. These differences are quite important for two reasons. The first is war. Between 1688 and 1713 (with a small gap at the end of the seventeenth century) the colony is caught in the middle of the French and English and during this period, was subjected to British Naval incursions (1692 and 1711 - although the latter ended terribly). The differences between the two series show that when wars pushed up prices, the inhabitants of the countryside probably did not alter their production very much. The quantities produced per capita stayed relatively stable in spite of massive fluctuations in price. The second relates to the playing card money experiment which created serious inflation from 1714 to 1719 . However, peasants again did not alter their production dramatically. This suggests that the money shock caused by this experiment did not translate into a real shock to economic production. The return thereafter to the same level of the different series suggest that once peace returned and nominal prices returned to some predictable path, production would follow the same path. Overall, these corrections suggest that Altman was correct in his estimation that there was positive growth. Yet, one should be careful not to dismiss the role of supply-side shocks caused by wars, and monetary shocks caused by the playing card experiment. This created volatility in prices which depreciated the real value of estates as recorded in probate 
inventories as well as reduced the peasants' perception of reliability in markets. Nonetheless, all these series indicate that over the long-run-volatility or not - there was a positive trend in real income per capita. Between 1688 and 1739, income per capita grew by $0.30 \%$ according to the quantity index and $0.46 \%$ according to the deflated nominal GDP - a very minor difference. In 1762, after the Seven Years War, living standards has fallen to their lowest level since 1698 and were below the level observed in 1688 - overall, this confirms that there was very little growth in the colony over time. This can be seen graphically in Figure 4.3. There is a difference in level for the Altman series and my own, but this is only because I used 1739 prices rather than 1749 prices as weights. If they are indexed, the two series are nearly identical yielding nearly equal long-term rates of growth.

Table 4.1. Income per capita according to different measures in real terms (in livres)

\begin{tabular}{|c|c|c|c|c|c|c|c|}
\hline Year & Altman & $\begin{array}{l}\text { Quantity } \\
\text { Index } \\
\text { (1739 } \\
\text { prices) }\end{array}$ & $\begin{array}{l}\text { Nominal } \\
\text { GDP } \\
\text { deflated } \\
\text { (1739 } \\
\text { prices) }\end{array}$ & Year & Altman & $\begin{array}{l}\text { Quantity } \\
\text { Index } \\
\text { (1739 } \\
\text { prices) }\end{array}$ & $\begin{array}{l}\text { Nominal } \\
\text { GDP } \\
\text { deflated } \\
\text { (1739 } \\
\text { prices) }\end{array}$ \\
\hline 1688 & & 104.00 & 101.65 & 1722 & 123.00 & 117.09 & 122.48 \\
\hline 1695 & 115.00 & 104.27 & 78.14 & 1723 & 120.00 & 129.41 & 144.39 \\
\hline 1698 & 108.00 & 100.26 & 78.79 & 1724 & 120.00 & 106.77 & 101.53 \\
\hline 1706 & 113.00 & 103.65 & 92.79 & 1726 & 126.00 & 110.27 & 103.53 \\
\hline 1707 & 107.00 & 98.29 & 81.25 & 1727 & 150.00 & 135.65 & 169.42 \\
\hline 1712 & 123.00 & 110.96 & 83.18 & 1730 & 134.00 & 126.02 & 143.29 \\
\hline 1713 & 111.00 & 102.91 & 87.13 & 1732 & 126.00 & 114.60 & 128.92 \\
\hline 1714 & 126.00 & 103.34 & 79.64 & 1734 & 146.00 & 134.15 & 145.98 \\
\hline 1716 & 125.00 & 107.42 & 74.98 & 1736 & 133.00 & 113.58 & 123.19 \\
\hline 1718 & 110.00 & 106.99 & 87.95 & 1737 & 95.00 & 92.62 & 97.58 \\
\hline 1719 & 146.00 & 124.12 & 85.56 & 1739 & 138.00 & 121.42 & 128.74 \\
\hline 1720 & 143.00 & 113.67 & 116.28 & 1762 & & 98.26 & \\
\hline 1721 & 114.00 & 111.27 & 113.26 & & & & \\
\hline
\end{tabular}


Figure 4.3. Real income per capita according to different computation methods (in livres)

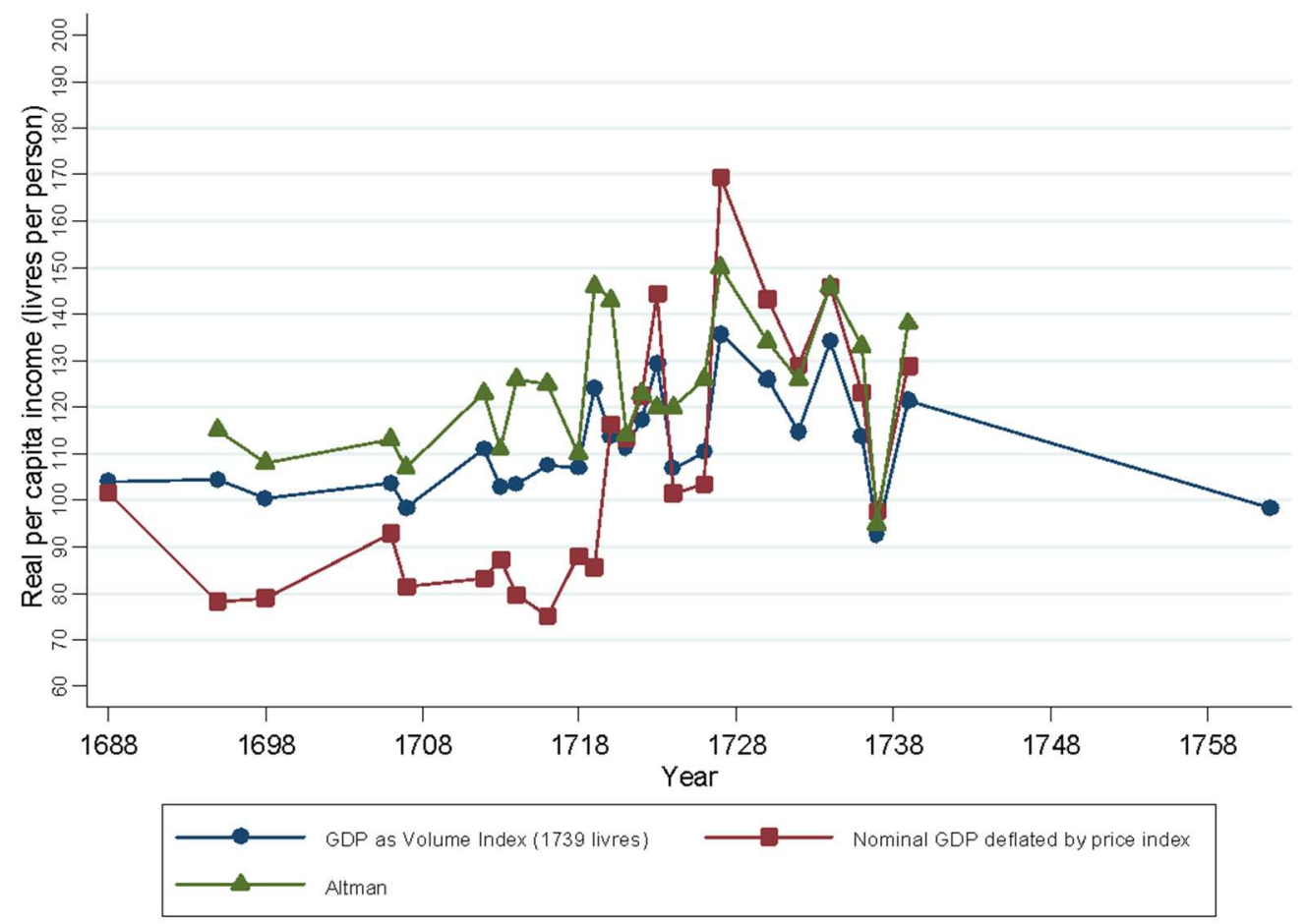

In short, the worries expressed by Desbarats do not materialize as the overall conclusion of Altman is not altered. Although it is more volatile, the nominal GDP deflated by the price index shows the same long-run trend as both quantity indexes of GDP (Altman's and mine). The volatility is to be expected. Prices did change more than quantities from census to census. However, since living standards are about quantities, the volume index approach used by myself and Altman is better. In addition, the long term levels seem to converge (see 1739 values for both series) regardless of the method used. The change of computation techniques and base year for prices do not change much between the two quantity indexes. This now being said, I can advance with greater certainty that there was some economic growth. This growth was only present up to the Austrian War of Succession in 1740. The trend between the peace year of 1688 and the peace year of 1739 (which was the last census year of a long period of peace between 1713 and 1740) suggests that the per capita growth rate stood at roughly $0.35 \%$ percent per annum. In peacetime, there was a positive rate of growth. By extending to 1762, I see that whatever growth had been achieved up to the War of Austrian Succession had been rolled back. This long-term picture suggests that New France had a rate of growth close to the zero rate of growth found, for the American colonies, by Mancall and Weiss. ${ }^{342}$ In fact, the rate of growth is negative $0.08 \%$ per annum between 1688 and circa 1762 .

342 Peter Mancall and Thomas Weiss. 1999. "Was Economic Growth Likely in Colonial British North America" Journal of Economic History, Vol.59, no.1, p.17-40. 
We can also use the figures to measure the relative contributions of each sector to the total economy. My weights show that between 1688 and 1762, the agricultural sector contributed $61 \%$ of total output compared with $26 \%$ for the non-agricultural sector and $12 \%$ for the fur exports business. These proportions might seem surprising for some. They should not be. First of all, urban areas represented somewhere between $21.18 \%$ and $25.8 \%$ of the population of New France. Finding that non-agricultural output represented roughly $26 \%$ of total output is not that strange. Moreover, the overall weights are affected by the presence of fur exports. This was an important source of output for the colony. A part of this output would have accrued to farm households who, during the winters, did to some extent venture into the fur trade.

We can also use the data above to propose an extension of the comparisons of welfare ratios based on wages. The measure of output derived here should be taken as a proxy for gross output estimates rather than value-added estimates as proper GDP figures should be. Nonetheless, I could use these to see if switching to income per capita changes the comparisons of welfare ratios between the French and British colonists. If I take the per capita pound sterling income provided by Lindert and Williamson for the American colonies between 1675 and 1750, I can create a comparison with our estimates with New France by converting on the basis of silver grams. ${ }^{343}$ This is possible since the calculation of the nominal GDP measure, meant to counteract Desbarats' criticisms, provides a measure of annual nominal income which can be turned into silver gramsincome. This can be seen in Figure 4.4. Obviously, the nominal income in grams of silver is not an ideal measure of comparisons given differences in price levels. However, the first thing that appears clearly here is that New France is considerably below the level observed for the American colonies. Secondly, it seems that the gap is expanding over time relative to the American colonies. Thirdly, New France is well below England at that time - so are the American colonies. Lindert and Williamson argue that comparisons of nominal incomes expressed in a standardized currency (in their case, their tables use pounds sterling) should be converted into welfare ratios. I have interpolated incomes from Lindert and Williamson to obtain values for 1688 and 1740 in order to compare with New France. The basket for bare bones welfare ratios are extracted from Chapter 4 of the current dissertation. The outcome of this appears in Figure 4.5. As can be seen, all the data confirms that New France is doing poorly relative to the American colonies, by a relatively similar gap to the one observed with real wages in Chapter 3. However, the data also shows that there is a change in the relative position of England to all the other areas. Rather than being "poorer," England is actually richer than New England. Some might be surprised. I am not. This result is the same as the one obtained by Lindert and Williamson in their work. In their work, New England living standards in 1750 were equal to $88 \%$ of those in England. My own specifications are slightly

\footnotetext{
${ }^{343}$ Peter Lindert and Jeffrey Williamson. 2014. American Colonial Incomes, 1650-1774. Cambridge, MA : National Bureau of Economic Research
} 
different, but the differences are the same. The level of incomes calculated by Lindert and Williamson upon which I rely were calculated using, in some instances, an assumption about length of work year (something I do not have to do to generate my measure of income in New France). As a result, I stand on the quality of their work. However, there are very few reasons to doubt their end results given that they themselves are relying on Alice Hanson Jones' massive database of wealth at time of death. However, even if I am convinced by their work, some may not be and this is mentioned here for the sake of transparency. If there were differences, they would be minor and would not change the fact that England is better off than its colonial offshoots during that era. British workers could compensate for lower wages with longer work years in order to achieve greater incomes. Workers in Pennsylvania might have been better able to do so, but workers in New England would have had a harder time given the temperature of Massachusetts. New France would have faced the same situation. This difference in standardized real incomes shows that while New France's position relative to the American colonies remains unchanged by the measurement system used, its relative position to France and England deteriorates when I use income. This is probably because of the length of the work year. The harsh winters of Canada imply shorter seasons and fewer days of work. As a result, its situation relative to France and England presented in Chapter 3 must be overestimated. Consequently, I can argue that New France was poorer than all of the comparatives used here (with the exception of Latin America). 
Figure 4.4. Comparing incomes (current) in grams of silver

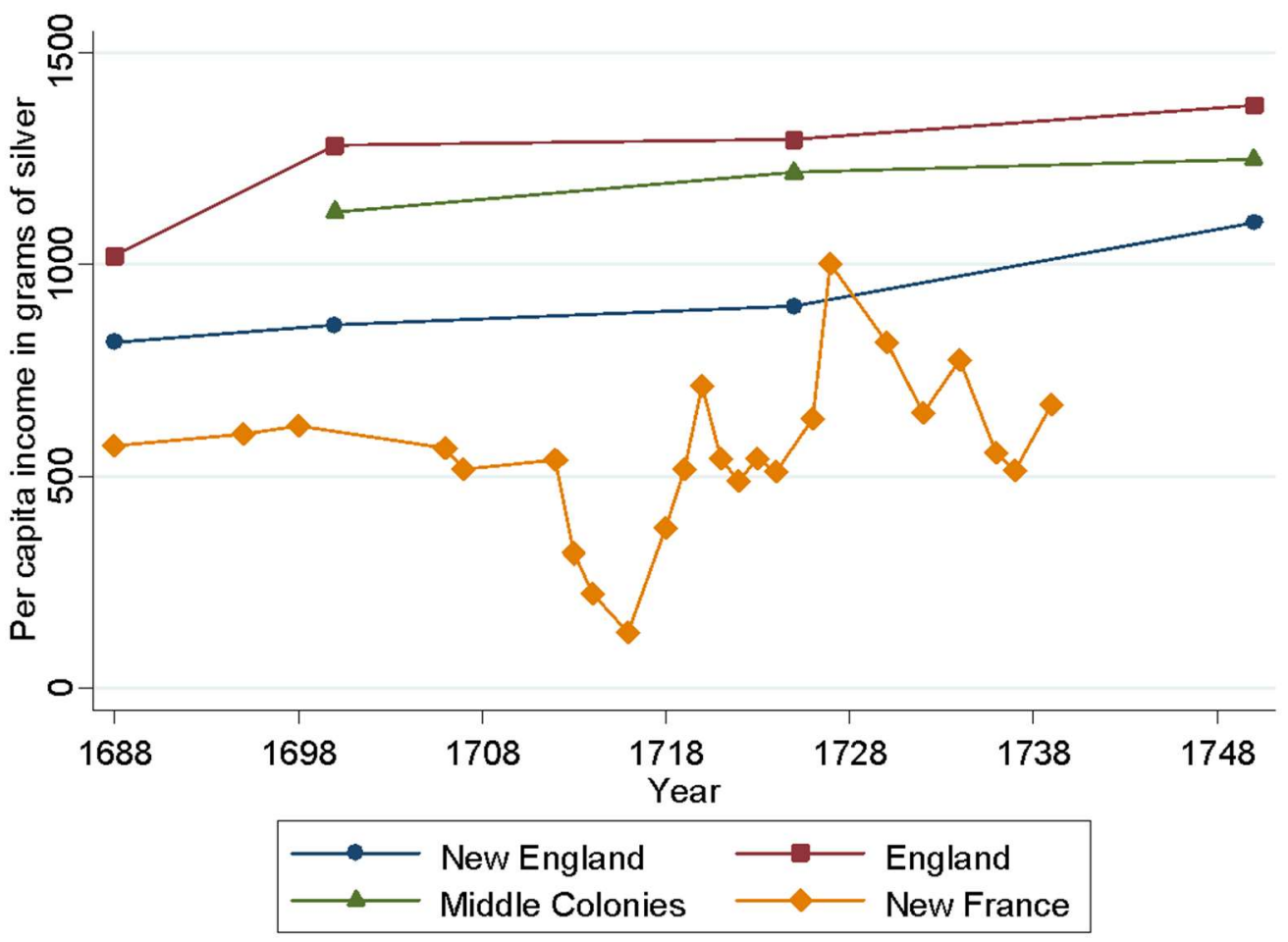

Source and notes: The year 1688 for all areas except New France is based on the linear interpolation between 1675 and 1700. The price of silver for New France was derived from the work of Yvon Desloges (1991. A Tenant's Town: Quebec in the $18^{\text {th }}$ century. Ottawa: Parks Canada). The problem is that there are some gaps (in some of the early years and after 1749) and that I cannot rely on the French silver conversion ratio (since it does not behave in the same manner) after 1749. As a result, I confined my use of the price of silver in Desloges' work to 1688-1739. In addition, Desloges reported prices in the Livres de France accounting system, which required me to enact conversions on the basis of the Livres $d u$ Canada (the unit in which I recorded prices and wages). The conversion between accounting systems was taken from the work of Louise Dechêne.1994. Le Partage des Subsistances au Canada sous le Régime Français. Montréal: Éditions Boréal, p.198 although she made a small mistake and the rate for 1713-1718 actually extends to 1719 . 
Figure 4.5. Comparing incomes (current) in bare bones welfare ratios

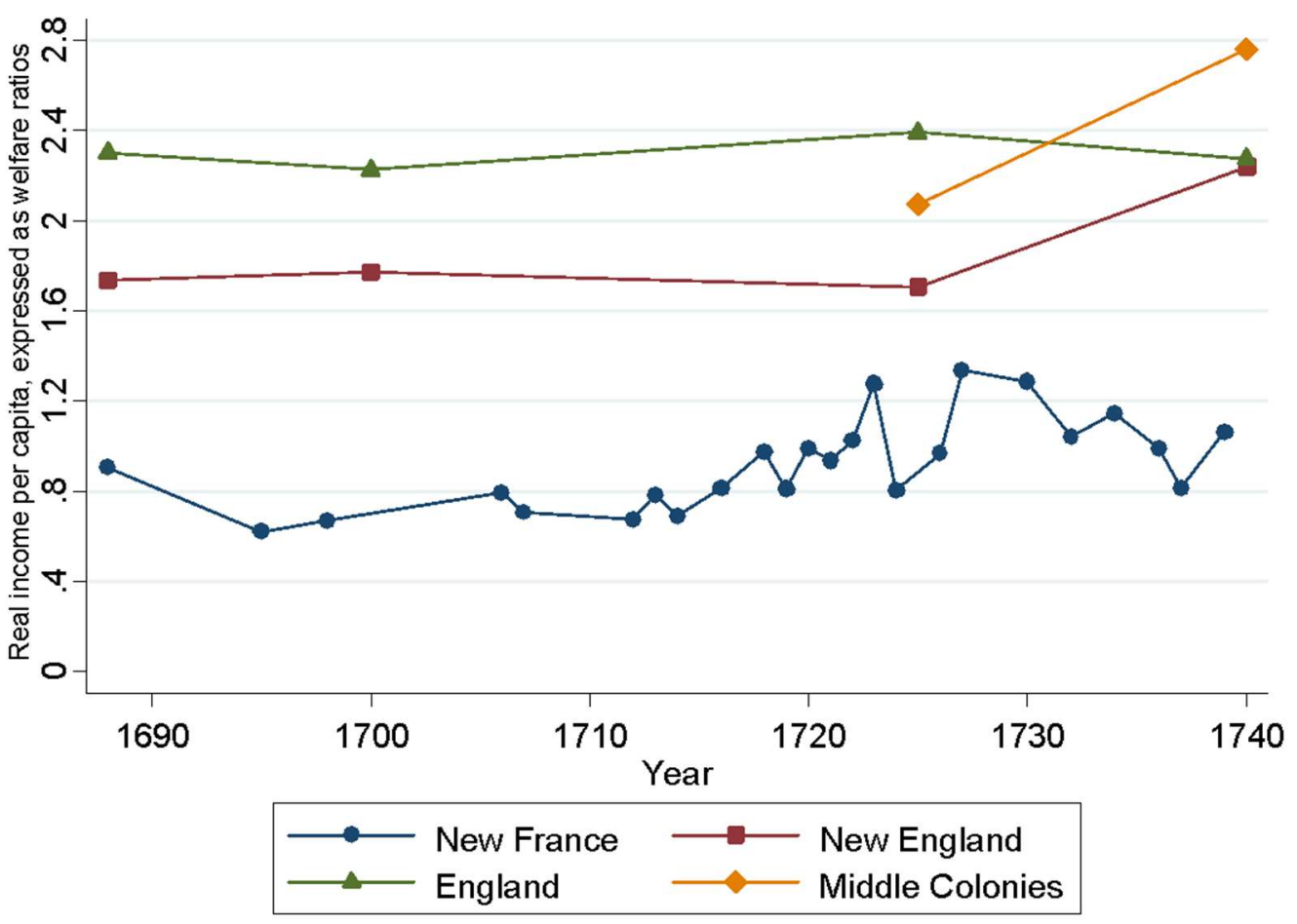

Note: In their work, Lindert and Williamson used Allen et al. cost of the bare bones basket. They deflated incomes by a five-year average of that basket. I have used the same procedure here, but I relied on the basket I constructed in Chapter 4. I also produced the same figures with respectable baskets and it showed the same conclusions as for welfare ratios. For the sake of brevity, I decided not to add that figure in my work since it would have been redundant.

\subsection{Puzzling observations}

The answers provided by the new GDP measurements raise a new set of problems. The episode between 1688 and 1739 where there is some growth observed needs some explaining as welfare ratios using wage rates show none. A likely candidate to explain this growth which occurred in peacetime is that households increased their labor supply in a manner suggestive of the industrious revolution. ${ }^{344}$ This would reconcile the stagnation in real wages with the modest increase in per capita income. The problem is that the measurement of labor supply could be the subject of another dissertation in of itself. Thus, the evidence that can be marshalled in that regard is tentative at best.

\footnotetext{
344 Jan de Vries. 2008. The Industrious Revolution: Consumer Behavior and the Household Economy, 1650 to the Present. Cambridge: Cambridge University Press.
} 
The first piece of evidence supporting an increase in labor supply that would have increased incomes up to 1740 is related to land clearing. The amount of work required to clear new land is considerable. It is estimated that clearing an acre of land in early nineteenth century America required roughly one month's labor plus a pair of oxen. ${ }^{345}$ However, while a household cleared that acre of land, it still needed to be fed and clothed. In the words of Susan Previant Lee and Peter Passell: "the fact that the farmer would do the work on his or her own time doesn't eliminate the cost of the operation - a month of farm labor devoted to land clearing was a month in which the family still had to be fed, sheltered and clothed." 346 In short, if his productivity is assumed to be fixed, the only way a peasant can accomplish such a feat is either to reduce his consumption or increase the number of days worked in a year. From the 1720 s to 1730 s, the land area cultivated per agricultural family roughly doubles as can be seen in Figure 4.6. My core claim is that this increase in farming activities through land clearing is a proxy for the increase in labor supply.

Figure 4.6: Arpents cultivated per agricultural family, 1688 to 1739

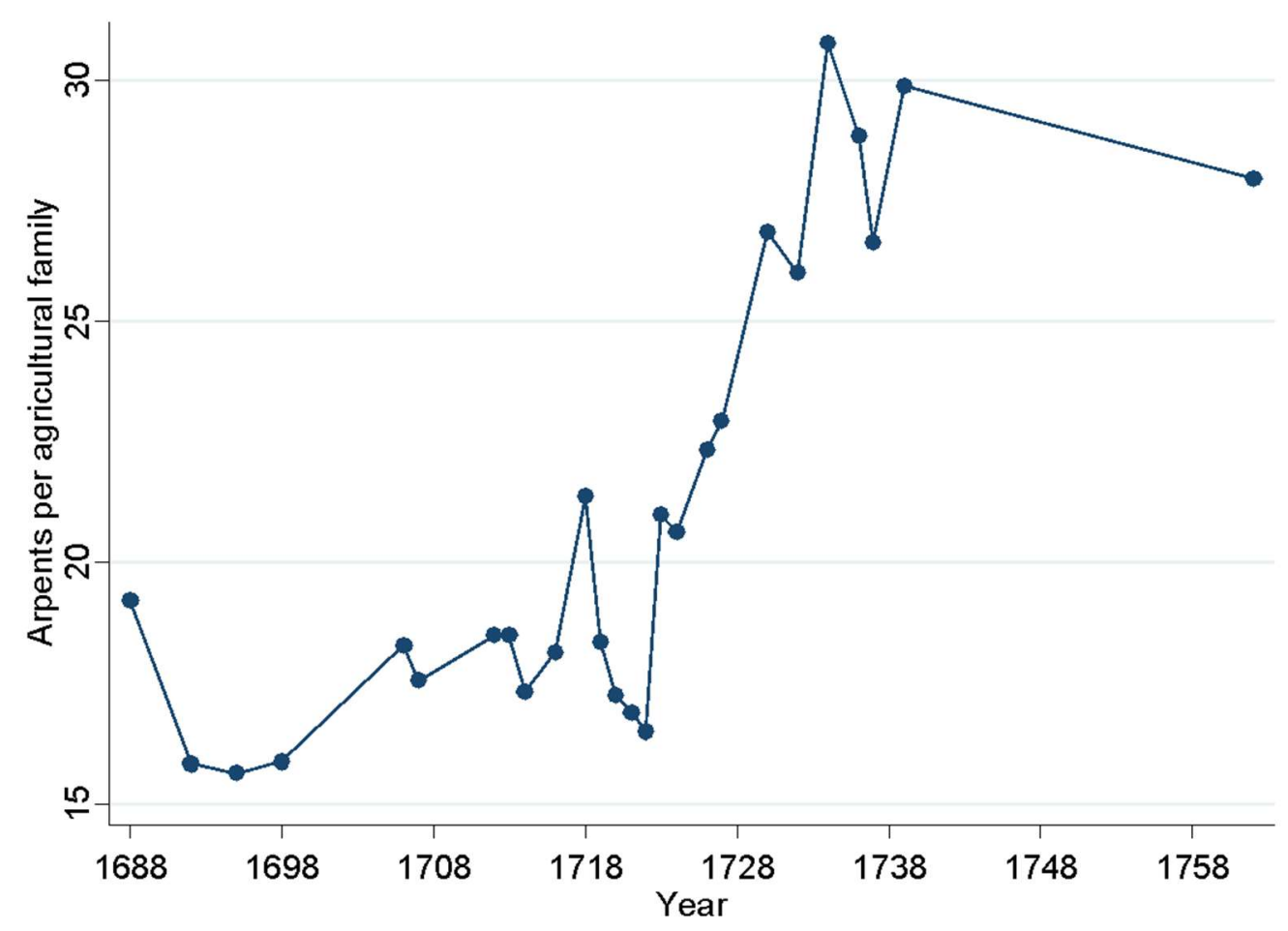

Source: Alice Jean Lunn. 1942. Economic Development of New France, 1713-1760. Montréal, PhD thesis, McGill University, p. 443-444; Public Archives of Canada. 1876. Volume IV of the 1871 Census of Canada. Ottawa: Department of Agriculture; agricultural families were defined as the share of the population not in cities divided by the modal family size of 6 .

345 Martin L.Primack. 1962. "Land clearing under nineteenth-century techniques: some preliminary calculations." Journal of Economic History, Vol.22, no. 04, pp.484-497.

${ }^{346}$ Susan Lee Previant and Peter Passell. 1979. A New Economic View of American History. New York: Norton, p.137. 
The second piece of evidence is not ideal, but it is nonetheless suggestive. The evidence collected from the Archives of the Séminaire de Québec was consisted of annual, monthly and daily wages. Originally, the daily wages were collected for the purposes of measuring living standards and the other forms of wages were only collected to compare in order to assess the reliability of daily wages. Yet, I can derive a crude measure of the intensity of work by dividing annual wages by the daily wages. By no means is this meant to measure the exact number of days worked in a year. Converting the annual wages into a usable form would have been a dissertation in itself and may be a topic of my future research. Notwithstanding, I can use the movements of this ratio as a proxy for the amount of labor supplied in a year. This should only be construed as a piece of suggestive evidence, rather than as definitive evidence and should also be read in context with the other information advanced. The period between 1720 and 1739 does show that —at the same time that land clearing intensified - the ratio of annual wages to daily wages also increased by an average of $18.8 \%$ relative to the period from 1689 to 1720 .

Table 4.2. Average annual number of days worked per period

\begin{tabular}{cc} 
Period & Ratio of annual wages to daily wages \\
\hline $1689-1720$ & 80.42 \\
$1720-1739$ & 95.52 \\
Difference (\%) & $+18.8 \%$ \\
\hline
\end{tabular}

The third piece of evidence-which is the weakest of the three I can offer in support of the hypothesis that households worked longer and harder - is that the climate improved. The era of French rule was marked by appreciable climate warming. By virtue of this improvement in climate, it might be that the harvest season lengthened inciting greater production through longer and harder work. ${ }^{347}$ However, this is highly speculative and it is only considered as supportive of the two other pieces of evidence provided.

For heuristic purposes, let us assume that the proposition that labor supply increased sufficiently solves the issue of the differences between real wages and real income from 1688 to 1740. This spawns another, more important, issue. During the same period, there are clear signs of a decline in the biological standard of living most notably substantial increases in infant mortality and the overall crude death rate.

\footnotetext{
347 Steve McIntyre and Ross McKitrick. 2003. "Corrections to the Mann et. al.(1998) proxy data base and northern hemispheric average temperature series” Energy \& environment, Vol.14, no.6, pp.751-771; M.E Mann., R.S. Bradley., and M.K. Hughes. 1998. "Global-scale temperature patterns and climate forcing over the past six centuries". Nature, Vol.392, No. 6678, pp.779-787. Victoria Slonosky. 2003. "The meteorological observations of Jean-François Gaultier, Québec, Canada: 1742-56" Journal of Climate, vol.16, no.13, pp.2232-2247; Daniel Houle, Jean David Moore et Jean Provencher. 2007. « Ice bridges on the St-Lawrence River as an index of winter severity from 1620 to $1910 »$ Journal of Climate, vol.20, no.4, pp.757-764.
} 
Thanks to the work of Marilyn Gentil, mortality quotients for the infant population were constructed. ${ }^{348}$ Her set of data is taken only for the legitimate births and likely (at her own admission) understate modestly the true level of infant mortality. This is because illegitimate births generally meant abandonments whereby the children would die or, with luck, be taken in by religious congregations. Yet, the trend is unmistakable - there is a powerful increase in infant mortality in the colony over time whereby the level roughly tripled between 1678 and 1760 (Figure 4.7). Relative to the start of the data, infant mortality follows a steep upward trend throughout the French regime (however, the level stabilises from 1760 to the end of Gentil's series in 1778). A substantial part of that increase occurred between 1688 and 1740. The subsequent increase from 1740 to 1760 is not hard to explain given that there were shocks in the form of invasion and military occupation and both real income and wages fell. The increase in infant mortality up to 1740 is more problematic since real wages stagnated and real incomes suggest a modest increase in living standards. The same reality can be observed with the crude mortality rate (see Table 4.3). ${ }^{349}$

Table 4.3. Births per marriage, death rates and infant mortality quotients

\begin{tabular}{lccc} 
& Births per marriage & $\begin{array}{c}\text { Death rate (entire } \\
\text { population) }\end{array}$ & Infant mortality quotients \\
\hline $1688-1698$ & 4.9 & 14.6 & 155.7 \\
$1699-1708$ & 6.3 & 25.1 & 173.9 \\
$1709-1718$ & 5.8 & 24.7 & 187.4 \\
$1719-1728$ & 5.7 & 20.6 & 180.3 \\
$1729-1738$ & 5.9 & 27.7 & 217.3 \\
$1739-1748$ & 5.8 & 26.3 & 256.4 \\
$1749-1760$ & 5.3 & 35.0 & 291.0 \\
\hline
\end{tabular}

\footnotetext{
${ }^{348}$ Marilyn Gentil. 2009. Les Niveaux et les Facteurs Déterminants de la Mortalité Infantile en Nouvelle-France et au début du Régime Anglais (1621-1779). PhD thesis, department of demography, Université de Montréal. The probability of dying between birth and one year of age is the quotient of infant mortality. It is calculated by dividing the number of deaths in that age group by the number of individuals in that same age group at any given point in time. It is not the same as dividing the number of deaths between 0 and 1 years of age by the total number of births in the year of death. However, the evolution is similar and need not worry us (see page 53).

${ }_{349}$ Vincent Geloso and Vadim Kufenko. 2015. "Malthusian pressures: empirical evidence from a frontier economy", Journal of Population Research, Vol. 32, no. 3-4, pp.263-283.
} 
Figure 4.7. Infant mortality quotients in New France, 1638 to 1760

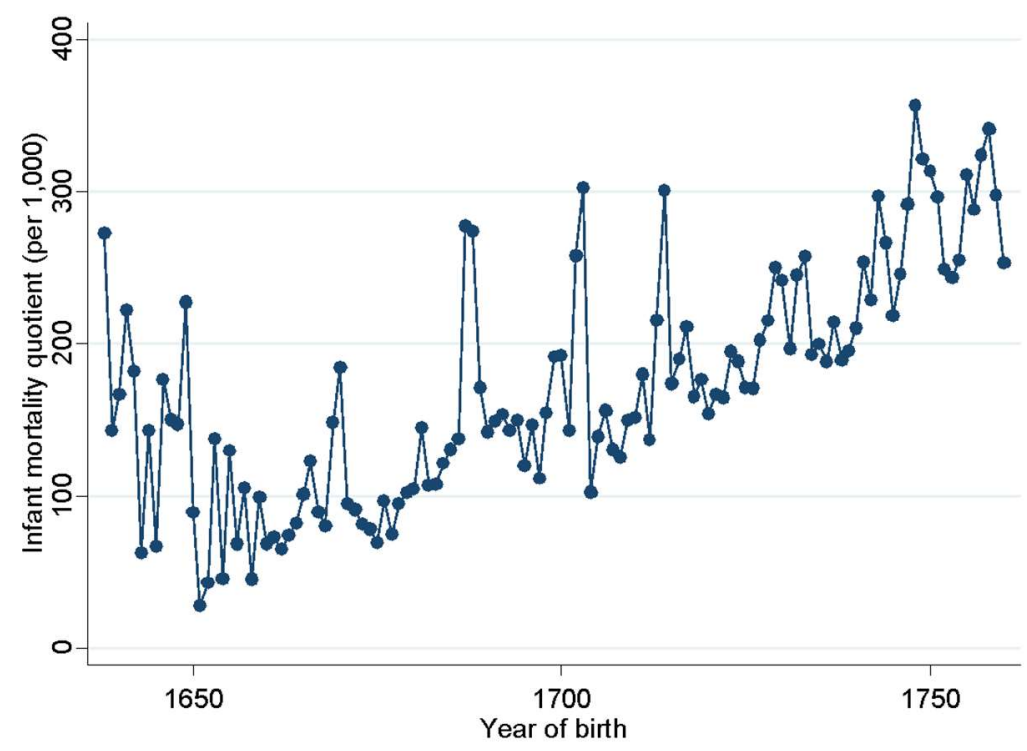

The number of births per marriage also supports the contention that there was an increase in children who died in early infancy. To reach the average family size of six persons, if all children survived, the number of births per marriage should be equal to four (two adults and four children). However, according to the data collected by George Langlois from parish records, it was nowhere near this figure. ${ }^{350}$ In fact, there tended to be above 5.5 births per marriage in peacetime (see first column of Table 4.3). Greater numbers of children dying in early infancy means that many were "partially raised" since they would die without contributing to household production. ${ }^{351}$

The issue is that all of this was occurring at the same time that income were increasing (or at the very least, living standards were not falling as illustrated by real wages). This represents an important puzzle. Higher infant mortality could be explained by a combination of factors. Some are linked to the immediate family after birth. The great size of families meant that there was high competition for calories among siblings. Other factors would be related to the health of the mother during the pregnancy. For example, mothers gave birth at younger ages at which it was riskier for them and for the fetus. ${ }^{352}$ It could be related to maternal nutrition during pregnancy whereby a woman would have expended more energy than was required by her body which would impact the

\footnotetext{
${ }^{350}$ George Langlois. 1935. Histoire de la Population Canadienne-Française. Montréal: Éditions Albert Lévesque. ${ }^{351}$ Jane Humphries. 2013. "The lure of aggregates and the pitfalls of the patriarchal perspective: a critique of the high wage economy interpretation of the British industrial revolution", Economic History Review, Vol. 66, No.3, p.705.

352 There is very little reliable data about the evolution of the age at first marriage, but what little exists points to an average age of 20 years for women and 28 for men: Lorraine Gadoury, Yves Landry and Hubert Charnonneau. 1985. "Démographie différentielle en Nouvelle-France: villes et campagnes", Revue d'histoire de l'Amérique française, Vol.38, no.3, p.367.
} 
developing child and its early chances of survival. ${ }^{353}$ If the increase in household labor supply came from making women work longer and harder, this could partially explain the increase in infant mortality. An increased demand for child labor and women's labor could have led to future health complications. In the case of pregnant women, poor nutrition during pregnancies implied that hormone production would be affected. This would hurt the fetus and lead to adaptations that are suited for short-term survival at the expense of potentially adverse lifetime effects. These effects which materialize later in life shorten life expectancy. ${ }^{354}$ The increase could also have resulted from relying more on child labor. For children, harder work meant that "growth can also be affected if the child is expected to undertake significant manual work." ${ }^{355}$ This is quite important given that Robert Fogel has identified that mortality risks are higher when individuals are shorter. ${ }^{356}$ Early childhood experience with hard work would have translated into higher health risks which would, if not accompanied by an increase in calorie intake, mean a higher death rate later in life. However, all these propositions are speculative.

Modern labor economics attribute low elasticity of labor supply to men and a higher one to women. ${ }^{357}$ Mid-age male workers also exhibit low elasticity because the alternative of "not working" to "working" is incredibly costly. It also means that he cannot increase his labor supply significantly. Elasticity tends to be higher at young and old ages, workers adopt "corner solutions" whereby they enter the market later or leave it earlier. ${ }^{358}$ Hence, if a household decides to increase labor supply, it will tend to look at other members of the household than the male adult who is already tied up. This means an increased participation on the part of children and women. For New France, what this literature suggests is that most of the increase in the income per person which came from increased labor participation actually came from increased labor participation from women and children.

The current section is quite speculative. It merely aims to highlight a puzzling observation and possible avenues of research. In order to be fully convincing, calculations of calories produced, expended, and lost in processing would have to be made. The problem is that the state of the data

\footnotetext{
${ }^{353}$ David Meredith and Deborah Oxley. 2014. "Nutrition and health, 1700-1870" in eds. Roderick Floud, Jane Humphries and Paul Johnson, The Cambridge Economic History of Modern Britain, Vol.1, 1700-1870. Cambridge: Cambridge University Press, p. 142-144.

${ }^{354}$ Keith Godfrey and David Barker. 2000. "Fetal nutrition and adult disease", American Journal of Clinical Nutrition, Vol.71, no.5, pp.1344-1352.

${ }^{355}$ Roderick Floud, Robert Fogel, Bernard Harris and Sok Chul Hong. 2011. The Changing Body: Health, Nutrition and Human Development in the Western World since 1700. Cambridge, MA: National Bureau of Economic Research, p.11.

${ }^{356}$ Robert Fogel. 2004. The Escape from Hunger and Premature Death, 1700-2100: Europe, America and the Third World. Cambridge: Cambridge University Press, pp. 23-27.

${ }^{357}$ Michael P. Keane. 2011. "Labor supply and taxes: a survey”, Journal of Economic Literature, Vol.49, no.4, pp.9611075 .

${ }^{358}$ Lars Ljungqvist and Thomas Sargent. 2011. “A Labor Supply Elasticity Accord?” American Economic Review, Vol.101, no.3, pp.487-491.
} 
does not permit such computations to be satisfactorily reliable. Height data for New France are impossible to find - the religious institutions used in this thesis did not record any heights from their pupils, workers or patients. The earliest height data available starts around 1813 with the prison records of Quebec City. ${ }^{359}$ However speculative this is, the puzzle has importance. While New France exhibits deterioration in these measures of the biological standard of living, the American colonies exhibit improvements. In his work, Robert Fogel presents data on heights for native-born white American males which remained stable from 1710 to 1750 , increased to 1770 and remained stable until $1830 .{ }^{360}$ Fragmentary evidence advanced by Stanley Kunitz shows_-but not conclusively - that mortality declined in colonial New England (at the very least, it did not increase). ${ }^{361}$ Susan Norton also provides signs of stability in terms of mortality - albeit for one region of Massachusetts. ${ }^{362}$ Richard Steckel's conclusions about nutritional status in colonial America also show strongly that the living standards of Americans were probably increasing slightly. ${ }^{363}$ This is the exact opposite from New France.

\subsection{Conclusion}

The aim of this chapter was to see if any the potential pitfalls of the welfare ratios could alter the conclusion from the welfare ratios section. The use of a modified version of Altman's GDP series allowed us to see that the conclusion that Quebec did not catch up with Colonial America was reliable. In fact, our estimates of growth place New France at the bottom of a pack of slow growth areas. Although our estimates are not far from those who argue that there was very slow growth in the American colonies, when taken as part of the entire set of estimates of living standards growth between the late seventeenth century and the mid-eighteenth century, New France is at the bottom of the pack. In fact, even when compared to the lowest of low estimates for the American colonies, New France's long term performance is the worst (and suggests deterioration). Table 4.4 illustrates different sources of economic growth estimates for the American colonies and shows how lackluster was New France's level of economic growth.

\footnotetext{
${ }^{359}$ Donald Fyson, and François Fenchel. 2014. "Prison registers, their possibilities and their pitfalls: the case of local prisons in nineteenth-century Quebec." The History of the Family ahead-of-print.

${ }^{360}$ Robert Fogel. 2004. The Escape from Hunger and Premature Death, 1700-2100: Europe, America and the Third World. Cambridge: Cambridge University Press, p.17.

${ }^{361}$ Stanley Kunitz. 1984. "Mortality change in America, 1620-1920", Human Biology, Vol.56, no.3, pp.559-582.

${ }^{362}$ Susan Norton. 1971. "Population growth in colonial America: A study of Ipswich, Massachusetts", Population Studies, Vol.25, no.3, pp.433-452.

${ }^{363}$ Richard Steckel. 1999. "Nutritional Status in the Colonial American Economy", William \& Mary Quarterly, Vol.56, no.1, pp.31-52.
} 
Table 4.4. Estimates of economic growth in the United States versus New France

\begin{tabular}{ccc} 
& Period & Annual rate of growth \\
\hline Northern United States (Egnal) & $1713-1775$ & $+0.60 \%$ \\
Southern New England (Anderson) & $1700-1779$ & $+0.51 \%$ \\
All 13 colonies (Egnal) & $1713-1775$ & $+0.50 \%$ \\
All 13 colonies (Jones) & $1700-1770$ & $+0.40 \%$ \\
Southern New England (Main and Main) & $1650-1770$ & $+0.35 \%$ \\
New France & $1688-1739$ & $+0.21 \%$ \\
All 13 colonies (Mancall and Weiss) & $1700-1770$ & $+0.05 \%$ \\
New France & $1688-1762$ & $-0.10 \%$ \\
\hline
\end{tabular}

Sources: Terry L. Anderson. 1979. "Economic Growth in Colonial New England: Statistical Renaissance", Journal of Economic History, Vol.39, no.1, p.243-257; Egnal, Marc. 1998. New World Economies: The Growth of the Thirteen Colonies and Early Canada. Oxford: Oxford University Press; Alice Hanson Jones 1980. Wealth of a Nation to Be. New York: Columbia University Press; Gloria Main and Jackson Main. 1988. "Economic Growth and the Standard of Living in Southern New England, 1640-1774", Journal of Economic History, Vol. 48, no.1, pp.27-46; Mancall, Peter and Thomas Weiss. 1999. "Was Economic Growth Likely in Colonial British North America" Journal of Economic History, Vol.59, no.1, pp.17-40. Note: The methodology used in this paper is closest to that of Mancall and Weiss (which I find more convincing). The other papers used either probate records or imports per capita.

Secondly, this chapter has shown that comparisons of living standards using welfare ratios based on income rather than real wages does not affect the relative position of New France to the American colonies. It remains poorer than these colonies by a substantial margin and the extent of that gap is not affected by the choice of metric. However, the situation of New France relative to Europe deteriorates dramatically if I use real incomes. This is because the inhabitants of France or England had the option of increasing their incomes by working for longer periods of time. The climate of Canada prevented the use of this choice for French-Canadians by limiting the length of the work year. Consequently, the results presented in Chapter 4 are conservative. It also suggests that future research on comparing living standards across space during the colonial era requires not only the use of a respectable basket (rather than only a bare bones basket - see the conclusion to Chapter 4) but also a proper investigation into the length of work years between different areas.

However, these results need to be contextualized. While economic growth was disappointing in the long run, it was not the case that it was weak in peace years. Table 4.3 above showed that before the ruinous cycle of invasions and the final fall of New France to the British which began in 1740 , economic growth was positive and close to $0.21 \%$ per annum. This will be an element of discussion in the next section. On the other hand, the results presented above which compared incomes across regions are not affected by the subject of war. The data presented ended in 1740 and thus the differences presented above would have widened between 1740 and 1760 given the extent of the physical destruction the colony endured.

Finally, the brief episode of economic growth up to 1740 was not fueled by productivity growth. There may have been increases in productivity. However, substantial land clearing that led to larger farms suggests that households simply decided to use more cheap inputs like land. This episode of growth was not marked by any improvements in biological living standards since 
infant mortality and crude mortality kept increasing throughout the era and kept increasing after 1740 . 


\section{PART 5: POPUlation AND} INSTITUTIONS IN FRENCH AMERICA 


\subsection{The Initiation of Divergence}

In the previous sections of this thesis, it has been highlighted that Quebec experienced no long-term growth in living standards, as was the case in the other North American colonies surveyed here, and that the level of living standards was lower than in the American colonies. Hence, there was already a gap between French America and the rest of North America in the colonial era. By the beginning of the twentieth century, it was still lagging behind and was in fact slightly poorer than Argentina in Latin America. ${ }^{364}$ Although the province of Quebec would begin to converge with the rest of Canada after the 1940s, ${ }^{365}$ it was clearly part of a "little divergence" within North America. Given its position relative to Argentina in the late nineteenth century, it is even possible to say that up to the late nineteenth century, it diverged exactly like the rest of the Americas would relative to the United and English-Speaking Canada. The colonial origins of divergence are empirically evident. I have not attempted to tackle what the likely causes of this early divergence were. The topic of the causes of divergence would require a separate dissertation. Consequently, the current section is speculative. It merely aims to highlight possible venues for research.

From the late seventeenth century to the mid-eighteenth century, it is unlikely to find that innovation led to important growth as there was very little of it. One can safely rule out any form of "Schumpeterian growth." Important technological changes did not materialize in Quebec until the mid-1830s and onwards. At any point before that, any growth would have been "Smithian" in nature - whereby an increase in the size of markets generates economies of scales and increases the scope for specialization. In the absence of technological innovation, the expansion of markets and intensification of trade were the only remaining channels for productivity growth and economic growth. As a result, the backdrop of any discussion about the causes of New France's divergence should centre on factors allowing (or prohibiting) "Smithian growth": population growth (because of scale effects) and transaction costs.

This last part of my thesis will speculate that the overarching issue for Quebec was its small and thinly distributed population. This limited the scope for specialization, the potential for economies of scale and the ability to create trade networks. This overarching problem was likely compounded by poor institutions.

\footnotetext{
364 Morris Altman. 2003. "Staple theory and export-led growth: constructing differential growth", Australian Economic History Review, Vol.43, No.3, pp.230-255

${ }^{365}$ I have discussed this issue elsewhere: Vincent Geloso. 2013. Du Grand Rattrapage au Déclin Tranquille : Une Histoire Économique et Sociale du Québec de 1900 à nos jours. Montréal : Accent Grave ; Vincent Geloso. 2013. Une perspective historique sur la productivité et le niveau de vie des Québécois-de 1870 à nos jours. Montréal: Centre for Prosperity and Productivity at HEC Montréal. Readers should also consult Marc Egnal. 1996. Divergent Paths: How Culture and Institutions have shaped North American Growth. Oxford: Oxford University Press.
} 


\subsection{Population and growth, necessary...}

Unlike the American colonies, migration to New France was very limited and often statedirected. During the era of French rule, migration policy to New France was "confused, shortsighted and frequently contradictory." ${ }^{366}$ The main point to remember is that unlike the British, the French were reluctant to depopulate France. ${ }^{367}$ The focus of the colony was to extract furs, it was not meant as a settlement colony. ${ }^{368}$ What migration occurred was generally not free migration, but mostly waves of migration ordered by the royal administration. This is why Peter Moogk qualifies the migrants as "reluctant." 369 In total, only 2911 individuals migrated to New France between 1670 and 1729 (82.4\% of which were males). ${ }^{370}$ From 1730 to 1749 , the migration numbers did not pick up; they stayed constant meaning that an additional 1092 immigrants moved to New France. Indentured servitudes did not have a strong pull over the inhabitants of France. Although the question of why indentured servitudes did not operate like in the British colonies is an interesting question, it would push us far away from our topic. It is also crucial to point out that the quality of the migrants was not equal to that of the United States. A third of all the immigrants that came to New France as engagés (the equivalent of indentured servitude which I described in greater details in the previous essay) returned to France at the end of their contracts ${ }^{371}$ and I do not know how many left for the American colonies even though I know that it happened. Hence, the number of skilled migrants was very small. This is why the migration to New France can be considered as being of "lower quality". Those who migrated past 1720 were generally fils de famille (wayward young men) or faux-saulniers (salt smugglers). The former were generally young men who were seen as disruptive or dishonorable by their family. The families of these young individuals would purchase a lettre de cachet which was a legal order issued by the king that circumvented the formal legal system. A lettre de cachet was accompanied by severe punishment

\footnotetext{
366 James Pritchard. 2007. In Search of Empire: The French in the Americas, 1670-1730. Cambridge: Cambridge University Press, p.18. Note: The quote used from Pritchard relates to the policy adopted by minister Colbert, but the quotation applies to others as well.

${ }^{367} \mathrm{Ibid}$, p.19. Note: Pritchard underlines that Colbert and the king actually believed that France was underpopulated. ${ }^{368}$ This is often repeated in the literature. See: Josianne Paul. 2008. Exilés au nom du roi: Les fils de famille et les faux-sauniers en Nouvelle-France, 1723-1749. Montréal: Édition Septentrion, p.30; James Pritchard. 2007. In Search of Empire: The French in the Americas, 1670-1730. Cambridge: Cambridge University Press, p.18; Hubert Charbonneau, Bertrand Desjardins, Jacques Légaré and Hubert Denis. 2000. "The Population of the St-Lawrence Valley, 1608-1760", in eds. Michael Haines and Richard Steckel, A Population History of North America. Cambridge: Cambridge University Press, p.100.

${ }^{369}$ Peter Moogk. 1989. "Reluctant Exiles: Emigrants from France in Canada before 1760", William \& Mary Quarterly, Vol.46, No.3, pp.463-505.

${ }^{370}$ Hubert Charbonneau and Normand Robert. 1987. "The French Origins of the Canadian Population, 1608-1759" in eds. Richard Harris, The Historical Atlas of Canada, Vol.1, Toronto: Toronto University Press, plate 45. This can also be found in Hubert Charbonneau and Normand Robert. 1998. "The French Origins of the Canadian Population, 16081759" in eds. William Dean, Conrad Heidenreich, Thomas Mcllwraith and John Warkentin, The Concise Historical Atlas of Canada. Toronto : Toronto University Press, plate 34.

371 Marcel Trudel 1997. Histoire de la Nouvelle-France, Vol.IV: La Seigneurie de la Compagnie des Indes Occidentales, 1663-1674. Montreal: Éditions Fidès, p. 306.
} 
(repossession or hanging) or, in our case, deportation to New France. Between 3\% and 7\% of migrants to New France between 1720 and 1760 (migrated in this manner and they were migrants who had a very hard time integrating within colonial society. ${ }^{372}$ As for the faux-saulniers, they were salt smugglers who got caught. A total of 607 of them were deported to Quebec between 1730 and 1749 - more than half of the migration during that period. ${ }^{373}$ These individuals were mostly used to settle distant areas like those around Detroit and their behaviour was problematic as they often deserted from their indentures. ${ }^{374}$ It was often complained that the government in France did not send the best migrants as some were seen as physically weak or unfit for work to the point that the colonial administrator requested that no more idiots, cripples, chronically ill and wayward young men be sent in the future. ${ }^{375}$

\footnotetext{
372 The figure of 7\% comes from the work of Josianne Paul. 2008. Exilés au nom du roi: Les fils de famille et les fauxsauniers en Nouvelle-France, 1723-1749. Montréal: Édition Septentrion, p.70. Paul extrapolated this data from the estimates of Mario Boleda. 1983. Les Migrations au Canada sous le régime Français. $\mathrm{PhD}$ thesis, department of History at the Université de Montréal. However, her raw number of 84 fils de famille combined with the more recent estimate produced Hubert Charbonneau and Normand Robert (1998. "The French Origins of the Canadian Population, 1608-1759" in eds. William Dean, Conrad Heidenreich, Thomas Mcllwraith and John Warkentin, The Concise Historical Atlas of Canada. Toronto: Toronto University Press, plate 34) shows that the proportion is closer to 3\%.

373 Josianne Paul. 2008. Exilés au nom du roi: Les fils de famille et les faux-sauniers en Nouvelle-France, 1723-1749. Montréal: Édition Septentrion, p.126. I have used the raw figure proposed by Paul and combined it the migration estimates of Charbonneau and Robert (see previous footnote).

${ }^{374}$ Ibid, p.157-161.

${ }^{375}$ Peter Moogk. 1989. "Reluctant Exiles: Emigrants from France in Canada before 1760”, William \& Mary Quarterly, Vol.46, No.3, p.466 and p.480.
} 
Figure 5.1. Population of New France, Massachusetts and Pennsylvania

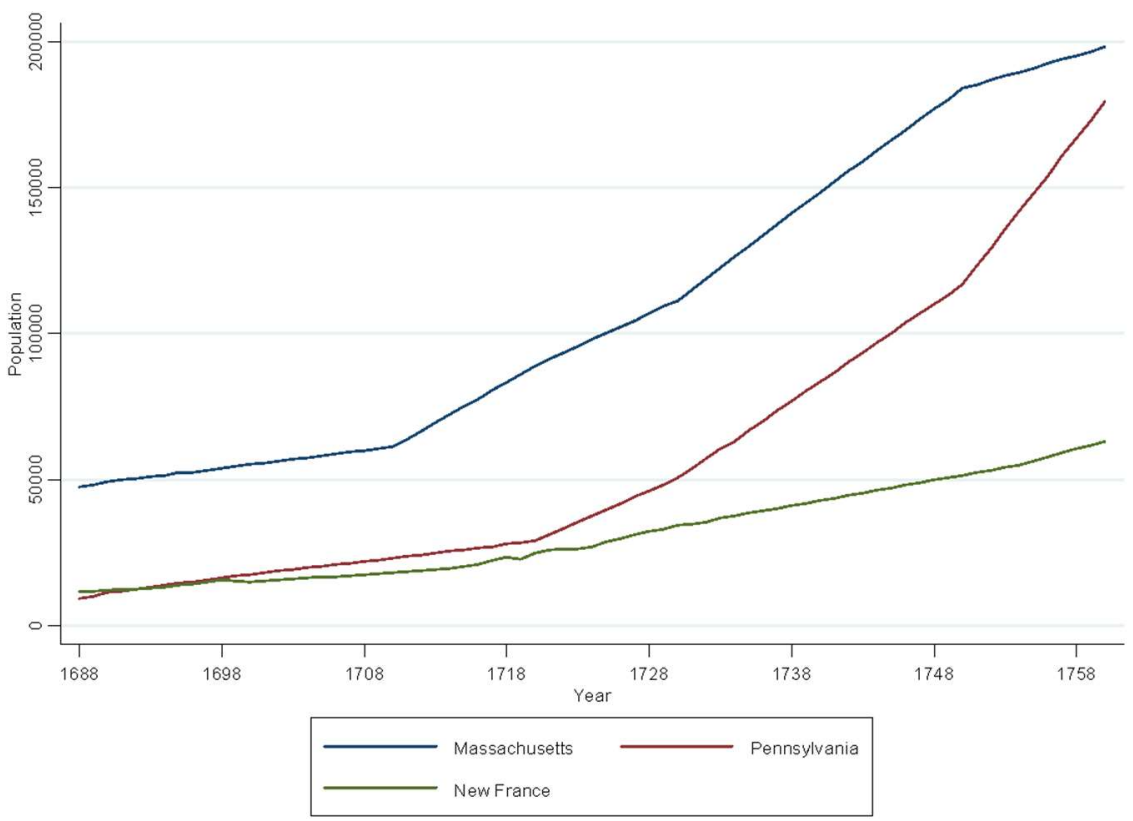

Source: For the British colonies, I have relied on Alvin Rabushka's appendix which details the American population at the time. Alvin Rabushka. 2008. Taxation in colonial America. Princeton: Princeton university press, pp.872-888. For New France, I have used the population data contained in Richard Lalou and Mario Boleda. 1988. "Une source en friche : les dénombrements sous le Régime français", Revue d'histoire de l'Amérique française, Vol.42, no.1, pp.47-72 and Public Archives of Canada. 1876. Census of 1871, vol. IV. Ottawa: Department of Agriculture.

Figure 5.2. Population of New France as share of that of the thirteen colonies

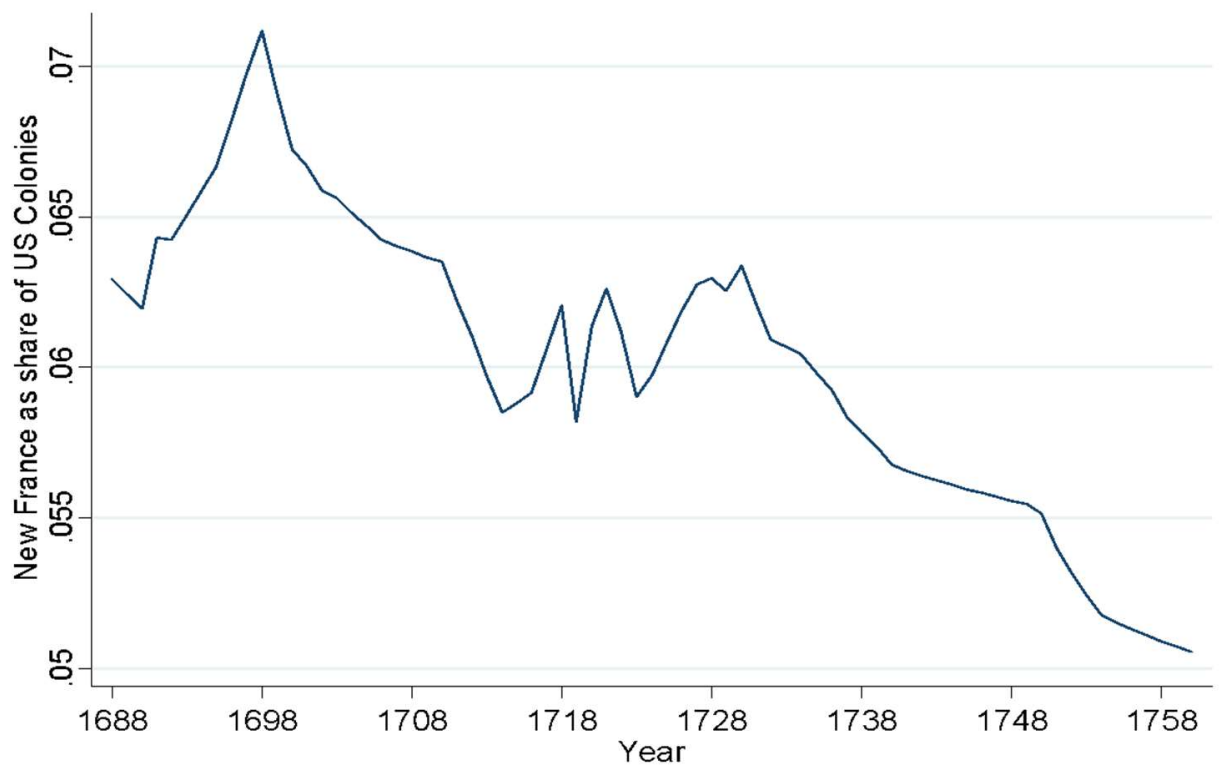


Consequently, most of the population growth — although it was very fast - would have come from natural increases. Moreover, the level of population was still very small. As Figure 5.1 can testify, French America was a mere fraction of individual colonies like Massachusetts and Pennsylvania. This slower rate of population growth can also be better seen in Figure 5.2 where the population of New France is represented as a share of the total population of the thirteen colonies - a share that declines from roughly $6.5 \%$ in the late seventeenth century to close to $5 \%$ when the British conquered Quebec.

There are numerous channels through which growth could have been affected by the level of population. They are not mutually exclusive and disentangling them would require a dissertation in itself. Given the traits of this migrant population, I can speculate about a first possible cause for initial divergence. Ran Abramitzky and Fabio Braggion used servants' contracts in the seventeenth and eighteenth centuries to show that the migrants to the American colonial mainland were chosen based on their human capital endowments. Individuals endowed with more human capital were prone to favor the American colonies rather than the West Indies. Differences in relative human capital endowments at the outset would have explained the divergence that occurred afterwards between the Caribbean and colonial America. ${ }^{376}$ In their opinion, not only would a difference in human capital endowments have contributed to differences in paths of growth, but it would also have affected institutional quality which would accentuate the differences in growth paths. ${ }^{377}$ However, this venue should be used carefully. The reluctance of French migrants to move to New France was the result of numerous factors - many of them institutional. True, the harsh climatic conditions of violent Canada (conflicts with the Indians were frequent and violent) ${ }^{378}$ would deter migrants. Nonetheless, numerous governmental regulations in New France made migration less attractive to migrants. ${ }^{379}$ This would be combined with efforts by the French government itself to disfavor migration. In addition, the "pull" of the colony would have been greater living standards than what could be obtained in France. The fact that this "pull" had limited strength because the

\footnotetext{
${ }^{376}$ Ran Abramitzky et Fabio Braggion. 2006. "Migration and Human: Self-Selection of Indentured Servants to the Americas", Journal of Economic History, Vol.66, no.4, pp.882-905.

377 Edward Glaeser, Rafael La Porta, Florencio Lopez-de-Silanes and Andrei Shleifer. 2004. "Do institutions cause growth?", Journal of Economic Growth, Vol.9, no.3, pp.271-303.

378 Serge Couville. 2008. Quebec: A Historical Geography. Vancouver: University of British Columbia Press, p.73. The reluctance to migrate can be well seen in the attempts of the Versailles government to force ship-owners to carry labourers to Canada in proportion to their size. Unwilling to ship migrants to start with, ship-owners refused and evaded the law by presenting fake emigrants who would disappear before the ship set sail (Adam Shortt. 1913. "The Colony in its economic relations" in Canada and its provinces: a history of the Canadian people and their institutions by one hundred associates, vol.2, edited by Adam Shortt and Arthur Doughty, Edinburgh University Press, p.480).

${ }^{379}$ For example, settlers were prohibited from engaging in the lucrative fur trade. A seventeenth century regulation prohibited French Canadians to "leave their homes and wandering into the woods for longer than twenty-four hours without special permission from the government". (Adam Shortt. 1913. "The Colony in its economic relations" in Canada and its provinces: a history of the Canadian people and their institutions by one hundred associates, vol.2, edited by Adam Shortt and Arthur Doughty, Edinburgh University Press, p.473). The fur trade was reserved for the monopolistic crown corporation entitled with the exports of pelts to France.
} 
gap in living standards was very small also explains why French households would be reluctant to leave to New France. However, I must then explain why relative living standards between France and New France were as they were. Future research could attempt to assert how differences in human capital played in, but the migration of individuals with human capital still needs to be explained.

Another channel would be that, under "Smithian growth," the size of populations could generate scale effects. Basically, a larger population implies a greater market, hence greater economies of scale and scope for specialization. ${ }^{380}$ However, in the absence of technological innovation, population growth can only go as far as the limited pool of resources allows it. Eventually, diminishing returns will start reducing the pace of growth. At first, this problem does not seem considerable. Arable lands were abundant and could easily be exploited. ${ }^{381}$ Although researchers debate whether or not economic growth was slightly positive or non-existent during the colonial era, no one argues that there was a long-term decline in living standards in colonial America. ${ }^{382}$ This is in spite of a considerable increase in population whose levels were many times above those of New France. Sustaining rapid population growth in combination with stable or increasing living standards is suggestive of the view "that the high rate of population growth was also transformed into a high rate of growth of gross domestic product". ${ }^{383}$ One could argue that population size did not matter given the amount of idle resources.

The channel through which population growth could offset the pressures of population size relates to trade networks. Larger population allows for economies of scale in creating information networks - once the initial investment of creating the network is realized and the marginal cost is low, there are important returns to scale. ${ }^{384}$ Such social networks permit greater cooperation between individuals as information circulates more easily with regard to market opportunities that could be exploited. ${ }^{385}$ This can be well seen in the negative with the case of Spain after the black

\footnotetext{
380 Kelly Morgan. 1997. "The Dynamics of Smithian Growth”, Quarterly Journal of Economics, Vol.112, No.3, pp.939-964.

${ }^{381}$ Morris Altman pointed out that in the last years of French rule, less than $9 \%$ of all land granted in New France had been improved and used for agriculture when the population stood above 60,000. (1983. "Seigniorial Tenure in New France, 1688-1739: An Essay on Income Distribution and Retarded Economic Development". Historical Reflections / Réflexions historiques, Vol.10, No.3, pp.335-375).

382 Joshua Rosenbloom and Thomas Weiss. 2012. "Economic Growth in the Mid-Atlantic region: Conjectural estimates for 1720 to 1800”, Explorations in Economic History, Vol.51, No.1, pp.41-59; Peter Mancall and Thomas Weiss. 1999. "Was economic growth likely in British North America?", Journal of Economic History, Vol.59, No.1, pp.17-40; Alice Hanson Jones. 1980. Wealth of a Nation to Be. New York, NY: Columbia University Press; Marc Egnal. 1998. New World Economies. Oxford: Oxford University Press; Peter Lindert and Jeffrey Williamson. 2014. American Colonial Incomes, 1650-1774. Cambridge, MA: National Bureau of Economic Research,

383 Joshua Rosenbloom and Thomas Weiss. 2012. "Economic Growth in the Mid-Atlantic region: Conjectural estimates for 1720 to 1800”, Explorations in Economic History, Vol.51, No.1, pp.42.

${ }^{384}$ Leonard Dudley. 2008. Information Revolutions in the History of the West. London: Edward Elgar Publishing.

385 Leonard Dudley. 2012. Mothers of Innovation: How Expanding Social Networks Gave Birth to the Industrial Revolution. Newcastle upon Tyne: Cambridge Scholars Publishing.
} 
death. Àlvarez-Nogal and Prados de la Escosura argued that at the time of the black death, Spain was a frontier economy with more abundant land. The plague did not reduce pressures on scarce land resources; it merely eradicated commercial networks, isolated scarce populations and led to a decline in specialization. ${ }^{386}$ This line of argument has been often used in discussions of Quebec's economic history in the early nineteenth century, by Serge Courville on the one hand and JeanPierre Wallot and Gilles Paquet on the other. ${ }^{387}$ Their argument was that the rapid population growth of the early nineteenth century, combined with a trend in favour of urbanization, created markets for farmers to satisfy. Through this population growth, marginal farmers shifted inputs away from agriculture and worked in the lumber industry. In short, the larger population - in the context of abundant resources_-permitted the creation of new markets so that specialization became possible.

This element is reminiscent of the argument advanced in the works of Ester Boserup ${ }^{388}$ and Julian Simon. ${ }^{389}$ These authors advanced that a greater population meant increasing rather than diminishing returns. Greater population density renders numerous investments more profitable. Moreover, a larger population means also a greater circulation of ideas. This latter point is probably the most important and refers to a debated literature in economics that concerns "scale effects." Scale effects arise when ideas (read: information) are non-rival inputs in the production of intermediate goods needed to generate final products. As population increases, more and more inputs are cheaply made available for intermediate production.

This is where the advantage of the American colonies can be best seen. Thanks to their size and access to the British market, the Americans had the possibility of harnessing important economies of scale and becoming part of an important trading network. In addition, when wars rendered trade difficult and risky, the Americans had an large domestic market to rely upon. This was not the case for New France. Contrary to the American colonists who could trade with other colonies, the French had a very limited trading network. Trade was limited within the boundaries of New France, the neighbouring colony of Acadia with a population of less than $10,000^{390}$ and the French West Indies. The colonists of New France enjoyed fewer economies of scale than the Americans in peacetime as a result of the size of the population-a problem which was

\footnotetext{
${ }^{386}$ Carlos Álvarez-Nogal, and Leandro Prados De La Escosura. 2013. "The rise and fall of Spain (1270-1850)", Economic History Review, Vol.66, No.1, pp.1-37.

${ }^{387}$ Serge Courville. 1990. Entre Ville et Campagne : l'essor du village dans les seigneuries du Bas-Canada. Québec : Presses de l'Université Laval ; Gilles Paquet and Jean-Pierre Wallot. 2007. Un Québec Moderne, 1760-1840 : Essai d'histoire économique et sociale. Montréal : Éditions HMH.

${ }^{388}$ Ester Boserup. 1965[2008]. The Conditions of Agricultural Growth: The Economics of Agrarian Change under Population Pressure. New Brunswick, NJ: Aldine Transactions.

389 Julian L. Simon. 1977. The Economics of Population Growth. Princeton, NJ: Princeton University Press.

${ }^{390}$ This colony would be ceded to the British in 1713 although it always had a special situation whereby the inhabitants declared themselves as "Neutrals" and traded very little with New France-see Vincent Geloso. 2015. "Toleration and British Public Finances in Quebec, 1760-1775", Essays in Economic and Business History, Vol.33, pp.51-80.
} 
compounded by government policies. Early and often, the intendants of New France enacted prohibitions on trading with the American colonists. For example, in 1699, the colonial government prohibited the use of hard money in the trade with American colonists. ${ }^{391}$ An attempt to establish a trade agreement with New England was refused by the colonial government. ${ }^{392}$ There were large smuggling endeavours on the part of French colonists to the American colonies to evade such regulations. But this should not be overstated since the bulk of smugglers were engaged in the fur trade. ${ }^{393}$ Only a small share of New France's population was actively involved in this sector of employment. In effect, these restrictions on trade virtually limited the effective size of the market for French-Canadian products. In addition to barriers to international trade, the colony was also saddled with numerous interventions in the domestic market which prevented integration between the different regions of the colony. The intendants would frequently prohibit exports, seize harvests to store the military reserves and enact price controls that hindered trade. ${ }^{394}$ Undeveloped trading networks would have greatly amplified the problems of a small population. In addition, it is likely that intermittent warfare would have damaged New France's economy more than that of the thirteen colonies. While the American colonists would have also been affected by wars that would disrupt trade, the size of their domestic market would make the shock less pronounced than in New France. In times of war, the size of the market for New France would shrink to a few tens of thousands of individuals - even if the other settlements in New Brunswick were included. By comparison, Massachusetts alone would have had a market comprising above a hundred thousand of individuals (190,000 by 1760). Intermittent warfare would thus have asymmetric effects on the colonies in North America with greater pain for the French colonists. ${ }^{395}$ The evidence collected in Chapters 4 and 5 confirms this reality. In peaceful years, economic growth in the French colony was positive and living standards were at relatively higher levels (although not high enough to close the gap with the American colonies). Each time the colony was engulfed in war or was just plain invaded, growth stopped and living standards plunged dramatically. In fact, this can easily be explained by thinking of a small open economy model in international trade. Wars cause trade shocks, trade shocks lead to income shocks and recessions.

\footnotetext{
${ }^{391}$ Adam Shortt. 1925. Documents Relating Canadian Currency, Exchange and Finance During the French Period, Selected and Edited with Notes and Introduction, Volume 1, Ottawa: Board of Historical Publications Canadian Archives, p.109.

392 Adam Shortt. 1913. "The Colony in its economic relations" in Canada and its provinces: a history of the Canadian people and their institutions by one hundred associates, vol.2, edited by Adam Shortt and Arthur Doughty, Edinburgh University Press, p.457.

${ }^{393}$ Alice Jean Lunn. 1939. “The Illegal Fur Trade out of New France, 1713-1760”, Report of the Annual Meeting of the Canadian Historical Association, Vol.18, no.1, pp.61-76.

${ }^{394}$ Louise Dechêne.1994. Le Partage des Subsistances au Canada sous le Régime Français. Montréal: Éditions Boréal.

${ }^{395}$ This point is largely inspired from Dani Rodrik. 1988. "Imperfect Competition, Scale Economies, and Trade Policy in Developing Countries", in Trade Policy Issues and Empirical Analysis, edited by Robert Baldwin, Chicago IL: University of Chicago Press, pp.109-144.
} 
In addition, its links to trading partners were not as secure as those of the American colonies. From 1688 to 1760 , the relative strength of the French royal navy-supposed to protect the merchant fleet - diminished progressively. By the time of the conquest in 1760, there were more than two British ships of the line for each French ship of the line (see Figure 5.3). Hence, the size of the population of New France would have meant limited economies of scale in peace years and greater vulnerability to trade shocks caused by wars.

Figure 5.3. Ratio of French to British ships of the line, 1688 to 1760

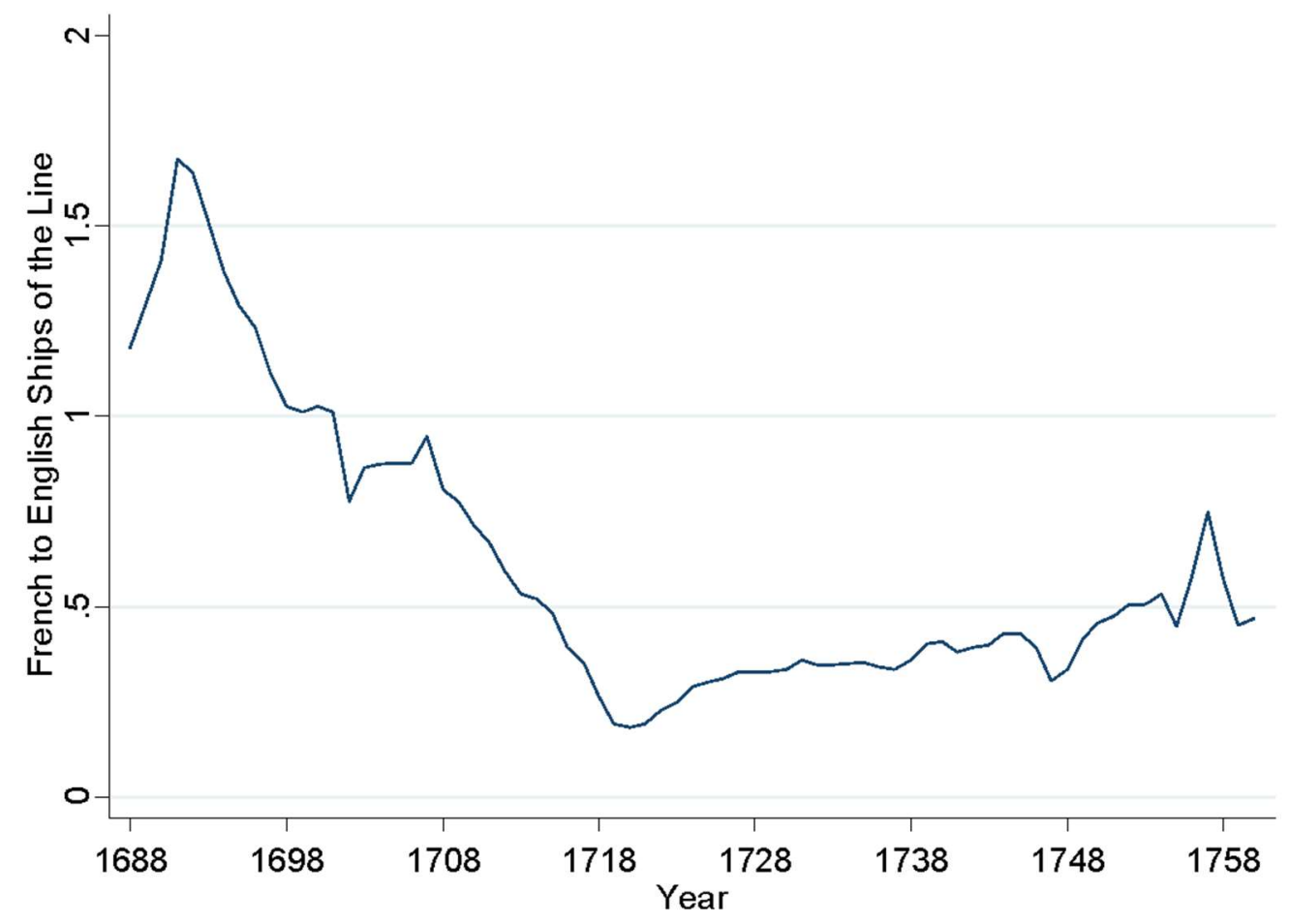

Source: George Modelski and William Thompson., 1988. Seapower in global politics, 1494-1993. Seattle, WA: The University of Washington Press.

Nevertheless, speculations about population size should bear in mind that while it may be a necessary factor to explain New France's performance, it is by no means sufficient. The case of Australia is quite illustrative in that regard. In 1800, Australia had close to 6,000 white settlers and 30,000 by 1820 . Yet, it experienced fast economic growth, reaching high levels of living standards. ${ }^{396}$ Moreover, Australia was much farther away from the mother country than New France was from hers. Economic growth in the context of this small population, in combination to its relative isolation, suggests that population size is not sufficient.

\footnotetext{
${ }^{396}$ Ian McLean. 2013. Why Australia Prospered: The Shifting Sources of Economic Growth. Princeton NJ: Princeton University Press, p.15.
} 
Speculations about the effects of population size on economic growth were linked to the Smithian argument that larger populations meant greater scope for specialization and larger economies of scale. However, Smithian growth could also occur through lower transaction costs which would improve allocative efficiency. The literature on scale effects as a result of population growth is hotly contested. Its underlying implication is that populous economies should grow faster than smaller ones. This has led many economists to deride the concept, ${ }^{397}$ especially since the data does not support this conclusion. ${ }^{398}$ However, the idea should not be discarded as Lewis Davis points out that population is a poor proxy variable for ideas. ${ }^{399}$ Davis argues that, out of analytical convenience, population size was used as the proxy for non-rival information that could support expansion in trade. If transaction costs are falling while there is a stable population level, Davis argues that the "potential for exploiting non-rival ideas has grown much faster than (...) population size". ${ }^{400}$ Hence, as population increases, there can be scale effects as long as transaction costs do not increase so as to offset the scale benefits. In his article, Davis argued that the level of scale effects was dependent on transaction costs which were in turn dependent on institutions which may create, increase or reduce transaction costs. The level of transaction costs depends on institutional features that govern the economy. Hence, the size of the population can be a good proxy for non-rivalrous ideas in the case of a closed economy, like New France was, but transaction costs imposed by institutions could compound the problem. Fruitful research could be accomplished by investigating institutional arrangements that could have compounded the problem of small population size. One very likely candidate is seigneurial tenure.

\section{3. ...but insufficient without considering seigneurial tenure}

In the economic history of Quebec, one institution has been the subject of numerous debates: the system of seigneurial tenure. Imported from France, under seigneurial law a landlord would buy a landed estate from the crown, and with that acquisition was associated some obligations. The landlord (seigneur) was required to grant (freely) land to peasants which would become censitaires. The censitaires would pay the seigneur a rent for the acquisition and use of the land granted which were called cens et rentes. These rates were established in relation to land held rather than the amount of land actually farmed (they could be legally construed as taxes on assets

\footnotetext{
${ }^{397}$ Robert Lucas. 1993. "Making a miracle”, Econometrica. Vol.61, no.2, pp.263.

398 Charles Jones. 1995. "Time Series Tests of Endogenous Growth Models", Quarterly Journal of Economics, Vol.110, No.2, pp.495-525. Joel Mokyr offered a more mixed view pointing out "such scale effects may clash with the economist's intuition of diminishing returns, but up to some at least there are fixed costs and indivisibilities such as roads, schools, property-rights enforcement agencies, and so on, which can be deployed effectively only for large populations": Joel Mokyr. 1990. Twenty-Five Centuries of Technological Change. London: Routledge Publishing, p.2.

399 Lewis Davis. 2008. "Scale effects in growth: A role for institutions", Journal of Economic Behavior \& Organization, Vol.66, No. 2, 403-419.

${ }^{400} \mathrm{Ibid}, \mathrm{p} .417$.
} 
rather than output). The peasant was not allowed to leave his farmstead. He was obligated to either cede the farm to his family and then settle elsewhere or sell his farm to a buyer. He could not simply abandon his plot and move.

In return, the seigneur would have to provide grist mills to the peasants (he was obligated to do so but rarely did since close to half of all seigneuries had no mills by 1739) ${ }^{401}$ and he was only allowed (by royal edict) to charge one fourteenth of the grains brought to the mill to be turned into flour (this was known as the banalité). The peasant was not allowed to use grist mills in neighbouring seigneuries. Other obligations would be associated such as that of the corvée in which the peasants would have to do work for the seigneur on certain days (generally three days or sixty sols per day if he decided not to work). The censitaire was also subjected to the lods et ventes which required he pay an $8.5 \%$ tax to the seigneur upon selling his land. The seigneur himself was obligated to pay the quint which was also a tax to be paid upon selling the estate, but he would pay this to the crown. There were other minor obligations, but they are not of relevance to our story here. To all of these were added the dime - a religious tithe charged by the church who generally also wore the hat of seigneur at the same time. The tithe represented one twenty-sixth of gross grain output. Unlike the cens et rentes, the dime applied to output rather than assets. Finally, the seigneur had monopoly right on the establishment of mills and access to waterways. Moreover, the seigneur had the right to tax everyone on his estate which acted as a tax on such activities. Generally, seigneurs would be active in numerous forms of investments from the flour mill to the saw mill.

In the face of economic theory, it is hard to see how seigneurial tenure could have helped. It contained elements of predatory taxation (taxes being received against very little public good provision), monopolies, price controls, taxes on capital assets and restrictions on mobility. However, saying that it did not help does not tell us anything about the amplitude of the detrimental effects. Obviously, this institution puts New France in a category of its own relative to New England which had very different institutional settings.

The problem is that it would be very complicated to create strong tests to assess the importance of seigneurial tenure in explaining differences in living standards between New France and the American colonies. Indeed, all of New France was settled as seigneuries meaning that I would have nothing to benchmark against. One could use New England to study institutional features and their relative importance. The problem is that the data for New England is scant and much poorer in terms of quality than that of New France. Furthermore, any test between colonial New England and New France would run into complaints of geographical and cultural

\footnotetext{
401 Morris Altman. 1983. "Seigniorial Tenure in New France, 1688-1739: An Essay on Income Distribution and Retarded Economic Development”. Historical Reflections / Réflexions historiques, Vol.10, No.3, p.364
} 
comparability. As a result, any effort to ascribe a role to seigneurial tenure would be a considerable empirical challenge. However, there is a way that future researchers (I do not intend to undertake this issue here, I merely aim at presenting such a viable channel for research) can circumvent the issue. After the conquest in 1760, the British maintained the institution. With the constitutional act of 1791, the British opted to allow all new settlements to occur under British freehold tenure law. Seigneurial law would remain in place where it was already established. The newly settled areas would be legally known as townships rather than parishes. This legal condition creates a powerful natural experiment. Individuals could - under the constraints of assuming the costs of resettling and land clearing - choose between different institutional regimes. Differences in outcomes between such areas could be exploited if proper controls are introduced to measure the role of land tenure laws.

As a result, assessing the causes of French Canada's divergence could be an easier task if I moved forward in time to the era of British rule to exploit this natural experiment. Assessing the presence of differences in outcomes at that later time would indicate the relevance of using this experiment as a research tool.

Traditional sources (henceforth designed as the "traditionalist" view of seigneurial tenure) view this peculiar institution as the main culprit of Quebec's poor performance. This viewpoint can be further subdivided into two: a) seigneurial tenure hindered agricultural productivity growth or b) seigneurial tenure hindered the emergence of non-farm industries. Broadly speaking, the "traditionalist" view was the dominant one until the mid-twentieth century. ${ }^{402}$ Starting in the nineteenth century, the greatest emphasis of the adverse effects of the system centered on the claim that it limited capital accumulation for peasant households. ${ }^{403}$ Farm households operating under seigneurial law - after decades of underinvestment - exhibited lower levels of productivity than farm households operating under British law. ${ }^{404}$ Richard Harris estimated seigneurial dues somewhere between $5 \%$ and $10 \%$ of the average farm household income and Louise Dechêne, on the other hand, considered that they absorbed up to $14 \%$ of the average household income. ${ }^{405}$ However, both authors relied on hypothetical scenarios based only on gross output. This problem was solved partially in the works of Morris Altman who took the opportunity to propose a second, more potent channel through which seigneurial tenure slowed down growth. In 1983, Altman used census data to estimate that seigneurial dues absorbed between $37 \%$ and $47 \%$ of net output per

\footnotetext{
402 Arthur Lower. 1946 [1957]. Colony to Nation: A History of Canada. Toronto, London and New York: Longmans, Green \& Company.

${ }^{403}$ Allan Greer expounds this view best in his 1985. Peasant, Lord and Merchant, Rural Society in Three Quebec Parishes, 1740-1840. Toronto: University of Toronto Press.

${ }^{404}$ Paul Philipps. 1974. "Land Tenure and Economic Development: a comparison of Upper and Lower Canada", Journal of Canadian Studies, Vol. 9, No.2, pp.35-45.

${ }^{405}$ Richard Harris. 1966 [1984]. The Seigneurial System in Early Canada. Montréal : McGill-Queen's University ; Louise Dechêne. 1974. Habitants et Marchands de Montréal au XVIIe siècle. Paris: Plon.
} 
household (measured in minots of wheat minus consumption needs and seed requirements) in the 1688-1714 period. By 1726-1739, it had declined to a share ranging between $26 \%$ and $37 \%$. ${ }^{406}$ Alan Greer, in his seminal Peasant, Lord and Merchant, estimated that feudal exactions represented $44 \%$ of the wheat surplus produced by farm households in St-Ours (on the south shore of Montreal) in $1765 .{ }^{407}$ In 1987, Altman revised his estimates downwards by half as a result of new data on seed requirements, but the costs to farm households was still considerable. ${ }^{408}$ After these calculations, Altman proposed a variation on the traditionalist view. His reasoning was that this transfer from peasants to seigneurs reduced the disposable income of peasants. This smaller surplus meant that the market for non-agricultural goods was smaller and hence the scope for specialization was reduced. ${ }^{409}$ Even if the seigneurs gained a large income, they did not represent a great pool of potential consumers for new industries. As a result, Altman argues that it limited the capacity of the economy to diversify. In essence, Altman's argument was a demand-side argument whereby lower income for the vast majority led to lower demand for non-farm goods which meant slower growth. This argument has failed to convince as there are few citations of his work by historians of early Canada and Quebec.

The other point of view found in the literature can be labelled as "revisionist" although it is not a united body of explanations. This body of literature has come to dominate the field since the mid-twentieth century. In general, it claims that seigneurial tenure did not hinder growth and was largely inconsequential. While the traditionalist view emphasized that peasants under seigneurial tenure were "unfree" labor, the revisionist Peter Russell argues that "peasants would have laughed at the notion that they were unfree labor". ${ }^{410}$ Responding to Phillips (quoted above) Russell added that the "contention that 'an abundance of cheap and free land relative to labor encourages unfree (...) labor institutions' is itself laughable."411 Although Russell in no way denies the problems associated with seigneurial tenure, he does not consider its burden as a reasonable explanation of the economic retardation of French Canada. Serge Courville argued that the seigneurs were very aggressive capitalists who developed several industries within their estates. Although he is careful not to negate the perverse sides of seigneurial tenure, Courville's argument is that the presence of

\footnotetext{
${ }^{406}$ Morris Altman. 1983. "Seigniorial Tenure in New France, 1688-1739: An Essay on Income Distribution and Retarded Economic Development". Historical Reflections / Réflexions historiques, Vol.10, No.3, pp.335-375.

${ }^{407}$ Allan Greer. 1985. Peasant, Lord and Merchant, Rural Society in Three Quebec Parishes, 1740-1840. Toronto: University of Toronto Press, p.136.

${ }^{408}$ Morris Altman. 1987. "Note on the Economic Burden of the Seigniorial System in New France, 1688-1730". Historical Reflections / Réflexions historiques, Vol.14, No.1, pp.135-142.

${ }^{409}$ Morris Altman. 1983. "Seigniorial Tenure in New France, 1688-1739: An Essay on Income Distribution and Retarded Economic Development". Historical Reflections / Réflexions historiques, Vol.10, No.3, pp.335-375, note 111 on page 374.

${ }^{410}$ Peter Russell. 2012. How Agriculture Made Canada: Farming in the Nineteenth Century. Montreal and Kingston: McGill-Queen's University Press, p.83

${ }^{411}$ Ibid, p.83.
} 
such perverse effects does not necessarily imply that they were large and significant. ${ }^{412}$ In his eyes, seigneurial tenure did not hinder investment overall. In a case study of a religious congregation in Montreal, Brian Young argued that under seigneurial tenure, the congregation he studied became a capitalistic enterprise that acted like any modern firm would. ${ }^{413}$ In his study of the seigneurie in the upper Richelieu area (south shore of Montreal), Françoise Noël asserted that the effects of the monopolies established by seigneurial tenure were not important until 1815. In fact, she argues they promoted development. ${ }^{414}$

The best summary available for the "revisionist viewpoint" is that of Percy and Szostak where they study the abolition of seigneurial tenure and state that "the negative effects of seigneurial tenure on the economy appear to have been exaggerated". ${ }^{415}$ To support this claim, they point to papers by Marvin McInnis and Frank Lewis ${ }^{416}$ who showed very small differences in total factor productivities across ethnic lines with the census of 1851 of Canada East (as Quebec was then known) which Percy and Szostak assume extends along institutional lines. According to Percy and Szostak, "the only factor likely to impinge on investment was the lods et ventes" because it would hinder capital accumulation. ${ }^{417}$ And even there, they argue it would have been small. Overall, the revisionists have the upper hand. However, they have not marshalled sufficient evidence to lay the other viewpoint to rest. In fact, the evidence suggests that the differences in outcomes have been significantly downplayed and that the "traditionalist" viewpoint has value.

\subsection{Reconsidering seigneurial tenure}

There are problems with the revisionist characterization of seigneurial tenure as having small or inconsequential effects. Percy and Szostak relied mostly on McInnis and Lewis to make the claim that the effects were small. The McInnis and Lewis papers do show some small differences whereby for all their districts, there is gap ranging from a $7.6 \%$ disadvantage to a $15.7 \%$ disadvantage over all regions in terms of TFP. There are also massive differences in partial factor

\footnotetext{
${ }^{412}$ Serge Courville. 1990. Entre Ville et Campagne : L'Essor du Village dans les Seigneuries du Bas-Canada. Québec: Presses de l'Université Laval.

${ }^{413}$ Brian Young. 1986. In its corporate capacity: The Seminary of Montreal as a Business Institution, 1816-1876. Montreal and Kingston: McGill-Queen's University Press.

${ }^{414}$ Françoise Noël. 1992. Christie Seigneuries: Estate Management and Settlement in the Upper Richelieu Valley, 1760-1854. Montreal and Kingston: McGill-Queen's University Press, p. 49.

${ }^{415}$ Michael Percy and Rick Szostak. 1992. "The Political Economy of the Abolition of Seigneurial Tenure in Canada East”, Explorations in Economic History, Vol.29, no.1, p.56.

${ }^{416}$ Frank Lewis and Marvin McInnis. 1980. "The Efficiency of the French-Canadian Farmer in the Nineteenth Century”, Journal of Economic History, Vol.40, No.3, pp.497-514; Frank D. Lewis and Marvin McInnis. 1984. "Agricultural Output and Efficiency in Lower Canada, 1851", Research in Economic History, Vol.9, p.45-88.

${ }^{417}$ Michael Percy and Rick Szostak. 1992. "The Political Economy of the Abolition of Seigneurial Tenure in Canada East”, Explorations in Economic History, Vol.29, no.1, p.57.
} 
productivity (where labor productivity was much lower in French areas than English areas). Moreover, these differences are likely quite understated.

Morris Altman rejected their results using different methods of computing output. First of all, there is a need to understand that French and English farmers used different volume and area measurements - something which the census enumerators did not necessarily correct for. The vast majority of the population - the French-speaking Catholics - used a measuring system whereby surface and volume were denominated in arpents and minots. Each arpent was equivalent to 0.845 acres and each minot was worth 1.107 bushels. Hence, one minot per arpent was $30 \%$ more than one bushel per acre. McInnis and Lewis had corrected their estimates based on county-level adjustments. ${ }^{418}$ Assuming that the corrections had to be made along linguistic lines, Altman remade the Lewis and McInnis computations by weighing the corrections by the share of population that was French-Canadian. This adjustment contributed to finding larger productivity differences. These gaps were significantly larger than those found by McInnis and Lewis, but they relied on partial productivity measurements. ${ }^{419}$

Robert Armstrong on the other hand pointed out that McInnis and Lewis had used prices which were equal throughout the colony - a fact that would have eclipsed some of the large price variations between regions due to geographic distance from key urban markets. ${ }^{420}$ Armstrong also faulted McInnis and Lewis for selecting a non-random sample of areas from 1851 census which would have driven their result. Overall, the differences have been downplayed and should not have been.

At this point, readers should be aware that my aim is not to provide a definitive answer to the importance of seigneurial tenure. Rather, my aim is to provide support for reopening the issue. I am by no means asserting that the evidence I will present below is conclusive. However, I am stating that my explanation regarding population growth is largely insufficient even if it is necessary. My belief is that seigneurial tenure could possibly complete this story.

\footnotetext{
${ }^{418}$ Marvin McInnis. 1981. "Some Pitfalls in the 1851-1852 Census of Agriculture of Lower Canada." Histoire sociale/Social History, No.27, pp.219-231; Richard Thibeault. 1989.. "Note de Recherche : Les unités de mesure dans les documents officiels du dix-neuvième siècle au Bas-Canada et au Québec.", Revue d'histoire de l'Amérique française, Vol.43, pp.221-232. For the 1831 census, the list of county-level adjustments to be made are found in Serge Courville, Jean-Claude Robert and Normand Séguin. 1995. Le pays laurentien au XIXe siècle: les morphologies de base. Québec : Les Presses de l'Université Laval.

${ }^{419}$ Morris Altman. 1998. "Land Tenure, Ethnicity, and the Condition of Agricultural Income and Productivity in MidNineteenth-Century Quebec", Agricultural History, Vol.72, No.4, pp. 708-762.

${ }^{420}$ Robert Armstrong. 1984. "The Efficiency of Quebec Farmers in 1851", Histoire sociale / Social History, Vol.17, no.33, pp.149-163.
} 


\subsection{Evidence supporting the reconsideration of seigneurial tenure}

The Constitutional Act of 1791 offers an opportunity to study differences emerging along institutional lines. After the passage of this act, French seigneurial tenure would cohabit alongside English freehold tenure. The areas under French law were known as paroisses (parishes) and those under British were known as cantons (townships). The 1831, 1842 and 1851 censuses can help us highlight those differences. They also testify to the importance of reconsidering the role of seigneurial tenure in compounding to the problems of New France. Although these censuses are well beyond the era of my study, they are the only ones offering wide rather than long comparisons of living standards.

Each of these censuses provide pieces of information that suggest that there were important differences along institutional lines. The most useful census is that of 1831. It can be found online at www.familysearch.org although it is available from Library and Archives Canada. A sub-district compilation is available in the 1832 edition to the Appendix of the Journal of the House of Assembly of Lower Canada. ${ }^{421}$ Using that census is tricky with regard to attempting computations of output given that there is no breakdown of land acreage for farming. I only know the extent of land farmed. However, the census contains three useful pieces of information. The first concerns wheat prices in each parish or township. The second concerns wages in each parish or township. The third concerns vital statistics in each sub district. Taken together, these pieces of evidence suggest wide discrepancies in living standards across institutional lines. The 1842 census contains the same pieces of information, although many rolls from that census were lost, making the coverage very dubious (in fact, some historians are not aware of its existence).

The first two pieces of information allow us to generate a measure of the marginal productivity of labor. Indeed, by dividing the daily wage rates by the price of a unit of wheat, I obtain a measure of grain wages. Grain wages are not uncommon in economic history as a comparative tool. They were used by Kenneth Pomeranz to argue that the gap between Asia and Europe was not as large in the late eighteenth century as numerous historians have made it out to be. ${ }^{422}$ Grain-wages have come under criticism. The criticism was advanced by Stephen Broadberry and Bishnupriya Gupta who argued that there was a gap between silver wages and grain wages (the former showing a larger gap between Northwest Europe and Asia than the latter during the eighteenth century) that can actually be used as a measure of development. ${ }^{423}$ This is based on the

\footnotetext{
${ }^{421}$ House of Assembly of Lower Canada. 1832. Appendix U to the Journal of the House of Assembly of Lower Canada. Québec: Neilson and Cowan, unpaginated.

${ }^{422}$ Kenneth Pomeranz. 2000. The Great Divergence: China, Europe, and the Making of the Modern World Economy. Princeton, NJ: Princeton University Press.

${ }^{423}$ Stephen Broadberry and Bishnupriya Gupta. 2006. "The Early Modern Great Divergence: Wages, Prices and Economic Development in Europe and Asia, 1500-1800”, Economic History Review, Vol.59, no.1, pp.2-31.
} 
recognized tendency for wages and prices to be higher in developed economies thanks to the productivity of the traded goods sector. Grain wages could be equal across space but silver wages would differ thanks to differences in productivity in tradables. The area with higher silver wages would be able to consume more non-food goods so that consumption is greater. In the case of Lower Canada, the grain wages would act as a conservative measure of living standard differences between seigneurial and freehold areas while the nominal wages would act as a more liberal measure.

The resulting computation, although further work is required, shows that there were significant differences in wages across the colony. The areas under seigneurial law had both lower nominal wages and lower grain-wages. As Tables 6.1 and 6.2 show, this is true for 1831 and 1842. Now, it ought to be mentioned that the prices shown below do not include urban areas. I have excluded wage and price observations for the districts of Montreal and Quebec and the parish of Trois-Rivières which excludes the three largest urban centres.

Table 5.1: Wages and grain wages in the 1831 census across institutional lines

$$
\text { Wages (shillings per day) Grain Wages }
$$

\begin{tabular}{ccc}
\hline Township & 2.18 & 0.35 \\
Seigneurial & 1.77 & 0.29 \\
Ratio & $\mathbf{8 1 . 2 4 \%}$ & $\mathbf{8 2 . 9 6 \%}$ \\
\hline
\end{tabular}

Note: For the 1831 census, wages could be found for 218 parishes and townships while prices were found in 212 .

Table 5.2: Wages and grain wages in the 1842 census across institutional lines

$$
\text { Wages (shillings per day) Grain Wages }
$$

$\begin{array}{ccc}\text { Township } & 2.78 & 0.414 \\ \text { Seigneurial } & 2.09 & 0.354 \\ \text { Ratio } & \mathbf{7 5 . 1 8 \%} & \mathbf{8 5 . 5 1 \%}\end{array}$

Note: For the 1842 census, the rolls can also be found online at www.familysearch.org in the forms of images that can easily be consulted. Overall, wages could be found in 48 parishes and townships while prices could be identified in 46.

One could fail to be convinced by this evidence given the size of Quebec (and thus variations in geographical settings). This is a non-issue. Within similar key areas, there are very wide differences in living standards. Within the colony, there were seven counties which had mixed institutional regimes: Beauce (south of Quebec), Kamouraska (east of Quebec), L'Assomption (northwest of Montreal), Missisquoi (southeast of Montreal), Saint-Maurice (northeast of TroisRivières), Terrebonne (northeast of Montreal) and Vaudreuil (west of Montreal). In all of these counties, the subdistricts that are townships have superior or equal living standards as can be seen in Table 5.3. 
Table 5.3. Grain wages (minots per day of work) in different institutionally-mixed counties

\begin{tabular}{cccc} 
COUNTY & Seigneuries & Townships & Ratio township/seigneurie \\
\hline Beauce & 0.25 & 0.30 & $120 \%$ \\
Kamouraska & 0.27 & 0.38 & $141 \%$ \\
L'Assomption & 0.23 & 0.29 & $126 \%$ \\
Missisquoi & 0.45 & 0.45 & $100 \%$ \\
Saint-Maurice & 0.25 & 0.27 & $108 \%$ \\
Terrebonne & 0.27 & 0.32 & $119 \%$ \\
Vaudreuil & 0.29 & 0.30 & $103 \%$ \\
\hline
\end{tabular}

Note: Other counties were institutionally mixed (that of Beauharnois), but as will be seen below, there were no wage rates for seigneurial estates.

There are also cases of variations within very similar regions across counties. The most interesting is that of Upper St-Lawrence Valley. This region has the most fertile grounds of the province. ${ }^{424}$ Within that region, agriculture faces auspicious conditions, but colonization of the area occurred later and numerous settlements were opened as townships during the 1780s and 1790s. ${ }^{425}$ In close proximity are the counties of Beauharnois Vaudreuil, La Prairie and Acadie. All these areas share important geographical similarities. ${ }^{426}$ The subdistricts of these counties all operated under seigneurial law with the exception of the small township of Newton, opened in 1805 , in the county of Vaudreuil and the county of Beauharnois where a sizable share of the population lived under freehold tenure in 1831. Sadly, no wage rates were recorded for the seigneurial estates within Beauharnois. However, the townships in Beauharnois exhibit sizably different wage levels from the other counties. As can be seen in Table 5.4, the townships in Beauharnois have grain wages close to 0.45 minots of wheat per day. The closest observation is in La Prairie at 0.33 minots of wheat per day. Within the region, prices for wheat are nearly equal, only the wages differ.

Table 5.4. Grain wages (minots of wheat per day) of counties with different institutions in the Upper St-Lawrence Valley

\begin{tabular}{cc} 
COUNTY & Grain Wage \\
\hline Beauharnois (townships) & 0.45 \\
La Prairie (seigneuries) & 0.33 \\
Vaudreuil (seigneuries only) & 0.29 \\
Acadie (seigneuries) & 0.27 \\
\hline
\end{tabular}

The same reality can be observed in two regions located more to the east: the area of La Beauce and the area of Shefford and Rouville. The Beauce area was settled during the early French rule except for the township of Frampton whose settlement occurred in the early nineteenth century. In close proximity are the townships of the county of Mégantic. Roughly 100 kilometers

\footnotetext{
${ }^{424}$ Mario Filion, Jean-Charles Fortin, Roland Viau and Pierre Lambert. 2000. Histoire du Haut Saint-Laurent. Québec : Presses de l'Université Laval et Institut Québécois de Recherche sur la Culture, pp. 31-33.

${ }^{425}$ Ibid, p.76.

${ }^{426}$ Agrométéo. 2015. Atlas Agroclimatique du Québec. Québec : CRAAQ (http://www.agrometeo.org)
} 
west of that area we find the other pair of counties-Rouville and Shefford. Both counties are settled under different institutional regimes-Rouville operating under seigneurial law and Shefford under freehold tenure. As with the case of the Upper St-Lawrence Valley, zooming in on these regions greatly minimizes regional variations in climate. Surprisingly, the township of Frampton exhibits a level of grain wages roughly equal to those found for the townships in the county of Mégantic. The parishes in the county of Beauce that operate under seigneurial law are well behind Frampton and the townships of Mégantic (see Table 5.5). The differences between StHyacinthe, Rouville and Shefford are more striking. The areas of Rouville and St-Hyacinthe had been settled for longer. The land was of high quality relative to what was found in Shefford. The land quality in Shefford is poor in the sense that rock sediments are close to the surface which makes the area relatively unsuitable for farming. Its soils are quite acidic, are void of limestone and phosphor and are considered to be of "mediocre fertility." 427 In addition, the region is far removed from the natural transportation network provided by the St-Lawrence seaway. The debit of the rivers riddling the region made water transport relatively prohibitive. ${ }^{428}$ In combination with the ruggedness of the area, roads were hard to build while the colonial administration had been inefficient at investing in such infrastructure. ${ }^{429}$ Given the potency of factors that should play against Shefford, it is surprising to find that - as can be seen in Table 5.6-townships in the Shefford county have higher rates of grain wages than those in Rouville and St-Hyacinthe.

Table 5.5: Grain wages (minots of wheat per day) of counties with different institutions in the counties of Mégantic and Beauce

\begin{tabular}{cc} 
COUNTY & Grain Wage \\
\hline Mégantic (all townships) & 0.31 \\
Beauce (township of Frampton) & 0.30 \\
Beauce (seigneuries only) & 0.25 \\
\hline
\end{tabular}

Table 5.6: Grain wages (minots of wheat per day) of counties with different institutions in the counties of Rouville, St-Hyacinthe and Shefford.

\begin{tabular}{cc} 
counties of Rouville, St-Hyacinthe and Shefford. \\
COUNTY & 0.42 \\
Shefford (townships) & 0.33 \\
Rouville (seigneuries) & 0.21 \\
\hline St-Hyacinthe (seigneuries)
\end{tabular}

An additional piece of evidence comes from using the census of 1851, available in the books of the Legislative Assembly of the colony. ${ }^{430}$ That census provided detailed information about

\footnotetext{
427 Jean-Pierre Kesteman, Peter Southam and Diane Saint-Pierre. 1998. Histoire des Cantons de l'Est. Québec : Presses de l'Université Laval, pp.49-51.

${ }^{428}$ Ibid, p. 101 .

${ }^{429}$ Ibid, pp.101-106.

${ }^{430}$ Government of the Province of Canada (1853). Census of the Canadas, 1851-1852, Volume I. Quebec: John Lowell Printer.
} 
deaths by age group. From this, I can construct infant mortality rates and quotients. ${ }^{431}$ Intuitively, if seigneurial tenure did indeed make the censitaires poorer, the effects of poverty could be seen on infant mortality rates. This is because the effects of poverty are most robustly seen in childhood. Poverty increases vulnerability to shocks which meant wide swings in nutritional intake. Nutritional deficiencies for pregnant mothers meant that net energy intake would be smaller than needed to ensure proper development of the fetus, reducing chances of early-life survival. ${ }^{432}$ Otherwise, poor or unstable nutrition after birth could increase early-life mortality risks. ${ }^{43}$ If seigneurial law did really transfer such a substantial share of income (10 to $14 \%$ of gross income as seen above) from peasants to landlords, it would have increased poverty and this poverty could be observed in differences in infant mortality rate. Table 5.7 shows that, for 1851, the infant mortality rates were higher in seigneurial estates than in non-seigneurial estates. These differences seem to fall well in line with the wage differences across regions observed earlier.

Table 5.7: Infant mortality quotients (deaths per 1,000) across institutional lines, 1851

\begin{tabular}{ccc}
\hline Infant mortality rate & 95.0 per 1,000 & 44.7 per 1,000 \\
Infant mortality quotient (ages 1 to 5) & 26.0 per 1,000 & 15.6 per 1,000 \\
\hline
\end{tabular}

The final piece of supporting evidence in favor of reconsidering the role of seigneurial tenure comes from the natural experiment provided by the Constitutional Act of 1791. The French rule era prohibits any effort at testing these effects since the entire colony operated under seigneurial tenure. In this situation, it is difficult to establish a counterfactual scenario for what could have been had seigneurial tenure not been present. However, the post-conquest era offers a suitable test. Upon the conquest of the colony by the British, the seigneurial system was maintained, but in the Constitutional Act of 1791 it was frozen to the areas where it had already been established-it could not expand. All new settled lands past 1791 would have to be settled under freehold. However, the British allowed a system of voluntary commutation of seigneurial estates. Few would use this right. ${ }^{434}$ Hence, the colony geographically "locked" the institutional systems of tenure. As

\footnotetext{
${ }^{431}$ Rates are compared over 1,000 births, quotients are relative to each age group (deaths between ages 1 and 5 over the population alive between ages 1 and 5).

432 David Meredith and Deborah Oxley. 2014. "Nutrition and health, 1700-1870" in eds. Roderick Floud, Jane Humphries and Paul Johnson, The Cambridge Economic History of Modern Britain, Vol.1, 1700-1870. Cambridge: Cambridge University Press, p. 142-144.

${ }^{433}$ Roderick Floud, Robert Fogel, Bernard Harris and Sok Chul Hong. 2011. The Changing Body: Health, Nutrition and Human Development in the Western World since 1700. Cambridge, MA: National Bureau of Economic Research. ${ }^{434}$ House of Assembly of Lower Canada. 1835. Appendix KK to the Journal of the House of Assembly of Lower Canada. Québec: P.G. Desbarats. Note: from 1826 to 1835, only 21 requests for voluntary commutations were asked - mainly for urban areas - representing $10 \%$ of all seigneuries. Moreover, none of these twenty-one demands was made for full commutation; all the demands were partial and applied only to uncleared lands which they could sell
} 
a result, large areas of Quebec were settled under British land tenure laws. Although Englishspeaking settlers preferred the system, many French settlers opted to live in township estates as well and decided to mingle with English speakers by living under their land laws. In the census of 1851, above $40 \%$ of the population of the areas under English land laws were of French-Canadian origin (with $22 \%$ of the total population living in those areas and compared with $88 \%$ of the population of areas under French law being of French origin). ${ }^{435}$ The 1844 census, whose individuals rolls are lost, report that the five counties of the Estrie region (Mégantic, Missisquoi, Shefford, Sherbrooke and Stanstead) had respectively 37.98\%, 13.70\%, 28.38\%, 9.54\% and 5.29\% of their populations which was French-Canadian origin. ${ }^{436}$ These counties were organized as townships by English settlers initially between the late 1790s and early 1800s. Between the censuses of 1844 and 1851, the population of French-Canadian origins had roughly doubled as a share of the total population of the eastern townships. The migration of French-Canadians to these areas is an indirect confirmation that, in spite of natural disadvantages in the region, there were considerable gains to be had from migration. Given the strength of the migration to these areas, it is fair to say that there was some preference for townships over seigneuries. Some might say that migration to areas where wages are higher is to be expected, but the fact that wages are higher in spite of a greater set of adverse environmental conditions (remoteness and poor land quality) and adverse social conditions (French settlers would meet some hostility from longer-established English and American settlers) ${ }^{437}$ suggests that there is an important net advantage of not being under seigneurial law.

Table 5.8: Share of the population of the districts of eastern townships which was French-

\section{Canadian}

\begin{tabular}{lcc} 
Counties & 1844 & 1851 \\
\hline Mégantic & $37.98 \%$ & $60.93 \%$ \\
Missisquoi & $13.70 \%$ & $21.05 \%$ \\
Shefford & $28.38 \%$ & $44.23 \%$ \\
Sherbrooke & $9.54 \%$ & $14.65 \%$ \\
Stanstead & $5.29 \%$ & $9.30 \%$ \\
Total & $\mathbf{1 6 . 6 1 \%}$ & $\mathbf{3 0 . 4 7 \%}$
\end{tabular}

Note: These five districts are not the sum of townships, each of these census districts are composed of a greater number of sub-districts.

\footnotetext{
${ }^{435}$ Government of the Province of Canada (1853). Census of the Canadas, 1851-1852, Volume I. Quebec: John Lowell Printer.

${ }^{436}$ Detail by counties were provided by Statistics Canada which until 2012 kept county-level versions of the available data.

437 Jack Little. 1989. Ethno-Cultural Transition and Regional Identity in the Eastern Townships of Quebec. Ottawa: Canadian Historical Society.
} 
Future researchers should concentrate on this natural experiment between seigneurial tenure and freehold tenure. The differences in outcomes that I have underlined above suggest the validity of such an undertaking.

\subsection{Conclusion}

The goal of this section of my dissertation was to provide a discussion of what would explain the economic performance of New France. Such explanations would require a dissertation by themselves. It is beyond the scope, and the ability, of the current dissertation to provide such answers. However, it is possible to present manners in which to orient future research. In essence, this section speculates as to the possible causes.

Linkages between economic growth and population size would be the main backdrop of any discussion on why Quebec diverged from the rest of North America. This is because one has to exclude Schumpeterian growth in the form of technological innovation prior to the $1760 \mathrm{~s}$. Technological innovations were much more predominant from the mid-nineteenth century on. When growth did occur, it was mainly through Smithian channels whereby allocative efficiency would rise as a result of a larger population permitting greater economies of scale and scope for specialization.

However, this is not a sufficient explanation. Institutions must have played some roleespecially since there were such important differences between New France and Colonial America with regard to land tenure laws. The peculiar institution of seigneurial tenure is a likely candidate. Determining the true extent of the effects of seigneurial tenure is beyond the scope of this dissertation. However, the aim of this section was to say that it is incorrect to disregard its importance. It was likely important, but how much so is hard to tell. Further research into the impact of seigneurial tenure would be needed. However, it is clear that this peculiar institution compounded the structural problem of a small population size. 


\section{PART 6: CONCLUSION}


This thesis started by saying that "Quebec matters." It matters because it is a peculiar society within North America. Its culture, its language, its religion and its legal institutions are largely different from the rest of the continent. Yet, it shares numerous geographical similarities with its American neighbors, especially New England. Nonetheless, for most of the nineteenth century and twentieth century, it has been an economic laggard with significant gaps in living standards relative to its neighbors. It is this divergence that should matter to economic historians.

It allows the addition of another observation to the study of divergence within the Americas. Its economic difference within Canada is marked and has been the subject of great debates since it was conquered by the British in 1760, and it has diverged markedly from the United States. The goal of this thesis was to create a quantitative portrait in order to create an estimate of the differences in living standards in the colonial era.

The results of this thesis can allow us to tackle numerous questions. First of all, it is the first step in solving the important debate over the effects of the Conquest of Quebec in 1760. Secondly, it is the first step in documenting economic growth in Canada and Quebec prior to Confederationsomething of importance to Canadian economists and historians. Thirdly, it allows us to see whether or not the New World did enjoy an advantage relative to the old world in terms of living standards. Most importantly, it allows us to delve into the issue of the colonial origins of divergence within the Americas.

To get to the results, considerable efforts were deployed to collect broad datasets in order to measure living standards in the colony. The novelty of this thesis was mostly the creation of a dataset drawn from the archives of religious congregations in Quebec City. This dataset of wages, prices and piece rates in combination with census data, vital statistics and probate records provides the broadest empirical portrait of the colony of Quebec ever constructed.

The results of this thesis have been quite broad as we have discovered the following facts:

1. The creation of a price index which future researchers will be able to use to deflate nominal values.

2. The absence of economic growth between 1688 and 1760 - an observation that holds whether I use real wages or a measure of gross domestic product (GDP).

3. Real wages standardized as welfare ratios at the subsistence level show that New France was not significantly richer than France, that it was poorer than England and the American colonies.

4. Real wages standardized as welfare ratios at the respectable level show that New France was poorer than France and much poorer relative to England and the American colonies. In combination with point 3 , this suggests that it was easy to acquire land-intensive goods 
in New France but much harder to acquire capital-intensive goods as well as imported goods. When greater proportions of manufactured and non-farm goods are included in the basket, the inhabitants of Quebec see their advantage dwindle to parity with the French or, in the worst case scenario, turn to a disadvantage. Relative to the Americans, the situation worsens.

5. Welfare ratios suggest that New France's relative poverty places it in line with some Spanish colonies relative to the American colonies. Hence, the presence of a sizable divergence within North America suggests that the colonial origins of divergence should focus on what made the American colonies unique.

6. Shifting to a measure of income per person instead of real wages suggests that New France's position relative to the American colonies does not change dramatically (if anything, it deteriorates slightly). Relative to Europe, it suggests that New France's harsh climate limited the length of the work year. Hence, real wages overstate New France's relative advantage over France.

7. Income per capita did rise by roughly $20 \%$ between 1688 and 1740 , but this could have been the result of longer work years. It would have also have been made possible by the long peaceful period of 1713 to 1740 . Episodes of peace were marked by steady growth which episodic wars kept rolling back to the 1688 levels.

8. There were signs of deterioration in the biological standard of living.

9. The poor economic performance of the colony can be largely explained by the small size of the population. However, the seigneurial system of land tenure with its numerous monopoly rights and taxing rights for landlords probably amplified the problem. Supportive evidence shows that, once the British had allowed settlements under different institutional settings to cohabit alongside French land tenure laws, large differences in living standards appeared along institutional lines. This point suggests that future research should concentrate on reinstating seigneurial tenure into the debate.

These results confirm the importance of the colonial origins of divergence. Indeed, Quebec was poorer than all other areas in North America from the start. In consequence, Quebec's relative poverty in Canada and North America is in no way something exceptional - it was there from the very beginning. The results limit the ability to claim that Quebec ended its economic development when it was conquered by the British as there had been no improvements. It places into perspective the "exceptionalism" of the American experience at that time. The results of Lindert and Williamson on early American economic growth placed the colonies as the richest (even when slaves were included) in the world. Some could have been tempted to assert that the New World, void of Malthusian pressures given the abundance of land relative to its small population, was bound to show higher standards of living than densely populated Europe. Yet, the divergence of Quebec — which bears so many environmental similarities to the American colonies studied here- 
points to the contrary. In doing so, it confirms that the colonial origins of divergence are crucially important and that there was something exceptional going on in the future United States.

Obviously, this thesis constitutes only the first (albeit large) step of an effort to quantify Canada's early economic history. The question of the Conquest cannot be answered until more is known about growth in the era from 1760 to 1867. In the process of collecting the data for this thesis, I also collected prices and wages useful for the elaboration of this next venture which will be essential in studying properly the economic importance of Canada's conquest by the British in 1760. Nonetheless, this was an imminently important first step along what should be a long road to a proper understanding of the evolution of the economies of Quebec and Canada before the twentieth century. 


\section{APPENDIX 1: DetaILS OF PRICES WITH ADDITIONAL INFORMATION}




\section{Price and wages sources}

The Ursulines and the Séminaire de Québec were religious estates who owned seigneurial estates from the very early days of colonization. Their estates were vast. Overall, religious congregations owned $25 \%$ of all conceded lands in the colony and $34 \%$ of the population lived on their estates. ${ }^{438}$ The Ursulines was one of the smaller congregations. Its estates were concentrated around the Quebec City area, but they were found on both shores (the seigneurie of Sainte-Croix was located on the southern shore of Quebec City in what is now the municipality of Sainte-Croix de Lotbinière). ${ }^{439}$ On the other hand, the Séminaire de Québec had much grander holdings. Most of them were concentrated around Quebec City, but they held the very important seigneurie of Île Jésus which is an entire island north of Montreal. The Séminaire also diversified its economic activities - it owned saw mills, transport ships, flour mills and farms. ${ }^{440}$ Their estates are illustrated on maps A1.1 and A1.2 below. The advantages of these estates and the structure are that I am not capturing urban prices, but rather prices in the hinterland where the vast majority of the population lived. In addition, as mentioned in the chapter on real wages, the wages are mostly agricultural in nature. The data has numerous advantages with regard to wages; the ability to distinguish payment in cash from payment in kind; the ability to distinguish skilled and unskilled workers and; most observations are related to agriculture which employed the vast majority of the population.

\footnotetext{
${ }^{438}$ Cornelius Jaenen. 1976. The Role of the Church in New France. Toronto: McGraw Hill, p.71

${ }^{439}$ Jessica Barthe. 2015. L'Administration seigneuriale derrière la clôture : les Ursulines de Québec et la seigneurie de Sainte-Croix. MA thesis, department of history, Université de Sherbrooke.

${ }^{440}$ Baillargeon, Noël. 1977. Le Séminaire de Québec de 1685 à 1760. Québec: Presses de l’Université Laval.
} 
Map A.1.1. Estates of the Séminaire de Québec

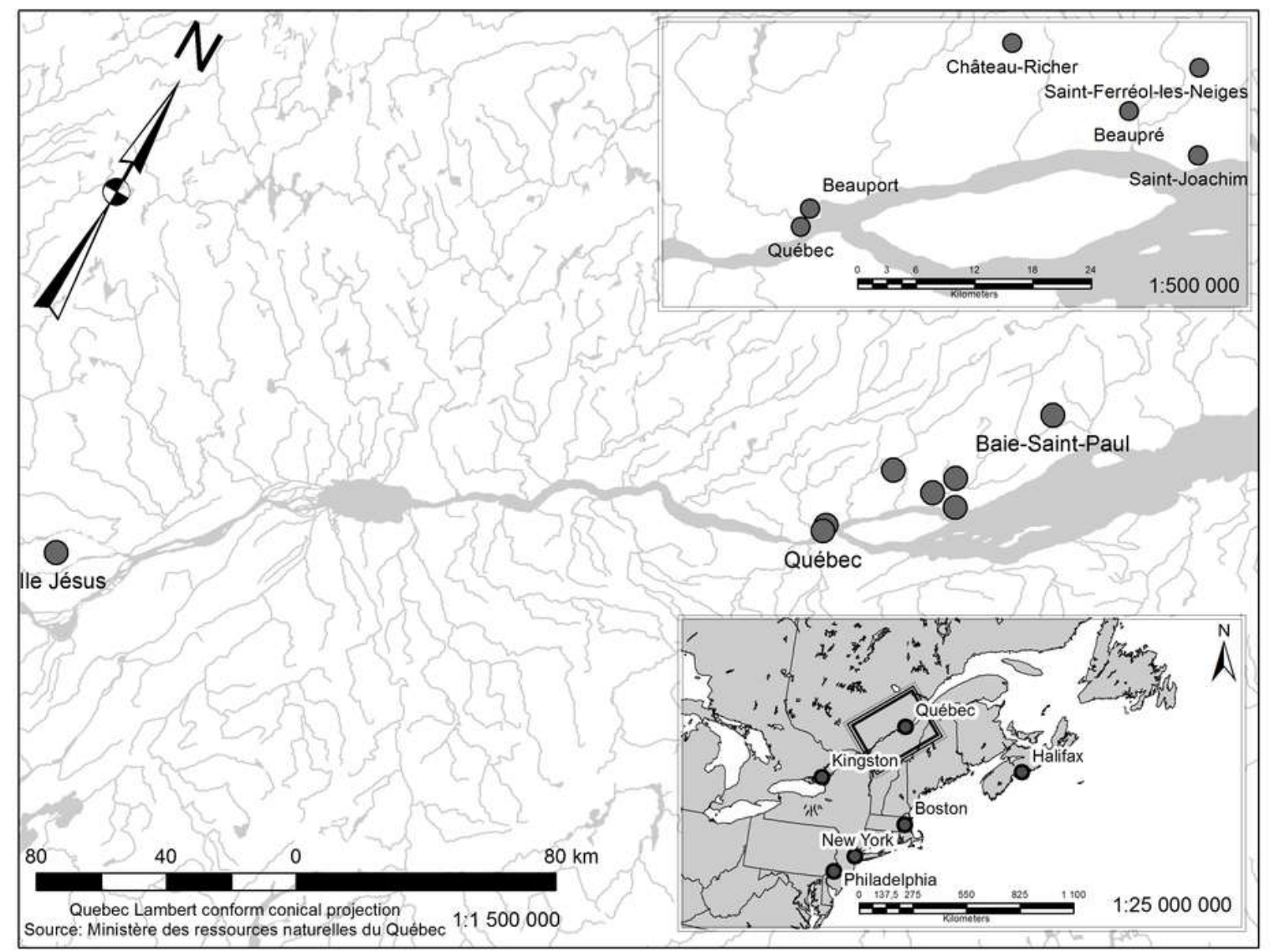


Map A.1.2. Estates of the Ursulines de Québec

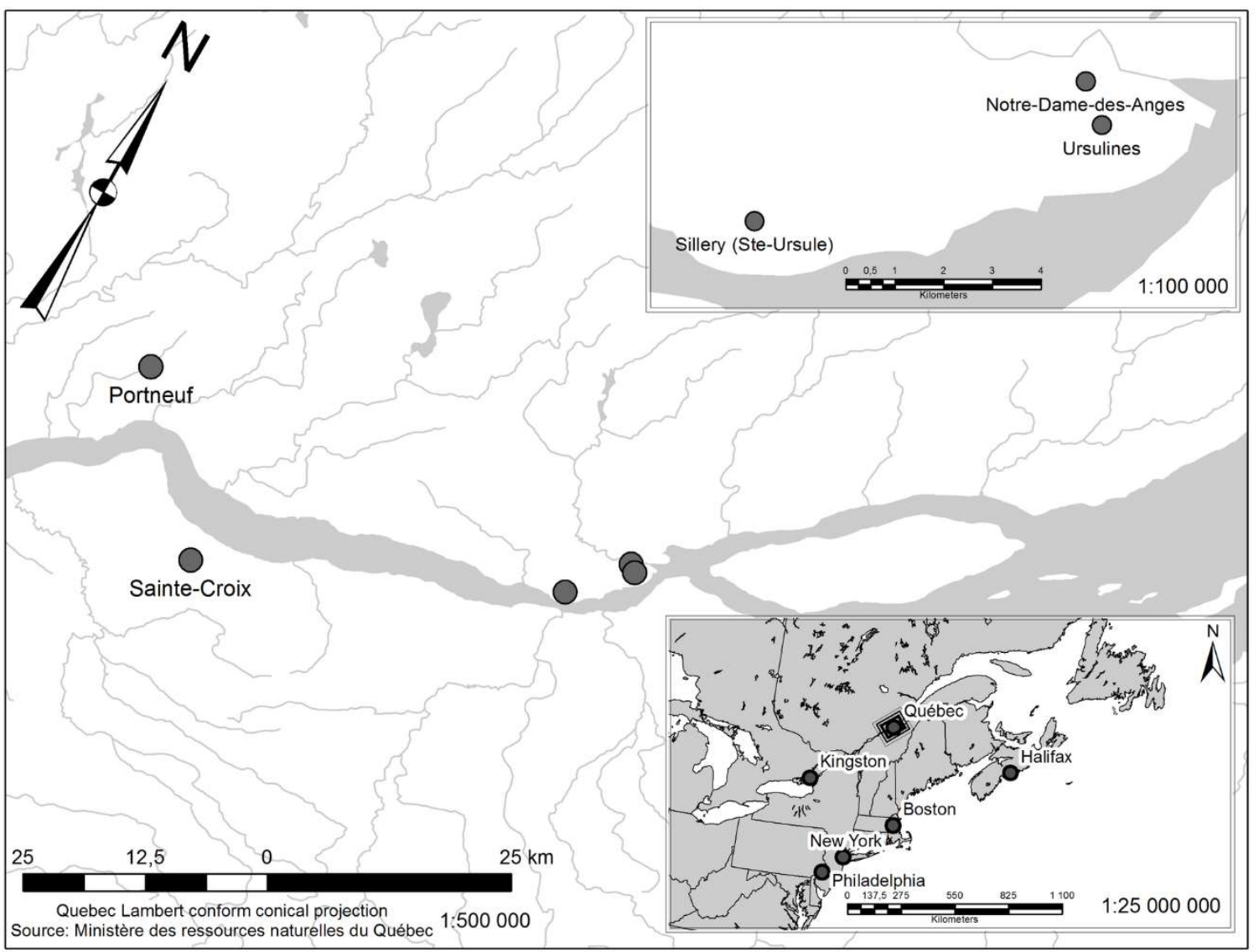

\section{Metrological System and Conversion}

It should be noted that the units of measurement used to measure goods changed in some years. For example, codfish could be sold by the pound, the unit, by the poignée, or by the quintal. Thankfully, Rousseau provided equivalences in his work on the Augustine congregation that ran the hospital in Quebec City. These are illustrated in Table 2, below. One should be very careful not to confuse the French livre and the English pound. Although the two are linguistically identical (livre in French means pound in English), they represent different weights in grams. The French livre (translation for pound) carries 489.5 grams against 453.6 grams for the English pound, a $7.91 \%$ difference. In the course of my research, I have seen historians derive conclusions without making this important correction. 
Table A1.1. Measures in the French regime

$\begin{array}{ccc}\text { TYPE OF ITEM } & \text { UNIT USED FOR THIS PAPER } & \text { OTHER UNITS AND THEIR } \\ \text { CONVERSION RATES }\end{array}$

Source: François Rousseau. 1983. L'œuvre de Chère en Nouvelle-France : Le régime des malades à l'hôtel-Dieu de Québec. Québec Presses de l'Université Laval, p.394-396; Christoph F. Grieb and James Oehlschläger. 1857. A Dictionary of the English and German Languages, with a Synopsis (...), Vol 2. Philadelphia, PA: John Meif, p. 1132.

\section{Organization of the data}

The data is organized differently by both religious congregations. The Ursulines organized their account books chronologically whereby all transactions in a month were detailed as a debit or credit but without regard to the contracting parties. The Séminaire had also such books, named the Brouillard, but these were written poorly and were (probably) drafts of what would end up in the Grand Livre which was organized by account with dates specified. I should mention that during the year when I collected prices, I was not authorized to take pictures of the documents. However, at the end of that year, the authorities at both the Séminaire and the Ursulines relented. The Séminaire allowed me to use a scanner to digitize the microfilms of all account books from 1674 to 1880 while the Ursulines authorized me to photograph the physical documents. Both institutions required me to sign confidentiality agreements with the pictures and digitisations. However, they mentioned that I could share the data with co-authors and research assistants. Other researchers will have to contact them to ask permission to share the images. 


\section{Other potential sources}

There are other congregations that could have offered price and wage information. One of them is the Augustines in Quebec City. The Augustines were the topic of another book, that of the frequently mentioned François Rousseau. ${ }^{441}$ However, the data collected by Rousseau has been presented in a manner which prevents replication. Moreover, their main activity was the running of a hospital in Quebec City and they had much smaller estates than the Séminaire and the Ursulines. Other congregations offer limited information. One of the other important congregations, the Récollets, has no archives available while the Ursulines de Trois-Rivières (which operated its account books independent of the Ursulines de Québec) has no data prior to 1806. The remaining congregations that would offer more data would be the Jesuits and the Sulpicians. The Jesuits have very well organized archives, however they were expelled at the time of the British conquest and their activities stop until 1842. Since my aim was to collect prices and wages from continuous sources up to 1760 which could then be extended past that point up to 1867 , the Jesuits are not suited to my aims. The Sulpicians were a better fit. They owned the Island of Montreal up to 1840 . Consequently, it would provide a great source to map out regional price differences. However, the equal-weight price indexes for Montreal and Quebec City for 1760 to 1860 show that they behaved in nearly identical manners. ${ }^{442}$ As a result, the addition of Montreal would not change the picture dramatically. Since I spent nearly a year in the archives of the Ursulines and the Séminaire to collect prices and wages, expending the same effort for the Sulpicians in the frame of a doctoral dissertation was seen as overzealous. However, I should point out that it is my intention in the future to expend resources to collect prices and wages from the Sulpicians in order to complete the picture.

\section{Details about goods, their prices and interpolation}

The method used to compensate for missing data points was as follows: I took the price of these goods relative to that of wheat per five-year period (except for the periods 1688 to 1694 and 1755 to 1760 ) and took the average over the period to complete the gaps. This is a small variant of the approach used by Desloges in his attempt to derive a price index based on probate records (which contained more gaps than mine and much fewer goods). ${ }^{443}$ Three goods did not lend themselves to this interpolation method: candles, sugar and cloth. Below is the list of the interpolation needed. It should be pointed out that not all of the prices used in Chapter 3 (the price

\footnotetext{
441 Rousseau, François. 1983. L'ouvre de Chère en Nouvelle-France : Le régime des malades à l'hôtel-Dieu de Québec. Québec Presses de l'Université Laval.

${ }^{442}$ Gilles Paquet and Jean-Pierre Wallot. 1998. "Some Price Indexes for Quebec and Montréal (1760-1913)", Histoire Sociale / Social History, vol.31, no.62, pp.281-320.

${ }^{443}$ Yvon Desloges. 1991. A Tenant's Town: Quebec in the 18th century. Ottawa: Parks Canada.
} 
index) are used in Chapter 4 (welfare ratios). For the price index, interpolation was not seen as problematic, but they could have been more problematic for the welfare ratios. However, the vast majority of the goods used for the welfare ratios did not require interpolation. While prices were available continuously

Wheat: The predominant crop of New France, its inclusion was crucial given that the literature gives it roughly three fourths of the land sown in the colony.

Coverage: All years were accounted for.

Used for welfare ratios: Yes

Firewood: An obviously important item in the cold weather of Canada, special care had to be attributed to its manipulation. First of all, it was reported as a corde of the French metrological system which is not the same as a cord in the British metrological system (see Chapter 4). Secondly, the Séminaire and the Ursulines often had to pay for the wood plus the cost of transport. Reported as charroy or charrier, it is necessary to retract this amount from the total price as this would reflect the urban price premium. Peasants who owned their own farms and simply chopped firewood in order to heat their households while clearing land in the hinterland would not pay that premium.

Coverage: All years were accounted for

Used in welfare ratios: Yes

Wood planks: Since the Séminaire operated a sawing mill; it often reported prices for planches de bois (wood planks) which were closer to finished products. These were sold by the hundred (le cent) and were distinctive from madriers (wood beam) which were slightly more expensive (but also sold by the hundred).

Coverage: The missing years are 1744, 1745, 1746, 1748, 1750, 1757 and 1759.

Used in welfare ratios: No

Shoes (souliers de France): Either called souliers normands or souliers de France, these shoes were mostly used for interior or periods of mild weather. Distinctions exist within this category of shoes as there were shoes for women and for children, both of which were generally less expensive than shoes for adult men.

Coverage: The missing years are 1741, 1743, 1755 and 1756.

Used in welfare ratios: No

Souliers sauvages: The souliers sauvages were also known as the moccasins à l'indienne, referring to the fact that the usefulness of these shoes was discovered after cultural contact with the natives of Canada who showed the colonists how useful these would be in winter. 
Coverage: The missing years are 1710, 1711, 1718, 1728, 1743, 1746, 1747, 1756, 1757, 1759 and 1760 .

Used in welfare ratios: No

Wine: Price quotations rarely made a distinction between red and white wine. A "pot de vin" was often all that was mentioned. When this was specified, the price was often the same for both products. As a result, I felt that they were interchangeable without any loss of informational quality. Forays into the data past 1760 shows that this is not the case after that point since the British begin importing "vin de port" (porto) and "vin de ténériffe" (Spanish wines).

Coverage: The missing year is 1758

Used in welfare ratios: Yes

Spirits (eau de vie): I did not consider guildive only "eau de vie." "Guildive" was a rum which was imported from the French West Indies. The problem was that when the researcher found references to "eau de vie" and "guildive" in the same month, their prices were very different with guildive being more expensive. Hence, I felt that he could not use guildive prices, which were not reported very often, anyhow.

Coverage: The missing years are 1744, 1754, 1758 and 1759.

Used in welfare ratios: No

Oats: This crop was significant in the colony and was often used as feed for livestock. In importance, it was either the second or third largest crops (in competition with peas) after wheat.

Coverage: All years were accounted for.

Used in welfare ratios: Yes

Peas: Second only to wheat, peas were used to feed both farm households and livestock. Coverage: The missing years are 1705, 1728, 1741, 1746, 1752.

Used in welfare ratios: Yes

Bran: A residue of milling, bran was generally used as a cheap grain to feed animals.

Coverage: The missing years are 1728, 1729, 1733, 1741, 1742, 1743, 1749, 1750, 1751, 1752 and 1759.

Used in welfare ratios: No

Flour: Although subject to price controls (the administration often fixed the price in times of scarcity), flour was a key element in the diet of Canadians. Direct bread prices would have been preferable; however, as indicated above, explicit mention of the weight of bread 
is very rare in the documentation. For example, researchers do know that a piece of bread was sold for 8 sols, but we do not know exactly how many grams of bread this represented. In some years, like 1703, I did find mention of the cost per unit of weight, but this occurred only for two different years. As a result, the price of flour constituted a reasonable proxy in the price index. However, it was not used in the welfare ratios for this reason. This is why, as I explained above, I opted to recalculate the baskets for France and other regions on the basis of wheat rather than bread. I am aware that this is not perfect, but it is a superior alternative to attempting to create a bread price measure from a price controlled series on flour.

Coverage: The missing years were 1754, 1755 and 1759.

Used in welfare ratios: No

Burning oil: Generally imported, but not always (it could be substituted by oils from sea products produced in the colony in especially dire times), burning oil was a major consumption item in New France.

Coverage: The missing years are 1688, 1689, 1745, 1755, 1759 and 1760.

Used in welfare ratios: Yes

Nails: This item does not figure prominently in many price indexes. However, since there was little mining being done in the colony and few metals were extracted, all metal-based items had to be imported, nails being one of those commodities. Moreover, this item also provided a continuous representation of the price of an item of metallic nature. With gaps in the documentation of iron and steel prices at numerous points, nails acted as a proxy for metals. Attention was given to using a consistently similar type of nail, the clou de plancher which was the most frequently reported unlike the clou de bardeau and clou à couvrir. Coverage: The missing years were 1738, 1744, 1745, 1750, 1754, 1756, 1757 and 1760.

Used in welfare ratios: No

Olive oil: An important item in the preparation and conservation of foodstuffs in the colony, it could also be substituted for fish oil in cooking. It was reliably reported.

Coverage: The missing years are 1743, 1744, 1745, 1750, 1755 and 1760.

Used for welfare ratios: No

Codfish: This was an important export item for the colony that colonists also consumed in reasonable quantities. Generally sold by the poignée, it would then be reported as morue verte or fraîche (fresh). Mentions of dried (sèche) codfish were associated with the unit of quintal. For this dissertation, I have relied on prices for fresh codfish. However, the mention of dried codfish appears sufficiently enough for future researchers to calculate the differences between fresh and dried codfish. This could lead to interesting studies in market integration since codfish was a frequently and heavily traded international commodity 
during the seventeenth and eighteenth centuries. I intend to undertake a venture into this topic in the near future.

Coverage: The missing years were 1688, 1690, 1745 and 1746.

Used for welfare ratios: No

Butter: Dairy products have been generally an important item in the agriculture of Quebec. Ill-suited for crop growing, Quebec is very well suited for herding animals. As a result, butter was an important good.

Coverage: The missing year is 1760

Used for welfare ratios: Yes

Hay: The price of feed for animals was reported by the hundred (le cent) bottes.

Coverage: The missing years are 1715, 1730, 1733, 1735, 1743, 1746 and 1760.

Used for welfare ratios: No

Lard: Lard was of great use in the diet of the colonist. Generally, low temperatures (as in the case of Quebec) require diets with greater amounts of calories. Lard was a cheap source of calories. In fact, it is still a common folkloric food item in Quebec today.

Coverage: All years were accounted for.

Used for welfare ratios: Yes

Socks: Socks were generally well reported; however I was careful not to consider bas de femmes, which were women's socks, and whose price was always slightly lower (by roughly $15 \%$ to $20 \%$ ), as being the same as for men's socks.

Coverage: The missing years were 1727, 1728, 1741, 1743, 1749, 1755, 1756, 1757, 1759 and 1760

Used for welfare ratios: No

Eggs: Egg prices were very well recorded in the archives of the Séminaire up to 1725 and then they were less frequently mentioned afterward. When they were, it was to say "this amount was spent on eggs" with no specification for quantities. However, the Ursulines reported dozens of transactions involving eggs every year from 1716 (the start date of their account books) to 1760 . From 1716 to 1725 , both sources showed egg prices behaving identically and being at similar levels.

Coverage: The missing years are 1696, 1699 and 1700.

Used for welfare ratios: Yes

Eels: This item's inclusion might seem surprising, but eels were a well-appreciated item in the diet of French Canadians living near the St-Lawrence River and its tributaries. 
Colonists found that it was a cheap source of calories. Some contemporary figures spoke of the population's fondness for eels with disdain. It was sold by the barrique generally but sometime by the cent (hundred) or by the unit.

Coverage: The missing years are 1730, 1740, 1741, 1758 and 1759.

Used in welfare ratios: No

Beef: Beef was sold by the livre and it was frequently consumed. This is a considerable advantage as I do not have to rely on the price of animals. This is a retail price. Some prices for veal, pork and sheep were found, but they were not as frequently consumed as beef. Coverage: The missing year is 1723

Used in welfare ratios: Yes

Soap: Soap was also sold by the livre, but it would have been an item used infrequently by the average household and in small quantities. It was one of the item for which the most observations were missing. Coverage: The missing years are 1697, 1703, 1704, 1706, 1708, 1715, 1718, 1724, 1726, 1740, 1741, 1744, 1745, 1749, 1750, 1752, 1754, 1755 and 1756.

Used in welfare ratios: Yes

Coal: When present, coal was sold by the pipe. I did not include it either in the price index nor the welfare ratios. Future research could use this price series, but to what use I am currently uncertain.

Coverage: The missing years are 1704, 1710, 1729, 1743, 1744, 1747, 1752, 1755, 1756, 1757, 1759 and 1760 .

Used in welfare ratios: No

Cloth (toile): Clothing items were measured by the aune and was imported in numerous kinds: carizé, indienne, mazamet, cotton, soie, mesly, de Russie, du païs, toile, d'herbes, voile, chanvre, azur, and molton. Wool, not faithfully reported in many years, was measured in livres. Numerous clothing items were luxuries whose prices differed massively from other cloth items. Hence, attention was given only to the cheapest kinds of cloth: 1) toile (unspecified type of cloth, which was always much cheaper than others reported in the same transactions and were generally rags); 2) d'herbes; 3) voile (a proxy for rough clothing items); 4) chanvre (hemp) and; 5) du païs or indienne which was domestically produced, generally of poor quality. These types of cloth would be the ones

generally consumed by the population as a whole. The others are of great quality and would have been used by aristrocrats, merchants and rich artisans.

Coverage: The missing years were 1729, 1739, 1740, 1741, 1743, 1746, 1749, 1755, 1756 and 1757. 
Used in welfare ratios: Yes

\section{Special cases of Interpolations: Candles and sugar}

Religious candles, tallow and candles: Candles were a hard item to include. The Séminaire faithfully reported candle prices in all years up to 1723 , but after that, mentions of them got scarcer. Before 1723, only two years are missing observations for regular candles. After 1723, there are wide gaps. The Ursulines also report these sporadically. This said, both congregations - being a religious institution-faithfully reported prices for cierges in nearly all years up to 1746. A cierge was a religious candle made from wax rather than tallow, and was harder to make. Tallow prices were also abundantly available past 1715 (thanks mostly to the Ursulines) with no missing observations past 1734. As can be seen in Figure A1.1, the index number for the three different goods follow very similar movements. As a result, I interpolated the price of tallow after 1720 .

Used in welfare ratios: Yes

Figure A1.1: Index of the prices of different illuminates (tallow, religious candles and common candles) where $1688=1$

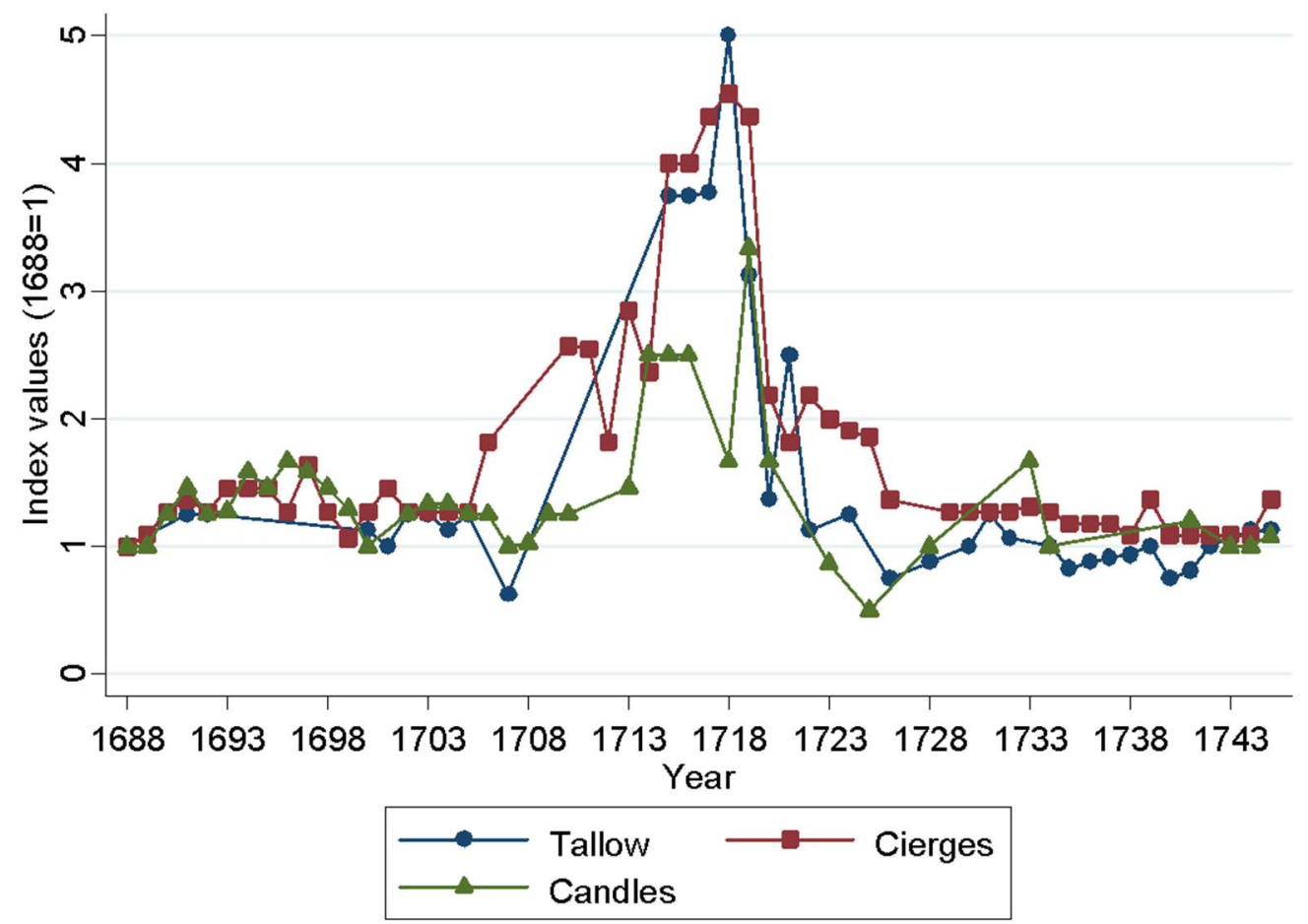


Sugar: Sugar was a very complicated item to include in the price index. First of all, there were numerous different types of sugar. There was sucre (sugar). This was constrasted with castonade which is "raw sugar". The problem is that the castonade could be presented as castonade, castonade blanche (white raw sugar), castonade rousse (red raw sugar), castonade brune (brown raw sugar). The fact that the mention of blanche is present for both sucre and castonade suggests that the religious congregations would use them interchangeably even if they were different. This was an important problem. As a result, I only considered raw sugar when it mentioned castonade, castonade brune and castonade rousse. Although I collected prices castonade blanche and sucre, I did not include them in the price index. For the raw sugar, there was an additional problem where there were two important gaps between 1690 and 1699, between 1703 and 1708. As a result, I had to rely on the prices collected by Yvon Desloges for raw sugar for these missing points. ${ }^{444}$ Then, I used the same interpolation method as for all the other goods.

Coverage (in the Ursulines and Séminaire data): The missing years are 1688, 1690 to $1699,1701,1703$ to $1708,1711,1717,1727,1728,1730,1731,1733,1734,1738$ to 1741 , 1744, 1745, 1747, 1750 to 1753,1759 and 1760.

Coverage (in the Desloges data): The years I used were 1691, 1695, 1697 and 1698.

Used in welfare ratios: No

${ }^{444}$ Yvon Desloges. 1991. A Tenant's Town: Quebec in the $18^{\text {th }}$ century. Ottawa: Parks Canada, pp.223-228. 


\section{Other prices, not used in price index}

Tobacco: There were different sorts of tobacco: noir (black), vert (green), du pays (from the colony), and des Indes (from the French West Indies). In terms of the earlier years (up to 1700), it was virtually impossible to distinguish between tobacco prices, so there was a lot of uncertainty for that period and numerous different prices mentioned. However, after 1700 , prices become clearer at lower levels. They were either vert or $d u$ pays, a difference which mattered very little since they were often priced at the same level. These issues were minor, but there are many missing points after 1740 , too many to reliably interpolate.

Figure A3.2: Price of tobacco (in sols per livre of 489.5 grams)

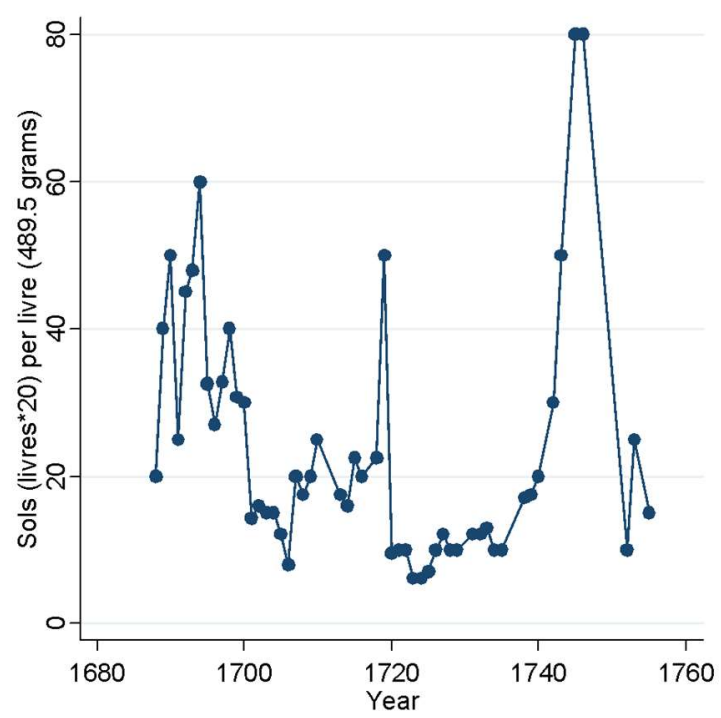


Pepper: A luxury item beyond the reach of the poorest individual, it was nonetheless a daily item in the diets of the richest individuals. It could not be included in this work because of an important gap in reporting between 1728 and 1744.

Figure A3.3: Price of pepper (in sols per livre of 489.5 grams)

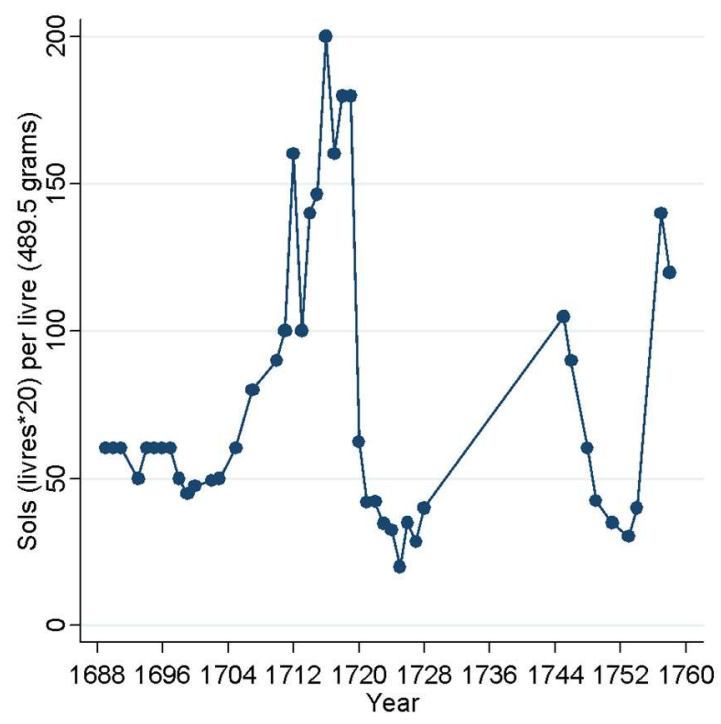


Apples: Apples would have been a very useful item to integrate inside the price index especially since, today, Quebec is well known for its apple orchards. As discussed in earlier sections, families did earn an income from picking fruits and having their children sell them to city dwellers. Sadly, the data suffers from divergence in measurements and numerous gaps. Normally sold by the barrique (barrel), apples could also be sold the cent livres, the minot, the pochetée or the baril (which translates into barrel but was a different unit of measurement than the barrique). In addition, we don't know how many apples there were per barrique. For the year 1705, I had two observations where 100 livres of apples sold for 60 sols which a barrique sold for 600 sols-suggesting that there are 1000 livres per barrique. That number seems implausibly high, but other researchers might know the answer and find something to do with it.

Figure A3.4: Price of apples (in livres per barrique)

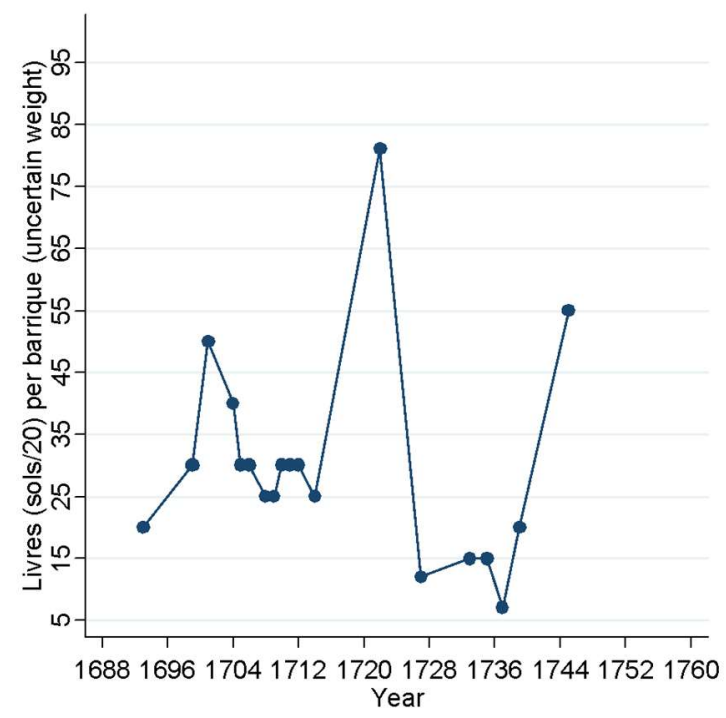


Middlings (gru): Wheat middlings, known as gru, were a common feed item for farm animals. It also plays an underappreciated role in the economy of New France. Milling activities, from which middlings would become available, were highly regulated. First of all, the seigneur had monopoly rights over milling. Secondly, they may have held monopoly, but they were subjected to price controls on the toll they could charge to grain growers. They only keep $1 / 14^{\text {th }}$ of all the grain brought to the mill-a rate well below everything observed in North America at the time. Thirdly, they were obligated to operate a mill under threat of losing their seigneurial rights. Fourth, the price of bread was also subjected to price controls. Elsewhere, I have argued that this price control made it onerous to operate a mill, but that seigneurs could recuperate a large part of their losses. This is because they were two sizable loopholes. Price controls did not apply on flour meant for exports and no price controls existed on son (bran) and gru (middlings). Peasants would bring their grain to the mill and would receive very coarse flour for what they got back. The incentive of the seigneur was to cut quality there as much as possible. The toll which was exacted as the revenue of the seigneur would, however, follow a different path. It would be transformed into finer flour which could be exported on foreign markets. In the process of sifting flour to make it finer, seigneurs would collect bran, germ and middlings which they could then sell at unregulated prices. Since obtaining bran and germs could only occur through proper sifting at the mill, the landlords had a virtual monopoly over these products. Landlords gained important profits by increasing the price of bran and germs which tended to be used as feed for livestock. However, I could not integrate it inside my price index because of gaps.

This line of reasoning was expanded in a separate paper that was not included in this dissertation. Co-authored with Alexis Lacombe, this paper was published by the Agricultural History Review under the title of "Why was flour of poor quality? The impact of seigneurial laws and price controls on flour in Quebec during the colonial era". 445

${ }^{445}$ Vincent Geloso and Alexis Lacombe. 2016. "Why was flour of poor quality? The impact of seigneurial laws and price controls on flour in Quebec during the colonial era", Agricultural History Review, Vol.64, no.2, pp.181-195. 
Figure A3.5: Price of gru (middlings) (in livres per minot)

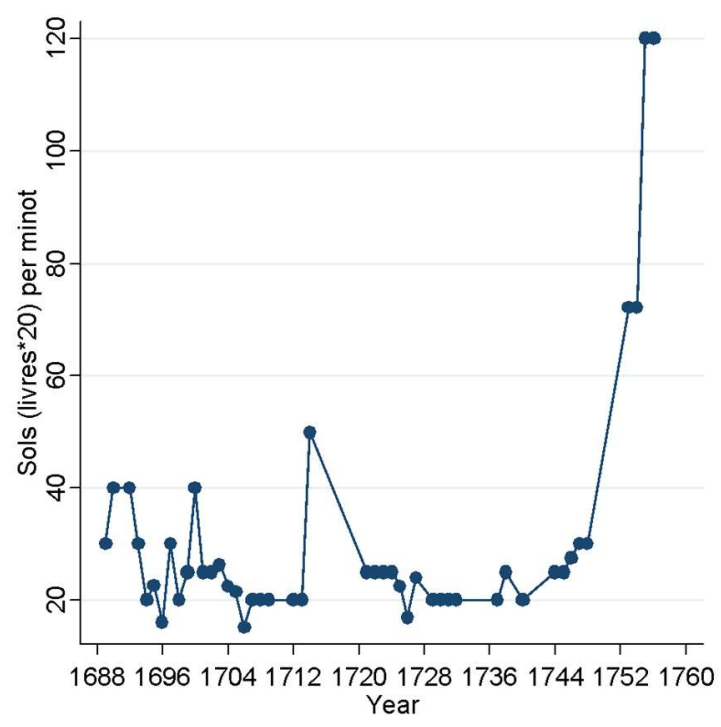


Poudre (gunpowder) and plomb (lead): gunpowder was sold by the livre (489.5 grams). Up to 1721 , it was very reliably reported and numerous observations each year. After 1721, no observations appear until 1746. However, the price of gunpowder up to 1721 can be used for other researchers interested in the fur trade. Since it was heavily traded for furs, it could be used to measure terms of trade. Plomb referred to the munition and more observations are available and refers to lead.

Figure A3.6. Price of gunpowder (in livres per livre of 489.5 grams)

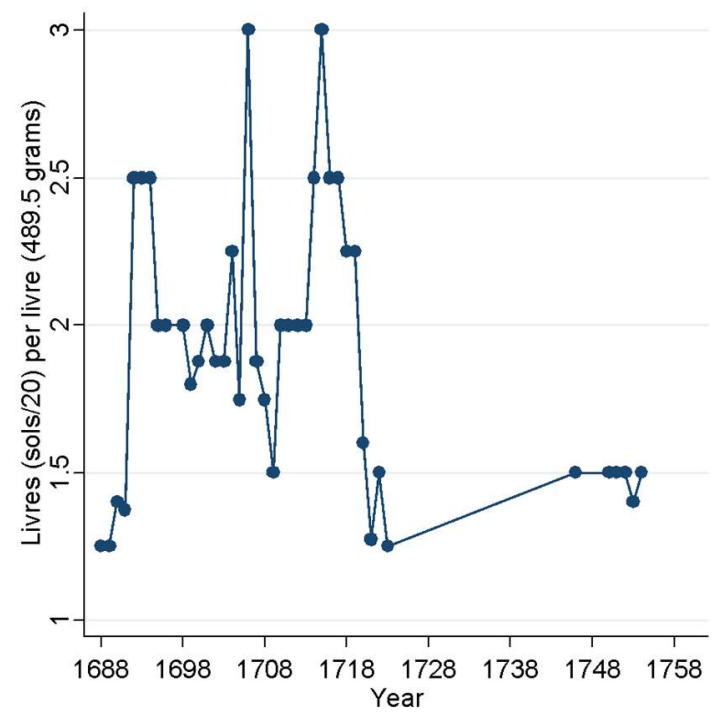

Figure A3.7. Price of lead (in livres per livre of 489.5 grams)

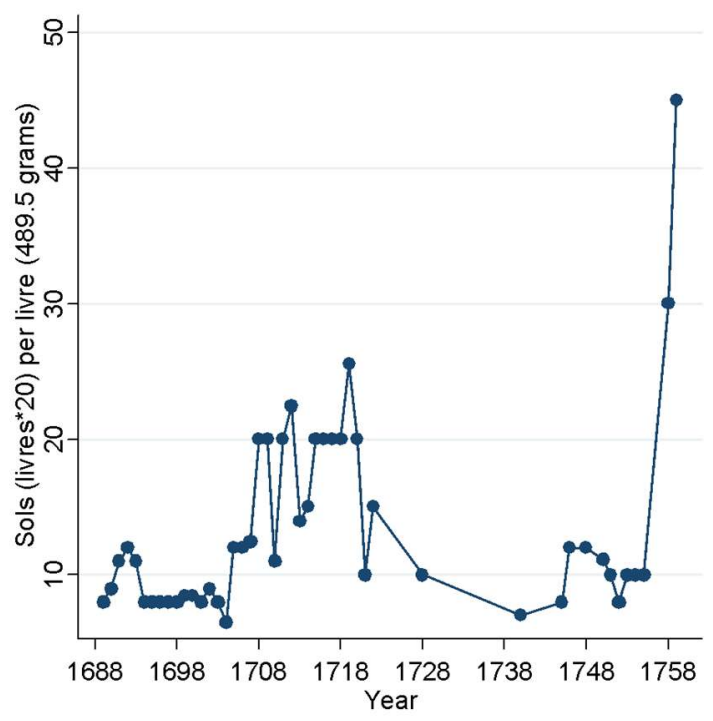


Raisins (grapes): Grapes are not well suited for the climates of Quebec except in certain microclimates along the US-Canada border south of Montreal. As a result, any mentions of grapes found during the colonial era would refer to imported goods. Sadly, there were too many gaps to use it.

Figure A3.8. Price of grapes (in livres per livre of 489.5 grams)

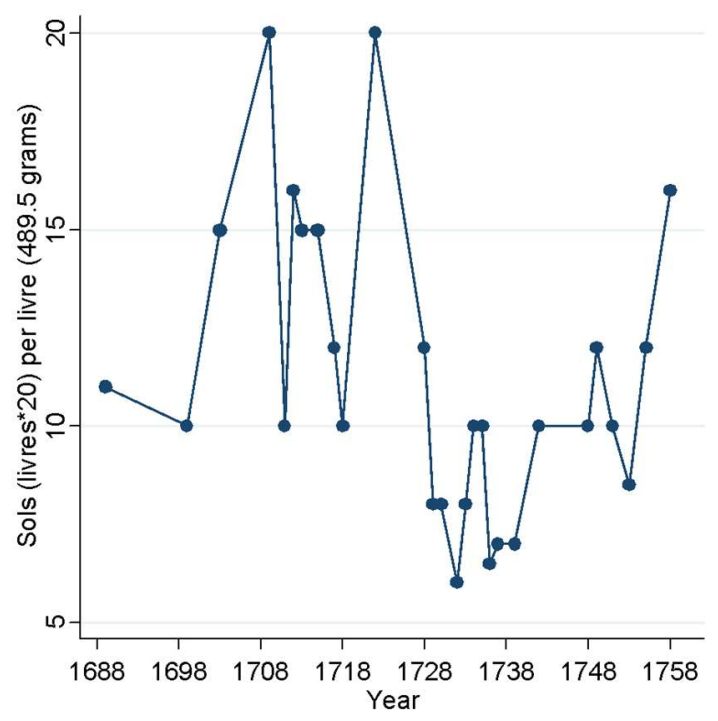


Papier (paper): Paper was a purely imported until 1803. It was in 1803 that the first paper mill was established northwest of Montreal. Prior to that date, paper had to be imported. It was generally sold by the main or the rame (20 mains per rame).

Figure A3.9. Price of paper (sols per main)

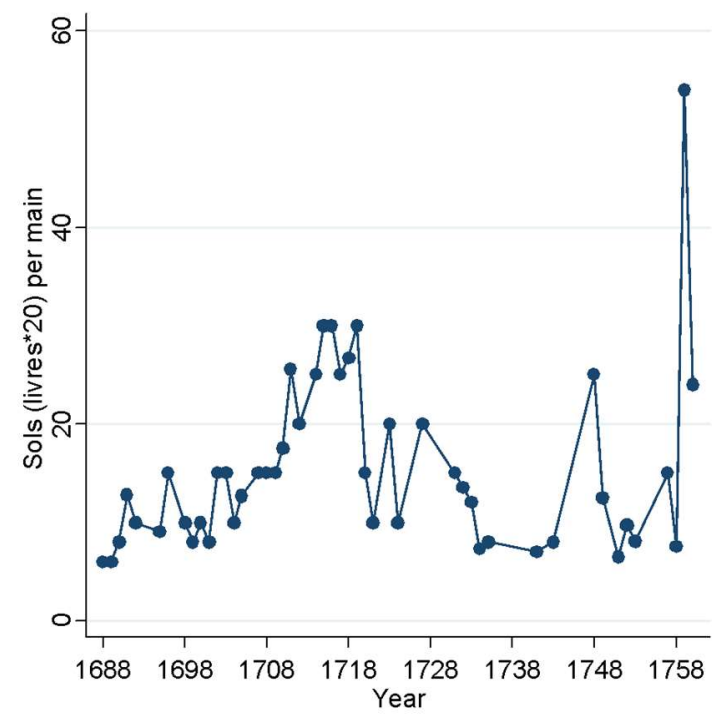


Mélasse (molasses): Molasses would have been a tremendously useful item to include in the data. The problem is that the reporting units are questionable. Prices were reported in barriques (barrels) or pots. The problem is that barrels were not always plenty and thus the price did not always correspond with the level per pot (by wide margins).

Figure A3.10. Price of molasses (in sols per pot or livres per barrique)

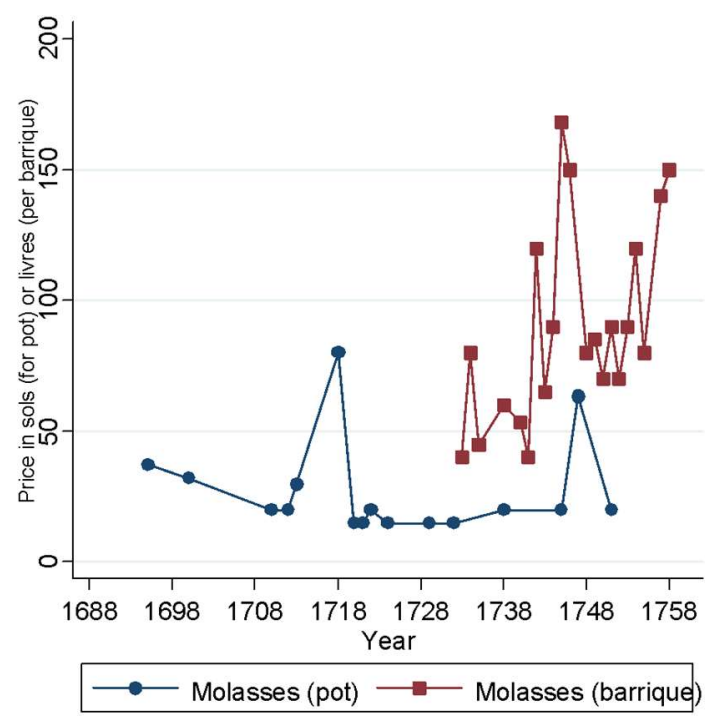


Orge (barley): Barley was never a predominant crop; little use could come from it. Some researchers could have a better idea of what to do with it.

Figure A3.11. Price of barley (sols per minot)

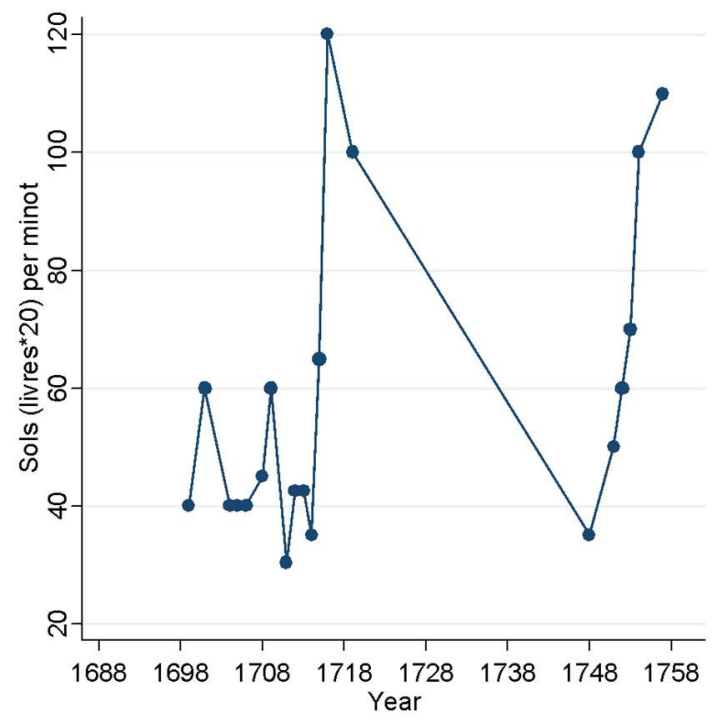


Riz (rice): Rice was an imported item sold by the livre. It was mostly consumed by religious officials. The average citizen was not a regular consumer of this item.

Figure A3.11. Price of rice (sols per livre of 489.5 grams)

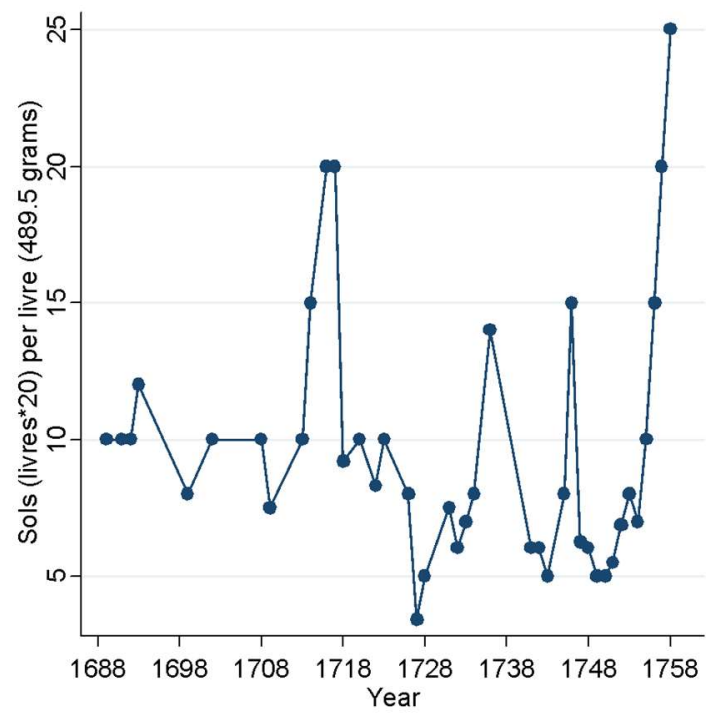


Farm Animals: Any future in-depth of the structures of the economy of New France would rely greatly on the use of prices for capital inputs, notably in agriculture. This is particularly important since capital goods tended to be imported. The first farm animals were quite prohibitive to import and likely made any form of capital intensive farming prohibitively expensive. The issue is mostly with the type of animals. For example, boeufs (beefs) had numerous purposes like travail (work-oxen) or à boucherie (for slaughter-steers). The same applied for cows-à lait (milk cows) and à boucherie. Horses, veals, chickens and sheeps were also found. Prices of swine were found, but there were large problems in quality (cochon à lait, petit cochon, cochon gras, vieux cochon, cochon malade) and I ignored them.

Figure A3.12. Price per animal (livres per animal), horses, oxen, slaughter beefs, slaughter cows and milk cows

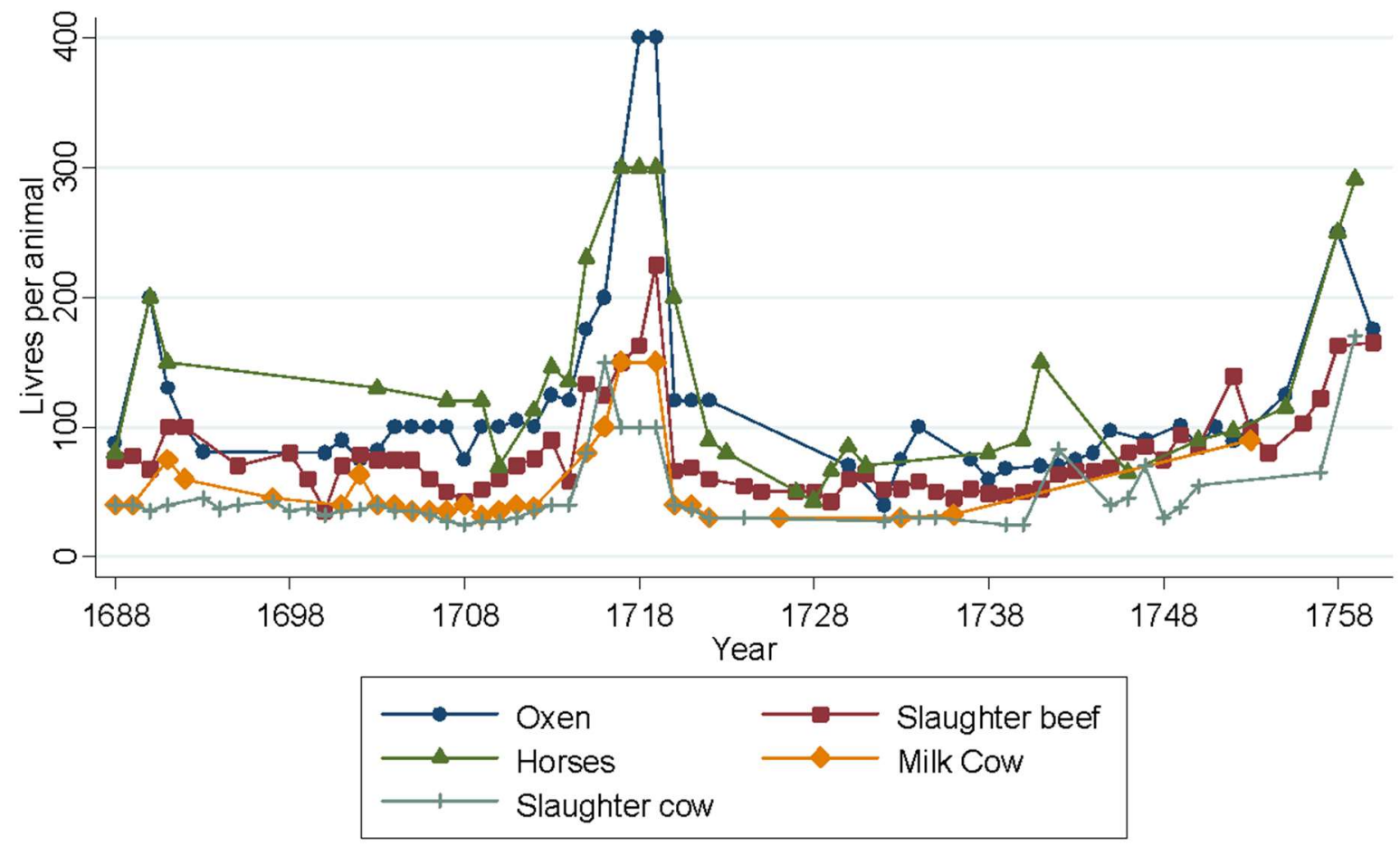


Figure A3.13. Price per animal (livres per animal and sols per chicken), sheep, chickens and veals

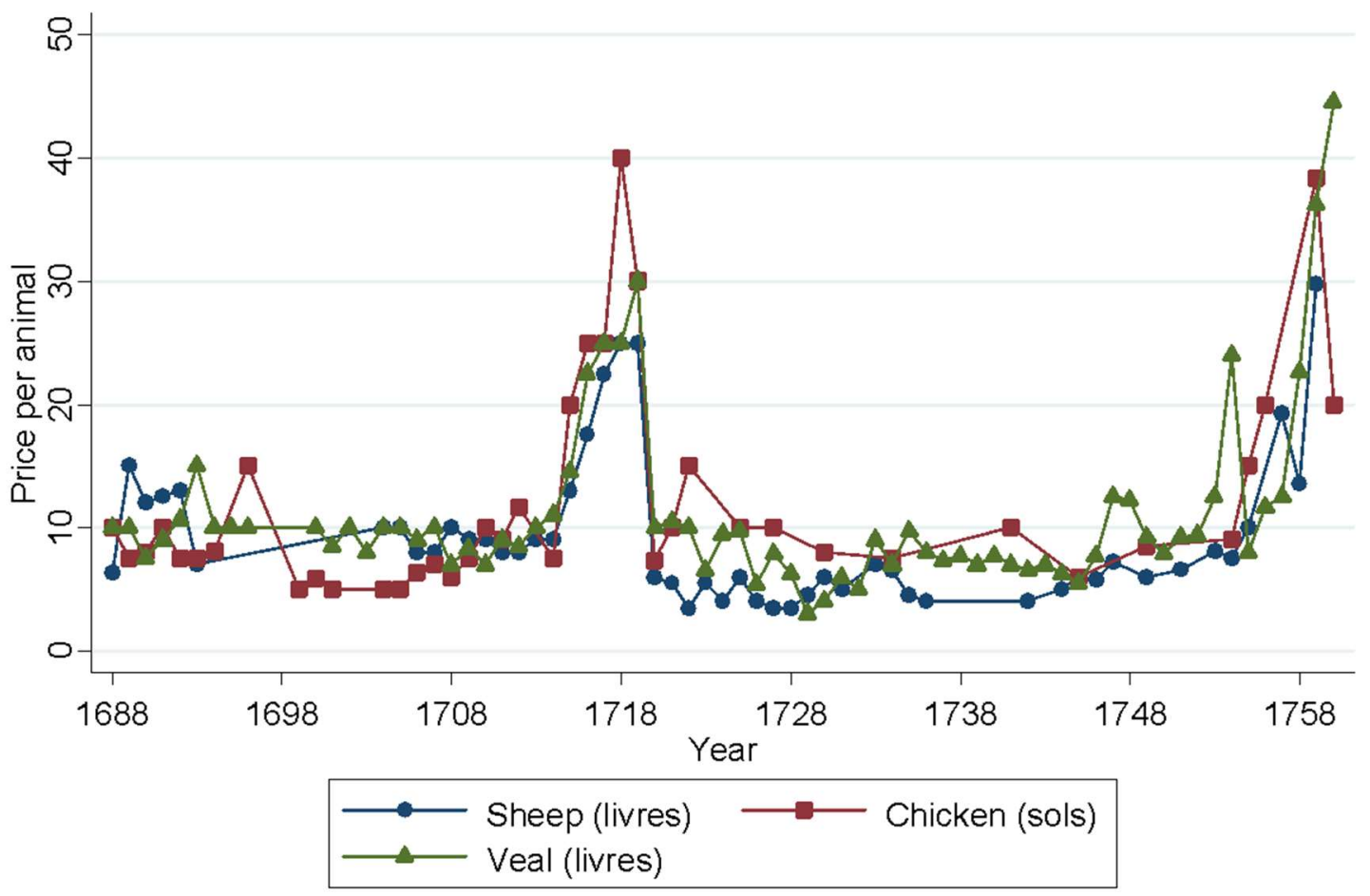




\section{APPENDIX 2: DETAILS OF WAGES WITH ADDITIONAL INFORMATION}




\section{Wages sources}

The wage rates collected from the religious congregations in Quebec City were of high quality. In most instances, the activity was specified with the name and the rate and - in many instances - the number of days worked. The great advantage is that the Séminaire and the Ursulines took great care in separating in-kind payments from monetary payments. Hence, a worker would be paid "1 livre par jour et une paire de souliers" (paid 1 livre per day and one paire of shoes). Or, a worker could be paid et nourry (and fed). In some instances, the daily cost of food was mentioned. As a result, there is very little doubt about the quality of the wages.

In addition, the tasks performed were generally well detailed. In most instances, the wage rates mentioned specify the nature of the trade in which the individual was engaged. It is important to note however that sometimes, a menuisier (carpenter) could be hired to work aux foins (in the fields) for tasks that had little to do with their area of specialty. Hence, I sometimes recorded more than one wage observation that pertained to one individual in a given year but for numerous different tasks. In some cases, annual wages were mentioned but not the trade. In that instance it was possible to cross-reference with the index of names at the Séminaire's archives in order to pinpoint the trade of the individual. Keeping notes of the names of the individuals also allowed filling in some gaps about trades and occupations. ${ }^{446}$ In some instances, the surnames sometimes contained the information to fill the gaps. Table A2.1 shows how some surnames were indicative of the trade occupied.

Table A2.1. Examples of name with trades

\begin{tabular}{cc} 
Surname & Trade \\
\hline Masson or Macon & Mason \\
Charpentier & Carpenter \\
Meunier & Miller \\
Charet & Transporter / Wheelwright (a charretier was the trade \\
& of owning a cart to transport resources) \\
\hline
\end{tabular}

\footnotetext{
446 This can be seen in the nature of the tasks individuals were contracted for. In more than $80 \%$ of cases, the unskilled wage rates specified the nature of the work contracted. In most of the instances remaining, the wage rates were reported to another wage rate whose task was reported and also had the exact same rate. The works were for récoltes (harvesting), foins (feeding livestock or working in the fields), étable (working at the stable), fauchage (mowing), à la ferme (at the farm), aux clotures (enclosing), défrichages (land clearing), aux fossés (ditch digging) and au vacher (cowherding). The non-agricultural unskilled work was for entreprise de bois or bûcher du bois (sawing wood) and pour peinturer (for painting). These two tasks had wages identical to those in agriculture. The only difference for unskilled was for ouvriers (workmen) generally on very heavy manual work like building roads. Bairoch (1989. "Wages as an Indicator of Gross National Product" in eds. Peter Scholliers, Real Wages in 19 $9^{\text {th }}$ and $20^{\text {th }}$ century Europe: Historical and Comparative Perspectives. New York: Berg Publishing, pp.51-60.) pointed out that when workmen were hired for heavy manual work (like ouvriers), they generally earned a premium which may bias the data. However, in this case the issue is limited. Only three observations were related to ouvriers and their wages were not out of line with those of other unskilled workers. As a result, I kept them as they were.
} 


\section{Interpolation method}

The data on the unskilled wages and carpenters contained missing values, which were interpolated using the MATLAB software and the "iterpl" function from the set of the 1-D interpolation methods. The option "spline" was used for the method of interpolation. This option represents the piecewise cubic spline interpolation method as in de Boor using not-a-knot end conditions. The usage of the piecewise treatment helps to avoid the Runge's phenomenon of oscillation of polynomials of higher degrees and decreases the interpolation error compared to linear or simple polynomial interpolation methods. Carl de Boor. 2001. A Practical Guide to Splines (Revised Edition), New York: Springer, p.23. The interpolation has been kindly provided thanks to the help of Vadim Kufenko of Hohenheim University's department of economics. However, for carpenter wages, the results for 1688 and 1689 were quite strange-yielding very high values. The value observed for 1690 was attributed to these. The same problem was observed for 1688 with unskilled wages. I attributed the 1689 value. Table A.2.3 shows the missing observations for carpenters and unskilled workers.

Table A2.3. Years missing

Types of wages

Unskilled (90\% coverage)

Charpentier (58\% coverage)
Missing observations

$1688,1725,1728,1729,1732,1756,1757,1760$ 1688 to $1690,1708,1711,1712,1714$ to 1716.1725 to 1730,1734 to 1738,1743 to $1746,1750,1754$ to 1757 , 
APPENDIX 3: LINKING OUR PRICES TO THE PAQUET-WALLOT PRICE INDEX 


\section{The Paquet-Wallot price index as a measure of the economy's movement}

This thesis represented the first step in an effort to craft empirical datasets for Canada from 1688 to 1860 was mainly concerned with getting "right" the period from 1688 to 1760 before moving on to the era of British rule. However, it is possible to link the price index created in part 3 of this thesis with the index created by Gilles Paquet and Jean-Pierre Wallot in 1998. ${ }^{447}$ Their index covered the period from 1760 to 1860 .

In their work, Paquet and Wallot took the prices for 20 commodities in Quebec City and created a non-weighted price index of their price relatives. Many economic historians have been skeptical about their price index because of that particular feature. To be fair, Paquet and Wallot did not intend to use as a deflator for the cost of living as much as an indicator of how prices moved in broad brushes. This is why they referred to the "polyphony" of prices-meaning that price movements would convey the information about the broad direction of the economy of Lower Canada. Their stated intent is reminiscent of Earl Hamilton's assessment of the price history literature when he stated that:

Price historians have not infrequently discovered, to their dismay, at the end of a quarter of century or more of assiduous labor that previously compiled index numbers based on the quotations of a very few articles-sometimes two or three-haphazardly thrown together from heterogeneous sources for widely scattered years have disclosed the trend of prices as accurately as their laboriously constructed indices from homogeneous series embracing monthly or quarterly quotations for dozens of commodities. ${ }^{448}$

The effort advanced by Paquet and Wallot follows in spirit the claim made by Hamilton. Using equal weights for all the price relatives probably provides a poor deflator for wages, incomes and the price of particular commodities. However, the broad trend of prices does tell us the story of what was occurring in the economy as a whole. John J. McCusker made a similar claim in 1992 when he asserted that despite not being "necessarily well suited" for this task, fluctuations in the performance of an economy are well displayed by a commodity price index "as if [such an index] ran parallel to the movement of the gross national product". ${ }^{449}$ Given their stated (and limited)

\footnotetext{
${ }^{447}$ Gilles Paquet and Jean-Pierre Wallot. 1998. "Some Price Indexes for Quebec and Montréal (1760-1913)", Histoire Sociale / Social History, vol.31, no.62, pp.281-320.

${ }^{448}$ Earl Hamilton. 1944. "Use and misuse of price history", Journal of Economic History, Vol.4, no. S1, p.50.

449 John J. McCusker. 1992. How Much Is That in Real Money? : A Historical Price Index for Use as a Deflator of Money Values in the Economy of the United States. Worcester, MA: American Antiquarian Society, p.310.
} 
objective, there is value in extrapolating their index backward in time. This is what this annex does. $^{450}$

\section{Constructing the index from 1688 to 1760.}

As mentioned earlier, there were 27 goods that could be used reliably from 1688 to $1740 .{ }^{451}$ After 1740, that number falls to 20 , and in this period. In addition to this, as mentioned before, two indexes needed to be constructed. This first method of calculation was one in which the researcher merely used a Laspeyres price index, as described in Formula I, with equal weights for all goods.

$$
\text { I) } \quad P=\frac{\sum\left(P_{t} * Q_{o}\right)}{\sum\left(P_{0} * Q_{o}\right)}
$$

Formula 2, below, illustrates the basket of 27 commodities and how it was calculated, whereas Formula 3 indicates the limited price index in order to cover the entire period of French rule.

$$
\begin{aligned}
& \text { II) } \quad P(1688 \text { to } 1740-27 \text { goods })=\frac{\sum\left(P_{t} * 3.70370 \%\right)}{\sum\left(P_{0} * 3.70370 \%\right)} \\
& \text { III) } \quad P(1688 \text { to } 1760-21 \text { goods })=\frac{\sum\left(P_{t}^{*} * 4.7619 \%\right)}{\sum\left(P_{0} * 4.7619 \%\right)}
\end{aligned}
$$

These initial price indexes provided the researcher with a first glimpse of how prices moved in New France. However, that said, the researcher was aware of the limitations that come with such indexes. They do not truly reflect the cost of living because the assignment of equal weights

450 This index has already served for another paper: see Vincent Geloso and Vadim Kufenko. 2015. "Malthusian pressures: empirical evidence from a frontier economy", Journal of Population Research, Vol. 32, no. 3-4, pp.263283.

451 The 27 goods are: wheat, flour, hay, bran, oats, eggs, socks, salt, codfish, peas, tobacco, nails, shoes, savage shoes, lighting oil, firewood, wood planks, beef, butter, lard, religious candles, wine, spirits, cloth, olive oil, soap and eels. The 21 goods are: the same as the 27 goods minus bran, nails, savage shoes, olive oil, religious candles and tobacco. Now, it is important to note here that that I have not used candles as interpolated for Chapter 3 of this thesis. This is a result of the chronology of the production of this dissertation. Initially, I had opted to make this appendix into the main chapter on the price index in order to link up with Paquet and Wallot. At that point, I had not yet decided to produce the chapter on welfare ratios (see Chapter 4). As a result, I did not consider the absence of illuminates in the period from 1740 to 1760 to be a problem. I was dissuaded to do so by my colleagues to do this limited price index as a chapter in my thesis. They argued, rightly, that there was great value in producing a linkage with the Paquet-Wallot index but that it was not worth a doctoral dissertation. However, in the meanwhile I had already produced that linkage and used it for a paper which has been accepted for publication (at the time of writing this) in the Journal of Population Research (co-authored with Vadim Kufenko). The data presented in that paper is the one contained in this appendix. However, we can reassure readers that since then, we have replicated our results with the index using the interpolated price of candles derived (see appendix 1). The results contained in our article in the Journal of Population Research are not affected. It was a minor change, however since I quoted an earlier version of my dissertation (which was presented at the Economic and Business History Society meeting in Manchester in May 2014 and at the Canadian Network for Economic History in October 2014) in that article, I felt that I had to put this appendix here as it was used in my article in order to insure replicability. 
to all goods gives too much importance to certain goods. For example, it is unlikely that soap represented close to $3.85 \%$ of the budget of poorer households or that olive oil commanded a similar share of budget expenditures. Figure A3.1 illustrates the result of this crude index of prices. From 1688 to 1740 , there were 1,431 possible data points for the above-mentioned 27 goods the researcher for this project collected. Out of these data points, only 48 were missing, or $3.35 \%$ of the total. Most came from tobacco ( 8 missing), while the rest were evenly distributed. From 1740 to 1760 -years which were marked by war and inflation as a result of monetary policy - there were 20 goods which were reliably collected and which represent a potential for 420 observations. Out of these, 70 data points were missing and needed to be imputed, or $16.7 \%$ of the total in this 21-year period.

Fig A.2.1. Price index $(1720-1724=100)$ using different basket sizes on log-scale

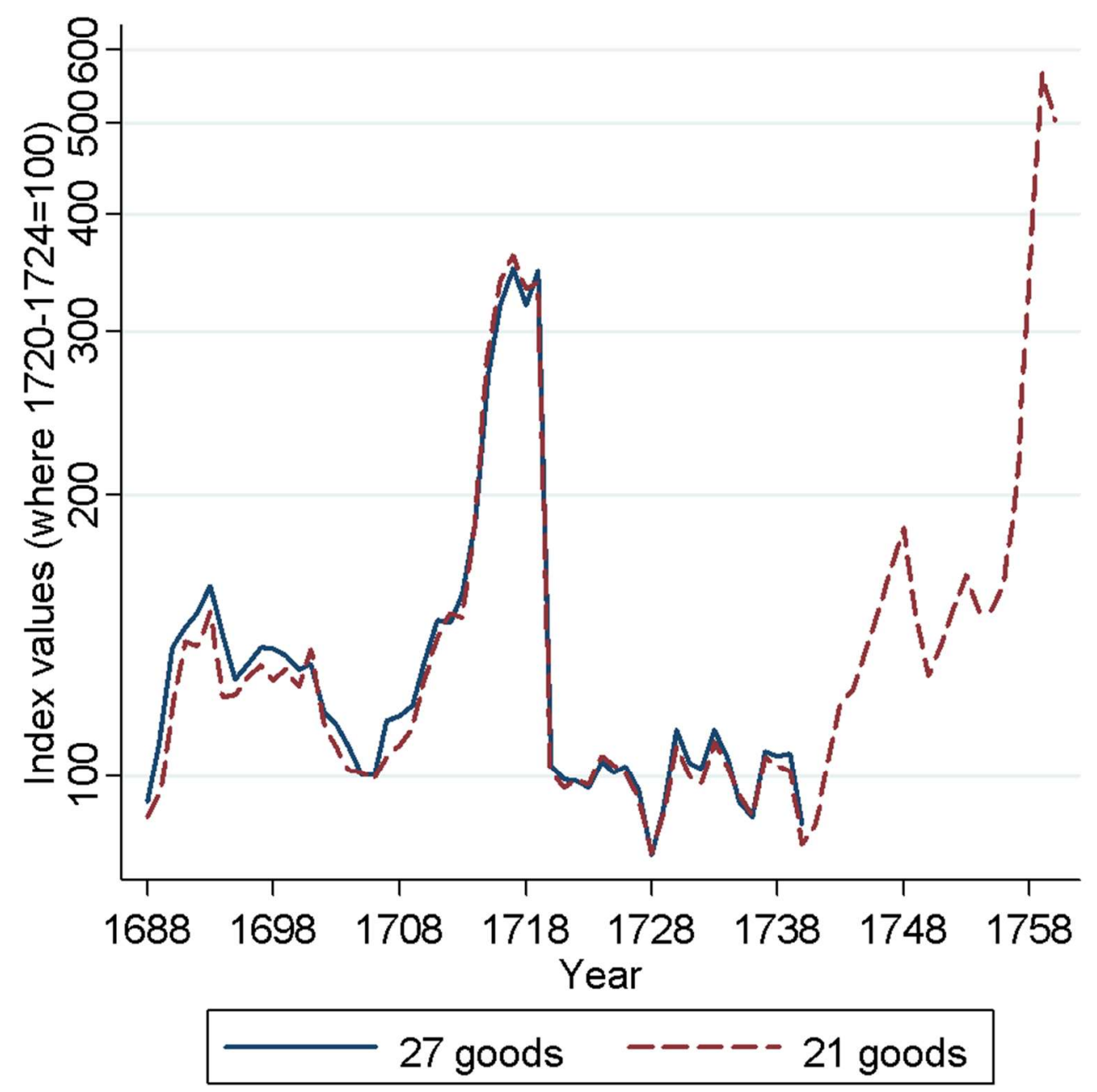




\section{Linking with Paquet and Wallot}

As one can see, prices behave similarly, regardless of the size of the basket, which indicates that it is safe to link the 20 goods index with that of Paquet and Wallot from 1760 to 1860. To accomplish the linkages with the Paquet and Wallot index, data from the Séminaire de Québec and the Ursulines had to be collected past 1760. The first year in which the twenty commodities reported prices was 1762. The two indexes were linked to that year and Figure A2.2

Figure A2.2. Merging the Geloso and Paquet-Wallot Price Indexes, 1688 to 1860 (1762=100)

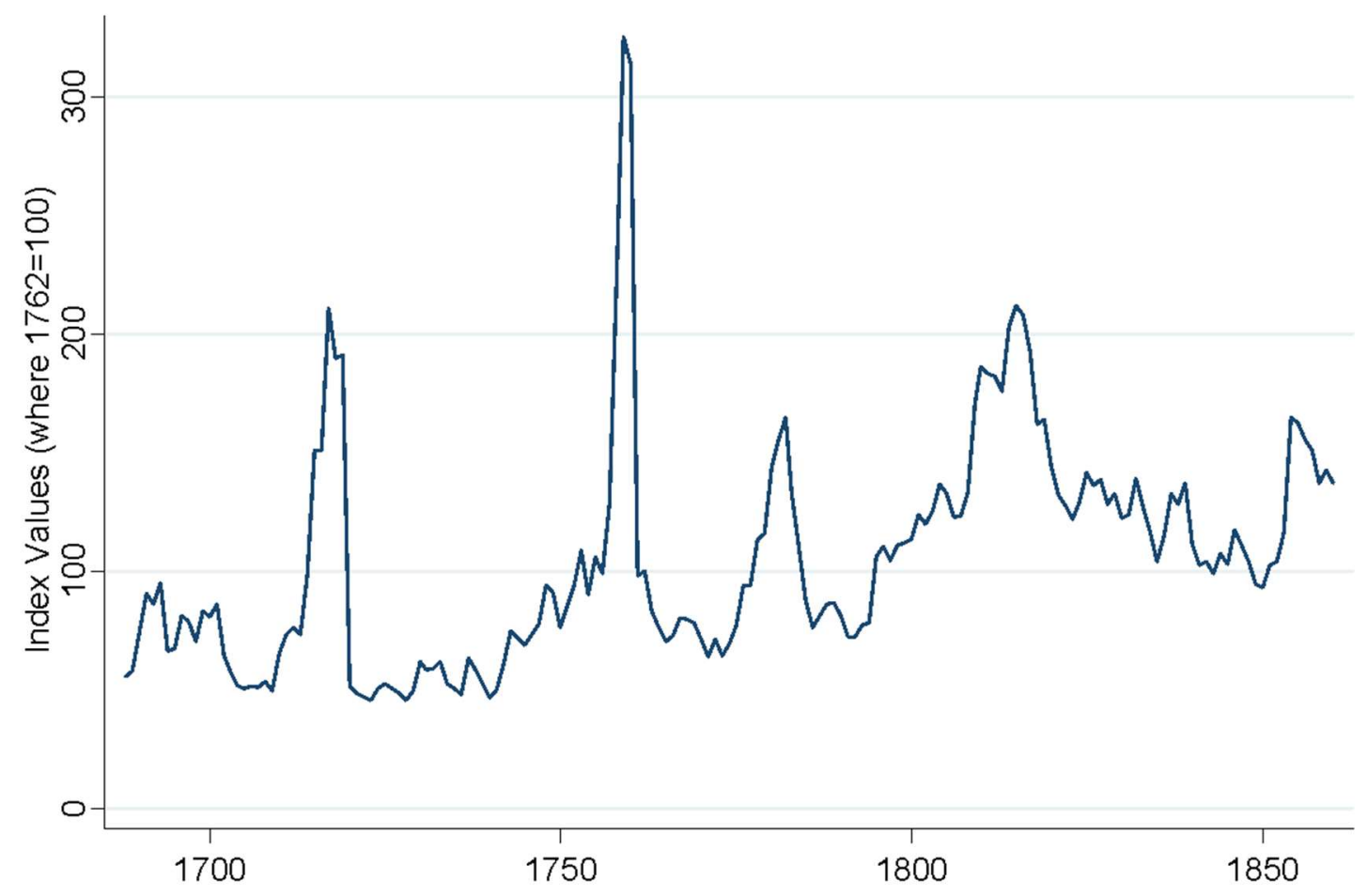

In their 2007 compendium of articles written together, Paquet and Wallot provided the readers with their analysis of the price movements. Their analysis was based on simple reasoning of aggregate supply and aggregate demand in combination with monetary shocks. In their opinions, real factors mattered more. Most of the price fluctuations were the result of supply shocks. In their period of interest, this seemed like a reasonable claim given the price increases observed from 1775 to 1783 (corresponding to the American revolutionary war and the invasion of Quebec), from 1792 to 1815 (corresponding to the French wars and the 1812 invasion of Canada by the Americans) and from 1854 to 1856 (corresponding to the Crimean war). All of these periods do correspond with supply shocks caused by international conflicts or outright invasions of Canada. 
In their opinion, monetary shocks did not present a problem for the colony. ${ }^{452}$ However, when I moved backwards to include the era of New France, this was not the case anymore. The two largest episodes of price increases during the New France are either exclusively monetary phenomenas or shared real and monetary causes.

The price increase from 1705 to 1719 occurs during the first experiment of the colonial administration with paper money. During that period, the colonial administration issued claims on future coin shipments on the back of playing cards signed by the governor. These notes initially circulated at a discount because they were not given legal tender status until 1705. After 1705, the enforcement of legal tender - combined with the expansion of the money supply-led to important price increases in the colony. This price increase, the largest part of which occurred after 1714, took place in an era where New France was at peace. Hence, that episode is solely monetary. The second episode, which occurred from 1740 to 1760, took place in part because of real factorscrop failures and wars - but also in part because of the resumption in the 1740s of a scheme of paper money similar to that in the 1710 s.

Hence, while Paquet and Wallot find the story of an economy mainly affected by real shocks after 1760 , the index prior to 1760 tells us a mixed story of monetary and real factors. This suggests that future research should be concerned with the study of monetary policy over time. Indeed, if there are very few monetary shocks past 1760 while these dominate prior to 1760 , questioning the role of monetary policy in the economic development of the colony is crucial.

However, Paquet and Wallot had only five non-agricultural goods and fewer imported goods. Basically, their price indexes should be seen as an "agricultural price index". My price index contains a wider array of non-agricultural price which can be used to capturer a broader array of goods.

\section{Conclusion}

This appendix had a very limited aim: linking up the data prior to 1760 to the index of Paquet and Wallot. Including such a section in the main section of this thesis would have diverted attention from the importance of designing a proper price index with weights. However, since linking with Paquet and Wallot was not void of interest - in terms of identifying the broad movements of the economy - there was value in generating this annex. At the very least, it will help researchers identify key moments in Quebec's economic history.

\footnotetext{
452 Gilles Paquet and Jean-Pierre Wallot. 2007. Un Québec Moderne, 1760-1840 : Essai d'histoire économique et social. Montréal: Éditions Huburtise HMH, p.166-169.
} 
APPENDIX 4: INDEX OF PRICES AND WAGES 
Table A4.1: Index number for prices of goods, 1720-1724=1

\begin{tabular}{|c|c|c|c|c|c|c|c|c|}
\hline & WHEAT & FIREWOOD & $\begin{array}{c}\text { WOOD } \\
\text { PLANKS }\end{array}$ & $\begin{array}{c}\text { FRENCH } \\
\text { SHOES }\end{array}$ & $\begin{array}{c}\text { SAVAGE } \\
\text { SHOES }\end{array}$ & SPIRITS & WINE & OATS \\
\hline 1688 & 1.30 & 0.84 & 1.48 & 0.65 & 1.04 & 0.88 & 0.45 & 1.11 \\
\hline 1689 & 1.30 & 0.74 & 1.50 & 0.65 & 1.04 & 0.84 & 0.58 & 1.11 \\
\hline 1690 & 2.25 & 1.06 & 1.32 & 0.74 & 1.46 & 0.95 & 0.56 & 1.39 \\
\hline 1691 & 2.80 & 0.88 & 1.64 & 0.77 & 1.25 & 0.95 & 0.56 & 2.22 \\
\hline 1692 & 2.53 & 0.93 & 1.40 & 0.73 & 1.04 & 0.84 & 0.75 & 2.78 \\
\hline 1693 & 2.93 & 1.04 & 1.62 & 0.77 & 1.25 & 1.16 & 0.86 & 2.22 \\
\hline 1694 & 1.30 & 0.99 & 1.44 & 0.65 & 1.25 & 1.58 & 0.88 & 1.67 \\
\hline 1695 & 0.90 & 1.58 & 1.64 & 0.89 & 1.46 & 1.58 & 0.56 & 1.67 \\
\hline 1696 & 1.53 & 0.93 & 1.32 & 0.89 & 1.35 & 0.99 & 0.58 & 1.56 \\
\hline 1697 & 1.60 & 0.93 & 1.32 & 0.89 & 0.94 & 1.11 & 0.75 & 1.94 \\
\hline 1698 & 1.20 & 0.98 & 1.32 & 0.92 & 1.56 & 0.99 & 1.41 & 2.22 \\
\hline 1699 & 1.64 & 1.02 & 2.14 & 0.83 & 1.15 & 0.98 & 0.75 & 2.22 \\
\hline 1700 & 1.20 & 1.02 & 1.48 & 0.76 & 1.25 & 0.95 & 1.16 & 1.94 \\
\hline 1701 & 2.05 & 1.61 & 1.48 & 0.77 & 1.30 & 0.63 & 1.13 & 2.22 \\
\hline 1702 & 1.33 & 1.44 & 0.82 & 0.89 & 1.00 & 1.09 & 0.96 & 1.67 \\
\hline 1703 & 0.77 & 1.01 & 1.32 & 0.83 & 1.18 & 1.68 & 1.13 & 1.25 \\
\hline 1704 & 0.75 & 1.18 & 1.15 & 0.97 & 1.11 & 1.09 & 1.03 & 1.06 \\
\hline 1705 & 0.71 & 1.32 & 1.15 & 0.92 & 1.04 & 1.26 & 1.31 & 1.06 \\
\hline 1706 & 0.83 & 1.46 & 1.64 & 0.59 & 1.46 & 0.95 & 0.94 & 0.83 \\
\hline 1707 & 1.00 & 0.93 & 0.99 & 0.83 & 2.50 & 0.84 & 0.98 & 1.11 \\
\hline 1708 & 1.30 & 0.92 & 0.99 & 0.71 & 1.67 & 0.95 & 1.31 & 1.11 \\
\hline 1709 & 1.14 & 0.88 & 0.79 & 1.43 & 1.67 & 1.05 & 1.63 & 1.11 \\
\hline 1710 & 1.40 & 1.40 & 0.99 & 0.89 & 1.92 & 1.76 & 1.50 & 1.11 \\
\hline 1711 & 1.28 & 0.86 & 1.32 & 1.01 & 1.77 & 2.74 & 2.53 & 1.39 \\
\hline 1712 & 0.90 & 1.06 & 1.08 & 0.89 & 1.67 & 1.89 & 1.78 & 1.39 \\
\hline 1713 & 1.37 & 1.44 & 1.32 & 0.81 & 1.67 & 1.58 & 1.69 & 1.53 \\
\hline 1714 & 1.70 & 1.91 & 1.20 & 1.19 & 2.08 & 2.11 & 1.69 & 2.22 \\
\hline 1715 & 3.19 & 1.86 & 2.34 & 1.31 & 2.71 & 2.95 & 3.00 & 3.33 \\
\hline 1716 & 3.19 & 2.57 & 2.79 & 2.44 & 2.50 & 5.05 & 5.25 & 2.78 \\
\hline 1717 & 3.79 & 2.00 & 1.97 & 2.02 & 2.92 & 4.45 & 4.00 & 3.33 \\
\hline 1718 & 3.19 & 2.30 & 3.29 & 2.26 & 2.71 & 3.79 & 3.00 & 3.33 \\
\hline 1719 & 2.40 & 2.02 & 3.18 & 2.02 & 2.50 & 3.79 & 3.38 & 3.33 \\
\hline 1720 & 1.03 & 0.93 & 1.23 & 1.13 & 0.83 & 0.95 & 0.75 & 0.83 \\
\hline 1721 & 0.90 & 1.02 & 0.99 & 1.10 & 1.04 & 0.95 & 0.87 & 0.83 \\
\hline 1722 & 0.97 & 0.86 & 0.91 & 0.98 & 0.83 & 0.95 & 1.06 & 1.11 \\
\hline 1723 & 0.90 & 1.07 & 0.89 & 0.82 & 1.04 & 1.05 & 1.38 & 0.97 \\
\hline 1724 & 1.20 & 1.12 & 0.99 & 0.97 & 1.25 & 1.11 & 0.94 & 1.25 \\
\hline 1725 & 1.20 & 1.19 & 0.99 & 0.83 & 1.04 & 1.16 & 0.50 & 1.11 \\
\hline 1726 & 0.77 & 1.44 & 1.32 & 0.71 & 1.32 & 1.26 & 1.05 & 0.97 \\
\hline
\end{tabular}


Table A4.1: Index number for prices of goods, 1720-1724=1 (continued)

\begin{tabular}{|c|c|c|c|c|c|c|c|c|}
\hline & WHEAT & FIREWOOD & $\begin{array}{l}\text { WOOD } \\
\text { PLANKS }\end{array}$ & $\begin{array}{c}\text { FRENCH } \\
\text { SHOES }\end{array}$ & $\begin{array}{l}\text { SAVAGE } \\
\text { SHOES }\end{array}$ & SPIRITS & WINE & OATS \\
\hline 1727 & 1.15 & 1.43 & 0.99 & 0.74 & 1.25 & 0.84 & 1.05 & 0.97 \\
\hline 1728 & 0.80 & 1.18 & 0.82 & 0.83 & 0.93 & 0.43 & 0.50 & 1.11 \\
\hline 1729 & 1.00 & 1.58 & 0.99 & 0.71 & 1.25 & 0.36 & 0.94 & 1.11 \\
\hline 1730 & 1.20 & 1.40 & 1.32 & 0.68 & 1.25 & 0.84 & 0.94 & 1.00 \\
\hline 1731 & 0.98 & 1.12 & 1.32 & 0.65 & 1.25 & 0.93 & 0.75 & 1.11 \\
\hline 1732 & 1.00 & 1.35 & 0.99 & 0.71 & 1.04 & 0.63 & 0.45 & 1.11 \\
\hline 1733 & 1.20 & 1.86 & 1.26 & 0.62 & 1.25 & 0.63 & 0.75 & 1.39 \\
\hline 1734 & 1.00 & 1.32 & 1.29 & 0.56 & 1.15 & 0.71 & 0.84 & 1.11 \\
\hline 1735 & 1.01 & 1.50 & 1.15 & 0.59 & 1.04 & 0.45 & 0.83 & 1.17 \\
\hline 1736 & 0.74 & 1.43 & 0.82 & 0.59 & 1.15 & 0.53 & 0.56 & 1.06 \\
\hline 1737 & 1.20 & 1.68 & 0.95 & 0.59 & 1.25 & 0.58 & 0.75 & 1.11 \\
\hline 1738 & 1.21 & 1.58 & 0.82 & 0.53 & 1.04 & 0.58 & 0.84 & 1.11 \\
\hline 1739 & 0.90 & 1.61 & 1.07 & 0.61 & 1.29 & 0.63 & 1.13 & 1.11 \\
\hline 1740 & 0.85 & 1.68 & 1.15 & 0.53 & 1.15 & 0.75 & 0.75 & 0.92 \\
\hline 1741 & 0.91 & 1.86 & 1.10 & 0.38 & 1.25 & 0.75 & 0.83 & 0.83 \\
\hline 1742 & 1.37 & 1.12 & 1.32 & 0.53 & 1.04 & 0.62 & 0.69 & 1.11 \\
\hline 1743 & 1.60 & 1.86 & 1.32 & 0.66 & 1.46 & 0.63 & 0.43 & 1.39 \\
\hline 1744 & 1.65 & 1.42 & 1.72 & 0.53 & 1.04 & 0.93 & 1.13 & 1.39 \\
\hline 1745 & 1.15 & 1.58 & 1.78 & 0.59 & 1.04 & 1.37 & 1.41 & 1.39 \\
\hline 1746 & 1.10 & 2.23 & 1.70 & 0.71 & 1.43 & 1.89 & 1.13 & 1.39 \\
\hline 1747 & 1.30 & 1.68 & 1.48 & 0.89 & 1.69 & 1.37 & 1.85 & 1.67 \\
\hline 1748 & 1.34 & 2.33 & 2.07 & 0.71 & 2.50 & 0.84 & 1.88 & 2.08 \\
\hline 1749 & 1.10 & 3.35 & 2.63 & 1.01 & 1.67 & 0.74 & 0.50 & 1.67 \\
\hline 1750 & 1.40 & 2.79 & 1.17 & 0.71 & 1.46 & 1.05 & 0.50 & 1.11 \\
\hline 1751 & 1.50 & 2.93 & 1.64 & 0.67 & 1.15 & 0.63 & 0.75 & 1.67 \\
\hline 1752 & 2.00 & 2.65 & 1.32 & 0.59 & 1.04 & 0.84 & 0.98 & 2.08 \\
\hline 1753 & 2.00 & 3.20 & 1.64 & 0.71 & 1.25 & 0.63 & 0.94 & 2.78 \\
\hline 1754 & 1.80 & 3.00 & 1.56 & 0.83 & 1.37 & 0.78 & 0.81 & 2.50 \\
\hline 1755 & 1.53 & 2.72 & 1.64 & 0.28 & 1.46 & 0.58 & 0.59 & 2.50 \\
\hline 1756 & 1.60 & 3.36 & 1.23 & 0.29 & 1.01 & 1.05 & 1.50 & 2.36 \\
\hline 1757 & 2.90 & 3.86 & 1.86 & 0.83 & 1.84 & 1.05 & 1.19 & 3.06 \\
\hline 1758 & 6.12 & 6.12 & 2.63 & 1.19 & 2.92 & 2.64 & 2.64 & 6.39 \\
\hline 1759 & 7.99 & 8.94 & 5.14 & 1.54 & 5.07 & 3.44 & 3.45 & 8.89 \\
\hline 1760 & 5.99 & 8.14 & 3.62 & 0.71 & 3.80 & 2.53 & 1.88 & 6.67 \\
\hline
\end{tabular}


Table A4.1: Index number for prices of goods, 1720-1724=1 (continued)

\begin{tabular}{|c|c|c|c|c|c|c|c|c|}
\hline & \multicolumn{5}{|c|}{ BURNING } & \multicolumn{3}{|c|}{ OLIVE } \\
\hline & HAY & PEAS & BRAN & OIL & FLOUR & NAILS & OIL & CODFISH \\
\hline 1688 & 1.09 & 0.85 & 0.66 & 0.70 & 1.05 & 0.48 & 0.40 & 0.65 \\
\hline 1689 & 1.09 & 1.07 & 0.72 & 0.70 & 1.33 & 0.48 & 0.54 & 0.73 \\
\hline 1690 & 1.35 & 1.92 & 1.15 & 0.96 & 2.51 & 0.67 & 0.89 & 1.13 \\
\hline 1691 & 1.20 & 1.92 & 1.18 & 1.04 & 3.34 & 0.61 & 0.67 & 1.09 \\
\hline 1692 & 1.30 & 2.19 & 1.15 & 1.44 & 1.88 & 0.54 & 0.72 & 1.05 \\
\hline 1693 & 1.38 & 2.78 & 1.31 & 1.67 & 3.14 & 0.61 & 0.89 & 1.47 \\
\hline 1694 & 1.31 & 1.10 & 0.79 & 1.81 & 1.25 & 0.61 & 0.85 & 1.09 \\
\hline 1695 & 1.42 & 1.07 & 0.66 & 1.67 & 1.05 & 0.67 & 0.81 & 1.09 \\
\hline 1696 & 2.91 & 1.28 & 0.72 & 1.67 & 1.72 & 0.73 & 0.81 & 0.73 \\
\hline 1697 & 1.71 & 1.28 & 0.98 & 1.44 & 2.93 & 0.61 & 0.89 & 0.82 \\
\hline 1698 & 1.82 & 1.39 & 1.05 & 1.44 & 1.30 & 0.56 & 0.89 & 1.06 \\
\hline 1699 & 1.71 & 1.49 & 0.98 & 1.08 & 2.10 & 0.54 & 0.81 & 0.64 \\
\hline 1700 & 1.55 & 2.56 & 1.18 & 1.32 & 2.75 & 0.48 & 0.69 & 0.64 \\
\hline 1701 & 1.68 & 2.56 & 1.05 & 1.20 & 2.61 & 0.61 & 0.89 & 0.73 \\
\hline 1702 & 1.70 & 1.07 & 1.07 & 1.44 & 1.18 & 0.51 & 0.95 & 0.91 \\
\hline 1703 & 1.51 & 1.07 & 0.89 & 1.56 & 1.08 & 0.73 & 0.92 & 0.91 \\
\hline 1704 & 1.22 & 0.85 & 0.79 & 1.20 & 1.05 & 0.58 & 0.72 & 0.73 \\
\hline 1705 & 1.60 & 0.64 & 0.66 & 1.08 & 1.05 & 0.36 & 0.54 & 0.92 \\
\hline 1706 & 1.53 & 0.64 & 0.68 & 0.96 & 0.89 & 0.73 & 0.69 & 0.91 \\
\hline 1707 & 1.27 & 0.85 & 0.56 & 0.96 & 0.89 & 0.73 & 0.78 & 1.00 \\
\hline 1708 & 1.24 & 1.28 & 0.79 & 1.08 & 1.36 & 0.85 & 0.89 & 1.09 \\
\hline 1709 & 0.87 & 1.17 & 0.66 & 1.44 & 1.23 & 0.97 & 0.89 & 1.13 \\
\hline 1710 & 1.86 & 1.47 & 0.72 & 0.96 & 1.36 & 0.97 & 1.12 & 1.09 \\
\hline 1711 & 2.55 & 1.39 & 0.79 & 1.08 & 1.36 & 0.97 & 1.57 & 1.09 \\
\hline 1712 & 2.91 & 1.25 & 0.72 & 1.20 & 1.15 & 0.73 & 0.89 & 0.75 \\
\hline 1713 & 1.53 & 1.28 & 0.92 & 1.20 & 1.36 & 1.21 & 1.12 & 1.18 \\
\hline 1714 & 2.18 & 2.03 & 1.03 & 2.15 & 2.30 & 0.97 & 1.34 & 1.27 \\
\hline 1715 & 4.85 & 2.35 & 1.80 & 2.87 & 3.34 & 1.45 & 2.68 & 3.27 \\
\hline 1716 & 2.55 & 3.13 & 2.62 & 2.87 & 3.21 & 1.45 & 3.36 & 3.82 \\
\hline 1717 & 9.10 & 4.27 & 3.93 & 3.83 & 3.14 & 1.45 & 3.13 & 3.27 \\
\hline 1718 & 5.46 & 4.27 & 4.59 & 3.59 & 3.55 & 2.18 & 4.03 & 3.64 \\
\hline 1719 & 6.32 & 3.42 & 3.93 & 3.83 & 2.93 & 2.18 & 4.03 & 3.27 \\
\hline 1720 & 0.87 & 1.00 & 1.31 & 1.05 & 0.89 & 1.21 & 0.97 & 1.00 \\
\hline 1721 & 1.24 & 0.85 & 0.98 & 0.96 & 0.84 & 1.09 & 0.89 & 0.91 \\
\hline 1722 & 0.92 & 0.96 & 0.98 & 0.96 & 0.84 & 0.97 & 1.23 & 1.00 \\
\hline 1723 & 0.87 & 1.07 & 0.74 & 1.08 & 1.15 & 0.94 & 1.01 & 1.00 \\
\hline 1724 & 1.09 & 1.12 & 0.98 & 0.96 & 1.29 & 0.79 & 0.89 & 1.09 \\
\hline 1725 & 1.09 & 1.17 & 0.89 & 0.96 & 1.12 & 0.97 & 0.89 & 1.18 \\
\hline 1726 & 0.87 & 0.85 & 0.95 & 0.96 & 0.84 & 0.74 & 1.34 & 1.27 \\
\hline
\end{tabular}


Table A4.1: Index number for prices of goods, 1720-1724=1 (continued)

\begin{tabular}{|c|c|c|c|c|c|c|c|c|}
\hline & \multicolumn{8}{|c|}{ OLIVE } \\
\hline & HAY & PEAS & BRAN & OIL & FLOUR & NAILS & OIL & CODFISH \\
\hline 1727 & 1.09 & 0.96 & 0.92 & 0.84 & 0.80 & 0.29 & 0.58 & 1.09 \\
\hline 1728 & 1.09 & 0.82 & 0.70 & 0.96 & 1.01 & 0.44 & 0.58 & 0.91 \\
\hline 1729 & 1.09 & 1.28 & 0.88 & 1.08 & 0.99 & 0.49 & 0.54 & 0.73 \\
\hline 1730 & 1.52 & 1.28 & 1.97 & 1.44 & 1.25 & 0.73 & 0.89 & 1.25 \\
\hline 1731 & 1.46 & 1.17 & 1.31 & 1.44 & 1.05 & 0.53 & 0.94 & 1.09 \\
\hline 1732 & 1.82 & 1.10 & 1.97 & 0.80 & 0.94 & 1.09 & 0.51 & 1.09 \\
\hline 1733 & 1.52 & 1.28 & 2.02 & 1.10 & 1.05 & 0.58 & 0.63 & 1.09 \\
\hline 1734 & 0.87 & 1.23 & 1.97 & 1.09 & 0.89 & 0.73 & 0.67 & 1.09 \\
\hline 1735 & 1.52 & 0.91 & 1.15 & 0.96 & 0.84 & 0.73 & 0.67 & 1.09 \\
\hline 1736 & 1.31 & 1.07 & 1.31 & 0.96 & 0.89 & 1.45 & 0.63 & 0.97 \\
\hline 1737 & 2.18 & 1.28 & 1.64 & 1.20 & 1.25 & 0.53 & 0.67 & 0.95 \\
\hline 1738 & 1.68 & 1.28 & 1.64 & 0.90 & 1.05 & 1.00 & 0.86 & 0.91 \\
\hline 1739 & 1.09 & 1.07 & 1.97 & 0.96 & 0.94 & 1.33 & 0.81 & 0.91 \\
\hline 1740 & 1.17 & 0.75 & 0.98 & 1.00 & 0.84 & 0.53 & 0.89 & 0.91 \\
\hline 1741 & 1.17 & 0.88 & 1.56 & 0.72 & 0.86 & 0.73 & 0.89 & 0.91 \\
\hline 1742 & 1.46 & 1.28 & 2.35 & 0.96 & 1.28 & 0.48 & 1.57 & 1.09 \\
\hline 1743 & 1.74 & 1.71 & 2.74 & 1.05 & 1.67 & 0.61 & 1.69 & 1.00 \\
\hline 1744 & 1.35 & 1.65 & 5.41 & 1.44 & 1.62 & 0.79 & 1.74 & 1.09 \\
\hline 1745 & 1.38 & 1.07 & 3.61 & 0.68 & 1.31 & 1.65 & 0.92 & 1.66 \\
\hline 1746 & 1.95 & 1.31 & 2.08 & 0.54 & 1.10 & 1.45 & 1.57 & 1.58 \\
\hline 1747 & 2.04 & 1.49 & 1.31 & 0.70 & 1.46 & 2.91 & 1.12 & 2.18 \\
\hline 1748 & 3.28 & 2.03 & 1.64 & 0.75 & 1.25 & 2.91 & 0.89 & 2.00 \\
\hline 1749 & 2.91 & 1.49 & 1.66 & 0.96 & 1.36 & 0.97 & 0.67 & 1.14 \\
\hline 1750 & 2.79 & 1.71 & 2.56 & 1.67 & 0.89 & 0.50 & 0.55 & 1.09 \\
\hline 1751 & 2.18 & 1.72 & 2.74 & 1.44 & 1.46 & 0.61 & 0.67 & 1.00 \\
\hline 1752 & 2.62 & 2.43 & 3.66 & 1.20 & 1.46 & 0.53 & 0.67 & 1.66 \\
\hline 1753 & 3.50 & 2.99 & 3.15 & 0.96 & 0.89 & 0.93 & 0.72 & 1.45 \\
\hline 1754 & 1.97 & 1.92 & 3.93 & 0.80 & 1.16 & 0.64 & 0.81 & 1.09 \\
\hline 1755 & 3.64 & 2.13 & 5.25 & 0.55 & 1.82 & 0.51 & 0.57 & 1.48 \\
\hline 1756 & 2.18 & 2.56 & 6.56 & 0.80 & 2.51 & 0.19 & 1.34 & 1.64 \\
\hline 1757 & 1.82 & 2.74 & 5.25 & 1.20 & 4.18 & 0.34 & 1.12 & 1.82 \\
\hline 1758 & 3.03 & 2.99 & 16.89 & 1.53 & 5.64 & 0.97 & 1.57 & 2.18 \\
\hline 1759 & 5.24 & 8.97 & 22.04 & 2.84 & 8.36 & 0.48 & 2.68 & 3.04 \\
\hline 1760 & 4.77 & 17.08 & 16.53 & 2.13 & 7.11 & 0.70 & 2.25 & 3.27 \\
\hline
\end{tabular}


Table A4.1: Index number for prices of goods, 1720-1724=1 (continued)

\begin{tabular}{|c|c|c|c|c|c|c|c|c|}
\hline & BUTTER & LARD & SOCKS & EGGS & EELS & BEEF & CANDLES & SALT \\
\hline 1688 & 1.11 & 1.19 & 0.91 & 0.95 & 0.59 & 1.37 & 0.55 & 0.79 \\
\hline 1689 & 1.11 & 1.19 & 1.03 & 0.95 & 0.70 & 1.37 & 0.55 & 0.84 \\
\hline 1690 & 1.11 & 1.39 & 1.03 & 0.87 & 1.08 & 1.20 & 0.69 & 0.93 \\
\hline 1691 & 1.48 & 1.98 & 1.03 & 1.43 & 1.23 & 1.37 & 0.80 & 1.50 \\
\hline 1692 & 1.48 & 1.78 & 1.03 & 1.27 & 1.17 & 1.89 & 0.69 & 1.50 \\
\hline 1693 & 1.63 & 1.78 & 1.10 & 0.95 & 0.92 & 1.72 & 0.70 & 1.40 \\
\hline 1694 & 1.48 & 1.58 & 1.16 & 1.27 & 0.72 & 1.55 & 0.87 & 1.31 \\
\hline 1695 & 1.63 & 1.58 & 1.10 & 0.95 & 1.14 & 1.55 & 0.80 & 1.12 \\
\hline 1696 & 1.78 & 1.39 & 1.25 & 1.29 & 0.96 & 1.37 & 0.92 & 1.31 \\
\hline 1697 & 1.41 & 1.39 & 1.16 & 0.95 & 1.07 & 1.72 & 0.87 & 1.87 \\
\hline 1698 & 1.33 & 1.65 & 1.16 & 1.27 & 1.02 & 1.20 & 0.80 & 1.59 \\
\hline 1699 & 1.48 & 1.58 & 1.16 & 1.38 & 1.10 & 1.72 & 0.71 & 1.40 \\
\hline 1700 & 1.33 & 1.98 & 0.78 & 0.93 & 1.11 & 1.20 & 0.55 & 0.84 \\
\hline 1701 & 1.48 & 1.58 & 1.29 & 0.95 & 1.01 & 1.55 & 0.80 & 1.03 \\
\hline 1702 & 1.18 & 1.58 & 1.00 & 0.95 & 1.06 & 1.55 & 0.69 & 1.03 \\
\hline 1703 & 1.04 & 1.34 & 0.91 & 0.95 & 0.79 & 1.37 & 0.74 & 0.89 \\
\hline 1704 & 0.96 & 1.19 & 0.97 & 0.95 & 0.89 & 1.55 & 0.74 & 1.43 \\
\hline 1705 & 0.74 & 1.19 & 0.89 & 0.95 & 0.92 & 1.03 & 0.69 & 1.25 \\
\hline 1706 & 1.18 & 0.99 & 0.97 & 0.79 & 0.80 & 0.69 & 0.69 & 1.59 \\
\hline 1707 & 1.18 & 1.19 & 1.49 & 0.87 & 0.89 & 0.86 & 0.55 & 1.68 \\
\hline 1708 & 1.13 & 0.99 & 0.65 & 0.79 & 0.89 & 0.69 & 0.57 & 1.78 \\
\hline 1709 & 1.04 & 1.19 & 1.03 & 1.03 & 1.05 & 0.86 & 0.69 & 1.87 \\
\hline 1710 & 1.33 & 1.58 & 1.55 & 1.15 & 0.96 & 1.03 & 0.69 & 1.68 \\
\hline 1711 & 1.33 & 1.58 & 1.23 & 1.43 & 1.04 & 1.20 & 1.40 & 1.68 \\
\hline 1712 & 1.97 & 1.58 & 1.57 & 1.59 & 1.04 & 1.46 & 1.00 & 2.66 \\
\hline 1713 & 1.92 & 1.58 & 1.77 & 1.82 & 1.33 & 1.72 & 0.80 & 1.54 \\
\hline 1714 & 2.59 & 2.77 & 1.68 & 1.27 & 1.48 & 1.55 & 1.38 & 2.80 \\
\hline 1715 & 2.96 & 2.64 & 2.59 & 1.98 & 2.96 & 2.45 & 1.38 & 5.23 \\
\hline 1716 & 3.33 & 3.96 & 2.84 & 3.17 & 4.64 & 2.40 & 1.38 & 5.61 \\
\hline 1717 & 3.70 & 4.59 & 3.19 & 3.17 & 4.44 & 3.43 & 2.41 & 3.93 \\
\hline 1718 & 4.44 & 4.95 & 2.84 & 3.17 & 3.26 & 2.06 & 0.92 & 2.62 \\
\hline 1719 & 4.74 & 4.42 & 2.59 & 3.91 & 2.16 & 3.43 & 1.84 & 4.05 \\
\hline 1720 & 1.11 & 0.99 & 1.16 & 1.35 & 0.89 & 1.37 & 0.92 & 0.84 \\
\hline 1721 & 1.14 & 1.14 & 0.97 & 0.71 & 1.03 & 0.86 & 1.67 & 0.84 \\
\hline 1722 & 1.04 & 1.06 & 0.91 & 0.96 & 1.19 & 0.86 & 0.75 & 1.07 \\
\hline 1723 & 0.74 & 0.99 & 0.99 & 0.95 & 1.01 & 0.88 & 0.82 & 0.93 \\
\hline 1724 & 0.98 & 0.83 & 0.97 & 1.03 & 0.89 & 1.03 & 0.84 & 1.31 \\
\hline 1725 & 1.04 & 1.02 & 0.97 & 0.79 & 0.59 & 1.37 & 0.82 & 1.21 \\
\hline 1726 & 0.89 & 1.19 & 0.97 & 0.95 & 0.89 & 1.72 & 0.50 & 1.21 \\
\hline
\end{tabular}


Table A4.1: Index number for prices of goods, 1720-1724=1 (continued)

\begin{tabular}{|c|c|c|c|c|c|c|c|c|}
\hline & BUTTER & LARD & SOCKS & EGGS & EELS & BEEF & CANDLES & SALT \\
\hline 1727 & 0.99 & 1.39 & 1.00 & 0.87 & 0.52 & 0.86 & 0.79 & 0.70 \\
\hline 1728 & 0.96 & 0.99 & 0.70 & 0.71 & 0.74 & 0.94 & 0.59 & 0.75 \\
\hline 1729 & 0.89 & 0.79 & 0.71 & 0.79 & 1.33 & 1.03 & 0.69 & 0.70 \\
\hline 1730 & 1.18 & 1.39 & 0.71 & 0.71 & 1.30 & 1.09 & 0.50 & 0.89 \\
\hline 1731 & 1.18 & 1.09 & 0.91 & 0.85 & 1.04 & 0.86 & 0.84 & 0.90 \\
\hline 1732 & 1.17 & 1.19 & 0.97 & 0.99 & 1.07 & 0.86 & 0.71 & 0.75 \\
\hline 1733 & 1.20 & 1.39 & 0.99 & 0.87 & 1.33 & 1.03 & 0.56 & 1.09 \\
\hline 1734 & 1.14 & 1.04 & 0.87 & 1.08 & 1.11 & 1.07 & 0.67 & 1.54 \\
\hline 1735 & 1.04 & 0.69 & 0.78 & 1.08 & 0.79 & 1.03 & 0.56 & 0.84 \\
\hline 1736 & 1.06 & 0.74 & 0.78 & 0.79 & 1.56 & 0.86 & 0.59 & 0.75 \\
\hline 1737 & 1.18 & 0.99 & 0.91 & 0.87 & 1.56 & 1.20 & 0.61 & 0.84 \\
\hline 1738 & 1.38 & 1.09 & 0.91 & 0.84 & 1.13 & 1.03 & 0.63 & 1.31 \\
\hline 1739 & 1.18 & 1.19 & 0.78 & 1.11 & 1.36 & 1.03 & 0.67 & 1.12 \\
\hline 1740 & 1.17 & 0.74 & 0.91 & 0.87 & 1.03 & 0.86 & 0.50 & 0.36 \\
\hline 1741 & 1.23 & 0.94 & 0.86 & 1.03 & 1.11 & 1.12 & 0.54 & 0.39 \\
\hline 1742 & 1.11 & 1.02 & 1.30 & 1.03 & 2.12 & 0.86 & 0.67 & 0.75 \\
\hline 1743 & 1.26 & 2.05 & 1.51 & 0.95 & 1.78 & 1.03 & 0.71 & 0.56 \\
\hline 1744 & 1.31 & 1.56 & 1.56 & 1.00 & 1.78 & 1.03 & 0.75 & 0.70 \\
\hline 1745 & 1.26 & 1.50 & 1.09 & 1.00 & 1.78 & 1.72 & 0.75 & 2.90 \\
\hline 1746 & 1.33 & 1.88 & 1.19 & 1.30 & 2.37 & 1.12 & 0.84 & 3.36 \\
\hline 1747 & 1.78 & 1.39 & 1.41 & 1.39 & 2.37 & 1.20 & 1.05 & 3.93 \\
\hline 1748 & 1.83 & 1.35 & 1.45 & 1.64 & 2.37 & 1.55 & 1.25 & 4.49 \\
\hline 1749 & 1.85 & 1.41 & 1.19 & 1.45 & 2.96 & 1.20 & 1.13 & 0.84 \\
\hline 1750 & 1.72 & 1.29 & 0.78 & 1.38 & 2.37 & 0.94 & 0.92 & 1.12 \\
\hline 1751 & 1.76 & 2.18 & 0.58 & 1.33 & 2.22 & 1.12 & 0.84 & 1.15 \\
\hline 1752 & 1.48 & 1.98 & 0.91 & 1.27 & 3.56 & 1.37 & 0.84 & 0.84 \\
\hline 1753 & 1.55 & 2.97 & 0.52 & 1.65 & 2.22 & 1.89 & 0.84 & 1.22 \\
\hline 1754 & 1.63 & 2.08 & 0.71 & 2.04 & 2.90 & 1.78 & 0.84 & 1.10 \\
\hline 1755 & 1.83 & 2.18 & 0.31 & 1.74 & 2.73 & 1.89 & 1.34 & 1.68 \\
\hline 1756 & 1.78 & 2.03 & 0.32 & 1.95 & 2.96 & 2.32 & 1.34 & 2.24 \\
\hline 1757 & 2.00 & 3.10 & 0.58 & 2.38 & 3.72 & 2.69 & 1.67 & 2.62 \\
\hline 1758 & 3.95 & 4.95 & 1.23 & 3.57 & 10.13 & 4.29 & 1.67 & 2.73 \\
\hline 1759 & 4.69 & 3.96 & 1.60 & 6.34 & 13.21 & 7.69 & 1.67 & 14.95 \\
\hline 1760 & 4.65 & 5.28 & 1.20 & 6.87 & 11.11 & 6.87 & 1.67 & 5.44 \\
\hline
\end{tabular}


Table A4.1: Index number for prices of goods, 1720-1724=1 (continued)

\begin{tabular}{|c|c|c|}
\hline & SOAP & CLOTH \\
\hline 1688 & 0.76 & 0.66 \\
\hline 1689 & 0.85 & 0.86 \\
\hline 1690 & 0.76 & 0.78 \\
\hline 1691 & 0.85 & 0.71 \\
\hline 1692 & 1.07 & 0.73 \\
\hline 1693 & 0.88 & 0.90 \\
\hline 1694 & 1.26 & 0.76 \\
\hline 1695 & 1.07 & 0.92 \\
\hline 1696 & 1.13 & 0.76 \\
\hline 1697 & 1.25 & 0.78 \\
\hline 1698 & 1.20 & 0.79 \\
\hline 1699 & 0.85 & 0.81 \\
\hline 1700 & 0.66 & 0.72 \\
\hline 1701 & 0.94 & 0.89 \\
\hline 1702 & 0.88 & 0.84 \\
\hline 1703 & 0.42 & 1.02 \\
\hline 1704 & 0.41 & 1.05 \\
\hline 1705 & 0.94 & 0.87 \\
\hline 1706 & 0.95 & 0.92 \\
\hline 1707 & 1.57 & 1.02 \\
\hline 1708 & 1.48 & 1.11 \\
\hline 1709 & 0.92 & 0.83 \\
\hline 1710 & 0.94 & 0.88 \\
\hline 1711 & 1.10 & 0.78 \\
\hline 1712 & 1.89 & 2.09 \\
\hline 1713 & 2.20 & 1.11 \\
\hline 1714 & 2.73 & 1.32 \\
\hline 1715 & 4.29 & 1.66 \\
\hline 1716 & 5.03 & 2.46 \\
\hline 1717 & 3.93 & 2.34 \\
\hline 1718 & 4.29 & 1.66 \\
\hline 1719 & 3.78 & 3.18 \\
\hline 1720 & 0.57 & 1.23 \\
\hline 1721 & 1.26 & 0.82 \\
\hline 1722 & 1.15 & 1.04 \\
\hline 1723 & 0.94 & 0.86 \\
\hline 1724 & 1.08 & 1.05 \\
\hline 1725 & 1.04 & 1.02 \\
\hline 1726 & 0.65 & 0.57 \\
\hline
\end{tabular}


Table A4.1: Index number for prices of goods, 1720-1724=1 (continued)

\begin{tabular}{|c|c|c|}
\hline & SOAP & CLOTH \\
\hline 1727 & 1.26 & 0.87 \\
\hline 1728 & 0.63 & 0.78 \\
\hline 1729 & 0.69 & 0.82 \\
\hline 1730 & 0.63 & 0.90 \\
\hline 1731 & 0.50 & 1.02 \\
\hline 1732 & 0.63 & 0.86 \\
\hline 1733 & 0.69 & 1.00 \\
\hline 1734 & 0.76 & 1.08 \\
\hline 1735 & 1.13 & 0.89 \\
\hline 1736 & 0.42 & 0.56 \\
\hline 1737 & 0.42 & 0.78 \\
\hline 1738 & 0.50 & 0.79 \\
\hline 1739 & 0.40 & 0.68 \\
\hline 1740 & 0.31 & 0.49 \\
\hline 1741 & 0.33 & 0.53 \\
\hline 1742 & 0.50 & 0.79 \\
\hline 1743 & 0.58 & 0.92 \\
\hline 1744 & 0.60 & 0.95 \\
\hline 1745 & 1.14 & 0.65 \\
\hline 1746 & 1.42 & 0.82 \\
\hline 1747 & 1.13 & 1.11 \\
\hline 1748 & 1.20 & 1.26 \\
\hline 1749 & 1.08 & 0.82 \\
\hline 1750 & 0.45 & 0.74 \\
\hline 1751 & 0.57 & 1.34 \\
\hline 1752 & 0.65 & 0.83 \\
\hline 1753 & 0.57 & 0.86 \\
\hline 1754 & 0.58 & 1.29 \\
\hline 1755 & 0.37 & 0.33 \\
\hline 1756 & 0.38 & 0.35 \\
\hline 1757 & 0.57 & 0.63 \\
\hline 1758 & 1.26 & 0.90 \\
\hline 1759 & 1.87 & 1.85 \\
\hline 1760 & 2.52 & 2.22 \\
\hline
\end{tabular}


Table A4.2: Wages for skilled and unskilled workers (in livres per day)

\begin{tabular}{|c|c|c|}
\hline & Unskilled & Carpenters \\
\hline 1688 & 1.33 & 2.83 \\
\hline 1689 & 1.33 & 2.83 \\
\hline 1690 & 1.00 & 2.83 \\
\hline 1691 & 1.42 & 2.00 \\
\hline 1692 & 1.40 & 2.38 \\
\hline 1693 & 1.55 & 2.75 \\
\hline 1694 & 1.33 & 2.25 \\
\hline 1695 & 1.38 & 2.60 \\
\hline 1696 & 1.44 & 2.70 \\
\hline 1697 & 1.71 & 2.88 \\
\hline 1698 & 1.44 & 2.50 \\
\hline 1699 & 1.45 & 2.55 \\
\hline 1700 & 1.68 & 2.88 \\
\hline 1701 & 1.63 & 2.50 \\
\hline 1702 & 1.50 & 2.81 \\
\hline 1703 & 1.50 & 2.00 \\
\hline 1704 & 1.33 & 2.42 \\
\hline 1705 & 1.50 & 2.38 \\
\hline 1706 & 1.40 & 2.50 \\
\hline 1707 & 1.35 & 2.17 \\
\hline 1708 & 1.50 & 1.92 \\
\hline 1709 & 1.21 & 2.28 \\
\hline 1710 & 1.00 & 2.75 \\
\hline 1711 & 1.00 & 2.77 \\
\hline 1712 & 1.27 & 2.58 \\
\hline 1713 & 1.56 & 2.63 \\
\hline 1714 & 1.88 & 3.23 \\
\hline 1715 & 1.61 & 4.32 \\
\hline 1716 & 2.50 & 5.72 \\
\hline 1717 & 2.88 & 7.25 \\
\hline 1718 & 3.14 & 8.80 \\
\hline 1719 & 2.59 & 8.60 \\
\hline 1720 & 1.30 & 3.00 \\
\hline 1721 & 1.38 & 3.00 \\
\hline 1722 & 1.67 & 3.00 \\
\hline 1723 & 1.61 & 3.00 \\
\hline 1724 & 1.38 & 2.50 \\
\hline 1725 & 1.49 & 2.11 \\
\hline 1726 & 1.50 & 2.00 \\
\hline
\end{tabular}


Table A4.2: Wages for skilled and unskilled workers (in livres per day) (continued)

\begin{tabular}{ccc} 
& Unskilled & Skilled \\
\hline 1727 & 1.00 & 2.10 \\
1728 & 0.65 & 2.34 \\
1729 & 0.65 & 2.62 \\
1730 & 1.00 & 2.86 \\
1731 & 1.50 & 3.00 \\
1732 & 1.42 & 3.00 \\
1733 & 1.25 & 3.00 \\
1734 & 1.40 & 2.98 \\
1735 & 1.08 & 2.93 \\
1736 & 1.28 & 2.84 \\
1737 & 2.00 & 2.74 \\
1738 & 1.25 & 2.63 \\
1739 & 1.25 & 2.50 \\
1740 & 1.55 & 2.36 \\
1741 & 1.21 & 2.21 \\
1742 & 1.06 & 2.00 \\
1743 & 1.13 & 1.76 \\
1744 & 1.00 & 1.58 \\
1745 & 1.17 & 1.62 \\
1746 & 1.25 & 2.00 \\
1747 & 1.81 & 2.50 \\
1748 & 1.63 & 2.38 \\
1749 & 1.75 & 3.12 \\
1750 & 1.91 & 3.15 \\
1751 & 1.83 & 3.00 \\
1752 & 1.75 & 3.72 \\
1753 & 2.19 & 5.00 \\
1754 & 1.63 & 5.66 \\
1755 & 2.00 & 5.67 \\
1756 & 2.26 & 5.35 \\
1757 & 2.17 & 5.02 \\
1758 & 1.99 & 5.00 \\
1759 & 2.00 & 5.60 \\
1760 & 2.46 & 7.14 \\
\hline & &
\end{tabular}




\section{BIBLIOGRAPHY}

\section{PRIMARY SOURCES:}

Archives du Séminaire de Québec (ASQ)

Livre C4-Grand Livre

Livre C5-Grand Livre

Livre C6-Grand Livre Auxiliaire

Livre C7-Grand Livre

Livre C8-Grand Livre

Livre C9-Grand Livre

Livre C11-Dépenses : Économe

Livre C12-Brouillard recettes-dépenses

Livre C13-Brouillard recettes-dépenses

Livre C14-Brouillard recettes-dépenses

Livre C15-Brouillard recettes-dépenses

Livre C16-Brouillard dépenses

Livre C17-Brouillard recettes

Livre C18-Brouillard auxiliaire recettes-dépenses

Livre C19-Brouillard dépenses

Livre C20-Brouillard recettes-dépenses

Livre C21-Brouillard recettes-dépenses

Livre C22-Brouillard recettes

Livre C23-Brouillard dépenses

Livre C24-Brouillard auxiliaire recettes-dépenses

Répertoire des titres, Saint-Ferréol

SMES/1/15d-L'abbé Jean-Frs Buisson de St-Côme demande au Conseil Souverain l'enregistrement de la concession et du Brevet de confirmation de la concession de l'île Jésus au Séminaire de Québec.

SMES/1/15e-Brevet de confirmation de la concession de l'île Jésus au Séminaire de Québec.

Archives des Ursulines de Québec (AUQ)

1/N6, 2,1.1-Livres des Recettes et Dépenses, 1716-1746

1/N6, 2,1.2-Livres des Recettes et Dépenses, 1747-1781

British Library

Haldimand Collection, Additional Manuscripts 21681-21682

Library and Archives Canada

Série C11A-Correspondance générale; Canada (R11577-4-2-F)

Microfilm F-78

Microfilm F-79

Microfilm F-80 
Microfilm F-82

Microfilm F-83

Microfilm F-84

Microfilm F-116

Microfilm C-2407

\section{SECONDARY SOURCES:}

Abramitzky, Ran and Fabio Braggion. 2006. "Migration and Human: Self-Selection of Indentured Servants to the Americas", Journal of Economic History, Vol.66, no.4, pp.882-905.

Acemoglu, Daron, Simon Johnson and James Robinson. 1999. "The Colonial Origins of Comparative Development: An Empirical Investigation", American Economic Review, Vol.91, no.5, pp.1369-1401.

Acemoglu, Daron, Simon Johnson and James Robinson. 2005. "Institutions as a fundamental cause of long-run growth" in eds. Philippe Aghion and Steven Durlauf, Handbook of Economic Growth, Vol 1A. New York, NY: North Holland, pp. 386-464.

Albouy, David. 2012. "The Colonial Origins of Comparative Development: An Empirical Investigation: Comment” American Economic Review, Vol.102, no.6, pp.3059-3076.

Allen, Robert. 2000. "Economic structure and agricultural productivity in Europe, 1300-1800", European Review of Economic History, Vol.4, no.1, pp.1-25.

Allen, Robert. 2001. "The great divergence in European wages and prices from the Middle Ages to the First World War" Explorations in economic history, Vol.38, no.4, pp.411-447.

Allen, Robert. 2009. “How Prosperous were the Romans? Evidence from Diocletian's Price Edict (AD 301)" in eds. Alan Bowman and Andrew Wilson, Quantifying the Roman Economy: Methods and Problems. Oxford: Oxford University Press, pp.327-345.

Allen, Robert. 2009. The British Industrial Revolution in Global Perspective. Cambridge: Cambridge University.

Allen, Robert. 2013. Poverty Lines in History, Theory, and Current International Practice. Discussion Paper Series, Department of Economics, Oxford University.

Allen, Robert, Jean-Pascal Bassino, Debin Ma, Christine Moll-Murata and Jan Luiten Van Zanden. 2011. "Wages, prices, and living standards in China, 1738-1925: in comparison with Europe, Japan and India", The Economic History Review, Vol.64, no.S1, pp.8-38. 
Allen, Robert, Tommy Murphy and Eric Schneider. 2012. "The Colonial Origins of the Divergence in the Americas: A Labor Market Approach", Journal of Economic History, Vol. 72, no. 4, pp.863-94.

Allen, Robert, Tommy Murphy and Eric Schneider. 2015. "Una de cal y otra de arena: building comparable real wages in a global perspective." Revista de Historia Económica/Journal of Iberian and Latin American Economic History, Vol.33, no.1, p.61-75.

Altman, Morris. 1983. "Seigniorial Tenure in New France, 1688-1739: An Essay on Income Distribution and Retarded Economic Development". Historical Reflections / Réflexions historiques, Vol.10, No.3, pp.335-375.

Altman, Morris. 1987. "Note on the Economic Burden of the Seigneurial System in New France, 1688-1730”. Historical Reflections / Réflexions historiques, Vol.14, No.1, pp.135-142.

Altman, Morris. 1988. "Economic Growth, Economic Structure and Real Gross Domestic Product in Early Canada, 1695-1739" William and Mary Quarterly, Vol.45, p.684-711.

Altman, Morris. 1988. "Economic development with high wages: an historical perspective", Explorations in Economic History, Vol.25, no.2, pp.198-224.

Altman, Morris. 1998. "Land Tenure, Ethnicity, and the Condition of Agricultural Income and Productivity in Mid-Nineteenth-Century Quebec", Agricultural History, Vol.72, No.4, pp. 708-762.

Altman, Morris. 2003. "Staple theory and export-led growth: constructing differential growth", Australian Economic History Review, Vol.43, no.3, pp.230-255.

Álvarez-Nogal, Carlos, and Leandro Prados De La Escosura. 2013. "The rise and fall of Spain (1270-1850)", Economic History Review, Vol.66, No.1, pp.1-37.

Anderson, Terry L. 1979. "Economic Growth in Colonial New England: Statistical Renaissance", Journal of Economic History, Vol.39, no.1, p.243-257.

Armstrong, Robert. 1984. Structure and Change: An Economic History of Quebec. Toronto: Gage Publishing.

Armstrong, Robert. 1984. "The Efficiency of Quebec Farmers in 1851", Histoire sociale / Social History, Vol.17, no.33, pp.149-163.

Arroyo Abad, Leticia, Elwyn Davies and Jan Luiten van Zanden. 2012. "Between conquest and independence: real wages and demographic change in Spanish America, 1530-1820", Explorations in Economic History, Vol.49, no.2, pp.149-166. 
Arroyo Abad, Leticia and Jan Luiten Van Zanden. 2015. "Optimistic but Flawed? A reply" Revista de Historia Económica/Journal of Iberian and Latin American Economic History, Vol.33, no. 1, pp.77-82

Aubry, François. 1970. Indicators of Economic Growth for Lower Canada, 1760-1850. Ottawa: MA Thesis, Department of History, University of Ottawa.

Audet, Bernard. 2001. Se Nourrir au Quotidien en Nouvelle-France. Sainte-Foy: Les Éditions GID.

Auer, Raphael. 2013. "Geography, institutions, and the making of comparative development", Journal of Economic Growth, Vol.18, no.2, pp.179-215.

Baillargeon, Noël. 1977. Le Séminaire de Québec de 1685 à 1760. Québec : Presses de l'Université Laval.

Bairoch, Paul. 1989. "Wages as an Indicator of Gross National Product" in eds. Peter Scholliers, Real Wages in $19^{\text {th }}$ and $20^{\text {th }}$ century Europe: Historical and Comparative Perspectives. New York: Berg Publishing, pp.51-60.

Balassa, Bela. 1964. "The Purchasing-Power Parity Doctrine: A Reappraisal”, Journal of Political Economy, Vol. 72, no.6, pp.584-596.

Baten, Joerg, Debin Ma, Stephen Morgan and Qing Wang. 2010. "Evolution of living standards and human capital in China in the $18^{\text {th }}-20^{\text {th }}$ centuries: Evidences from real wages, ageheaping and anthropometrics", Explorations in Economic History, Vol.47, No.3, pp.347359.

Barthe, Jessica. 2015. L'Administration seigneuriale derrière la clôture : les Ursulines de Québec et la seigneurie de Sainte-Croix. MA thesis, department of history, Université de Sherbrooke.

Baumgarten, Linda. 2002. What Clothes Reveal: The Language of Clothing in Colonial and Federal America. New Haven, CT: Yale University Press.

Bédard, Éric. 2012. L'histoire du Québec pour les nuls. Montréal : First Editions.

Bernier, Gérald. 1981. "Sur quelques effets de la rupture structurelle engendrée par la Conquête au Québec : 1760-1854" Revue d'histoire de l'Amérique française, Vol.35, no.1, pp.69-95.

Bernier, Gérald and Daniel Salée. 1994. Entre l'ordre et la liberté : colonialisme, pouvoir et transition vers le capitalisme dans le Québec du XIXe siècle. Montréal : Boréal.

Bessières, Arnaud. 2008. "Le salaire des domestiques au Canada au XVIIe siècle" Histoire, économie \& société Vol.27, no. 4, pp. 33-50. 
Bhagwati, Jagdish. 1984. "Why are services cheaper in the poor countries?" Economic Journal, Vol. 94, no. 374, pp. 279-286.

Board of Historical Publications. 1933. Documents Relating to Currency, Exchange and Finance in Nova Scotia with Prefatory Documents. Ottawa: Public Archives of Canada.

de Boor, Carl. 2001. A Practical Guide to Splines (Revised Edition), New York: Springer.

Bosc, Ernest. 1883. Dictionnaire raisonné d'architecture, Tome premier. Paris : Librairie de Firmin-Didot et Cie.

Boleda, Mario. 1983. Les Migrations au Canada sous le régime Français. $\mathrm{PhD}$ thesis, department of History at the Université de Montréal.

Bordo, Michael, Angela Redish and Hugh Rockoff. 2015. "Why didn't Canada have a banking crisis in 2008 (or in 1930, or 1907, or ...)?” Economic History Review, Vol.68, no.1, pp.218243.

Boserup, Esther. 1965[2008]. The Conditions of Agricultural Growth: The Economics of Agrarian Change under Population Pressure. New Brunswick, NJ: Aldine Transactions.

Bradbury, Mason, Nils Peterson and Jianguo Liu. 2014. "Long-term dynamics of household size and their environmental implications", Population and Environment, Vol. 36, no.1, pp.7384.

Breckenridge, Roeliff Morton. 1893. “The Paper Currencies of New France” Journal of Political Economy, Vol.1, No.3, p.407-410.

Briffa, K, P.D. Jones and F.H. Schweingruber. 1994. "Summer temperatures across northern North America: regional reconstructions from 1760 using tree-ring densities." Journal of geophysical research, vol.99, no.D12, pp.25835-25844.

Broadberry, Stephen and Bishnupriya Gupta. 2006. "The Early Modern Great Divergence: Wages, Prices and Economic Development in Europe and Asia, 1500-1800”, Economic History Review, Vol.59, no.1, pp.2-31.

Broadberry, Stephen, Bruce M.S. Campbell, Alexander Klein, Mark Overton and Bas van Leeuwen. 2015. British Economic Growth, 1270-1870. Cambridge: Cambridge University Press.

Buckley, Kenneth. 1958. "The role of staple industries in Canada's economic development." The Journal of Economic History, Vol.18, no.4, pp. 439-450. 
Burton, F.W. 1936. “The Wheat Supply of New France” Proceeding and Transactions of the Royal Society of Canada, Vol.30, pp.137-150.

Carlos, Ann and Frank Lewis. 2010. Commerce by a Frozen Sea: Native Americans and the European Fur Trade. Philadelphia, PA : University of Pennsylvania Press.

Carson, Jamie. 2002. Family Spending Power. Ottawa: Statistics Canada.

Chabat, Pierre. 1881. Dictionnaire des termes employés dans la construction, volume II. Paris: V.E Morel et Cie Éditeurs.

Chambers, Edward and Donald Gordon. 1966. "Primary products and economic growth: an empirical measurement" Journal of Political Economy, Vol. 74, no.4, pp.315-332.

Charbonneau, Hubert and Normand Robert. 1991. "The French Origins of the Canadian Population, 1608-1760" in Concise Historical Atlas of Canada eds. William Dean, Conrad Heidenrich, Thomas McIlwraith and John Warkentin, Toronto: University of Toronto Press, plate 34 .

Charbonneau, Hubert, Bertrand Desjardins, Jacques Légaré and Hubert Denis. 2000. “The Population of the St-Lawrence Valley, 1608-1760", in eds. Michael Haines and Richard Steckel, A Population History of North America. Cambridge: Cambridge University Press, pp.99-142.

Citron, Constance and Robert T. Michael (eds). 1995. Measuring Poverty: A New Approach. Washington D.C.: National Academy Press.

Clark, Gregory. 2005. "The condition of the working class in England, 1209-2004", Journal of Political Economy, vol.113, no.6, pp.1307-1340.

Cole, Arthur H. 1938. Wholesale Commodity Prices in the United States, 1700 -1861, Statistical Supplement, Actual Wholesale Prices of Various Commodities. Cambridge, MA: Harvard University Press.

Cole, Arthur H. 1970. "The Mystery of Fuel Wood Marketing in the United States", Business History Review, Vol.44, no.3, pp.339-359.

Courville, Serge. 1983. "Rente déclarée payée sur la censive de 90 arpents au recensement nominative de 1831 : méthodologie d'une recherche", Cahiers de géographie du Québec, Vol. 27, No. 70, pp.43-61.

Courville, Serge. 1990. Entre Ville et Campagne : l'essor du village dans les seigneuries du BasCanada. Québec : Presses de 1'Université Laval. 
Courville, Serge. 2008. Quebec: A Historical Geography. Vancouver: University of British Columbia Press.

Courville, Serge, Jean-Claude Robert and Normand Séguin. 1995. Le pays laurentien au XIXe siècle : les morphologies de base. Québec : Les Presses de l’Université Laval.

Crafts, Nicholas and Knick Harley. 1992. "Output growth and the British industrial revolution: a restatement of the Crafts-Harley view." The Economic History Review, Vol.45, no. 4, pp. 703-730.

Crandall, Ruth. 1934. "Wholesale Commodity Prices in Boston during the Eighteenth Century", Review of Economics and Statistics, Vol.16, no.6, pp.117-128.

Cranfield, John and Kris Inwood. 2007. "The great transformation: a long-run perspective on physical well-being in Canada", Economics \& Human Biology, Vol.5, no. 2, pp.204-228.

Curtis, Bruce. 2002. The Politics of Population: State Formation, Statistics, and the Census of Canada, 1840 to 1875. Toronto: University of Toronto Press.

Cvrcek, Tomas. 2013. "Wages, Prices and Living Standards in the Habsburg Empire, 1827-1910”, Journal of Economic History, Vol. 73, no.1, pp.1-37.

David, Paul. 1967. "New light on a statistical dark age: US real product growth before 1840", American Economic Review, Vol. 57, no.2, pp.294-306.

David, Paul and Peter Solar. 1977. "A Bicentenary Contribution to the History of the Cost of Living in America", Research in Economic History, Vol.2, pp.1-81.

Davis, Lance and Stanley Engerman. 1999. "The Economy of British North America: Miles Traveled, Miles Still to Go" The William and Mary Quarterly, Vol.56, no.1, pp.9-22.

Davis, Lewis. 2008. "Scale effects in growth: A role for institutions", Journal of Economic Behavior \& Organization, Vol.66, No. 2, 403-419.

Deaton, Angus and John Muellbauer. 1980 [2009]. Economics and Consumer Behavior. Cambridge: Cambridge University Press.

Dechêne, Louise. 1974. Habitants et Marchands de Montréal au XVIIe siècle. Paris : Plon.

Dechêne, Louise. 1986. "Observations sur l'agriculture du Bas-Canada au début du XIXe siècle" in Évolution et Éclatement du Monde Rural, France-Québec XVII-XXè siècles eds. Joseph Goy and Jean-Pierre Wallot, Paris and Montréal : Presses de 1'Université de Montréal and Éditions de l’École des Hautes Études en Sciences Sociales, pp.189-202. 
Dechêne, Louise.1994. Le Partage des Subsistances au Canada sous le Régime Français. Montréal : Éditions Boréal.

Delâge, Denys. 1970. "Les structures économiques de la Nouvelle-France et de la Nouvelle-York", Actualié économique, Vol.46, no.1, pp.67-118.

Dépatie, Sylvie. 1988. L'évolution d'une société rurale : l'Île Jésus au XVIIlème siècle. Montréal, $\mathrm{PhD}$ Thesis, Department of History, McGill University.

Dépatie, Sylvie. 2008. "Maîtres et domestiques dans les campagnes montréalaises au XVIIIe siècle : bilan préliminaire." Histoire, économie \& société Vol.27, No. 4, pp. 51-65

Desbarats, Catherine. 1992. "Agriculture within the Seigneurial Régime of Eighteenth Century Canada : Some Thoughts on the Recent Literature", Canadian Historical Review, Vol.73, no.1, pp.1-29.

Deschênes, Gilles. 2009. Quand le vent faisait tourner les moulins : Trois siècles de meunerie banale et marchande au Québec. Québec : Éditions du Septentrion.

Desloges, Yvon. 1991. A Tenant's Town : Quebec in the $18^{\text {th }}$ century. Ottawa: Parks Canada.

Dessureault, Christian. 2005. "L'évolution de la productivité agricole dans la plaine de Montréal, 1852-1871: grandes et petites exploitations dans un système familial d'agriculture." Social History/Histoire Sociale, vol.38, no.76, pp.235-265.

Dickinson, John. 1996. "New France : Law, Courts and Coutume de Paris, 1608-1760” Manitoba Law Review, Vol.23, no.1 pp.32-54.

Dobado-Gonzalez, Rafael. 2015. "Pre-Independence Spanish Americans: Poor, Short and Unequal ... or the Opposite", Revista de Historia Económica/Journal of Iberian and Latin American Economic History, Vol.33, no.1, pp.15-59

Dobado-Gonzalez, Rafael, and Héctor García-Montero 2014. "Neither So Low Nor So Short: Wages and Heights in Bourbon Spanish America from an International Comparative Perspective," Journal of Latin American Studies, Vol.46, no.2, pp.291-321.

Dudley, Leonard. 2008. Information Revolutions in the History of the West. London: Edward Elgar Publishing.

Dudley, Leonard. 2012. Mothers of Innovation: How Expanding Social Networks Gave Birth to the Industrial Revolution. Newcastle upon Tyne: Cambridge Scholars Publishing.

Dufour, Pierre. 1981. "La construction navale à Québec, 1760-1825: sources inexplorées et nouvelles perspectives de recherches." Revue d'histoire de l'Amérique française, vol. 35, no. 2, pp. 231-251. 
Ebeling, Dietrich. 1989. "Some Remarks on the Relationship between Overall Economic Output and Real Wages in the Pre-Industrial Period" in eds. Peter Scholliers, Real Wages in $19^{\text {th }}$ and $20^{\text {th }}$ century Europe: Historical and Comparative Perspectives. New York: Berg Publishing, pp.61-66.

Egnal, Marc. 1975. "The Economic Development of the Thirteen Continental Colonies, 1720 to 1775" William and Mary Quarterly, Vol.32, no.2, pp.191-222.

Egnal, Marc. 1996. Divergent Paths: How Culture and Institutions have shaped North American Growth. Oxford: Oxford University Press.

Egnal, Marc. 1998. New World Economies: The Growth of the Thirteen Colonies and Early Canada. Oxford: Oxford University Press.

Engerman, Stanley and Kenneth Sokoloff. 2002. Factor Endowments, Inequality, and Paths of Development among New World Economics. Cambridge, MA: National Bureau of Economic Research.

Feinstein, Charles. 1998. "Pessimism perpetuated: real wages and the standard of living in Britain during and after the Industrial Revolution", Journal of Economic History, Vol.58, no.3, pp.625-658.

Ferland, Catherine. 2010. Bacchus en Canada: Boissons, buveurs et ivresses en Nouvelle-France. Montréal: Éditions Septentrion.

Filion, Mario, Jean-Charles Fortin, Roland Viau and Pierre Lambert. 2000. Histoire du Haut SaintLaurent. Québec : Presses de l'Université Laval et Institut Québécois de Recherche sur la Culture.

Flandrin, Jean-Louis. 1979. Family in Former Times: Kinship, Household and Sexuality. Cambridge: Cambridge University Press.

Floud, Roderick, Robert Fogel, Bernard Harris and Sok Chul Hong. 2011. The Changing Body: Health, Nutrition and Human Development in the Western World since 1700. Cambridge, MA: National Bureau of Economic Research.

Fogel, Robert. 2004. The Escape from Hunger and Premature Death, 1700-2100: Europe, America and the Third World. Cambridge: Cambridge University Press

Fowles, Eileen. 2006. "What's a Pregnant Woman to Eat? A Review of Current USDA Dietary Guidelines and MyPyramid" The Journal of Perinatal Education, vol.15, no.4, pp.28-33. 
Frankema, Ewout and Marlous Van Waijenburg. 2012. "Structural impediments to African growth? New evidence for real wages in British Africa, 1880-1965", Journal of Economic History, Vol. 72, no.4, pp.895-926.

Fréchet, Guy, Pierre Lanctôt, Alexandre Morin and Frédéric Savard. 2010. Equivalence Scales: An Empirical Validation. Québec : Centre d'étude sur la pauvreté et l'exclusion.

Frégault, Guy. 1969 [1990]. La civilisation de la Nouvelle-France, 1713-1744. Montréal : Éditions Fides.

Fyson, Donald. 1992. "Du pain au madère : L'alimentation à Montréal au début du XIXe siècle", Revue d'histoire de l'Amérique française, vol.46, no.1, p.67-90.

Fyson, Donald. 2012. "The Conquered and the Conqueror: The Mutual Adaptation of the Canadiens and the British in Quebec, 1759-1775" in eds. Phillip Bucker and John G.Reid, Revisting 1759: The Conquest of Canada in Historical Perspective. Toronto: University of Toronto Press, pp.190-217.

Fyson, Donald, and François Fenchel. 2014. "Prison registers, their possibilities and their pitfalls: the case of local prisons in nineteenth-century Quebec." The History of the Family ahead-ofprint.

Gadoury, Lorraine, Yves Landry and Hubert Charnonneau. 1985. "Démographie différentielle en Nouvelle-France : villes et campagnes", Revue d'histoire de l'Amérique française, Vol.38, no.3, p.357-378.

Garnier, B. 1986. "Problème de reproduction économique et sociale dans le bocage normand au XVIIIe siècle" in Évolution et Éclatement du Monde Rural, France-Québec XVII-XXè siècles eds. Joseph Goy and Jean-Pierre Wallot, Paris and Montréal : Presses de l'Université de Montréal and Éditions de l'École des Hautes Études en Sciences Sociales, p.121-140.

Geloso, Vincent. 2013. Du Grand Rattrapage au Déclin Tranquille : Une Histoire Économique du Québec de 1900 à nos jours. Montréal : Éditions Accent Grave.

Geloso, Vincent. 2013. Une perspective historique sur la productivité et le niveau de vie des Québécois-de 1870 à nos jours. Montréal: Centre for Prosperity and Productivity at HEC Montréal.

Geloso, Vincent. 2015. “Toleration and British Public Finances in Quebec, 1760-1775”, Essays in Economic and Business History, Vol.33, pp.51-80.

Geloso, Vincent and Vadim Kufenko. 2015. "Malthusian pressures: empirical evidence from a frontier economy”, Journal of Population Research, Vol.32, no.3-4, pp.263-283. 
Geloso, Vincent and Alexis Lacombe. 2016. "Why was flour of poor quality? The impact of seigneurial laws and price controls on flour in Quebec during the colonial era", Agricultural History Review, Vol.64, no.2, pp.181-195.

Gentil, Marilyn. 2009. Les Niveaux et les Facteurs Déterminants de la Mortalité Infantile en Nouvelle-France et au début du Régime Anglais (1621-1779). PhD thesis, department of demography, Université de Montréal.

Gerschenkron, Alexander. 1947. "The Soviet Indices of Industrial Production", Review of Economics and Statistics, Vol.29, No.4, pp.217-226.

Girard, Jacques. 1959. "Les industries de transformation de la Nouvelle-France", Cahiers de géographie du Québec, Vol.3, no.6, pp.305-320.

Glaeser, Edward, Rafael La Porta, Florencio Lopez-de-Silanes and Andrei Shleifer. 2004. "Do institutions cause growth?", Journal of Economic Growth, Vol.9, no.3, pp.271-303.

Godfrey, Keith and David Barker. 2000. "Fetal nutrition and adult disease", American Journal of Clinical Nutrition, Vol.71, no.5, pp.1344-1352.

Gordon, Robert. 2005. "Technology in Colonial North America" in A Companion to American Technology eds. Carroll Pursell, Malden, MA: Blackwell Publishing, pp.9-31.

Gouvernement du Québec. 1926. Rapport de l'Archiviste de la Province de Québec pour 1925-6. Québec : Bureau de l'archiviste.

Gouvernement du Québec. 1947. Rapport de l'Archiviste de la Province de Québec pour 1946. Québec: Bureau de l'archiviste.

Government of the Province of Canada (1853). Census of the Canadas, 1851-1852, Volume I. Quebec: John Lowell Printer.

Gousse, Suzanne. 2009. Les couturières en Nouvelle-France : leur contribution socioéconomique à une société coloniale d'Ancien Régime. MA thesis, department of history, Université de Montréal.

Gray, Edward, Frank Consolazio and Robert M. Kark. 1951. "Nutritional Requirements for Men at Work in Cold, Temperate and Hot Environments", Journal of Applied Physiology, Vol.4, No.4, pp.270-275.

Green, Alan. 1969. "Regional Inequality, Structural Change, and Economic Growth in Canada. 1890-1956", Economic Development and Cultural Change, Vol.17, no.4, pp.567-583.

Greer, Allan. 1981. "Fur Trade Labour and Lower Canadian Agrarian Structures", Historical Papers / Communications historiques, Vol.16, no.1, pp.197-214. 
Greer, Allan. 1985. Peasant, Lord and Merchant: Rural Society in Three Quebec Parishes, 17401840. Toronto: University of Toronto Press.

Greer, Allan. 1997. The People of New France. Toronto: University of Toronto Press.

Greer, Allan. 2000. Habitants, Marchands et Seigneurs : la Société Rurale du Bas Richelieu, 17401840. Montréal : Éditions Septentrion.

Grenier, Benoît. 2007. Seigneurs Campagnards de la Nouvelle-France : Présence seigneuriale et sociabilité rurale dans la vallée du Saint-Laurent à l'époque préindustrielle. Rennes : Presses Universitaires de Rennes.

Groulx, Lionel. 1958. Notre Grande Aventure : l'empire Français en Amérique du Nord, 15351760. Montréal: Éditions Fides.

Gwyn, Julian. 1998. Excessive Expectations: Maritime Commerce \& the Economic Development of Nova Scotia, 1740-1870. Montréal and Kingston: McGill-Queen's University Press.

Hamelin, Jean. 1960. Économie et Société en Nouvelle-France. Québec : Presses de l'Université Laval.

Hanauer, Charles Auguste. 1878. Études économiques sur l'Alsace ancienne et moderne (denrées et salaires). Paris : Société industrielle de Mulhouse.

Hanauer, Charles Auguste. 1908. Autobiographie. Colmar, A.M.P Ingold.

Hamilton, Earl. 1944. "Use and misuse of price history", Journal of Economic History, Vol.4, no. S1, pp.47-60.

Hamilton, Gillian. 1999. "Property rights and transaction costs in marriage: Evidence from prenuptial contracts", Journal of Economic History, Vol.59, no.1, pp.68-103.

Hanson Jones, Alice 1980. Wealth of a Nation to Be. New York: Columbia University Press.

Hardy, Jean-Pierre. 1983. "Niveaux de richesse et intérieurs domestiques dans le quartier de SaintRoch à Québec, 1820-1850." Material Culture Review/Revue de la culture matérielle, Vol.17, pp.63-94.

Harris, Cole. 2012. Le Pays Revêche : Société, espace et environnement au Canada avant la Confédération. Québec: Les Presses de 1'Université Laval

Harris, Richard. 1966 [1984]. The Seigneurial System in Early Canada. Montréal: McGill-Queen's University. 
Hatcher, John and Mark Bailey. 2001. Modelling the Middle Ages: The History and Theory of England's Economic Development. Oxford: Oxford University Press.

Hinton, Michael and Vincent Geloso. 2015. "The Emperor has no clothes: a new price index for Canada, 1870-1900", Conference paper presented at the Canadian Economics Association on May $28^{\text {th }} 2015$.

Hoffman, Philip. 1996. Growth in a Traditional Society: The French Countryside, 1450-1815. Princeton, NJ: Princeton University Press.

Hoffman, Philip, David S. Jacks, Patricia Levin and Peter Lindert. 2002. "Real inequality in Europe since 1500”, Journal of Economic History, Vol.62, no.2, pp.322-355.

House of Assembly of Lower Canada. 1824. Appendix to the Journal of the House of Assembly of Lower Canada. Québec: House of Assembly of Lower Canada, Appendix R.

House of Assembly of Lower Canada. 1832. Appendix to the Journal of the House of Assembly of Lower Canada. Québec: Neilson and Cowan, Appendix U

House of Assembly of Lower Canada. 1832. Appendix to the Journal of the House of Assembly of Lower Canada. Québec: Neilson and Cowan, Appendix OO.

House of Assembly of Lower Canada. 1835. Appendix to the Journal of the House of Assembly of Lower Canada. Québec: P.G. Desbarats, Appendix KK.

Horovitz, William Bela. 1967. An Index of Retail Market Prices at Montreal, 1843-1867. Montreal, MA Thesis, Department of Economics, McGill University.

Houle, Daniel, Jean David Moore et Jean Provencher. 2007. « Ice bridges on the St-Lawrence River as an index of winter severity from 1620 to $1910 »$ Journal of Climate, vol.20, no.4, pp.757-764.

Humphries, Jane. 2013. "The lure of aggregates and the pitfalls of the patriarchal perspective: a critique of the high wage economy interpretation of the British industrial revolution", Economic History Review, Vol. 66, no.3, pp.693-714.

Humphries, Jane, and Jacob Weisdorf. 2016. Unreal Wages: A New Empirical Foundation for the Study of Living Standards and Economic Growth in England, 1260-1860. Oxford: Working Paper no. 147 of the Discussion Papers in Economic and Social History at the University of Oxford.

Innis, Harold. 1930 [1999]. The Fur Trade in Canada. Toronto: University of Toronto Press. 
Inwood, Kris and Jim Irwin. 2002. "Land, income and regional inequality: New estimates of provincial incomes and growth in Canada, 1871-1891", Acadiensis, Vol.31, no.2, pp.157184.

Jaenen, Cornelius. 1976. The Role of the Church in New France. Toronto: McGraw Hill.

Jones, Charles. 1995. "Time Series Tests of Endogenous Growth Models", Quarterly Journal of Economics, Vol.110, No.2, pp.495-525.

Jones, Peter J.H. and Ian K.K. Lee. 1996. "Macronutrient Requirements for Work in Cold Environments" in eds. Bernadette M. Marriott and Sydne J. Carlson, Nutritional Needs in Cold and High-Altitude Environments: Applications for Military and Field Operations. Washington D.C.: Committee on Military Nutrition Research, Institute for Medicine, pp.189-202.

Keane, Michael P. 2011. "Labor supply and taxes: a survey", Journal of Economic Literature, Vol.49, no.4, pp.961-1075.

Kesteman, Jean-Pierre, Peter Southam and Diane Saint-Pierre. 1998. Histoire des Cantons de l'Est. Québec : Presses de l'Université Laval

Komlos, John. 1994. "The height of Runaway Slaves in Colonial America" in Stature, Living Standards and Economic Development: Essays in Anthropometric history eds. John Komlos, Chicago: University of Chicago Press, pp. 93-116.

Kunitz, Stanley. 1984. "Mortality change in America, 1620-1920”, Human Biology, Vol.56, no.3, pp.559-582.

Lachance, André. 2000. Vivre, Aimer et Mourrir en Nouvelle-France : La Vie Quotidienne au XVIIe et XVIIIe siècles. Montréal : Éditions Libre Expression.

Lalou, Richard and Mario Boleda. 1988. "Une source en friche : les dénombrements sous le Régime français", Revue d'histoire de l'Amérique française, Vol.42, no.1, pp.47-72.

Lambert, Serge. 2001. Entre la crainte et la compassion : les pauvres à Québec au temps de la Nouvelle-France. Sainte-Foy, Les Éditions GID.

Landry, Yves. 1975. "Étude critique du recensement du Canada de 1765”, Revue d'histoire de l'Amérique française, Vol.29, no.3, pp.323-351.

Langlois Georges. 1935. Histoire de la Population Canadienne-Française. Montréal : Éditions Albert Lévesque. 
Lavertue, Robert. 1984. "L'histoire de l'agriculture Québécoise au XIXe siècle : une schématisation des faits et des interprétations", Cahiers de géographie du Québec, Vol.28, no.73-74, pp.275-287.

Legislative Council of Lower Canada. 1826. Appendix to Journal of the Legislative Council of Lower Canada. Québec: T.Cary and G.Desbarats, Appendix II.

Legislative Council of Lower Canada. 1832. Appendix to Journal of the Legislative Council of Lower Canada. Québec: T.Cary and G.Desbarats.

Le Goff, T.J.A. 1974. "The Agricultural Crisis in Lower Canada, 1802-12: A Review of a Controversy" Canadian Historical Review, Vol.55, no.1, pp.1-31.

Lemon, James. 1972. The Best Poor Man's Country: a Geographical Study of Early Southeastern Pennsylvania. Washington D.C.: Johns Hopkins University Press.

Levitt, Clint and Herbert Emery. 2002. "Cost of Living, real wages and real incomes in thirteen Canadian cities, 1900 -1950” Canadian Journal of Economics, Vol.35, no.1, pp.115-137.

Lewis, Frank and Marvin McInnis. 1980. "The Efficiency of the French-Canadian Farmer in the Nineteenth Century", Journal of Economic History, Vol.40, No.3, pp.497-514

Lewis, Frank and Marvin McInnis. 1984. "Agricultural Output and Efficiency in Lower Canada, 1851”, Research in Economic History, Vol.9, pp.45-87.

Lewis, Frank. 2001. "Farm Settlement with Imperfect Capital Markets: A Life-Cycle Application to Upper Canada, 1826-1851”, Canadian Journal of Economics, Vol.34, No.1, pp.174-195.

Library and Archives Canada. 1991. Fonds Paquet-Wallot: Projet de Recherche sur la Culture Matérielle et Société au Québec, 1792-1835. MG 31 D227.

Lindert, Peter. 2000. "When did inequality rise in Britain and America", Journal of Income Distribution, Vol.9, no.1, pp.11-25.

Lindert, Peter. 2016. Purchasing Power Disparity before 1914. Cambridge, MA: National Bureau of Economic Research.

Lindert, Peter and Jeffrey Williamson. 2013. "American Incomes Before and After the Revolution”, Journal of Economic History, Vol.73, No.3, pp.725-765.

Lindert, Peter and Jeffrey Williamson. 2014. American Colonial Incomes, 1650-1774. Cambridge, MA: National Bureau of Economic Research.

Lindert, Peter and Jeffrey Williamson. 2016. Unequal Gains: American Growth and Inequality since 1700. Princeton, NJ: Princeton University Press. 
Little, Jack. 1989. Ethno-Cultural Transition and Regional Identity in the Eastern Townships of Quebec. Ottawa: Canadian Historical Society.

Ljungqvist, Lars and Thomas Sargent. 2011. “A Labor Supply Elasticity Accord?” American Economic Review, Vol.101, no.3, pp.487-491.

Lower, Arthur R.M. 1946 [1957]. Colony to Nation: A History of Canada. Toronto, London and New York: Longmans, Green \& Company.

Lower, Arthur R.M. 1973. Great Britain's Woodyard : British America and the Timber Trade, 1763 to 1867. Montreal and Kingston: McGill-Queen's University Press.

Lucas, Robert. 1993. "Making a miracle”, Econometrica. Vol.61, no.2, pp.251-272.

Lunn, Alice Jean. 1939. "The Illegal Fur Trade out of New France, 1713-1760", Report of the Annual Meeting of the Canadian Historical Association, Vol.18, no.1, pp.61-76.

Lunn, Alice Jean. 1986 (1942). Développement économique de la Nouvelle-France, 1713-1760. Montréal: Presses de l'Université de Montréal.

Lydon, James. 2008. Fish and Flour for Gold, 1600-1800: Southern Europe in the Colonial Balance of Payments. Philadelphia, PA: Library Company of Philadelphia.

Maddison, Angus. 2003. The World Economy: Historical Statistics. Paris: Organisation for Economic Cooperation and Development (OECD).

Magra, Christopher. 2006. The New England Cod Fishing Industry and Maritime Dimensions of the American Revolution. Pittsburgh, PA, PhD Thesis, Department of History, University of Pittsburgh

Main, Gloria. 1994. "Gender, Work and Wages in Colonial New England", William \& Mary Quarterly, Vol.51, no.1, pp.39-66.

Main, Gloria and Jackson Main. 1988. "Economic Growth and the Standard of Living in Southern New England, 1640-1774" Journal of Economic History, Vol.48, no.1, pp.27-46.

Malanima, Paolo. 2013. "When did England overtake Italy? Medieval and early modern divergence in prices and wages." European Review of Economic History, Vol. 17, no. 1, pp. 45-70.

Mancall, Peter and Thomas Weiss. 1999. "Was Economic Growth Likely in Colonial British North America” Journal of Economic History, Vol.59, no.1, pp.17-40. 
Mann, M.E., R.S. Bradley., and M.K. Hughes. 1998. "Global-scale temperature patterns and climate forcing over the past six centuries”. Nature, Vol.392, No. 6678, pp.779-787

Martin, Paul-Louis. 2002. Les Fruits du Québec : histoire et traditions des douceurs de la table. Montréal : Éditions Septentrion.

Mathieu, Jacques. 1972. "La balance commercial : Nouvelle-France-Antilles au XVIIIe siècle", Revue d'histoire de l'Amérique française, Vol.25, no.4, pp.465-497.

Mathieu, Jacques. 2001. La Nouvelle-France : les Français en Amérique du Nord, XVIe-XVIIIe siècle. Québec: Presses de l’Université Laval.

Marr, William and Donald Paterson. 1980. Canada: An Economic History. Toronto: Gage Publishing.

Mayhew, Nick. Forthcoming. "Money in England from the middle ages to the nineteenth century" in Coins, Currency and Crisis, London: Routledge Press, pages undetermined.

McCalla, Douglass. 1985. "The Internal Economy of Upper Canada: New Evidence on Agricultural Marketing Before 1850”, Agricultural History, Vol.59, no.3, pp. 397-416.

McCallum, John. 1980. Unequal Beginnings: Agriculture and Economic Development in Quebec and Ontario until 1870. Toronto: University of Toronto Press.

McCann, Paul. 1983. Quebec's Balance of Payments, 1768-1772: A Quantitative Model. M.A. Thesis, Department of History, University of Ottawa.

McCullough, A.Bruce. 1990. Money and Exchange in Canada to 1900. Toronto: Dundurn Limited Press.

McCusker, John 1970. "The Rum Trade and the Balance of Payments of the Thirteen Continental Colonies", Journal of Economic Histoy, Vol.30, no.1, pp.244-247

McCusker, John. 1992. How Much Is That in Real Money? : A Historical Price Index for Use as a Deflator of Money Values in the Economy of the United States. Worcester, MA: American Antiquarian Society

McCusker, John. 2000. "Estimating Early American Gross Domestic Product", Historical Methods: A Journal of Quantitative and Interdisciplinary History, Vol. 33, no.3, pp. 155162.

McCusker, John and Russell Menard. 1985 [1991].The Economy of British America, 1607-1789. Chapel Hill, NC: University of North Carolina Press. 
McInnis, Marvin. 1981. "Some Pitfalls in the 1851-1852 Census of Agriculture of Lower Canada", Social History / Histoire Sociale, vol.14, no.27, pp.219-231.

McIntyre, Steve and Ross McKitrick. 2003. "Corrections to the Mann et. al.(1998) proxy data base and northern hemispheric average temperature series" Energy \& environment, Vol.14, no.6, pp.751-771.

McLean, Ian. 2013. Why Australia Prospered: The Shifting Sources of Economic Growth. Princeton NJ: Princeton University Press.

McMahon, Sarah. 1985. "A comfortable subsistence: the changing composition of diet in Rural New England”, William \& Mary Quarterly, Vol. 42, no.1, pp.26-65.

Meredith, David and Deborah Oxley. 2014. "Nutrition and health, 1700-1870" in eds. Roderick Floud, Jane Humphries and Paul Johnson, The Cambridge Economic History of Modern Britain, Vol.1, 1700-1870. Cambridge: Cambridge University Press.

Milanovic, Branko. 2006. "An estimate of average income and inequality in Byzantium around year 1000", Review of Income and Wealth, Vol.52, no.3, pp.449-470.

Minns, Chris and Mary McKinnon. 2007. "The costs of doing hard time: a penitentiary-based regional price index for Canada, 1883-1923”, Canadian Journal of Economics, Vol.40, no.2, pp.528-560.

Mitchell, Wesley. 1921. Index Numbers of Wholesale Prices in the United States and Foreign Countries. Washington D.C.: Bureau of Labor Statistics

Mironov, Boris. 2012. The Standard of Living and Revolutions in Russia, 1700-1917. London: Routledge.

Mokyr, Joel. 1990. Twenty-Five Centuries of Technological Change. London: Routledge Publishing.

Monière, Denis. 1976. "L'utilité du concept de mode de production des petits producteurs pour l'historiographie de la Nouvelle-France", Revue d'histoire de l'Amérique française, Vol.29, no.4, pp.483-502.

Moogk, Peter. 1971. “Apprenticeship indentures: A key to Artisan life in New France” Historical Papers / Communications Historiques, Vol.6, No.1, pp.65-83.

Moogk, Peter. 1989. "Reluctant Exiles: Emigrants from France in Canada before 1760", William \& Mary Quarterly, Vol.46, no.3, pp.463-505.

Mousette, Marcel. 1983. Le chauffage domestique au Canada : des origines à l'industrialisation. Québec: Presses de 1’Université Laval. 
Morgan, Kelly. 1997. “The Dynamics of Smithian Growth”, Quarterly Journal of Economics, Vol.112, No.3, pp.939-964.

Moriceau, Jean-Marc. 1994. Les fermiers de l'Île-de-France : XVe-XVIIIe siècle. Paris: Fayard.

Muldrew, Craig. 2011. Food, Energy and the Creation of Industriousness: Work and Material Culture in Agrarian England, 1550-1780. Cambridge: Cambridge University Press.

Nash, Gary B. 1979. Urban Crucible: Social Change, Political Consciousness, and the Origins of the American Revolution. Cambridge, MA : Harvard University Press.

Nish, Cameron. 1968. Les bourgeois-gentilshommes de la Nouvelle-France, 1729-1748. Montréal: Fides.

No author specified. 1820. The Emigrant's guide to the British settlements in Upper Canada and the United States of America. London: T. Keys.

No author specified. 1833. Present state of the Canadas: containing practical and statistical infortmation respecting the climate, soil, produce, agriculture, trade, currency, banking \&c., of Upper and Lower Canada, useful for the emigrant, merchant and Tourist. London: G.Herbert Publishing.

Noël, Françoise. 1992. Christie Seigneuries: Estate Management and Settlement in the Upper Richelieu Valley, 1760-1854. Montreal and Kingston: McGill-Queen's University Press,

Norton, Susan. 1971. "Population growth in colonial America: A study of Ipswich, Massachusetts", Population Studies, Vol.25, no.3, pp.433-452.

Ogilvie, Sheilagh and A.W. Carus. 2014. "Institutions and Economic Growth in Historical Perspectives", in eds Philippe Aghion and Steven Durlauf, Handbook of Economic Growth, Vol 2A. New York, NY: North Holland, pp. 403-513.

Organization for Economic Cooperation and Development. Undated. What Are Equivalence Scales? Paris: OECD.

Ouellet, Fernand. 1966. Histoire économique et sociale du Québec, 1760 à 1850. Ottawa : Édition Fides.

Ouellet, Fernand.1972. Élements d'histoire sociale du Bas-Canada. Montréal : Hurtubise HMH.

Ouellet, Fernand, Jean Hamelin and Richard Chabot. 1982. "Les prix agricoles dans les villes et les campagnes du Québec d'avant 1850 : aperçus quantitatifs" Histoire Sociale / Social History, vol. 15, no. 29, pp. 83-128. 
Paquet, Gilles and Jean-Pierre Wallot. 1998. “Some Price Indexes for Quebec and Montréal (17601913)”, Histoire Sociale / Social History, vol.31, no.62, pp.281-320.

Paquet, Gilles and Jean-Pierre Wallot. 2007. Un Québec Moderne, 1760-1840 : Essai d'histoire économique et social. Montréal : Éditions Hurtubise HMH.

Parlement de la Province du Canada. 1862. Documents de la Session : Première Session du Septième Parlement, Vol. XX. Québec: Hunter, Rose et Lemieux, unpaginated.

Paterson, Donald and Ronald Shearer. 2003. "A history of prices in Canada, 1840-1871: a new wholesale price index", Canadian Journal of Economics, Vol.36, no.1, pp.224-253.

Paul, Josianne. 2008. Exilés au nom du roi: les fils de famille et les faux-sauniers en NouvelleFrance, 1723-1749. Montréal : Éditions du Septentrion.

Pellett, Peter. 1990. "Food energy requirements in humans", The American Journal of Clinical Nutrition, vol. 51, no.5, p.711-722.

Percy, Michael and Rick Szostak. 1992. "The Political Economy of the Abolition of Seigneurial Tenure in Canada East", Explorations in Economic History, Vol.29, no.1, pp.51-68.

Phelps-Brown, E.H. \& Sheila Hopkins. 1956. "Seven Centuries of the Prices of Consumables, Compared with Builders’ Wage-Rates », Economica, Vol. 23, no 92, pp. 296-314.

Philipps, Paul. 1974. "Land Tenure and Economic Development: a comparison of Upper and Lower Canada", Journal of Canadian Studies, Vol. 9, No.2, pp.35-45.

Pomeranz, Kenneth. 2000. The Great Divergence: China, Europe, and the Making of the Modern World Economy. Princeton, NJ: Princeton University Press.

Public Archives of Canada. 1876. Censuses of Canada, 1665 to 1871, Vol. 4. Ottawa: Department of Agriculture.

Previant, Susan Lee and Peter Passell. 1979. A New Economic View of American History. New York: Norton.

Primack, Martin L. 1962. "Land clearing under nineteenth-century techniques: some preliminary calculations." Journal of Economic History, Vol.22, no. 04, pp.484-497.

Pritchard, James. 2007. In Search of Empire: The French in the Americas, 1670-1730. Cambridge: Cambridge University Press

Purvis, Thomas. 1999. Almanacs of American Life: Colonial America to 1763. New York, NY: Facts on File. 
Ravaillon, Martin. 2016. The Economics of Poverty: History, Measurement, and Policy. Oxford: Oxford University Press;

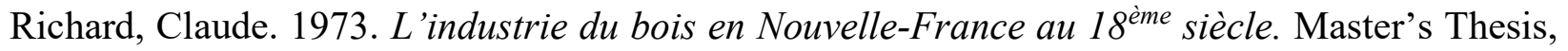
Department of History, University of Montreal.

Rodahl, Kaare. 1954. "Nutritional requirements in cold climates." Journal of Nutrition, vol. 53, no. 4 , pp. 575-588.

Rodrik, Dani. 1988. "Imperfect Competition, Scale Economies, and Trade Policy in Developing Countries", in Trade Policy Issues and Empirical Analysis, edited by Robert Baldwin, Chicago IL: University of Chicago Press, pp.109-144.

Rogoff, Kenneth. 1996. "The purchasing power parity puzzle", Journal of Economic Literature, Vol.34, no.2, pp.647-668.

Rousseau, François. 1983. L'œuvre de Chère en Nouvelle-France: Le régime des malades à l'hôtel-Dieu de Québec. Québec Presses de l'Université Laval.

Rosenbloom, Joshua and Thomas Weiss. 2012. "Economic Growth in the Mid-Atlantic region: Conjectural estimates for 1720 to 1800", Explorations in Economic History, Vol.51, No.1, pp.41-59

Rothenberg, Winifred. 1979. “A Price Index for Rural Massachusetts, 1750-1855” Journal of Economic History, Vol.39, no.4, pp.975-1001.

Rothenberg, Winifred. 1981. "The Market and Massachusetts Farmers, 1750-1855" Journal of Economic History, Vol. 41, no. 2, pp.283-314.

Ruddel, David Thierry. 1990. "Consumer Trends, Clothing, Textiles, and Equipment in the Montreal Area, 1792-1835." Material Culture Review/Revue de la culture matérielle Vol. 32 , no. 1, pp.45-64.

Russell, Peter. 2012. How Agriculture Made Canada: Farming in the Nineteenth Century. Montreal and Kingston: McGill-Queen's University Press.

de Sales La Terrière, Pierre. 1830. A Political and Historical Account of Lower Canada: With Remarks on the Present Situation of the People, as Regards Their Manners, Character Religion \&c \&c. London: William Marsh and Alfred Miller

Schneider, Eric. 2013. "Real Wages and the Family: Adjusting Real Wages to Changing Demography in Pre-Modern England", Explorations in Economic History, Vol.50, no.1, pp.99-115. 
Séguin, Maurice. 1947. "Le régime seigneurial au pays de Québec, 1760-1854 (1er article)." Revue d'histoire de l'Amérique française, Vol.1, no.3, pp.382-402.

Séguin, Maurice. 1971 [1946]. "La conquête et la vie économique des Canadiens" in eds. René Durocher and Paul-André Linteau, Le "Retard » du Québec et l'infériorité économique des Canadiens-Français. Montréal: Éditions Boréal Express, pp.93-111.

Selgin, George. 2010. "Central banks as sources of financial instability", Independent Review, Vol.14, no.4, pp.485-496.

Selgin, George, William D. Lastrapes and Lawrence H. White. 2012. "Has the Fed been a failure", Journal of Macroeconomics, Vol.34, no.3, pp.569-596.

Services des Transcriptions et Dérivés de la Radio. 1980. Émergence d'une colonie à deux versants. Montreal, Société Radio-Canada.

Sharp, Paul and Jacob Weisdorf. 2012. "French revolution or industrial revolution? A note on the contrasting experiences of England and France up to 1800", Cliometrica, Vol.6, No.1, pp.7988.

Shepherd, James and Gary Walton. 1972. Shipping, maritime trade, and the economic development of colonial North America. Cambridge: Cambridge University Press.

Shortt, Adam. 1913. "The Colony in its economic relations" in Canada and its provinces: a history of the Canadian people and their institutions by one hundred associates, vol.2, eds by Adam Shortt and Arthur Doughty, Edinburgh University Press.

Shortt, Adam. 1925. Documents Relating Canadian Currency, Exchange and Finance During the French Period, Selected and Edited with Notes and Introduction, Volume 1, Ottawa: Board of Historical Publications Canadian Archives.

Simon, Julian L. 1977. The Economics of Population Growth. Princeton, NJ: Princeton University Press.

Slonosky, Victoria. 2003. "The meteorological observations of Jean-François Gaultier, Québec, Canada: 1742-56" Journal of Climate, vol.16, no.13, pp.2232-2247.

Srivastava, K.K and Ratan Kumar. 1992. "Human Nutrition in cold and high terrestrial altitudes", International Journal of Biometrology, Vol.36, No.1, pp.10-13.

Steckel, Richard. 1999. "Nutritional Status in the Colonial American Economy", William \& Mary Quarterly, Vol.56, no.1, pp.31-52.

Stephenson, Judy. 2014. Gilboy revisited: or low(er) wages and the pre-industrial London building craftsman. Communication presented at the Economic History Society 2014 conference in Warwick 
Sylla, Richard. 2006. "Political Economy of Financial Development: Canada and the United States in the Mirror of the Other, 1790-1840." Enterprise and Society, Vol. 7, no. 4, pp. 653-665.

Tatarek, Nancy. 2006. "Geographical height variation among Ohio Caucasian male convicts born 1780-1849," Economics \& Human Biology, Vol.4, no.2, pp.222-236.

Thibeault, Richard. 1989. "Note de Recherche : Les unités de mesure dans les documents officiels du dix-neuvième siècle au Bas-Canada et au Québec.", Revue d'histoire de l'Amérique française, Vol.43, pp.221-232.

Tremblay, Robert. 1979. "La formation matérielle de la classe ouvrière à Montréal entre 1790 et 1830", Revue d'histoire de l'Amérique française, Vol.33, no.1, pp.39-50.

Trudel, Marcel. 1997. Histoire de la Nouvelle-France, Vol.IV : La Seigneurie de la Compagnie des Indes Occidentales, 1663-1674. Montreal: Éditions Fidès

Trudel, Marcel. 2004. Deux siècles d'esclavage au Québec. Montréal : Hurtubise.

Turvey, Ralph. 2010. The Cost of Living in London, 1740-1834. London: Department of Economic History at the London School of Economics and Political Science.

United States Deparment of Agriculture. 1997. Usual Planting and Harvesting Dates for U.S. Field Crops. Washington D.C.: National Agricultural Statistics Service at the USDA.

Urquhart, M.C. 1993. Gross National Product, Canada, 1870-1926: The Derivation of Estimates. Kingston : McGill-Queen's University Press.

Vallières, Marc, Yvon Desloges, Fernand Harvey, Andrée Héroux, Réginald Auger, SophieLaurence Lamontagne and André Charbonneau. 2008. Histoire de Québec et de sa région, Tome 1 : Des origines à 1791. Québec : Presses de 1'Université Laval.

Vanesse, Alfred Rowland. 1958. A Social History of the Seigniorial Regime in Canada, 17121739. PhD Thesis, Department of History, University of Montreal

Viau, Roland. 2012. "Pour qui souffle le vent ? Heur et malheur d'une entité coloniale, 1702-1760" in eds. Dany Fougères, Histoire de Montréal et de sa région, Tome 1, Des Origines à 1930. Québec: Presses de 1’Université Laval, pp.165-210.

Vickers, Daniel. 1994. Farmers and Fishermen: Two Centuries of Work in Essex County, Massachusetts, 1630-1850. Chapel Hill, NC: University of North Carolina Press.

Vickers, Daniel. 1996. “The Price of Fish: A Price Index for Cod, 1505-1892”, Acadiensis, Vol. 25, no. 2, pp.92-104.

de Vries, Jan. 2008. The Industrious Revolution: Consumer Behavior and the Household Economy, 1650 to the Present. Cambridge: Cambridge University Press. 
Young, Brian. 1986. In its corporate capacity: The Seminary of Montreal as a Business Institution, 1816-1876. Montreal and Kingston: McGill-Queen's University Press.

Young, Brian. 2012. Below the Academic Radar: Denis Vaugeois and Constructing the Conquest in the Quebec Popular Imagination" in eds. Phillip Bucker and John G.Reid, Remembering 1759: The Conquest of Canada in Historical Memory. Toronto: University of Toronto Press, pp.226-250.

Weedon, William Babcock. 1890 [2011]. Economic and Social History of New England, 16201789. London : British Library Historical Print Editions.

Wien, Thomas. 1990. "Les travaux pressants : calendrier agricole, assolement et productivité au Canada au XVIIIe siècle" Revue d'histoire de l'Amérique française, vol.43, no.4, pp.535558.

Wilson, Kax.1979. A History of Textiles. Boulder, CO: Westview Press.

World Bank. 1990. World Development Report. Washington D.C.: World Bank Group. 